São Paulo

2007

UNIVERSIDADE DE SÃO PAULO

FACULDADE DE FILOSOFIA, LETRAS E CIÊNCIAS HUMANAS DEPARTAMENTO DE LETRAS MODERNAS

PROGRAMA DE PÓS-GRADUAÇÃO EM LÍNGUA E LITERATURA ALEMÃ

\title{
O Íntimo e o Coletivo em Dois Mundos Diversos: Análise comparativa dos discursos utilizados em peças publicitárias alemãs e brasileiras
}

Clélia Barqueta

Tese apresentada ao Programa de PósGraduação em Língua e Literatura Alemã do Departamento de Letras Modernas da Faculdade de Filosofia, Letras e Ciências Humanas da Universidade de São Paulo, para obtenção do título de Doutora em Letras.

Orientadora: Prof ${ }^{a}$. Dra . Eva Maria Ferreira Glenk 
São Paulo

2007

\begin{abstract}
UNIVERSIDADE DE SÃO PAULO
FACULDADE DE FILOSOFIA, LETRAS E CIÊNCIAS HUMANAS DEPARTAMENTO DE LETRAS MODERNAS

PROGRAMA DE PÓS-GRADUAÇÃO EM LÍNGUA E LITERATURA ALEMÃ
\end{abstract}

O Íntimo e o Coletivo em Dois Mundos Diversos: Análise comparativa dos discursos utilizados em peças publicitárias alemãs e brasileiras

Clélia Barqueta 
São Paulo

2007

Aos meus pais, Hermenegildo e Olga, que me deram muito mais do que podiam dar.

A meu marido, Manoel Bione e a minha filha, Lara, que sempre estiveram juntos. 


\section{AGRADECIMENTOS}

\section{Agradeço}

a minha orientadora, Prof ${ }^{a}$. Dra ${ }^{\text {. }}$ Eva Maria Ferreira Glenk, cuja orientação foi fundamental, por ter me acompanhado nesse trajeto, aceito minhas mudanças de propostas de trabalho, confiado em mim durante essas mudanças e (sempre que possível) me mantido calma ao longo desse percurso;

aos professores, professoras e funcionárias do Programa de Pós-Graduação em Língua e Literatura Alemã da Universidade de São Paulo, pelo apoio obtido, especialmente à secretária Edite Mendes, sempre à disposição quando necessário;

ao Centro Cultural Brasil-Alemanha - CCBA -, de Recife, por ter disponibilizado espaço para a pesquisa de material, assim como pela possibilidade para confecção de cópias, quando necessárias;

ao Goethe-institut de São Paulo, por ter liberado material para uma pesquisa que, embora não tenha sido levada a cabo, por mudança de projeto, mantém-se arquivada para outras oportunidades;

às Prof ${ }^{a}$ s. Drํㅗㅇ. Masa Nomura e Lígia Fonseca Ferreira, por terem aceito a incumbência da avaliação do Exame de Qualificação;

à Prof ${ }^{a}$. Drª . Nelly Carvalho, minha orientadora do mestrado na UFPE;

ao Prof. e amigo Murilo Jardelino da Costa, pelo incentivo, pela troca de informações tão enriquecedoras, pela disponibilização de estadias em seu apartamento em São Paulo e pelas boas visitas aos tradicionais botecos paulistanos, que ninguém é de ferro;

à amiga Cristina Karter, por ter, gentilmente, me acolhido em seu apartamento;

às professoras e aos professores do Departamento de Letras Estrangeiras Modernas da UFPB-João Pessoa, que sempre me incentivaram a continuar em meus estudos e com os quais divido excelentes momentos na Universidade;

às Prof ${ }^{\mathrm{a}} \mathrm{s}$. Maria de Guadalupe e Rosângela Araújo, que aceitaram ser minhas procuradoras durante o tempo em que estive ausente;

à Prof ${ }^{a}$. Dra . Marta Pragana Dantas, minha assessora para assuntos imobiliários;

à Profa ${ }^{\text {. }}$ Dra . Maura R. Dourado, por ter lido os meus primeiros projetos para o Doutorado; 
a minha irmã Clayde e a suas filhas, por terem me recebido em sua casa, permitido que eu interferisse em suas rotinas familiares e com quem dividi ótimos momentos;

a minha mãe, Olga Contesini Barqueta, uma das mulheres mais inteligentes que conheço, por ter tido a paciência de me criar, até hoje;

a minha irmã Cláudia e família, pela acolhida em Atibaia;

ao meu marido Manoel Bione de Souza, que me ensinou a permissão de ser feliz, que faz do meu cotidiano uma festa e sem o qual esse trabalho não teria acontecido, tanto pelo seu incentivo como pelos conselhos maravilhosos, assim como pela paciente correção dos textos e, principalmente, pela sua descoberta de que é um excelente cozinheiro e com isso ter me alimentado física e intelectualmente, durante esse período, com conversas e massas maravilhosas;

a Lara, minha filha, por existir. 
"Não existe homem fracassado, o conceito de sucesso é que está errado."

\section{Charles Bukowsky}

"Tudo deve mudar, para que tudo continue o mesmo."

Tomasu de Lampedusa 


\section{RESUMO}

O objetivo deste trabalho é fazer uma análise comparativa entre os anúncios de publicidade das empresas BASF e PFIZER, veiculados nas revistas semanais VEJA (brasileira) e DER SPIEGEL (alemã) durante o ano de 2005, a fim de detectar diferenças e semelhanças entre os trabalhos elaborados para esses dois países. A peça publicitária será encarada como uma construção multimodal, cuja existência advém da interação dos vários elementos que a compõem. Espera-se, com esse estudo comparativo entre os mecanismos argumentativos, acionados pelas publicidades brasileira e alemã, desvendar um pouco mais os sentidos próprios dessas criações em cada um desses países. Será pesquisado: de que forma esses percursos argumentativos - visuais e lingüísticos - vão sendo montados nas peças publicitárias e quais sentidos buscam criar; com qual inventário perceptual os produtos ou serviços vão sendo ligados; quais elementos mitológicos são acionados, recriados, cultivados, estimulados em ambos os países, com o intuito de ancorar a marca na mente dos leitores. Será examinado, ainda, de que forma a transmissão de informações acerca do produto ou da marca reflete possíveis valores dos consumidores e da cultura na qual estão imersas. Em relação aos pressupostos teóricos, nos apoiaremos, principalmente, na Análise Crítica do Discurso, na teoria da Argumentação/Retórica de Aristóteles, Perelman e Spang, assim como em Kress; van Leeuwen e Dondis, para as análises visuais e em Jung, Campbell e Randazzo para as categorias mitológicas.

\section{PALAVRAS-CHAVES : Publicidade, Análise Crítica do Discurso, Retórica, Mitologias, Comparação de Anúncios}




\section{ABSTRACT}

This piece of research aims at making a comparative analysis between advertisements for the companies BASK and PFIZER found in the weekly magazines VEJA (Brazilian) and DER SPIEGEL (German) during the year 2005 in order to detect differences and similarities between the work produced for these two countries. The publicity piece will be considered to be a multimodal construction whose existence derives from the interaction of different elements. By comparing the argumentative mechanisms triggered by both Brazilian and German advertisements, we expect to reveal, a bit further, the meanings of these creations in each of these countries. The research will cover: how the argumentative paths both visual and linguistic - are built in advertising and which meanings they seek to create; which perceptual inventory the products or services are being linked to; which mythological elements are triggered, rebuilt, cultivated, motivated with the intention of anchoring the brand on the readers' minds. It will also be examined how the transmission of information about the product or the brand reflect customers' possible values and the culture in which they are immersed. In relation to the theoretical framework, the research will rely heavily on the Critical Discourse Analysis, the Theory of Argumentation/Aristotles' rhetoric, Perelman, Spang, as well as on Kress, van Leeuwen and Dondis, for the visual categories and on Campbell and Randazzo for the mythological categories.

Key-words: Advertising, Rhetoric, Critical Discourse Analysis, Mythology, Advertisement comparison 


\section{SUMÁRIO}

RESUMO

ABSTRACT............................................................................... 08

INTRODUÇÃO................................................................. 11

1. ANÁLISE CRÍTICA DO DISCURSO................................... 18

1.1. Concepção de língua................................................................... 18

1.2. Análise crítica do discurso........................................................ 33

1.3. Categorias de análise da ACD..................................................... 45

1.3.1. Categorias gramaticais.............................................................. 47

=> Operadores argumentativos...................................................... 47

=> Transformações sintáticas........................................................... 52

- Transformação passiva....................................................... 53

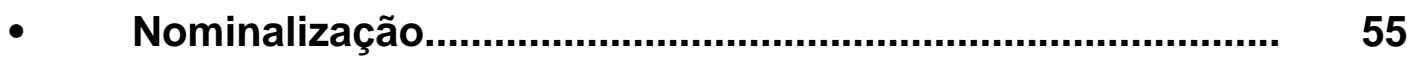

- Outras transformações......................................................... 57

1.3.2. Categorias semântico-pragmáticas.............................................. 58

$=>$ Ethos.................................................................................. 58

$=>$ Modalidade lingüística.................................................................... 63

=>Índice de avaliação lexical........................................................ 66

- Relexicalização................................................................... 67

- Palavras de plástico............................................................... 68

- Expressões fraseológicas. .................................................. $\quad 70$

=>Índices de polifonia................................................................

1.3.3. Categorias da linguagem visual................................................. 78

2. RETÓRICA E SEU USO NA PUBLICIDADE .................... 82

2.1. Retórica e sofistas....................................................................... 83

2.2. Retórica na história.................................................................... 88

2.3. Retórica e publicidade................................................................ 95 
3. PUBLICIDADE.................................................................... 110

3.1. O que é e para que serve ................................................................ 110

3.2. Estrutura e linguagem do anúncio publicitário.............................. 122

3.3. Cultura e comunicação de massas................................................. 132

3.4. A mola mestra da publicidade ..................................................... 137

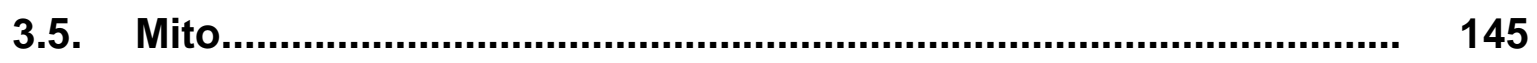

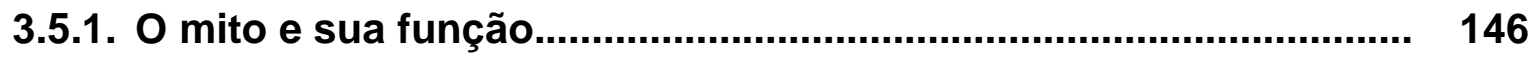

3.5.2. Mitologia na publicidade ............................................................ 154

4. PROCEDIMENTOS METODOLÓGICOS.............................. 158

5. ANÁLISE DE DADOS.................................................... 164

5.1. 1. Anúncio da BASF na Alemanha................................................. 166

5.2. 2. Anúncio da BASF na Alemanha............................................ 192

5.3. 3. Anúncio da BASF na Alemanha.................................................. 203

5.4. 1. Anúncio da BASF no Brasil...................................................... 217

5.5. 2. Anúncio da BASF no Brasil................................................... 236

5.6. Comparação entre as publicidades da BASF................................. 245

5.7. Anúncio da Pfizer na Alemanha.................................................... 255

5.8. 1. Anúncio Pfizer no Brasil......................................................... 271

5.9. 2. Anúncio Pfizer no Brasil.......................................................... 292

5.10 Comparação entre as publicidades da Pfizer................................. 299

6. CONSIDERAÇÕES GERAIS: O COLETIVO E O ÍNTIMO EM DOIS MUNDOS DIVERSOS...................................................... 305

7. REFERÊNCIAS BIBLIOGRÁFICAS.................................. 318

8. ANEXO 


\section{INTRODUÇÃO}

Atualmente, a publicidade tem um papel fundamental em nosso cotidiano. Presente em quase todos os ramos da atividade humana, ela mobiliza imensa soma de energia e de capital de empresas e governos. Funciona como veículo para a propagação tanto de produtos e serviços, como também de valores sociais e culturais. Pesquisar a linguagem publicitária é, também, uma maneira de analisar/descobrir atualizações e tendências dos movimentos sócio-culturais.

Sendo esse um tema muito polêmico, muito sobre ele já foi pesquisado. Portanto, este estudo não pretende esgotar o assunto, mas inseri-lo numa discussão mais ampla. Seu objetivo é focalizar a atenção não apenas nos níveis lingüísticos das línguas portuguesa e alemã, mas também na organização dos elementos visuais do anúncio.

Este trabalho se propõe a estudar a página do anúncio como um texto multimodal, isto é, um texto composto por mais de um sistema semiótico, no qual cada uma das linguagens que o compõe, age conjuntamente com as demais, potencializando a criação de sentidos.

Esses são fatores que integradamente colaboram para a veiculação de sentidos. Por intermédio da análise do funcionamento desses mecanismos, procuraremos detectar diferenças e semelhanças em alguns trabalhos publicitários no Brasil e na Alemanha.

Espera-se, com esse estudo comparativo entre os mecanismos argumentativos acionados pelas publicidades brasileira e alemã, compreender um pouco mais a respeito das criações de sentidos próprios dessas comunidades, respondendo às perguntas:

1- $\quad$ Como se expressam os percursos argumentativos lingüísticos e visuais que vão sendo montados nas peças publicitárias?

2- Que tipos de diferenças ou semelhanças ocorrem nas materializações lingüístico-visuais e com qual objetivo ocorrem dessa forma? 
3- Que elementos mitológicos vão sendo acionados, recriados ou estimulados nos anúncios dos dois países? E o que pode demonstrar isso?

4- $\quad$ De que forma a construção de sentidos em relação às características dos produtos ou das empresas que os fabricam reflete os valores dos consumidores e da cultura na qual estão imersos?

5- $\quad$ Serão esses valores absolutamente diferentes nos dois países em questão? Pouco diferentes? Semelhantes em muitos ou poucos pontos? Em que aspectos iguais?

6- De que forma os anúncios que chegam prontos ao público consumidor deixam perceber o que se admite como sendo acordado entre os seus interlocutores?

Ao se trabalhar com o texto multimodal, pode-se optar por duas formas de ação. A primeira seria a investigação separada de seus sentidos, a partir de cada sistema semiótico utilizado para compô-lo. Outra opção seria encarar esses sentidos como interligados, permanentemente interagindo e afetando-se uns aos outros. Neste trabalho, optamos pela segunda forma de ação. Embora em um primeiro momento, sejam feitas separadamente as análises da composição visual e depois da composição lingüística, em nenhum momento parte-se do pressuposto que os dois atuam separadamente sobre o leitor. Procura-se estudar a página do anúncio como um único texto, no qual nem o material verbal é o mais importante, nem o material visual é apenas uma ilustração do anúncio.

Os anúncios publicitários, escolhidos como corpus para este estudo, serão encarados como uma construção coesa, integrados por vários elementos que os compõem: o texto lingüístico, a imagem e o modo como esses elementos são organizados de forma a interagirem, potencializando os sentidos que procuram propagar. A separação desses elementos, que funcionam integradamente, será feita apenas por motivação metodológica. 
A página de inserção do anúncio também faz parte de um sistema semiótico. Tal abordagem, porém, não será tratada nesse trabalho.

Optou-se pela análise dos componentes visuais em primeiro lugar, por serem estes os que mais rapidamente são detectados pelo ser humano. Em publicidade, na maioria das vezes, a imagem é mais impactante que o próprio texto escrito, já que é 'lida' com maior rapidez. Ela se impõe como significação, já que tem função simbólica dentro do anúncio. Ao mesmo tempo, o texto, muitas vezes, funciona como elemento icônico, dando à publicidade um caráter de seriedade, apenas por sua presença, sem, necessariamente, levar-se em consideração o seu conteúdo.

Serão investigados como os diversos elementos da imagem e do material lingüístico são organizados de forma a tentar conduzir o leitor a uma possível e desejada leitura coerente do anúncio. Essa organização é parte do componente interpretacional e funciona como uma espécie de 'guia' do leitor. Sugere o percurso interpretativo a ser feito em direção a certas construções de sentidos, ao mesmo tempo em que procura impedir outras. São estas estratégias de organização desses elementos que nos interessam neste trabalho.

A escolha dos anúncios elaborados pela BASF e pela Pfizer deveu-se à forte presença dessas duas empresas, simultaneamente, no Brasil e na Alemanha. Além do fato de serem grandes anunciantes em diversos meios de comunicação, em ambos os países. Outra razão dessa escolha ocorreu em função do fato de que as duas empresas atuam em áreas bem diversas da vida humana. A primeira é responsável pela produção de insumos agrícolas, derivados de petróleo como tintas, plásticos etc. e produtos de rendimento ou performance, isto é, produtos que são úteis em outros ramos de atividades, tais como melhorar rendimento de motores e outros materiais.

Pelo que foi especificado acima, pode-se perceber que a BASF, além de produzir materiais que vende diretamente ao consumidor final, como CDs, isolantes térmicos etc., atua, também e principalmente, na esfera de infraestrutura, fornecendo materiais para outras indústrias, que os utilizam como componentes de seus produtos finais. Sua atuação, portanto, ocorre na esfera do 
coletivo, isto é, abrange um amplo campo de atuação, estando presente, direta ou indiretamente, na vida das coletividades.

Já a Pfizer fabrica produtos para a área de saúde. Produz medicamentos, entre eles, o Viagra, consumido pela população masculina para a melhoria de sua atividade sexual. São os anúncios desse produto que nos interessam nessa análise.

O medicamento Viagra está vinculado à esfera da sexualidade, que possui, segundo Freud (1974), vários aspectos considerados tabus. Ou seja, é um tema que está ligado ao mais íntimo de nosso ser e sobre o qual se evita falar de maneira clara e direta. Só ultimamente, tem-se tocado de forma mais clara nesse assunto, principalmente por causa do surgimento da Aids. Mesmo assim, as publicidades voltadas para a prevenção da doença utilizam as mais variadas metáforas. Dificilmente, encontraremos, por exemplo, um anúncio que diga claramente 'ao ter relações sexuais com um parceiro, do outro sexo ou não, ponha a camisinha, antes da penetração vaginal ou anal, a fim de evitar a Aids e outras doenças sexualmente transmissíveis.' A sexualidade, é, portanto, um dos últimos redutos da intimidade, da individualidade, num mundo cada vez mais coletivizado pelos meios de comunicação de massa, pela internet e seus orkuts etc.

Temos, assim, dois espectros a serem abrangidos pelos anúncios publicitários. Um, amplamente coletivo, e outro profundamente íntimo. O primeiro espectro é alvo dos produtos BASF, que chegam tanto aos consumidores individuais como a grandes corporações industriais que utilizam seus materiais como componentes a serem transformados em produtos finais, bem como a grandes plantações e criações de gados, que usam seus agrotóxicos e pesticidas, e, ainda, a governos, que usam outros produtos voltados para tratamento de mananciais. No outro extremo, temos o Viagra, que é um medicamento específico para o combate à disfunção erétil, ou seja, para melhorar o desempenho sexual do homem. Um produto bem pessoal, voltado para algo profundamente íntimo, que é $o$ ato sexual.

Dessa diferença de campos de atuação, pode-se concluir que serão necessários tipos de estratégias muito diversas para a abordagem do consumidor 
e, dessa forma, pode-se ter um amplo espectro de análise, que abrange tanto a esfera do coletivo como da sexualidade da comunidade, um dos últimos espaços a sofrer a intervenção da mercantilização e consequentemente da publicidade.

O primeiro capítulo será destinado a discutir alguns fundamentos teóricos da Análise Crítica do Discurso, que é parte do aparato teórico que embasa este trabalho. Nele, serão discutidos alguns aspectos sobre a concepção de língua à qual a Análise Crítica do Discurso e, conseqüentemente, este trabalho se filiam; em seguida, como surge e o que pretende a Análise Crítica do Discurso. Esses aspectos são condições sine qua non para o tipo de análise a ser feita, e para pensar o sistema publicitário dentro dessa forma de encarar a língua.

Em seguida, serão elencadas algumas das categorias de análise, reconhecidas como válidas para o trabalho ao qual se propõe a Análise Crítica do Discurso (FAIRCLOUGH, 1990, 1999, 2001) e, que se fizeram necessárias ao longo desta pesquisa. Com base nestas categorias, procura-se, por intermédio da desconstrução dos vários elementos que compõem os textos publicitários, desvendar as estratégias argumentativas elaboradas pelos enunciadores e de que forma os sentidos vão sendo veiculados e se impondo aos leitores/consumidores, de acordo com as escolhas feitas, tais como: escolha de determinadas materializações sintáticas, de determinados operadores argumentativos em detrimento de outros, que dariam margem a outras interpretações que não as desejadas pelos produtores dos anúncios. Também serão usadas categorias semântico-pragmáticas que procuram explicar a opção por certas expressões fraseológicas, certos termos lexicais, de modo a evocar nos leitores os scripts necessários para contextualizar os anúncios, assim como para direcionar a conclusões desejadas.

Como esse trabalho analisa anúncios publicitários, publicados em revistas, e construídos com a função de atrair a atenção dos consumidores, também por intermédio de seu aspecto visual, não se pode deixar de discutir categorias que tentem esmiuçar essa linguagem visual. Para tanto, estas últimas categorias serão tratadas no subtítulo 'Categorias da Linguagem Visual'. 
O segundo capítulo será dedicado à discussão sobre a retórica e sobre como a publicidade usa, de forma atualizada, os conhecimentos dessa ciência. Com os filósofos gregos, surge a vontade de se compreender o mundo não mais como mágico, mas como a possibilidade de criação do 'verdadeiro' e do 'falso' por intermédio de uma boa formação do discurso. Nesse percurso surgem os sofistas, que primeiramente perceberam como se poderia criar a 'melhor verdade' através de uma boa argumentação e, para isso, desenvolveram grandes estudos que, até hoje, servem de impulso, para quem deseja entender como funciona a 'arte de convencer'.

Portanto, se quisermos analisar publicidade, que é a 'arte de convencer o consumidor', é necessário ocupar-se da retórica e da argumentação que é, justamente, o estudo do que se admite como sendo acordado entre os interlocutores, a quem se destina a proposição, sobre o ordenamento e encadeamento dos argumentos e de que tipo são, que tipo de adesão se busca, que aspectos são realçados, quais são apagados, em que ordem ocorrem, com qual objetivo estão nessa ordem, que tipo de ordenação do real se está pleiteando, quais efeitos de sentido previstos ou imprevistos provocam etc.

O terceiro capítulo aborda vários aspectos da publicidade: seu histórico; suas estruturas de argumentação, suas formas de estimular o desejo de consumo e as várias técnicas que adota para esse fim.

Não seria possível tratar desses temas sem levar em consideração a existência da comunicação de massas, que viabiliza as relações de consumo em grande escala. Por isso esses assuntos serão discutidos.

Nesse capítulo, também, serão discutidos alguns aspectos sobre 'mitos', suas funções, assim como seu uso pela publicidade. Serão investigados quais elementos mitológicos e qual inventário perceptual serão usados para compor as narrativas publicitárias aqui analisadas, além de quais materializações são escolhidas para esse fim e quais os possíveis significados dessas escolhas. Nesse espaço, serão apresentadas as categorias de análise destes elementos.

No quarto capítulo, serão discutidos os procedimentos metodológicos. Achamos melhor a colocação desse capítulo nesse local, porque é a partir dele 
que as análises começam a ser elaboradas. A melhor forma de análise encontrada para esse trabalho foi agrupar as peças de publicidade de acordo com as empresas anunciantes - anúncios da BASF na Alemanha e no Brasil e da Pfizer, com seus anúncios sobre o medicamento Viagra, também publicados na Alemanha e no Brasil - e compará-las dessa forma. O corpus foi coletado na revista semanal brasileira 'VEJA' e na alemã 'DER SPIEGEL', por serem ambas revistas semanais, com grande número de leitores, e voltadas para públicos de perfis semelhantes.

As análises seguirão no quinto capítulo, quando não houver necessidade de inseri-las na parte teórica a título de exemplificação. Finalmente, virão as conclusões e as referências bibliográficas.

As traduções de textos da bibliografia em línguas alemã e inglesa usados neste trabalho foram feitas pela própria autora. Os leitores deste trabalho têm acesso aos originais nas notas de rodapé. No caso da língua alemã, optou-se por grafar com "ss" toda palavra escrita com o "B". 


\section{ANÁLISE CRÍTICA DO DISCURSO}

\subsection{Concepção de língua}

Ao iniciar este trabalho, é necessário deixar registrada qual a concepção de língua que será usada. Isso é relevante, pois é a partir dessa concepção que a publicidade será enfocada, assim como será elaborada a comparação entre as publicidades nos dois países.

Desde já, reconhece-se a diferença entre língua e linguagem. Admite-se a língua como sendo as línguas naturais e linguagem como sendo um sistema mais abrangente, incluindo todos os códigos semióticos que fornecem algum tipo de informação. Encara-se a língua natural como sendo um dos 'sistemas' que compõem as linguagens utilizadas por seres humanos. Pode haver outros tipos de sistemas informativos como: de trânsito, de vestuário e muitos outros.

Sabe-se também que a linguagem, como sistema de comunicação, não é exclusiva do ser humano e que a língua natural, da forma como é articulada em vários níveis - fonológico, morfológico, sintático, semântico, pragmático - o é (LOPES, 1977). Porém, esse estudo reconhece que a língua é muito mais do que apenas o código lingüístico e se refere a limites que vão além do contexto em que ocorre a interação verbal. Reconhece, também, que muitas vezes são acionados outros tipos de sistemas comunicativos que interagem com o lingüístico, fazendo com que seus sentidos sejam potencializados, portanto os dois termos língua e linguagem às vezes poderão ser usados, ocasionalmente, como sinônimos.

Este trabalho parte do pressuposto de que a realidade é um construto social e biológico, sendo, portanto, dependente de inúmeras práticas sociais e biológicas. A língua, dentro desse contexto de construção da realidade, é uma dessas práticas sociais que concorrem para sua elaboração. Prática social é entendida como: "... modos de agir habituais, ligados a um tempo e espaço 
particular, na qual indivíduos aplicam recursos (materiais ou simbólicos) para agir conjuntamente no mundo" (FAIRCLOUGH, 2001, p. 21). ${ }^{1}$

A língua é um desses modos de ações habituais, um dos espaços de criação de sentidos que vão sendo produzidos tanto pelo falante ou escritor como pelo ouvinte ou leitor, imersos nessa realidade, que é anterior aos seus usuários e resultado de opções comunitárias, voluntárias ou não, conscientes ou não, que vão negociando, através da história, formas de significações. Isso determina que nossa forma de entender é condicionada por nossa posição no espaço e tempo, no aqui e agora em que nos encontramos. O que apreendemos com nossa visão é ficção dessa nossa posição nesse contexto espaço-temporal (BERGER, 1972, p.22).

A língua não é considerada como sendo um decalque da realidade, ela não espelha os acontecimentos, fenômenos, objetos, relações de maneira independente dos modos de uso impostos por regras de interação entre signos e signos, signos e usuários e os usuários entre si. A ilusão de uma língua como forma de retratar fielmente a realidade advém de uma concepção de ciência determinista que advoga a possibilidade de acesso direto, sem intermediação, a fatos, fenômenos etc. Ou como afirma Martin-Barbero (1998, p. 4): "O que continua sendo crucial para um discurso da comunicação ainda é freqüentemente enredado no idealismo de uma objetividade da informação que não é senão pretensão de um discurso sem sujeito." (itálico do autor).

A língua é ação cooperativa entre indivíduos que necessitam interagir para sobreviver, pelo menos da forma como a humanidade foi organizada. Como resultado dessa interação, ocorre a construção de realidades, que, por sua vez, vão remodelando as ações entre os indivíduos. De acordo com essa forma de encarar a língua, torna-se impossível aproximar-se dela apenas para a descrição de fatos lingüísticos, como se houvesse a possibilidade de um indivíduo falante/ouvinte/interagente não estar vinculado à história, às culturas, aos grupos nos quais vive. Não existe uma língua alienada das convenções sociais nas quais

\footnotetext{
1 “... habitualised habits, tied to particular times and places, in which people apply resources (material or symbolic) to act together in the Word".
} 
ela opera e pelas quais também é determinada. A língua é uma prática social cuja natureza é histórico-social e não apenas individual (BAKHTIN, 1995).

Essa discussão rejeita a concepção de língua apenas como um sistema imanente que se basta para poder ser explicado (SAUSSURE, 1977) e traz para o estudo da Lingüística outros fenômenos/elementos.

Um signo não existe apenas como parte de uma realidade; ele também reflete e refrata uma outra. Ele pode distorcer essa realidade, (...), ou apreendê-la de um ponto de vista específico etc. ... (BAKHTIN, 1995, p. 32).

Da mesma forma, entende-se que a língua se torna impossível fora da interação dos indivíduos e que todos os fenômenos lingüísticos são sociais, embora apenas uma parte dos fenômenos sociais seja lingüística. A enunciação humana é o produto da interação da língua com as condições de produção. Bakhtin, ao fazer essa escolha, traz para o estudo da Lingüística elementos que antes não faziam parte desse estudo, como o contexto social, cultural, econômico, histórico, local etc., além de evidenciar a existência de um indivíduo resultante de relações históricas de poder interagindo com outros indivíduos e grupos sociais.

Este sujeito situado histórica e socialmente trará para a concepção do que seja signo lingüístico uma dimensão de algo em estado de equilíbrio dinâmico, já que o signo não é visto como resultado de relações naturalizadas, isto é, algo como um terremoto, que provém das forças da natureza, mas como resultado de uma luta histórica para fazer valer os significados que interessam a determinados grupos em detrimento de outros que não tenham a mesma força para, também, tornar válidas suas vontades. O signo, encarado dessa forma, é a possibilidade do vir a ser, sempre imerso em uma relação de forças histórico-sociais:

No domínio dos signos, isto é, na esfera ideológica, existem diferenças profundas, pois este domínio é ao mesmo tempo, o da representação, do símbolo religioso, da fórmula científica e da forma jurídica. Cada campo de criatividade ideológica tem seu próprio modo de orientação para a realidade e refrata a realidade a sua própria maneira. Cada campo dispõe de sua própria função no conjunto da vida social (BAKHTIN, 1995, p. 33). 
O indivíduo terá que expressar essa vida histórico-social em algum tipo de signo, criado dentro de uma rede de possíveis significações: roupas, música, pintura, gestos etc. Estes, assim como as palavras, se encontram em inter-relação com outros signos, todos eles procurando definir um certo espaço de validade.

Portanto, a aparência neutra da ciência, o caráter dogmático da religião, a aparente onisciência do juiz e do médico, que detêm em suas mãos partes de nossas vidas, asseguram a manutenção da validade de determinadas significações, em detrimento de outras, dentro das instituições que representam. $O$ cotidiano, que aceitamos irrefletidamente porque 'todos' entendemos como sendo óbvio (natural), funciona como um véu que nos impede de refletir sobre conceitos, hábitos, afirmações etc., já estabelecidos como inquestionáveis. Portanto, a opção por determinada maneira de falar sobre as coisas, fatos, acontecimentos em um contexto específico, vinculada a um dado tempo e espaço, identifica-se com um modo específico de pensar e recriar discursivamente a sociedade (FOUCAULT, 2000).

Para este trabalho, a forma como se expressa a publicidade, por exemplo, é também um modo específico de perceber, pensar e recriar a sociedade, juntamente com outras formas de atuações como o sistema jurídico, religioso, etc. A materialização dessa forma específica de pensar a sociedade traz, ao longo do tempo, mudanças nos conhecimentos, crenças, valores, atitudes etc. Pensa-se, até, que seja capaz de, direta ou indiretamente, contribuir para modelar identidades individuais ou de grupos, seja como consumidores dos produtos anunciados ou como 'consumidores' dos próprios anúncios (FAIRCLOUGH, 2003), e, portanto, deve ser problematizada, ainda mais porque tantos afirmam que ela é essencial ao atual funcionamento e ordenamento da economia.

Uma das formas de compreensão de um signo ocorre pela sua aproximação com um signo já conhecido. Aprende-se através de signos, sem que sejam necessariamente palavras. Todos esses signos são criações comunitárias e só surgem no processo de interação social. A consciência só se reconhece como tal ao fazer uso desses signos, que são, desde a sua criação, impregnados de 
conteúdo ideológico (BAKHTIN, 1995). A inserção do ser biológico no contexto cultural é parte fundamental no processo de semiose.

Nesse processo de 'educação', passa-se a definir primeiro para depois passar a ver (LIPPMANN, 1972). Poderíamos afirmar que o mundo nos chega definido, porém não definitivo, já que nesse processo de aprendizagem e (re)construção da realidade, sempre há a possibilidade de mudanças, tanto esperadas, almejadas como inesperadas. Se o mundo nos chegasse definitivo, estaríamos até hoje na idade da pedra, o que não aconteceu.

Fairclough (2002, p. 20)² apóia-se em Bakhtin (1995) a fim de definir o que entende por linguagem, e afirma que este processo está ancorado "... por um lado em mecanismos biológicos humanos, por outro em mecanismos sociais..." A língua está, portanto, 'ancorada tanto em bases sociais como biológicas'. Surge de uma 'interseção entre o biológico e o social.' Sendo a linguagem uma 'emergência' dessa conjunção, não se poderia explicá-la isolando-a de um desses fatores.

Encarar a língua como algo inacabado, emergente de mecanismos biológicos e sociais implica não poder eliminar, definitivamente, nenhum desses mecanismos ao tentar pesquisá-la. O conceito de "emergência" em Fairclough (2002, p. 20) "... impõe que um mecanismo tem propriedades distintas que não são reduzíveis a outros mecanismos". ${ }^{3}$ Esse conceito chama a atenção para a impossibilidade de isolar ações ou influências de um mecanismo, quando este sofre, simultaneamente, ações de diferentes mecanismos. Fica-se incapacitado, enquanto pesquisador, de poder determinar, exatamente, até onde as influências dessas interações são percebidas ou controláveis.

No caso da publicidade, não é difícil perceber que a interpretação da linguagem visual, juntamente com a interpretação dos elementos lingüísticos, com o local da inserção dos anúncios, com o tipo de público a que se destinam e com outros fatores, potencializam a criação de sentidos.

\footnotetext{
2 "We might say it is rooted on the one hand in biological mechanism, and on the other hand in social mechanism, ..."

3 "... entails that a mechanism has distinctive properties which are not reducible to other mechanisms".
} 
Seguindo essa linha de pensamento, que avalia a língua como sendo uma prática social resultante de vários mecanismos interagentes, pode-se estudá-la como um 'sistema aberto', isto é, um sistema em que qualquer evento é influenciado por inúmeros mecanismos operativos, o que torna impossível separar, controlar ou determinar exatamente que tipo de influência cada um deles exerce (FAIRCLOUGH, 2002). Cada mecanismo operativo, atuando sempre conjuntamente com outros, gera fatos, acontecimentos que nem sempre são os esperados ou desejados, pois, sendo um sistema composto de vários mecanismos, não pode ter resultados completamente previsíveis. Portanto, um sistema aberto comporta sempre a possibilidade da imprevisibilidade e exige que isso seja levado em consideração quando analisado. Como conseqüência dessa dinâmica operacional, por não ser um sistema fechado, a língua traz consigo, além de concepções de mundo já estabelecidas entre os seus usuários, também as possibilidades de criações de novos caminhos.

Maturana (2001, p. 37) afirma que “... nós, seres humanos, somos humanos na linguagem, e ao sê-lo, o somos fazendo reflexões sobre o que nos acontece". A relação ser humano/linguagem funciona como uma espécie de feed-back, cada qual influenciando e sendo influenciado pelo outro num moto continuum bio-psicosocial de infinitas possibilidades.

Se concordarmos com Fairclough (2002) e encararmos língua como algo que emerge de uma conjunção entre o biológico e o social, teremos que aceitar que essa prática social chamada língua é uma das muitas práticas que regem a vida humana, da forma como ela está estabelecida. Portanto, a língua é um sistema aberto que acontece em um espaço de relações no qual interage como uma das atividades para a coordenação de ações de forma que elas possam ocorrer.

Um outro exemplo de sistema aberto é a vida. Esta é composta de vários mecanismos, que se pressupõem para poder existir: físico, químico, biológico, ecológico etc. A vida humana ganha ainda com algumas complexidades: capacidade humana de semiologizar, cognição, mecanismos sociais, culturais, econômicos complexos etc. A relação entre esses mecanismos, como já foi dito, é 
que eles se pressupõem e se exigem. Não podem ser isolados completamente em função de pesquisas e estão sempre incorporando a incerteza como componente.

Esses mecanismos que compõem a vida social são moldados por práticas sociais já definidas como hábitos que dependem da história conjunta dos indivíduos. Não se concebe vida social sem práticas sociais. Elas se expressam em todos os domínios da vida. São as materializações desses mecanismos que compõem a vida em sociedade, e trazem inscritas em si não apenas as determinações de espaço/tempo/história/sociedade etc., mas influências de outras práticas. Tudo isso só é viável por intermédio de uma organização muito bem orquestrada, sem que exista uma prática que seja mais importante que outra. Todas se pressupõem e se exigem. Esse tipo de organização provoca um equilíbrio dinâmico, possibilitando constantes rearranjos que se façam necessários para que a estruturação continue funcionando.

Essas práticas sociais têm, necessariamente, que se articular, que se colocar conjuntamente, agindo umas sobre as outras - não como se fossem peças de uma engrenagem, em que cada dente tem um lugar 'certo' para entrar, mas como um sistema relativamente plástico. É isso que possibilita influências recíprocas. O fato de agirem conjuntamente possibilita e exige um caráter de necessária permanência e estabilidade no momento em que ocorrem, mas o fato de que interferem, agem umas sobre as outras, abre espaços para variáveis, possibilitando mudanças, muitas vezes imprevistas, pois não é possível controlar todos os mecanismos no momento da ocorrência.

Esse processo de 'articulação' exige ao mesmo tempo adequação, 'obediência' e ao mesmo tempo uma flexibilidade, 'criatividade' de atuação necessária para determinados ajustes que se fazem necessários quando algo não está de acordo com o esperado (FAIRCHLOUGH, 2001). Significa, também, uma etapa de agregação do que já deu certo.

A natureza não desperdiça o que se comprovou eficaz. Se tomarmos, por exemplo, o cérebro humano, veremos que existe um cérebro primordial que é igual ao dos peixes, envolto por um cérebro que é igual ao dos répteis que, por sua vez é envolto pelo cérebro típico dos mamíferos. Os seres humanos contam 
ainda com o que se chama cérebro novo que é o córtex cerebral, considerado um acréscimo ao dos outros mamíferos.

No processo de evolução ou transcendência essas partes são somadas e transformadas no todo que é muito mais que a soma dessas partes. Quanto a esse tipo de organização, Wilber (2001, p. 49) afirma: "Portanto, a evolução é um processo de transcender e evoluir". Nessa união cada parte transcende a si própria com a agregação do que é característico das outras partes. A etapa posterior é sempre a "essência do inferior e algo mais". (Ibidem, p. 5) e todas elas são igualmente importantes, não havendo juízo de valor entre as etapas.

Retomando Bakhtin (1995), é Interessante notar que este vê de forma semelhante a atuação de elementos contextuais históricos, sociais e outros na língua. Usa para isso o conceito de forças centrífugas e centrípetas, que agem conjuntamente na língua. Afirma que a língua traz consigo, além de concepções de mundo já estabelecidas entre os seus usuários, também a possibilidade de criações de novos caminhos.

Chama a atenção para a palavra do outro - este como todos os indivíduos que formam os grupos chamados 'comunidades lingüísticas'. Nestas, os membros dialogam entre si, em relações de força, nas quais cada palavra é parte de uma 'teia' e detém em si própria uma tensão que se expressa de todas as maneiras. Seja no plano do conteúdo ou no plano da forma, num todo indivisível, formando um diálogo contínuo, onde forças de união e desunião atuam constantemente.

O autor dá a essas forças o nome de 'união de forças centrípetas e centrífugas'. As primeiras tentam manter esses discursos, assegurando a concepção de um mundo, aparentemente, homogêneo. Tentam estabilizar o valor do signo tornando-o imóvel. Estas teriam, portanto, um caráter conservador, reacionário. Para isso existem gramáticas consideradas oficialmente corretas, escolas encarregadas de ensiná-las, uma língua considerada nacional, normas cultas, aceitas como as únicas capazes de representar uma cultura. Não esquecendo, tampouco, os sistemas de sanções desenvolvidos por instituições detentoras de poder, para aplicá-las em indivíduos que a esses valores não se submetem ou que a eles não têm acesso. Instituições e indivíduos a elas 
pertencentes são levados a controlar mutuamente, no âmbito desses domínios, o que chamam 'conhecimento válido' (BOURDIEU, 1996, 1997).

A essa força conservadora centrípeta, que Bakhtin (1995, p. 81) diz ser "regida por combinações lingüísticas sistemáticas entre elementos interdependentes e complementares", corresponderia uma força 'centrífuga', que faz com que uma mesma língua, apesar de tender para a coesão, tenha, ao mesmo tempo, uma certa plasticidade indomável, que não é claramente percebida e, segundo o autor, esta seria, justamente, a condição para sua realização. Dentro dessa aparente coesão, atuariam várias forças que concorreriam para mudar a correlação de poder, o que obriga essas forças centrípetas da vida social, lingüística e ideológica a barganhar a respeito das mudanças com o intuito de conseguir manter-se em lugar privilegiado de exercício de poder.

Essas posições antagônicas coexistem e se articulam dentro da mesma língua, nas mesmas comunidades lingüísticas. Isso significa que o signo é um espaço de exercício de poder, no qual co-ocorrem e competem interesses sociais diversos, que tentam definir e controlar suas potencialidades e é dessa dinâmica que se sustenta sua vitalidade e também imprevisibilidade.

Essa forma de organização/articulação entre a prática lingüística e outras práticas seria um conjunto de potencialidades em que o caráter de sociabilidade é fundamental, e cuja estratégia de sobrevivência se evidencia na linguagem. Se todos esses mecanismos evolutivos de sobrevivência funcionam de maneira articulada (FAIRCLOUGH, 1999, HARVEY, 2004), como separar um deles, no caso a linguagem, para analisá-la como se ela funcionasse autonomamente?

Essa pressuposição e exigência das práticas sociais entre si são modos de regulamentação. Ou seja, a materialização dessas práticas em forma de normas, hábitos, leis, redes de regulamentação etc. é o que garante a sua própria reprodução. As práticas sociais são, ao mesmo tempo, formas de selecionar e de controlar o que pode ocorrer, o que pode se materializar a partir de determinadas estruturas sociais em eventos. Elas são o mecanismo que serve de intermediação entre as estruturas sociais e suas ocorrências (FAIRCLOUGH, 2003). 
Considera-se que as emergências conjuntas de diversos elementos da vida numa determinada prática são 'momentos' dessa prática. Por isso a importância da definição de 'sistema aberto.' Todo 'momento' pressupõe e exige outros, traz em si outros momentos, não podendo, portanto, ser reduzido a si próprio. Há sempre uma remissão a um ato anterior, seja para negá-lo ou corroborá-lo. Uma das ocorrências da materialização desses 'momentos' se manifesta em forma de textos.

O conceito de texto como a materialização do 'momento' de uma prática é definido por Beaugrande (1997, p. 10): “... evento comunicativo para o qual ações lingüísticas, cognitivas e sociais convergem, e não apenas como uma seqüência de palavras que foram expressas ou escritas". ${ }^{4}$ O autor chama a atenção para essa convergência de sistema interativo múltiplo, onde seus elementos são multifuncionais. Ele mantém, portanto, essa idéia de um "sistema aberto", assim como o da 'transcendência' das partes ao se unirem.

Heinemann; Vieweger também definem texto como um sistema aberto e multifuncional:

... resultados de atividades lingüísticas de indivíduos que atuam socialmente, nas quais foram atualizados saberes de diferentes tipos, dependentes de avaliação cognitiva dos participantes da ação, como também do contexto de ação, que se manifestam em texto, de maneira específica/apropriada ... (HEINEMANN; VIEWEGER 1991$, p. 126) $)^{5}$

O texto, visto desta forma, exige mais do que a análise da relação dos signos lingüísticos no interior da frase, ou do que a análise da relação entre as frases dentro de um conjunto delimitado de frases. Desloca-se a ênfase da análise 'do que o texto diz' para uma discussão sobre possíveis sentidos recriados por diferentes auditórios em diferentes contextos. Qualquer texto é parte de um complexo de ações interacionais que visam a alcançar um objetivo, é resultado de

\footnotetext{
4 "...text as a communicative event wherein linguistic, cognitive, and social actions converge, (itálico do autor) and not just as the sequence of words that were uttered or written".

5 "Unter Texten werden Ergebnisse sprachlicher Tätigkeit sozial handelnder Menschen verstanden, durch die in Abhängigkeit von der kognitiven Bewertung der Handlungsbeteiligten wie auch des Handlunfskontextes vom Textproduzenten Wissen unterschiedlicher Art aktualisiert wurde ..."
} 
um processo interacional que requer o uso de estratégias cognitivas, para adquirir sentidos.

Essas estratégias devem ser aplicadas tanto por seus produtores como por seus receptores para que possam, conjuntamente, negociar sentidos possíveis do é dito/escrito/ouvido/lido e também visto, no caso das publicidades. São estratégias no nível da língua e também no âmbito de interações interpessoais. Não se entende mais esse processo de comunicação como sendo apenas as intenções do emissor de se apossar de um código a fim de passar uma informação a um receptor, uma "concepção condutista" segundo Martin-Barbero (2002, 41).

O número de possibilidades de realizações textuais em nossas complexas sociedades é quase infinito, já que as necessidades de interações são as mais diversas. Portanto, encara-se a vida em sociedade como uma intersecção de textos produzidos indefinidamente, que adquirem como que uma vida própria, pois o que produzimos transmite sentidos que quase nunca podem ser controlados de acordo com os desejos ou intenção do falante/ouvinte, escritor/leitor. Ou nas palavras de Harvey (1989, p. 53): "É vão tentar dominar um texto, porque o perpétuo entretecer de textos e sentidos está fora do nosso controle; a linguagem opera através de nós". Portanto, não há sentido em procurar 'a informação' contida dentro de um texto e sim os efeitos de sentidos construídos pelos interlocutores que produzem esse texto dentro do tempo, espaço, relações sociais, culturais, econômicas etc.

Além dos conhecimentos, que os falantes/ouvintes devem ter, relativos ao sistema e contexto lingüístico, necessários para a elaboração do texto, devem ser acionados conhecimentos sobre a compreensão e movimentação do ser humano no espaço, tempo e sociedade em que vive. Esses conhecimentos são determinados como 'conhecimento de mundo ou enciclopédico' segundo van Dijk (1996), Heinemann; Viehweger (1991), Koch (1995, 1996).

Segundo esses autores, os indivíduos armazenam cognitivamente 0 mundo, o conhecimento de fatos, objetos, fenômenos, acontecimentos etc. em blocos de associações que supõem algum tipo de relação entre eles. Esses blocos 
de associações são guardados em forma de modelos cognitivos dinâmicos que recebem o nome de 'frames' e 'scripts'.

Os primeiros seriam a "ordenação dos conhecimentos em um padrão modelar relativamente fixo" (FIX, 2003, p. 15). Um exemplo disso é nosso conhecimento de elementos que compõem 'escola': carteira, quadro, sala de aula, professor, aluno etc. Scripts seriam os mesmos objetos de conhecimento armazenados associativamente nos frames, porém, agora, relativos à ordem de ocorrência dos acontecimentos, podendo se estabelecer um padrão nessa repetitividade, que faz com que os indivíduos saibam o que fazer, de maneira ordenada seqüencialmente, em determinadas circunstâncias, acontecimentos (ibidem, 2003).

O mesmo exemplo fornecido acima, com os elementos que compõem a escola, pode ser usado, agora com a seqüência de ações necessárias para realização de um ato: o aluno levanta de manhã, toma banho, veste-se, vai para a escola, de ônibus ou carro, entra na sala de aula, cumprimenta amigos, professor, senta-se na cadeira, em frente ao quadro ou em círculo etc. Talvez o fato de usarem elementos comuns no momento do armazenamento torne difícil separar esses dois modelos de procedimentos de maneira estanque.

Esses parâmetros, modelos de saber, organizados cognitivamente em forma de redes de associações de palavras, temas ou seqüenciação de atividades, armazenados de maneira relativamente fixa, mas potencialmente mutável, determinam a forma de entender, avaliar e modificar o mundo onde vivemos e de nele nos locomovermos e agirmos.

Os modelos cognitivos seguem uma coerência coletiva, e, portanto, cultural, mas também dizem respeito a experiências individuais. Pelo fato de as experiências serem armazenadas em forma de frames e scripts que estão de acordo com a cultura à qual o indivíduo pertence, o uso de determinadas palavras, quando atualizadas nos textos, carregam consigo mais informações do que aparentam ter.

O uso dessa estratégia são formas “... econômicas de direcionamento emocional e argumentativo do leitor, com as quais podem ser evocados 
conceitualizações e estereótipos refletidos socialmente..." (HOLLY, 2006, p. 12) ${ }^{6} \mathrm{e}$ dessa forma pode-se perseguir quais sentidos são pretendidos pelo produtor do texto. São mecanismos cognitivos culturais e individuais que determinam o que é adequado, esperado ou vedado fazer em determinadas circunstâncias.

Esses modelos e estratégias cognitivas dão instruções para grupos e indivíduos agirem no mundo, auxiliam na compreensão de fenômenos e processos, preenchem lacunas que porventura existam nos estímulos auditivos, visuais, olfativos e textuais etc., que chegam até nós. Permitem que possamos trabalhar, não só com avaliações passadas, mas também com antecipações, montando hipóteses e refazendo-as caso se mostrem erradas.

Esse conhecimento de mundo em modelos cognitivos, armazenado em forma de associações dinâmicas, é ativado, no caso dos anúncios, em publicações impressas, por elementos visuais e textuais que funcionam como pistas. Dessa forma, possibilitam a contextualização da narrativa e preenchem lacunas necessárias para fornecer coerência aos textos, já que se pode afirmar que nenhum texto contém toda a informação necessária para sua interpretação.

Trabalha-se, portanto, com antecipações, partindo do princípio de que os indivíduos têm conhecimentos comuns, subentendidos. Os indivíduos tornam-se, então, responsáveis por processos inferenciais que preenchem essas lacunas. Responsáveis no sentido de ter que participar ativamente no processo de compreensão. Essas inferências são estimuladas pelas lacunas textuais, mas mantidas dentro de um certo limite estipulado pelo próprio texto e contexto.

A utilização desses modelos cognitivos possibilita o desenvolvimento de uma interação como uma prática na qual se constroem sentidos para além do que é fornecido como informação, levando em consideração a experiência de vida do leitor/ouvinte, seu conhecimento de mundo, inserção cultural, conhecimento lingüístico, criatividade.

É por esse motivo que o uso de determinadas expressões lingüísticas detona automaticamente certas vivências e sentimentos na mente dos indivíduos,

${ }^{6}$, ,... Ökonomische Mittel der emotionalen und argumentativen Lesersteuerung, mit denen sozial eingespielte Stereotype und Konzeptualisierungen aufgerufen (...) werden können“. 
já que algumas formas fixas da língua se aderem aos sistemas de relacionamentos quando essas situações vão sendo repetidamente vivenciadas com as mesmas formas lingüísticas. Dessa forma surge toda uma fraseologia usada de acordo com relações afetivas, profissionais etc. Isso explica, por exemplo, o uso hegemônico que a publicidade faz do slogan, sempre tentando acordar no leitor/ouvinte a lembrança da marca. Segue nessa linha o uso de adjetivos ou expressões que procuram desencadear vivências e sentimentos positivos do leitor/ouvinte com os objetos ou serviços anunciados: "perfeito, (...), original, (...), delicioso (CARVALHO, 2003, p. 39).

Lembramos que os textos de nosso material de pesquisa são compostos por mais de um código semiótico, tratando-se, portanto, de textos multimodais. Do mesmo modo que a língua não é transparente, tampouco o são as imagens que vemos impressas em livros, jornais, revistas etc. A comunicação visual também é baseada em códigos pré-estabelecidos cultural e socialmente. Um código, ocidental em nosso caso, com o qual estamos acostumados, pode, muitas vezes, nos levar a entender que as imagens são imparciais, porque 'apenas mostram o que está na realidade'. Qualquer sociedade tende a desenvolver um sistema de valorização na forma de composição de imagens, que é reconhecido quase que inconscientemente por boa parte de seus integrantes e que funciona como uma estratégia de argumentação (KRESS; van LEEUWEN, 2001).

A teoria dos modelos cognitivos pode explicar de que forma o leitor, baseado nesses parâmetros de modelos de saber, dentro de segundos, identifica e atribui um certo valor à situação em que se encontram os personagens de uma narrativa publicitária e é capaz de montar uma série de associações coerentes que forneçam sentidos ao que ouve, lê ou vê.

De todos os sentidos que o ser humano usa para se comunicar com o meio, a visão é o que consome menos energia (DONDIS, 2003) e permite uma gama maior de interpretações do que a imposta pela língua. A publicidade conta com isso, já que o espaço temporal e físico é exíguo.

Em nosso corpus, o leitor do anúncio da BASF, ao 'ler' a imagem de um homem dependurado por uma corda, junto a uma montanha, ou a de um pai com 
um filho, identifica de imediato os scripts aos quais estão vinculadas essas estórias, podendo, imediatamente, contextualizar os anúncios dentro de suas estruturas de cognição, completar o que pode estar faltando com os seus scripts culturais coletivos e individuais e, se tudo correr de acordo com o desejado pelos anunciantes, com o inventário perceptual e sentidos aos quais a BASF deseja ser ligada.

Essa discussão sobre como se percebe a língua, dentro de todo um sistema de práticas sociais, se faz necessária, pois a forma de encarar a publicidade se divide, grosso modo, em duas maneiras: uma que discute a publicidade como sendo algo semelhante a um serviço público, destinado a informar aos consumidores a respeito do que está sendo produzido e posto em disponibilidade para a aquisição. A outra visão encara a publicidade como uma atividade capaz de reorganizar o cotidiano, interferir em crenças, estimular desejos, criar valores etc.

A primeira forma de pensar é uma extensão da visão ideológica que prega uma possível neutralidade, tanto da língua como das imagens visuais. A segunda não é tão 'inocente', a ponto de achar que são veiculadas apenas informações a serviço do público, num possível 'modelo condutista' como diz Martin-Barbero. Neste estudo, a autora procura discutir a publicidade dentro dessa segunda opção.

Com o que foi exposto até aqui, espera-se ter deixado claro que, para este trabalho, a língua é encarada como uma prática social, que ocorre por intermédio de um 'sistema aberto', que pressupõe mecanismos físicos, biológicos, lingüísticos, cognitivos, articulados com outras 'práticas' sociais, culturais, econômicas etc. e que se expressa por intermédio de textos que podem ser multimodais ao trazerem como elementos do processo argumentativo diferentes códigos semióticos.

A língua é, entre as muitas práticas sociais existentes, a que mais contribui para a construção da realidade, isto é, uma construção discursiva que fornece sentidos a nossa existência em sociedade. Encontra-se articulada com outras práticas, o que necessita de uma relação de equilíbrio, que não pode ser estático 
senão corre o perigo de se tornar incapaz de responder às mudanças, cada dia mais freqüentes, em nossa sociedade.

Ela permite e exige, portanto, uma certa instabilidade que dá margens a mudanças nem sempre esperadas ou desejadas por seus usuários, numa espécie de equilíbrio dinâmico. Não é vista como um sistema que se basta por si só, único e homogêneo, mas é composta por inúmeras linguagens que, com infinitas vozes, ressoam em todos os aspectos da vida em sociedade. Todas, repetindo-se umas às outras, alimentando-se e se retroalimentando dentro dessa 'arena' onde se digladiam todos os ecos, sem que os indivíduos que delas fazem uso dêem-se conta. A língua se materializa em 'momentos' que trazem em si outros momentos dos quais não podem ser separados.

Essa concepção de língua, como sendo uma prática social integrante, juntamente com outras, de uma determinada forma de construção da realidade, é necessária para este trabalho já que ele se apóia nas categorias de análise pleiteadas pela Análise Crítica do Discurso e em autores que trabalham com outras categorias que procuram explicar de que forma o ser humano atua com a linguagem.

\subsection{Análise Crítica do Discurso}
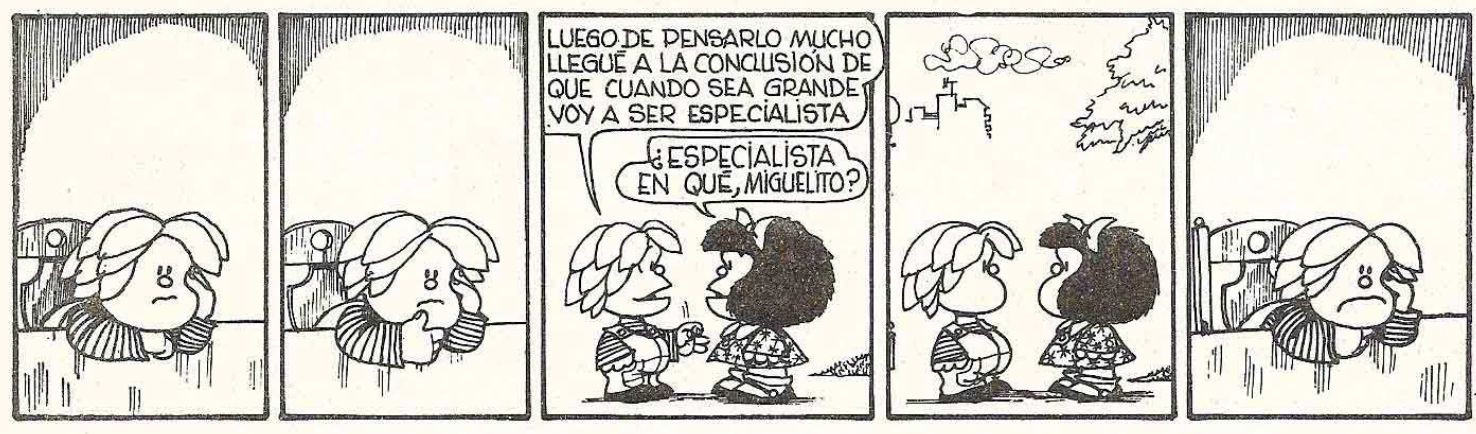

(LAVADO/QUINO, 1979)

A Análise Crítica do Discurso tem início, segundo van Dijk (1993, p. 251), na Austrália e na Grã-Bretanha, com estudiosos como Halliday, Fowler, Hodges, 
Kress, Fairclough. Para os autores Jaworsky e Coupland (2000), o termo 'crítica' foi inserido para diferenciar esse tipo de análise, que procura identificar e explicar relações de exercício de poder e dominância dentro do discurso e sua importância para a construção da sociedade, do trabalho que vinha sendo desenvolvido por David Coulthard e outros na Grã-Bretanha. Estes últimos, a princípio, limitavam-se a estudar interações orais dentro de sala de aula e davam o nome de Análise do Discurso a esse trabalho.

A Análise Crítica do Discurso pretende ser um estudo multidisciplinar e coloca-se no campo de estudo da ciência social. Encara a vida em sociedade como sendo, por um lado, limitada por estruturas e práticas sociais, e, por outro, como um processo ativo de produção na qual está embutida a capacidade de modificação dessas mesmas estruturas sociais.

O objetivo principal da Análise Crítica do Discurso (doravante, identificada pelas iniciais $A C D$ ) vai além da descrição de elementos lingüísticos. Ela procura esclarecer a relação entre discursos, relações de poder e dominação e como isso constrói representações sociais, com as quais os indivíduos interpretam seu cotidiano, e qual o papel do discurso na produção e reprodução dessas relações.

Procura questionar a respeito da crença na objetividade da linguagem, crença esta que 'naturaliza' fatos, acontecimentos, objetos etc., que são historicamente determinados, mas que em conseqüência desta 'naturalização' se apresentam como inquestionáveis para a maioria dos indivíduos.

A ACD encara a sociedade como uma série de grupos e instituições estruturados, principalmente, por intermédio do discurso, entre outras práticas. Esta forma de encarar a sociedade não é característica exclusiva da $A C D$, mas a aproxima de Foucault, Bourdieu, outros, nos quais ela se apóia para fundamentação teórica. Seria, portanto, mais uma tentativa, entre outras, de deixar claras as possíveis relações não só de produção, como também da interpretação do processo discursivo.

Não se pretende apenas levantar questionamentos sobre as ações das estruturas sociais sobre os indivíduos, mas também demonstrar a possibilidade de que isso não deve ser encarado com um fatalismo que leve à passividade e à 
aceitação das relações de poder estabelecidas. Sua intenção é colocar o indivíduo como um agente que percebe essas relações, por intermédio da problematização dessas relações de poder, que se instauram, também, por meio da prática discursiva. Para isso se apóia em várias categorias de análise que serão discutidas posteriormente.

A ACD estuda como, através de estratégias, a estruturação de textos (texto aqui no sentido de processo de produção e interpretação falada ou escrita), encarados como eventos comunicativos, para os quais convergem ações além do nível lingüístico, desempenha seu papel dentro dessa complexa dinâmica que é a interação humana, e, como os textos contribuem, tanto para a construção da sociedade como também com seus "modos de reprodução" (van DIJK, 1993, p. 250).

Estratégia, segundo Bimmel (1993, p. 5) “... são planos de ações (mentais) a fim de alcançar um objetivo". Ou segundo Koch (1983, p. 400): “... é uma instrução global para cada escolha necessária a ser feita ao longo do curso da ação". Se considerarmos estratégias como planos, podemos então considerar que existe uma certa escala de 'consciência' nesse processo de escolhas possíveis.

Em um texto escrito, com certeza a preferência pelo uso de certas estratégias é mais consciente do que na fala espontânea. Se considerarmos estratégias como planos mais ou menos conscientes, podemos pensar que existem preferências em usar algumas estratégias, talvez mais adequadas aos objetivos a serem alcançados, e que cada escolha implicaria determinadas intenções de ação ou reação.

Reconhece-se a complexidade do processo de compreensão e produção textual, principalmente, neste trabalho que lida com textos multimodais. Procurase analisar a estratégica opção pelo uso de determinado termo lexical, determinado elemento coesivo entre enunciados, certas materializações sintáticas, a opção por uma expressão fraseológica que evoca determinado script e não outro etc., assim como determinado ângulo, tom, lugar de posicionamento dos objetos etc. a ser usado em uma foto para o anúncio. $\mathrm{E}$ de que forma a ocorrência dessas

\footnotetext{
7 "Strategien sind (mentale) Handlungspläne, um ein Ziel zu erreichen."
} 
escolhas, juntamente com contextos extra-lingüísticos expressam diferentes formas de agir no mundo, de relacionar-se com outros indivíduos, de construir a realidade. Como já foi dito, nenhuma enunciação ocorre num vácuo têmporoespacial. Vários fatores vão entrar em jogo nessa aparente 'naturalizacão' da linguagem.

Esse campo de pesquisa procura discutir por que o uso "ingênuo" de formas gramaticais, lexicais, gêneros textuais etc., que permanecem aparentemente estáticos ao longo do tempo, como formas fossilizadas de relações entre pessoas, indica formas de expressão de relações de poder e dominância. Dominância é definida por van Dijk (1993, p. 249) ${ }^{8}$ como “... exercício do poder social pelas elites, instituições ou grupos sociais que resulta em desigualdade social, incluindo desigualdade política, cultural, de classe, étnica, racial e de gênero".

Deve-se deixar claro que 'elites', para esse mesmo autor (idem, 1992), não são algo abstrato, mas grupos colocados em instâncias de atuação de poder, com força de decisão e implantação das decisões que são, por eles, tomadas, como políticos, intelectuais em cargos de decisão, grandes empresários etc. A própria pretensão de naturalização, de neutralidade nas relações de interação construídas historicamente e expressas na forma da construção da argumentação pode ser vista como uma ideologia que fornece ilusão de objetividade, tão cara à sociedade com o seu discurso que pleiteia uma objetividade da informação.

Koch (1996, p. 19), também chama a atenção para a parcialidade do ato de argumentar que corrobora o que foi afirmado acima: "A neutralidade é apenas um mito: o discurso que se pretende 'neutro', 'ingênuo', contém também uma ideologia, a da sua própria objetividade".

A Ideologia, na ACD, é levada em consideração como uma modalidade de poder. São as realizações de representações de alguns aspectos da realidade que podem ser identificados como participando ativamente e como apoio para a manutenção de determinadas relações de poder e dominância entre grupos ou que, em alguns momentos, podem também contribuir para mudanças nessas

$8 " .$. exercise of social power by elites, institutions or groups, that results in social inequality, including political, cultural, class, ethnic, racial and gender inequality." 
relações. Essas representações podem ser identificadas nas materializações das práticas sociais como as textuais e, portanto, podem ser problematizadas.

A existência das práticas sociais, como sendo dependentes de momentos marcados historicamente, define como sendo possível a expressão de alguns aspectos da realidade enquanto exclui outros que, em determinados momentos históricos não são aceitos. Essas práticas, como formas de organização, fazem a intermediação entre a estrutura social língua e os eventos sociais textos. As práticas sociais, encaradas dessa forma, são encadeamentos acionais que controlam o que pode ser textualizado, dito. Portanto, encarar o texto como um evento social no qual interferem vários fatores é preocupar-se com ele como expressão da possibilidade de ocorrência de determinado processo de interação em detrimento de outros que são silenciados, como uma constante negociação de sentido (FAIRCLOUGH, 2003).

O estudo do funcionamento da linguagem passa a ser uma das tarefas que possibilita um exercício democrático, pois a linguagem é imprescindível em quase todas as práticas sociais. Um estudo crítico da mesma, e de suas variadas formas de funcionamento e atuação, dificultaria a manipulação de leitores ou ouvintes por produtores que pretendem que esta seja vista como naturalizada. É um meio de despertar os indivíduos dessa 'ingenuidade' representada pelo senso comum.

Senso comum são suposições - algo tomado como fato ou verdade, sem necessidade de comprovação - implícitas em conversações da vida cotidiana, de acordo com as quais as pessoas interagem lingüisticamente e das quais geralmente não se dão conta (FAIRCLOUGH, 1990). Os fatos, acontecimentos, costumes etc. passam a fazer parte do senso comum porque, com o tempo, têm suas origens apagadas e passam a ser encarados como óbvios, algo tomado como verdade, sem necessidade de comprovação. Aí o trabalho com as noções de frames e scripts tornam-se importantes, pois é essa uma das formas de organização da aquisição de conhecimentos que permite a incorporação do senso comum.

Esse autor reconhece a linguagem como sendo o espaço de luta por aquisição e manutenção de poder. (ibidem, p. 40). Nesse ponto, língua e discurso 
se igualam, pois o último é a realização da primeira e ambos são vistos como uma forma de prática social. Para ele, existe um 'poder no discurso', isto é, participantes poderosos controlando e restringindo as intervenções dos não poderosos (ibidem, p.46). Seriam relações assimétricas que ocorrem em relações face a face. Exemplos disso é a conversa entre um diretor e um funcionário ou entre um professor e um aluno. Os primeiros terão mais razão e serão mais ouvidos. O controle sobre as intervenções ocorre tanto no que diz respeito ao que se fala e se faz, quanto no papel que cada um exerce nas relações estabelecidas.

Existe, ainda, um 'poder atrás do discurso' (ibidem, p. 55). Este está relacionado com as convenções sociais, institucionais, estaria sujeito às regras de formação dos enunciados que co-existem sob o discurso e validam ou não o que é falado. São menos claramente identificáveis do que as que acontecem nas relações face a face. Um exemplo do segundo caso é a forma como um padre organiza o seu sermão a fim de divulgar idéias religiosas garantidas pela instituição igreja, ou como um juiz organiza seu discurso, de maneira a justificar sua sentença.

Fairclough identifica ainda o 'poder escondido no discurso' que ocorre entre participantes separados espacial e temporalmente como, por exemplo, em textos escritos e nesse tipo inclui-se o discurso da mídia: “... onde há uma clara divisão entre os produtores e os intérpretes..." (ibidem, p.49) ${ }^{9}$. O nosso objeto de análise os anúncios publicitários veiculados em revistas - coloca o leitor nesta última relação, já que este se encontra separado do produtor, temporal e espacialmente.

Surge também, nessa relação, como intérprete desses textos publicitários, o que Fairclough, assim como Perelman; Olbrecths-Tyteca (2002), chamam de 'sujeito ideal', já que os produtores dos textos devem ter em mente um leitor prototípico que desejam atingir com seu discurso. É essa idéia de que o produtor escreve para um protótipo de leitor, um leitor ideal, que nos permite afirmar que os anúncios publicitários buscam o que há de conhecimento partilhado, o que é acordado entre os integrantes dessas comunidades consumidoras dos anúncios,

9 "...in the media discourse, as well as generally in writing, there is a sharp divide between producers and interpreters..." 
para poder atingir o maior número de possíveis compradores, procurando evitar dissonâncias cognitivas (RANDAZZO, 1997), que poderiam acarretar na rejeição do produto oferecido.

O exercício do poder não é feito somente de forma negativa, como forma de uma minoria controlar e explorar boa parte da população que ou não percebe 0 que acontece ou não tem meios para se contrapor a isso. Pode-se afirmar que há um poder exercido de forma positiva, um poder capaz de ocasionar mudanças, de reconfigurar sentidos 'fossilizados'. É o que van Dijk (1997) chama de 'contrapoder', pois dificilmente o poder se instaura de maneira absoluta. Sempre existem grupos que conseguem exercitar uma reação crítica ao poder instituído. Este seria um poder transformador, necessário e positivo.

Essas relações de poder e dominância são produzidas e reproduzidas conjuntamente entre os participantes de interações. Considera-se interação não apenas como sendo a relação entre dois ou mais atores que se encontrem face a face, mas como toda ação conjunta, conflituosa ou cooperativa (VAN DIJK, 1993). Para explicar a construção dessa relação de dominância, a ACD usa o conceito de hegemonia ou o modo como um poder governante negocia a conquista da permissão para governar.

Para van Dijk (1993) e Fairclough; Chouliaraki (1999), um grupo ou classe dominante pode assegurar o consentimento para que exerça o poder, alterando alguns aspectos das relações sociais, econômicas, políticas etc., de forma que outras classes sociais ou grupos sintam-se, de alguma forma, contemplados em seus desejos, fazendo com que todos, pelo menos momentaneamente, sintam-se satisfeitos com o status quo. São 'acordos' feitos durante determinados períodos, tendo que ser refeitos de tempos em tempos. Seria um 'equilíbrio dinâmico', pois nada está definitivamente assegurado por grupo algum. Esse 'acordo' tem que ser continuamente renovado, defendido, modificado, segundo os acontecimentos e novas relações que vão surgindo e interferindo nessa construção social. Seria uma permanência relativa de articulações de elementos sociais. Sobre isso Eagleton afirma: 
Muito toscamente, então, podemos definir a hegemonia como um espectro inteiro de estratégias práticas pelas quais um poder dominante obtém o consentimento ao seu domínio daqueles que subjuga. Conquistar hegemonia no parecer de Gramsci, é estabelecer liderança moral, política e intelectual na vida social, difundindo sua própria "visão de mundo" pelo tecido da sociedade como um todo, igualando, assim, o próprio interesse com o da sociedade em geral (EAGLETON 1997, p. 107).

Por isso, as definições de Fairclough (2002) a respeito de práticas sociais, como um "conjunto de ações habituais dependentes do tempo e espaço, nas quais indivíduos aplicam recursos (materiais ou simbólicos) para agir conjuntamente no mundo" e sistemas abertos se encaixam tão bem ao conceito de hegemonia, dado pelos dois autores citados acima. Ao mesmo tempo em que é impossível separálas, também é impossível controlar rigidamente todas as mudanças que ocorrem em função do processo de articulação entre essas variáveis. Essas práticas se juntam de acordo com as relações entre elas. Isso exige ao mesmo tempo uma certa permanência e uma certa flexibilidade para que o sistema não entre em colapso. Daí ser interessante o uso do conceito de hegemonia como uma negociação entre classes ou grupos.

Visto dessa forma, o exercício dessas estratégias para manutenção do poder pelo grupo mais forte não é prerrogativa do capitalismo, mas parece que, nele, a razão da subjugação que normalmente oscila entre a coesão pelo consentimento ou pela força, parece pender para a primeira forma de coesão.

Encaramos que, atualmente, uma das melhores formas de cooptação dos mais diversos grupos sociais para a hegemonia das idéias do sistema econômico de mercado globalizado é a publicidade. Esta é um 'bem cultural' com função pedagógica e, portanto, com poder de organização social, como será discutido no capítulo 3. Esses bens culturais, produzidos com palavras e imagens, circulam e são consumidos. Tudo isso dentro de uma prática material de produção e de troca de bens.

A linguagem também se transforma num bem a ser adquirido. Todos esses discursos lutam dentro de um 'mercado lingüístico' e cada um tem um determinado 'valor' dentro do processo de 'troca'. As interações, que são 
chamadas por Bourdieu (1996) de 'trocas lingüísticas', não seriam simplesmente interações, mas interações simbólicas, isto é, relações de comunicação que implicam o conhecimento e o reconhecimento dos signos no momento de seu uso. Não é suficiente conhecê-los. Estes, quando expressos, interagem em "relações de poder simbólico onde se atualizam as relações de força entre os enunciadores ou seus respectivos grupos" (ibidem, p. 24).

Essa linguagem passa a ser 'comodificada', isto é, linguagem tornada bem de consumo. Saber e poder usar determinados modos de se expressar, que dentro desse mercado lingüístico proposto por Bourdieu, significa ter um maior poder de barganha e permite aos usuários ou seus respectivos grupos um maior poder de 'falar' e de ser 'ouvido'.

Ocorre também, muitas vezes, nesse processo de comodificação, a 'colonização' de um domínio discursivo por outro, com mais prestígio junto à comunidade lingüística. Isso não é muito difícil de perceber no anúncio da BASF brasileira quando esta usa termos como: "ecoeficiência aplicada". A partir dessa 'colonização' de um domínio discursivo por outro, tem-se processos de 'reengenharia lingüística' tanto nas instituições públicas quanto no próprio âmbito da vida cotidiana dos indivíduos, onde os fatos e as relações entre as pessoas, são renomeados, para que adquiram novos sentidos. Surgem novos vocábulos que devem ser aprendidos pelos indivíduos, envolvidos nesse processo.

Conseqüentemente, os indivíduos devem se adaptar a modernas formas de significações, para se mostrarem atualizados. Ao mesmo tempo em que essas resignificações procuram dar a entender que novas relações surgiram, apenas mascaram velhas relações conflitantes. Como o uso dos termos: 'jovens de baixa renda' no mesmo anúncio.

Habermas (1989) procura problematizar formas de interações, da comunicação humana, principalmente nas sociedades, nas quais o poder de exercer influências ocorre por intermédio do uso da linguagem, e não da força, como forma de estabelecer novos espaços de atuação. $O$ autor discute as interações entre as que são orientadas 'estrategicamente para o sucesso' e as que são orientadas para a construção de um 'entendimento mútuo'. 
Estas últimas se baseiam em um acordo no qual as partes interessadas fiquem ambas satisfeitas. Portanto, na medida em que os participantes na interação desejam apenas ser bem sucedidos em seus interesses individuais, criarão 'estratégias' para alcançar seus objetivos, 'influindo externamente' para atingir o sucesso. Podem, de acordo com a aceitabilidade, no momento histórico, fazer uso desde meios mais rudes até os mais sutis como a sedução. De qualquer forma, o indivíduo orientado apenas para o sucesso tentará interferir externamente sobre a decisão do interlocutor que passa a ser seu 'adversário', e não colaborador.

A coordenação das ações de sujeitos que se relacionam dessa maneira, isto é, estrategicamente, depende da maneira como se entrosam os cálculos de ganhos egocêntricos. O grau de cooperação e estabilidade resulta então das faixas de interesses dos participantes (HABERMAS, 1989, p. 165).

A outra forma de interação seria o 'entendimento mútuo', o 'agir comunicativo'. Esta implica a negociação de um acordo que não deve ser imposto ao interlocutor por uma intervenção externa, seja pela força ou por manipulação. $O$ acordo assenta-se sempre na formação de um consenso, o qual é alcançado através do entendimento comunicativo. Esse entendimento mútuo pressupõe ganho para ambas as partes interessadas e não apenas para quem conseguir colocar de maneira mais atrativa para o grupo os seus próprios interesses.

Em ambos os casos, a estrutura teleológica da ação é pressuposta na medida em que se atribui aos atores a capacidade de agir em vista de um objetivo e o interesse em executar seus planos de ação. Mas o modelo estratégico da ação pode se satisfazer com a descrição de estruturas do agir imediatamente orientado para 0 sucesso, ao passo que o modelo do agir orientado para o entendimento mútuo tem que especificar condições para um acordo alcançado comunicativamente ( HABERMAS, 1989, p. 165).

Não existe uma polaridade estanque entre essas duas formas e sim um continuum. Algumas práticas discursivas favorecem mais uma forma do que a 
outra, da mesma forma que todo agir comunicativo também contém em si uma estratégia de argumentação que está implícita na própria estrutura lingüística.

$\mathrm{Na}$ interação entre publicidade e consumidor acontece uma argumentação por parte dos produtores do anúncio, mais claramente orientada 'estrategicamente para o sucesso' e não para o 'entendimento mútuo'. Nessa tentativa de criar e apresentar publicamente os consumidores, os produtos e as instituições, são elaboradas identidades ou personalidades para todos os participantes dessa interação. Todas essas identidades serão construídas no discurso que é orientado para a obtenção do sucesso (através de interferência externa). Seja ele a venda dos produtos/serviços, a lembrança da marca na mente dos receptores do anúncio etc.

As identidades criadas dessa forma não podem ser conflitantes, tem que ser complementares, pois todos fazem parte do mesmo 'estilo de vida e comunidade de consumo'. Poderia ser buscada uma comparação entre Habermas e Perelmann (2002). A interação orientada 'estrategicamente para o sucesso' seria, grosso modo, o discurso persuasivo, claramente buscando manipular o interlocutor em função de obtenção de resultado desejado em benefício próprio, no caso da publicidade - vendas, lembrança da marca. Já a interação orientada para um acordo, 'conseguido consensualmente', se aproximaria mais do 'convencer' de Perelmann, que parte de argumentos teoricamente úteis a todos.

Para demonstrar de que forma esse percurso, orientado estrategicamente para o sucesso, ocorre nos anúncios dos dois países com o intuito de apoiarem suas narrativas publicitárias, é que serão pesquisadas desde formas sintáticogramatical, assim como fraseologismos ou imagens lingüísticas e visuais escolhidas de forma a ativar determinados frames ou scripts dos leitores, ou como a ACD sugere "... qualquer nível de organização pode ser relevante para a análise crítica..." (FAIRCLOUGH, 1995, p.7) ${ }^{10}$.

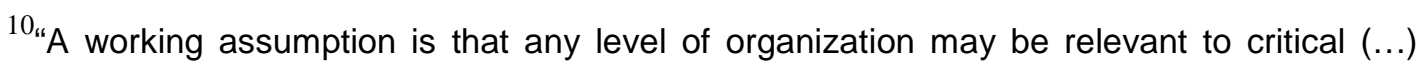
analysis" 
Para isso serão levantadas algumas categorias de análises propostas pela ACD que podem nos levar a esmiuçar os anúncios de forma a demonstrar a quais inventários perceptuais os anunciantes desejam ser ligados na mente do consumidor e o que isso pode indicar, quando analisado criticamente. Dentro do arcabouço de categorias propostas pela ACD esse trabalho usa: a análise dos mecanismos de coesão que aparecem na superfície textual, tais como os operadores argumentativos que nos permitem perceber a orientação argumentativa dada pelos produtores dos anúncios, qual ordem de importância é estabelecida para os enunciados, sua seqüência lógica; assim como as transformações sintático-gramaticais; índices de avaliações lexicais; fraseologismos; índices de polifonia e outros que serão discutidos abaixo.

Como a realidade é uma possibilidade do vir a ser, ela é construída a partir da negociação de sentidos, de acordo com o momento histórico, social, cultural, também por intermédio de textos. Defendemos, porém, que é impossível que uma análise textual seja capaz de elucidar todos os sentidos de um texto. Não existe 'a verdade' em um texto, mas sempre possibilidades de acordos dentro das circunstâncias que são vivenciadas como possíveis pelos interlocutores, no momento da produção textual para a construção dos sentidos.

O que procuramos estudar é o texto como resultado de um processo de produção multimodal, que procura interferir estrategicamente no processo de negociação de sentidos entre seus produtores e possíveis leitores, interferindo, dessa forma, na criação ou reprodução de novas significações dentro do espaço de vivência dos indivíduos. E o que eles deixam aparecer que pode ser próprio de cada país, no nosso caso a Alemanha e o Brasil. Se é que isso ocorre.

Espera-se, com esse trabalho, contribuir positivamente para a compreensão da construção de textos que envolvem um determinado público, levando-se em conta os tipos de acordos feitos entre os integrantes de uma mesma comunidade, como estes acordos são percebidos nas narrativas publicitárias e como podem ser detectados utilizando-se a Análise Crítica do Discurso, justamente porque esta admite como embasamento teórico para a análise qualquer nível de organização que se mostre relevante para uma análise crítica. (FAIRCLOUGH, 1995). 


\subsection{Categorias de análise da ACD}

As categorias para a análise lingüística levantadas abaixo seguem os parâmetros da ACD, expostas em Fairclough, Fowler; Kress e van Dijk . Os outros autores discutidos ao longo do trabalho se fizeram necessários para que essas categorias pudessem ser aprofundadas como: Ducrot (1987), Vogt (1989), Polenz (1985), Maingueneau (1997), Charaudeau (2006), Pörksen (1997).

Além destas categorias, foram incluídas categorias que servem para analisar que tipo de argumentação é feita por intermédio da composição da imagem. Para isso foram utilizados, principalmente, os autores Kress; van Leeuwen (2001), Dondis, 2003 e Joly (2005).

$\mathrm{O}$ ato de 'desconstruir' a forma de organização destes textos compostos por vários sistemas semióticos permite uma abordagem investigativa do que é dito nas entrelinhas desse complexo. É a investigação dessas 'entrelinhas' que permite a comprovação de que o texto é uma espécie de iceberg do qual o leitor vê apenas a ponta, e, se este pretende interagir com o primeiro, deve preencher os sentidos que permanecem abaixo dessa superfície. Se esse preenchimento é feito de forma mais ou menos consciente, vai depender da forma como esse leitor detém e sabe colocar em uso os mecanismos de interpretação do que 'lê', possibilitando uma visão crítica e participativa. Instrumentalizando-se, portanto, contra seduções manipulativas de textos que visam a reforçar situações de dominância.

Wittgenstein (1984) já afirmava que a palavra só adquire significado no contexto da proposição, pois uma mesma seqüência de sons adquire múltiplas significações, de acordo com a necessidade de comunicação na qual é expressa. Por isso não basta conhecer as palavras e as regras gramaticais, tem-se que saber como, quando, onde e por que elas estão sendo usadas Não basta conhecer os signos, tem-se que 'reconhecê-los' de acordo com as condições de uso. Portanto, compreensão para o filósofo não é uma operação puramente psicológica, mas uma operação-no-mundo. 
Qualquer texto é sempre construído em função de um possível efeito sobre seu ouvinte/leitor. Coloca-se, portanto, a construção de textos, tanto na produção ou recepção, em termos de estratégias a serem perseguidas de acordo com objetivos de ambas as partes. O raciocinar não é determinado por sua relação com o real (desse modo, a racionalidade seria reduzida a uma faculdade de reconstrução da verdade), mas pela intermediação de um conceito: o toque pragmático dado à racionalidade implica que as estratégias sejam encaradas como relacionando-se a valores e isso é uma característica essencial da dependência contextual do sentido discursivo. Como as estratégias são escolhas, elas indicam a preferência por determinados modos em detrimento de outros, também possíveis, no leque de escolhas, o que implica um apagamento do que não é escolhido.

O texto torna-se um todo coeso e coerente quando apresenta, na escolha de cada elemento que o compõe, uma relação de interdependência sintática (mecanismos que ligam os termos e as orações entre si), semântica (sentido dos elementos lingüísticos utilizados e dentro de um contexto) e pragmática (relacionamento dos interlocutores entre si e dentro de contexto de uso adequado). São esses recursos que permitem o desenvolvimento compreensível das proposições dos enunciados e do encadeamento lógico entre eles. A análise desses processos procura explicar como os elementos que se materializam na superfície textual são capazes de dar determinados sentidos lógicos às seqüências escolhidas para co-ocorrerem nessa ordem e dessa forma.

O conhecimento partilhado é parte fundamental nesse processo de estruturação/interpretação. Existem processos cognitivos envolvidos na interpretação que serão responsáveis pela criação de sentidos de acordo com o contexto onde o texto ocorre. São eles que proporcionarão aos interlocutores a possibilidade de "... criar um mundo textual que pode ou não concordar com a versão estabelecida do 'mundo real'” (KOCH \& TRAVAGLIA, 1991, p. 30). A esse mecanismo dá-se o nome de 'coerência'. Enquanto a coesão se expressa no nível superficial da língua, a coerência busca um sentido, mesmo quando o texto não 
parece tê-lo. É a confluência de relações sintáticas, semânticas, pragmáticas e cognitivas que vão fornecer sentidos coerentes ao texto.

Se pensarmos em termos de publicidade, muitas vezes o único elemento que fornece coerência necessária para uma possível interpretação do texto é o fato de os participantes da interação saberem tratar-se de uma publicidade.

Enfim, o objetivo do uso das categorias de análise abaixo citadas é possibilitar a demonstração dos objetivos aos quais nos propusemos no início do trabalho, ou seja: comparar as organizações argumentativas em alguns anúncios dos países Brasil e Alemanha. Apresentam eles diferenças/semelhanças quanto à construção retórica e temática? Essas possíveis diferenças e semelhanças na construção dos sentidos refletem diferentes acordos culturais nos quais se apóiam ambas as comunidades?

As categorias de análise serão dispostas da seguinte maneira:

- $\quad$ categorias gramaticais:

=> operadores argumentativos;

$=>$ transformações sintáticas:

•transformação passiva, •nominalizações, • outras transformações.

- categorias semântico-pragmáticas:

$=>$ ethos;

=> modalidade lingüística;

=> índices de avaliação lexical:

-relexicalização, •palavras de plástico, •expressões fraseológicas;

=> índices de polifonia: pressuposto, subentendido e intertextualidade.

- $\quad$ categorias da linguagem visual.

\subsubsection{Categorias gramaticais :}

\section{$>\quad$ Operadores argumentativos;}

Koch (1992, p. 29), escrevendo sobre a fundamentação da busca por elementos que demonstrem a estratégia usada pelos falantes perante seus enunciados, afirma, juntamente com Ducrot (1987), que toda língua traz 
"mecanismos que permitem indicar a orientação argumentativa dos enunciados". Ducrot (1987) dá a esses mecanismos, acima citados, o nome de 'operadores argumentativos'. Estes são certos elementos lingüísticos usados a fim de relacionar as proposições entre si, de forma a tornar possíveis seus encadeamentos, possibilitando estabelecer ordens de importância, com o intuito de direcionar o leitor/ouvinte a perceber a força dada às proposições. Ao mesmo tempo, esses mecanismos 'indicam' como deve ser a construção dos sentidos estipulados pelos enunciadores, buscando fazer com que o interlocutor chegue à conclusão apontada por eles. Para se apreender os sentidos do enunciado, é necessário que se persigam os operadores como 'pistas' inscritas na enunciação. (VOGT; DUCROT, 1989, KOCH .1995, 1996, 2004, POLENZ, 1985). São estas pistas que perseguiremos nos anúncios, em busca de desvendar que tipo de orientação argumentativa é construída pelos produtores.

Os operadores podem ocorrer em função:

$>$ de demonstrar a relação que liga alguns aspectos do conteúdo do enunciado a elementos de espaço e tempo, por exemplo, no texto de Nando Reis usado pela Pfizer: 'Faz muito tempo você implicava comigo, mas hoje eu...

$>$ da relação lógico-semântica entre as orações, como no título do anúncio da BASF: 'se a gente não mostrar 'isso' (a BASF faz parte), você nem percebe'. Podem ser relações de causalidade, condicionalidade, finalidade etc.;

$>$ de como a estratégia discursiva é organizada de forma a reforçar os argumentos que estão sendo usados, buscando a concordância do interlocutor. Isso pode ser feito, por exemplo, por uma 'classe argumentativa', na qual os argumentos vão sendo somados uns aos outros, ou por um operador argumentativo do tipo 'mas' que opõe enunciados com vetores diversos;

> da ordem como os argumentos devem ser estabelecidos. Um exemplo é o anúncio publicitário de um aparelho de barbear, Gillette G2 com duas 
lâminas: 'A primeira faz tcham e a outra tchum', indicando a seqüência do corte das duas lâminas.

Como pode ser percebido, não se consideram operadores argumentativos apenas conjunções do tipo lógico-semântico que são as responsáveis pelas relações entre frases subordinadas ou que relacionam as frases coordenadas. Consideram-se operadores argumentativos marcas, 'pistas' que são usadas estrategicamente para possibilitar encadeamentos de segmentos textuais de qualquer extensão que levem à criação de sentidos, como os demonstrados acima, de espaço-tempo e de como os argumentos são ordenados.

Chama-se a atenção para o uso recorrente da parataxe em anúncios publicitários. Usaremos esse termo no sentido dado por Dubois (1995, p. 456): “...um processo sintático que consiste na justaposição das frases, sem explicar (...) a relação de dependência que existe entre elas....." Em anúncios publicitários, isso ocorre, não só pela limitação do espaço físico e temporal, mas também em função da facilidade com que o leitor assimila as unidades de informações contidas entre pontos finais, como já foi discutido anteriormente.

Gostaríamos de frisar que, com o uso acentuado da parataxe, o texto adquire, muitas vezes, uma maior ambigüidade. Se o uso de operadores argumentativos é um dos mecanismos responsáveis pelo encadeamento e, portanto, pela orientação para um ponto de vista do pensamento, o fato de eles estarem ausentes faz com que os leitores tenham que construir mais inferências para lhes dar sentidos. (POLENZ, 1985).

Ao mesmo tempo, essa ausência permite e estimula que cada leitor também construa, de acordo com seus próprios scripts, tanto culturais quanto individuais, seus próprios sentidos. A ambigüidade é bem-vinda para que os leitores possam adequar a seus próprios scripts o preenchimento de lacunas com maior liberdade. É como se ficasse à disposição do próprio leitor o emocional necessário a ser acionado para promover a ligação afetiva entre ele e o anúncio. Por isso o cuidado tão grande com respeito ao inventário perceptual usado para chamar essa consonância cognitiva. 
Como uma forma de resolver o problema da ambigüidade ou de condensamento demasiado em determinados enunciados, Polenz (1985) aconselha o leitor a construir paráfrases e, dessa forma, tentar perseguir as intenções de seu produtor. Com essa metodologia, podem ser revertidos processos apassivação, de nominalizações, que impedem uma boa compreensão do enunciado ou ser percebida a necessidade de preenchimentos de lacunas, deixadas pela ausência de operadores argumentativos em enunciados elaborados com o uso de parataxe. Como se sabe, cada grupo de operadores argumentativos orienta a construção de sentidos para diferentes conclusões.

Uma explicação que se faz necessária é a da diferença entre os operadores 'aber ' e 'sondern' alemão entre si e o 'mas' brasileiro. Vogt; Ducrot (1989) estudam essa distinção, que ocorre mais claramente na língua alemã do que na língua portuguesa.

Em alemão, existem dois vocábulos para dois sentidos diversos. Em língua portuguesa, essa diferença de sentido não se mostra mais na ortografia. Os dois sentidos são expressos apenas pelo operador 'mas'. Porém, segundo esses autores, em português, continua ocorrendo a diferença no sentido lógico que une as proposições. Essa proposta é aqui discutida, brevemente, para justificar algumas opções feitas durante o processo de tradução dos anúncios alemães para o português e também para justificar a escolha do operador para possibilitar a paráfrase de enunciados unidos por parataxe.

O operador 'sondern', tem a função de 'retificação' de uma negação feita no enunciado anterior. Com isso a primeira proposição negativa seria uma "encenação de um diálogo com um interlocutor imaginário" (VOGT \& DUCROT, 1989, p. 112). Já a segunda proposição seria sua correção. Exemplo: "Er ist nicht intelligent, sondern klug" ou em português: "Ele não é inteligente, mas esperto" (ibidem, 104). A primeira proposição seria a repetição negativa de um possível diálogo ocorrido anteriormente na afirmativa - "Ele é inteligente". - e a segunda a introdução de sua correção.

O operador 'aber' não é dependente de uma negação anterior. Ele se encarrega de desviar o rumo da conclusão que foi sugerida na proposição 
anterior. É como se a argumentação viesse com um vetor e fosse desviado para outro não previsto anteriormente. A partir desse desvio, a conclusão que deveria ser num determinado sentido, segue em outro, muitas vezes oposto. Há um exemplo dado por van Dijk (1992) a respeito do discurso sobre o racismo que exemplifica muito bem o uso do 'mas/aber': - "Eu não tenho nada contra negros morando no meu edifício, mas ...". Embora, a princípio a proposição pareça levar à conclusão de neutralidade, demonstra ser apenas uma tentativa de amenização para os argumentos que se seguem que levam à reorientação da conclusão que é: "Não quero, não acho bom, resisto ao fato de ter negros morando no meu edifício" (ibidem).

Essa discussão foi necessária porque ao parafrasear o título do anúncio da BASF: "Unsichtbarer Beitrag. Sichtbarer Erfolg" - Invisível contribuição. Visível sucesso. -, o operador escolhido para preencher a lacuna provocada pela parataxe foi o 'aber'. O motivo será discutido na análise (p.169).

Gostaríamos de destacar a "classe argumentativa" como um dos operadores mais recorrentes no material analisado, tanto em alemão quanto em português. Por exemplo, no trecho abaixo, ocorre uma classe argumentativa.

A BASF colabora: (1.) com plásticos, (2.) para' um maior desempenho (3.com) inúmeros setores da indústria (4.) para que' produtos de melhor qualidade façam parte do seu dia-a-dia'. (Este enunciado aparece no primeiro anúncio da BASF brasileira.)

Segundo Koch (1995), o operador argumentativo 'classe argumentativa' é a utilização de um grupo de argumentos levando à mesma conclusão. Funciona como um vetor lingüístico por intermédio de uma espécie de lista, onde os vários argumentos são usados para direcionar o leitor à conclusão desejada pelo enunciador.

O vetor que se impõe para a conclusão é que o leitor é conduzido a avaliar positivamente a atividade da BASF por sua contribuição em vários fatores.

Como foi discutido acima, não são apenas elementos relacionais que são considerados como responsáveis por proporcionar uma orientação na 
argumentação. A classe argumentativa é uma forma de disposição de argumentos que funciona, por si própria, como operador.

Além disso, existem vocábulos que não se enquadram na classificação tradicional das dez classes gramaticais propostas pela N.G.B. e que tem papel importante na orientação da argumentação. Cunha (1976, p. 376) define-as como: "Certas palavras, por vezes enquadradas impropriamente entre os advérbios, passaram a ter com a Nomenclatura Gramatical Brasileira, classificação à parte, mas sem nome especial."

Ele dá conta desses elementos como sendo: denotadores de inclusão (até, inclusive, mesmo, também etc.); de exclusão (apenas, salvo, senão, só etc.); de realce (... é que, só etc.); de retificação (aliás, ou antes, ou melhor, isto é etc.); de situação (afinal, agora, então etc.)".

\section{> Transformações sintáticas;}

A língua oferece um leque de opções possíveis, a fim de criar os sentidos, portanto, a escolha de uma forma gramatical é a materialização de determinada experiência social/individual que se concretizou. As vozes ativa, passiva, as nominalizações ou outras transformações sintáticas são possibilidades de diferentes formulações lingüísticas sobre os mesmos acontecimentos, idéias etc. e isso implica que essas possibilidades existam numa relação de 'pares de variantes complementares', isto é, faz com que todas estejam à disposição do falante como opções para as formulações, (POLENZ, 1985). Porém, as opções feitas pelos falantes não estão isentas de interferência nos sentidos que são veiculados pelos enunciados. Isso tem implicações quanto ao tipo de realce que se deseja dar aos elementos dentro do enunciado. Por exemplo:

na forma como os agentes envolvidos estão representados, se para isso são materializados processos de ação, cuja característica é o uso de verbos que pedem um agente que age em direção a um objetivo, buscando algum tipo de interferência - esquema tipo: sujeito + verbo + objeto -; 
ou processos de relação que são marcados por verbos como 'ser', o que provoca a perda da noção de agentividade;

$>$ ou mesmo supressão da noção de tempos, modos verbais ou da modalização tão necessários para situar acontecimentos e indivíduos historicamente.

Desse ponto de vista, muitas vezes, a forma escolhida para se expressar o que se quer dizer deixa de ser apenas uma opção criativa individual e assume também um aspecto social, cultural, histórico etc. Torna-se, pois, de extrema importância analisar por que são escolhidas determinadas formas gramaticais e não outras que também se encontram à disposição do usuário para veicular determinados sentidos.

\section{- Transformação passiva}

A voz passiva diferencia-se da ativa em três aspectos. Tomemos o seguinte exemplo: Voz ativa: $\quad \mathrm{X}$ manifesta $\mathrm{Y}$. =

$$
\text { Voz passiva: } \quad \text { Y é manifestado (por } \mathrm{X} \text { ). }
$$

1- Na voz passiva, a predicação não é feita sobre o agente da ação $X$, mas sobre o paciente $Y$, e isso muda o foco de importância que se dá aos componentes da frase;

2- a voz passiva possibilita que o agente da ação seja omitido. $O$ agente permanece, porém de forma implícita e não com o foco de atenção que recebe na ativa;

3- na voz ativa, a predicação é vista do ponto de vista do agente, sendo, nesse caso, uma ação. O agente é responsável pela ação em relação a um objeto. Na passiva, perde-se essa característica acional. Pode também ser vista do ponto de vista do objeto e passa a ser um processo ao qual o paciente se submete. Nos dizeres de Polenz (1985, p. 183), "... a classe de predicado semântico, que na frase ativa é AÇÃO, na passiva, fica como pano de fundo em benefício da classe de predicação PROCESSO 
(Vorgangspassiv)"11. A frase ativa admite os dois pontos de vista. Já na passiva, com a qual se predica a partir do objeto, existe a intenção de que o processo predomine sobre a ação, pois o sujeito/agente é implícita ou explicitamente apagado.

Essas opções não ocorrem aleatoriamente. Esse deslocamento da atenção do paciente para o agente - e vice-versa - por processos de transitividade possibilita que o enunciador determine a prioridade/importância do tópico a ser tratado, já que se pode apagar sujeitos ou ações que não devam aparecer, desqualificar sujeitos indesejados, realçar ou, simplesmente, apagar todo o tópico.

Por exemplo, vários livros escolares de História do Brasil utilizam a voz passiva para falar de atos ditatoriais durante o período de 1964 a 1989, elidindo ou ocultando os agentes responsáveis por eles. Ex.: "Os brasileiros foram impedidos de escolher os governantes do país". "Os meios de comunicação foram censurados." (MARSICO, 2000, p. 63)

O próprio Polenz $(1985,192)$ fornece exemplos de como acontecimentos como golpes para tomada de poder, guerra e outros fatos determinados por poderes de grupos políticos e socioeconômicos concretos, que são resultantes de relações humanas institucionais, aparecem como "catástrofes patológicas, místicas, meteorológicas" porque a opção é pelo apagamento e a conseqüente 'naturalização' dos acontecimentos.

Segundo esse autor, a voz passiva já é usada, na Alemanha, desde o século XI como uma forma cortês de preservação de face, em tipos de frase com o pronome 'man' que equivale ao apassivador 'se' na língua portuguesa. E serve, até hoje, como uma forma de não enfrentamento direto. $O$ falante não tem intenção de polemizar ou dizer claramente o tipo de ação cometida pelo agente. Opta-se, então, pela transformação para a passiva, e, por intermédio do afastamento do agente, expressa-se uma certa vagueza quanto aos agentes diretos da ação. De acordo com o mesmo autor:

\footnotetext{
11 "Die semantische Prädikatsklasse, die im Aktivsatz HANDLUNG ist, wird im Passivsatz zugunsten der (...) Prädikatsklasse VORGANG in den Hintergrund gerückt ("Vorgangspassiv)".
} 
... das três características semânticas da passiva a falta de agente pode ser aceito como o motivo mais forte e mais freqüente para o uso das frases na passiva. Isso vale também para as assim chamadas formas substitutas da passiva (ibidem, p. 185) ${ }^{12}$.

No caso da BASF alemã, há opção pelo uso da voz passiva quando se refere aos outros que não a BASF. A opção pela voz ativa quando se refere a si própria, com o uso do sujeito na primeira pessoa. Não se trata de uma questão de estilo, mas de um claro realce do papel de liderança e competência que a BASF deseja vincular a sua imagem e não à dos outros.

\section{- Nominalização}

Nominalização é um processo por intermédio do qual os nomes são criados a partir de sentenças ou de parte delas, e para as quais, na maioria das vezes, já existem conceitos à disposição dos usuários. Funcionam como possibilidades de formas substitutas da transformação para a voz passiva. Portanto, entram na relação de complementaridade entre as vozes ativa/passiva/nominalizações. Polenz (1985) chama a atenção para o fato de que essas formas de conversões, nas quais se afasta do centro de atenção o agente do enunciado, estão em moda na Alemanha e pelo que pudemos perceber por nossas leituras de Fairclough (1999), o mesmo acorre em outros países.

Esse processo acaba provocando um uso mais ou menos inconsciente dessas formas, entre todos os falantes. $E$ isto não está mais restrito, como anteriormente, a algumas situações de interação, como, por exemplo, discursos acadêmicos. Há o afastamento sistemático da ação humana em direção a obras 'fatídicas da natureza', inevitáveis, com a conseqüente naturalização de fatos, fenômenos, relações, objetos que são resultado de relações históricas, sociais, culturais, locais.

Esse afastamento é no sentido de que nos tornamos alheios à percepção de que podemos, enquanto seres humanos, agir concretamente sobre algo que

\footnotetext{
12 "... kann von den drei semantischen Eigenschaften des Passivs (...) die Agentlosigkeit als das stärkste, häufigste Motiv für den Gebrauch von Passivsätzen angenommen werden. Dies gilt auch für die sog. Ersatzformen des Passivs".
} 
necessita de intervenção concreta de indivíduos humanos, para que seja mudado. Não é à toa que as leis, os conhecimentos, tanto o científico como os de senso comum, sejam elaborados de forma tão abrangente e sem agentes claros.

Isso, segundo Polenz (1985), é feito para que este tipo de dizer, essa materialização lingüística, se refira à maioria dos indivíduos, mas também para que não ocorra aos indivíduos envolvidos nesses processos, a possibilidade de pensar em formas concretas de atuação que levem a mudanças. Impede questionamentos a respeito de quem fez essas leis, criou esses conhecimentos, em benefício de quem, onde, quando. Impede, inclusive, que se detectem as verdadeiras razões históricas, econômicas, sociais etc. de acontecimentos, fatos políticos etc.

De acordo com esse mesmo autor, a tendência do uso desse 'condensamento de sentidos' fica mais forte em língua alemã a partir do lluminismo, quando se começa a escrever em estilo científico. Ele também identifica o surgimento dessa forma de se expressar com o tipo de sociedade que começou a surgir a partir dessa época. Uma sociedade industrializada, impessoal, massificada, na qual o "agente de ações" deixa de ser levado em consideração intencionalmente. E onde o foco de atenção é transferido para o processo.

É interessante notarmos que é justamente nesse período a instauração do projeto de modernidade, que propunha soluções que servissem a todos. Projeto que mais tarde se revelou amargo em sua tentativa de universalizar soluções.

Essa forma de derivação acima citada provoca o efeito de um enfraquecimento dos itens envolvidos na frase, pois com a criação de um nome para indicar processos, eventos, surge uma "impessoalidade" advinda desse apagamento de possíveis agentes. "Mais freqüentemente, em sentenças complexas da linguagem escrita, os participantes desaparecem completamente e têm que ser 'entendidos' a partir do contexto" (FOWLER; KRESS, 1989, p. 207).

Isso, às vezes, provoca dificuldade de compreensão, tendo em vista que muitas informações que poderiam ser necessárias para a interpretação são apagadas. É um processo extremamente freqüente em publicidade. Isso, tanto por causa do espaço exíguo da publicidade, quanto pela intenção de apagamento de 
possíveis processos conflituosos e indesejados da produção, que não precisam ou não devem - ser lembrados aos consumidores, como também para envolver o produto numa certa aura de mistério. Além de possibilitar o que foi dito acima: que cada leitor tem maior possibilidade de preencher lacunas com seus scripts de vida.

Outras características importantes do uso de nominalizações é que elas anulam o uso de modalização e tempo verbal (ibidem, 1989). Retira-se, dessa forma, a possibilidade de contextualização histórica, o que impede a inserção em uma discussão maior.

Segundo Polenz (1985), esse processo de nominalização permite que o enunciado carregue mais incertezas e o nível de polissemia aumente. A compreensão da informação torna-se muitas vezes difícil ou comprometida para o ouvinte/leitor por conta desse excesso de informações condensadas em nomes. Para resolver esse problema, o autor aconselha que sejam feitas paráfrases para tentar diminuir esses índices de incertezas. Baseado nessa orientação, este trabalho faz uso desse processo de paráfrase.

De acordo com o que foi pesquisado nos anúncios do corpus, podemos adiantar o enunciado "Inovação e cuidado com o futuro" do anúncio 1 da BASF brasileira. Temos, aí, duas nominalizações que deixam perceber aquela 'vagueza' proposta pelos autores. A BASF inova exatamente o quê? Para quem? O futuro está em perigo, por quê? Etc. E ao mesmo tempo acionam scripts de pesquisa competente e de solidariedade.

\section{- Outras transformações}

Fowler; Kress (1989) chamam a atenção para outros tipos de transformações, que servem de categoria para esta análise, pois interferem no modo de criação de determinados sentidos:

> frases negativas, que segundo Fowler; Kress (1989, p. 209) "limitam a quantidade de informação que o falante está preparado para liberar", isto é, o enunciador é que determina qual informação vai ser negada em detrimento de outra. Além do fato de trabalhar com a pressuposição da 
existência da afirmativa. Este recurso é muito pouco usado em publicidade, já que apenas se louva, não se questiona nada;

$>$ transformações de frases subordinadas em principal, de deslocamento lexicais dentro da frase, o que provoca mudança de foco do tópico da frase, dirigindo nossa atenção para o que está sendo realçado. Recurso usado em todos os anúncios pesquisados e que será discutido na medida em que aparece.

\subsubsection{Categorias semântico-pragmáticas}

\section{$>$ Ethos}

Quando Aristóteles esquematizou os passos por intermédio dos quais um orador procura influenciar um auditório, ele concluiu que o discurso não era composto apenas de uma ponderação racional sobre determinado tema. Não bastaria para este orador compor a sua fala, apenas de acordo com regras estipuladas pela gramática. A fala do orador envolve três dimensões que são inseparáveis. O logos, pathos e ethos.

- O logos é responsável pela ponderação racional que se faz a respeito de um tema. Isso é construído a partir do encontro e da apresentação de argumentos que possam ser considerados razoáveis, de sua organização e colocação em material lingüístico correto e agradável. É a parte que trabalha o convencimento racional do interlocutor. Supõem-se, portanto, um interlocutor, também, capaz de interpretar racionalmente.

- O 'pathos', esta dimensão é reservada à reação demonstrada pelo auditório ou como o ouvinte é conduzido, pelas escolhas do orador, em relação às duas outras dimensões, a entrar em sintonia com a intenção deste último, referese à empatia do auditório com o orador.

- 'Ethos' é um termo usado na retórica antiga que se refere à dimensão do discurso que deixa transparecer o que as escolhas feitas pelo orador demonstram implicitamente sobre si próprio, a ponto de interferir na avaliação dos ouvintes, independentemente, inclusive, $d$ os argumentos virem muito bem colocados. $O$ 
ethos é o que se deixa transparecer aos outros pela sua forma de colocar-se em público ao assumir a fala, mas ao mesmo tempo é o que os falantes crêem ver da imagem de si próprios e dos ouvintes.

O orador constrói seu discurso dessa forma porque tem em mente um auditório particular. Ele constrói mentalmente, conscientemente ou não, um indivíduo/grupo ideal, baseado na suposição do que ele acha que o auditório pensa de si próprio e do orador. Tenta se comportar verbal, corporal e afetivamente da maneira que seria mais adequada para o momento. São elementos informativos, maneira de ser e agir, construídos pelo falante e pelo ouvinte/leitor, a partir de valores de referência com os quais os indivíduos vivem.

Estas opções demonstram que o ethos se refere, não só, a determinados 'tipos' de escolhas lingüísticas, mas, também, a comportamentos apresentados pelos falantes, aos hábitos e apresentação física e psicológica perante o auditório.

O que foi apresentado acima, como sendo três dimensões facilmente separáveis no discurso, na verdade não ocorrem de maneira estanques. As três ocorrem entrelaçadamente, e é esse imbricamento que vai proporcionar 'olhares cruzados' entre o lingüístico, o visual e o emocional, que permite compor significações nem sempre perceptíveis em nível consciente.

Nossa preocupação será, mais explicitamente, com a primeira e terceira dimensão, na medida em que demonstram opções do enunciador, que deixam transparecer diferentes acordos a partir dos quais as argumentações são construídas, tendo em vista diferentes públicos, o alemão e o brasileiro.

Enquanto a retórica antiga utilizava a noção de ethos como parte integrante de um sistema que possibilitava o convencimento do interlocutor, a ACD utiliza a noção de ethos porque assume que a linguagem é parte integrante de uma articulação com outras práticas sociais detentoras de diferentes códigos semióticos, cujas significações emergem na linguagem (FAIRCLOUGH, 1999, 2001). A interpretação é dependente de uma avaliação valorativa, consciente ou não.

Maingueneau afirma: "A eficácia destes "ethé" se origina no fato de que eles atravessam, carregam o conjunto da enunciação sem jamais explicitarem a sua 
função" (1997, p. 45). É, por exemplo, tudo o que vem acompanhado com a figura do médico, sem que este tenha a necessidade de explicar o porquê de suas ações, ou a sua posição de falante diante do paciente, seu poder de perguntar em relação ao paciente, a autoridade com que fala, que se supõe saber mais do que o paciente, o seu papel solidário em relação ao paciente, a roupa que veste, o seu lugar na hierarquia do serviço de saúde etc.

É o poder que o discurso tem de suscitar a crença de que ele pode falar dessa posição, que é diferente da posição da fala do paciente. Assim como a fala do professor é diferente da do aluno etc. Esse apanhado de características físicas, sociais, psicológicas etc., que os ouvintes ou leitores vêem consciente ou inconscientemente como sendo parte da figura do enunciador, é criado em função da maneira como este último se coloca diante do seu interlocutor e depende de como a comunidade recorta e articula os traços avaliativos que thes servem como orientação para colocar-se em seu mundo.

Portanto, os interlocutores, ao se interpelarem devem acionar um conjunto de imagens/idéias que correspondem ao ethos que fazem de si e do outro, e esses interlocutores têm que ter conhecimento, pelo menos da existência desse lugar de 'fala' para poder reconhecer no outro o ethos que o define.

Maingeneau ainda chama a atenção para o uso que a publicidade faz disso:

... esta concepção da eficácia discursiva é constantemente integrada pelos textos publicitários, que mostram (...) aquilo que provavelmente constitui a tentativa de toda a formação discursiva: convencer consiste em atestar o que é dito na própria enunciação, permitindo a identificação com uma certa determinação do corpo (Ibidem, p. 49).

É o que a publicidade faz com determinadas características do ser humano. Por exemplo, quando quer realçar o aspecto maternal, faz uso de todos os símbolos que levam ao ethos de 'mãe protetora': mulher não muito jovem, criança feliz ao lado, atitude protetora, dona de casa zelosa, limpa e preocupada com a limpeza, aspectos de pureza angelical, feliz na cozinha, na casa etc.

É isso que Maingueneau chama de paroxismo. Podemos perceber esse mecanismo de paroxismo nos anúncios da BASF brasileira, quando o anunciante 
coloca um realce absoluto nos ethé do que acha que corresponde a indivíduos que se encontram em família feliz, como figuras parentais protetoras, filhos sorridentes, casa brilhante, bem cuidada etc. Nos anúncios dos anos anteriores, o uso do ethos de figura materna era mais acentuado. No ano de 2005, esse inventário foi compartilhado com outros componentes da família.

Segundo Charaudeau (2006), existiria para o indivíduo real, o locutor que assume a fala, que se expressa em uma identidade individual e social e uma identidade que constrói para si no discurso - uma identidade discursiva. "O ethos é o resultado dessa dupla identidade, mas ele termina por se fundir em uma única" (ibid., 115). Por exemplo: existe uma identidade real - 'BASF' -, que é uma indústria responsável pela fabricação e pesquisa de produtos, com funcionários, fábricas, relações econômicas etc. e uma identidade construída por intermédio do discurso usado nos anúncios, e de outros mecanismos que não serão discutidos neste trabalho.

A identidade da BASF passa a ser a conjunção daquilo que a BASF é, mais a imagem que constrói para si por intermédio do discurso, na tentativa de fazer com que o leitor dos anúncios a veja com determinadas características positivas. Portanto, a BASF se apresenta como empreendedora, competente, mais a forma como o leitor a vê: a BASF é competente e empreendedora.

Só que tudo isso não acontece em um vácuo. Como já foi dito, existe uma identidade social. A realidade na qual está imerso esse locutor é determinada em grande parte pelas representações que circulam em dado grupo social. É o que Fairclough (2001, p.99) denomina de 'recursos dos membros' que são "... recursos sociais, (...) em que se baseiam a produção e a interpretação dos sentidos e como isso ocorre".

Existe, portanto, um 'ethos coletivo' (CHARAUDEAU, 2006), que faz com que os indivíduos avaliem-se, com base nos parâmetros determinados pelo grupo e estes se avaliem mutuamente, baseados em aspectos da identidade que os caracteriza enquanto grupos, ou o que se entende como pertencente ao grupo. Isso fica fácil de ver na publicidade da Pfizer. Há uma variação entre o ethos 
escolhido para se ligar ao personagem da narrativa alemã e da brasileira, que serão apresentadas e discutidas na análise.

Embora as categorias de análise de ethé propostas por Charaudeau (2006) sejam aplicadas à fala de políticos, achamos que podem ser aplicadas para auxiliar na análise dos anúncios.

A escolha da foto e do texto, a organização cuidadosa de ambos, o local de inserção do anúncio, a escolha dos valores referenciais sobre os quais se apóia a narrativa publicitária, todos esses 'cruzamentos de olhares' fornecem os ethé com os quais o anunciante deseja ser vinculado no espaço mental do consumidor do anúncio. Teremos então o ethos de credibilidade, competência, 'potência e poder', 'humanidade e solidariedade' etc. Esses dois últimos pares serão importantes para a análise dos anúncios publicados nos dois países. O ethos de solidariedade, segundo o autor, significa comunhão de semelhantes formas de pensar:

A solidariedade não é compaixão. A primeira se quer igualitária e recíproca; a segunda caracteriza um movimento assimétrico entre um indivíduo que sofre e outro que, apesar de não sofrer, está, no entanto, emocionado pelo sofrimento alheio (CHARAUDEAU, 2006, p. 163).

O ethos de humanidade demonstra a imagem do indivíduo capaz de "... demonstrar sentimentos, compaixão para com aqueles que sofrem, ..." (ibid., 148). Isso explicaria a incidência de anúncios de imagem solidária e humana das empresas que dizem desenvolver projetos em países ou comunidades carentes.

Quanto aos ethé de potência e poder, o autor coloca o primeiro como: “... uma energia física (...) nos remete a imagem de uma força da natureza" (ibid., p. 138). Pode ser expresso por figuras de 'virilidade sexual', explícita ou não. Pode ser encaixada aí a figura do herói mitológico, com energia própria suficiente para vencer obstáculos e desafios. O segundo ethos, de poder, refere-se ao resultado de "...uma ação coordenada que tem por finalidade a organização da vida coletiva" (ibid. p. 138). É um ethos que pertence ao grupo e não a indivíduos, possibilita 
empreendimentos coletivos, serve para sustentação, manutenção ou mudança do status quo.

Este trabalho faz uso dessa categoria de análise porque o corpus é composto por diferentes códigos semióticos, nos quais a composição visual do anúncio apresenta um peso tão grande quanto o lingüístico, ou até maior, já que é o que primeiro chama a atenção, o que permite a ocorrência desse cruzamento por excelência. Essa confluência de significados faz com que scripts sejam acionados sem que os leitores se dêem conta e, como já sabemos, é dessa forma que o convencimento ocorre mais facilmente.

Por exemplo, ao nos depararmos com a foto do anúncio 2 da BASF alemã um ser humano solto no ar, ligado ao topo de uma montanha por apenas uma corda -, é deflagrado todo um script de esportes de alto risco, o que provoca toda uma gama de associações, nas quais vários ethé, em relação aos anunciantes, são acionados.

O uso do ethos nesse anúncio se dá por intermédio do apelo a um script que representa situação de risco, perigo de vida ao qual um ser humano está exposto. A imagem poderia ser substituída por um ser humano, descendo as cataratas de Foz de Iguaçu, dentro de um caiaque, feito, logicamente, com derivados da BASF. O ethos usado seria o mesmo, o da potência individual, ancorado no ethos de credibilidade da BASF, responsável pelo fornecimento de materiais fidedignos, demonstrando competência. Isso, logicamente, terá que vir reforçado pelo texto lingüístico, ou haverá dissonâncias.

\section{> Modalidade lingüística}

O termo modalidade vem de modus, isto é, o modo, a atitude do falante, que se manifesta em relação ao conteúdo do que fala (DUCROT; TODOROV, 1972). O estudo da modalidade é a parte da lingüística que trata de construções específicas, ligadas ao contexto em que ocorrem, revelando relações pragmáticas e interpessoais entre os falantes e o modo como estes afirmam os valores que representam. 
São pistas pragmáticas que indicam atitudes dos enunciadores perante 0 que foi dito por eles, demonstrando seu grau de comprometimento e também em relação a seus interlocutores. É a possibilidade de se identificar em que grau ocorre esse engajamento. Por intermédio deste recurso, o falante pode comprometer-se de maneira mais ou menos enfática. Essa demonstração de atitude, sentimentos, ou quaisquer outras intenções, pode ocorrer por diversos mecanismos que servem de indicações que orientam para as conclusões desejadas pelo enunciador e para as quais os diversos argumentos podem servir. As atitude e intenções dos enunciadores também podem ser expressas por meios não verbais, como gestos, comportamentos, imagens etc. Na língua, elas podem ocorrer por intermédio de:

a) orações modalizadoras: "É lamentável que"...", "É possível que...", "É claro que...", "Eu acho ...";

b) advérbios modalizadores ou de enunciação (FOWLER et al. definem como advérbios sentenciais): felizmente, infelizmente, francamente,...;

c) tempos verbais como futuro do pretérito, subjuntivo...

Lakoff; Johnson (2002) também chamam a atenção para o termo 'Hedges', que seria "... modificadores, chamados delimitadores ..." e que serviria como uma espécie de escudo ao enunciador, quanto ao seu real comprometimento com o que foi enunciado. São locuções como: "por excelência, estritamente falando, tecnicamente, em um sentido importante..., um verdadeiro..., um tipo de..., bem... e muitos outros". (Ibid., p. 215).

Com esse tipo de estratégia o enunciador, pode excluir, delimitar, impor restrições sobre o potencial argumentativo, incluir, dar conotações mais ou menos generalizadoras para objetos, eventos, experiências, fatos em uma ampla variedade de categorias que servem para os fins desejados.

Embora essas locuções pareçam não ter muita utilidade, são instrumentos importantes para lapidar conceitos, determinar valores e, dessa forma, possibilitar a modificação de sua utilização, de acordo com a intenção do falante.

Polenz (1995, p. 196) vai tratar de 'hedges performativas', que ele identifica como expressões performativas não explícitas, pois são tão integradas e 
esperadas em determinadas circunstâncias que não há necessidade de expressálas. Como é o caso de performativos ocultos em modais utilizados em expressões de polidez: ex.: "Sou obrigada a recusar .../ Ich muss es ablehnen ... ", ao invés de 'eu recuso".

Fowler e Kress (1979), na gramática da modalidade, estudam outros aspectos que podem demonstrar esse comprometimento dos interlocutores como o uso do pronome pessoal 'nós', acionado pelo falante para falar em nome de si próprio e também em nome de outros.

Os pronomes são considerados dêiticos. Segundo Benveniste (1995, p. 280), os dêiticos são um grupo de signos que não têm referentes "com relação à 'realidade'". Esses signos que o autor chama de 'vazios' estão à disposição dos falantes para que possam ser preenchidos. É dessa forma "... que um locutor os assume em cada instância do seu discurso.(...). Seu papel consiste em fornecer 0 instrumento de uma conversão, a que se pode chamar a conversão da linguagem em discurso." Estes vão determinar de que forma o sujeito se inscreve no discurso.

Chama-se a atenção para o fato de que a compreensão dos dêiticos é sempre dependente da situação na qual se encontram os interlocutores, pois tanto falantes/leitores como ouvintes/escritores, têm que ser capazes de interpretar qual a situação de comunicação concreta para que sejam capazes de compreender a qual referente o pronome está remetendo.

Para Fowler e Kress (1979), existem diferentes tipos de pronome' nós':

$>$ Existe o 'nós includente', que ocorre quando as pessoas envolvidas são de fato conhecidas ou demonstram solidariedade. Nesse caso há “correlação de subjetividade” Não há a preponderância do 'eu' sobre o 'tu'.

Há também o que os autores chamam de 'nós corporativo', e consideram uma extensão do anterior. É o 'nós', no qual não é possível identificar quem são os indivíduos que o compõem. Como é comumente feito em publicidade, no caso de empresas que anunciam como: 'nós fazemos'. É um nós que não deixa claro quem está incluído nele. A 
fábrica, os operários, os engenheiros, os acionistas, todos com a mesma importância? Esse 'nós' é, na verdade, 'alienante' como afirmam os autores, pois se pretende manipulador dos que embora contidos nele, não têm voz, ou pelo menos, não com a mesma intensidade.

> Existe o 'nós' que é aparentemente solidário, mas na realidade, os interlocutores encontram-se em interações assimétricas e o seu uso se transforma em um pedido ou ordem e indica superioridade por parte de um dos incluídos. Um exemplo é o que ocorre entre patroa e empregada doméstica: "Hoje, 'nós' vamos fazer faxina".

> Existe também um 'nós excludente', no qual o 'nós' entra em oposição aos que não fazem parte do grupo mencionado e, portanto, não traz consigo as mesmas características que unem o grupo enquanto tal, por exemplo: 'nós, ocidentais, ...' em oposição aos que não são ocidentais.

Chega-se à conclusão de que a não ser que as pessoas envolvidas sejam todas conhecidas e que saibamos quais são as relações de poder existentes entre elas, e qual é a intenção do uso do 'nós', ele é potencialmente perigoso, pois extremamente viável de ser utilizado em situações de manipulação.

Outro tipo de modalização muito comum em publicidade é a própria forma como os enunciados ocorrem. Eles são feitos como afirmações absolutas, levando a crer que não há possibilidade de dúvidas a respeito das informações sobre os produtos/serviços apresentados. Isso conduz à certeza sobre o conhecimento do que é representado. Seria uma forma de modalização em relação às crenças que se tem sobre o conhecimento das coisas. Demonstra a atitude de segurança do enunciador em relação aos significados que constrói, pois parece apoiar-se em algo que já estivesse acordado entre os interlocutores e estabelecido por todos como certo (PERELMAN; OLBRECHTS-TYTECA, 2002).

\section{$>$ Índice de avaliação lexical;}

Quanto mais competente um texto, mais provavelmente será recheado de palavras escolhidas cuidadosamente. Palavras que terão seu potencial aumentado pelo jogo retórico e de argumentação imposta. 


\section{- Relexicalização / Rewording}

Relexicalização / Rewording é a criação (FAIRCLOUGH, 1995, 2001) de novos termos para especificar determinadas áreas de atividade, as quais, muitas vezes, já possuíam um termo anterior para defini-las. Isso é feito intencionalmente para fornecer uma nova perspectiva para os falantes. Geralmente isso ocorre em áreas especializadas que estão sendo colonizadas por práticas que anteriormente não interferiam em suas atividades.

$\mathrm{Na}$ maioria das vezes, discursos da área da economia ou da publicidade interferem em áreas que antes não faziam parte da produção de mercadorias ou serviços, como educação, saúde, família. Fairclough (1995, 1999, 2001), Harvey (2004) chamam essa prática de comodificação da linguagem, já discutida no primeiro capítulo. Atualmente é fácil levantar exemplos dessa prática. Basta prestar atenção nos autofalantes dos supermercados ou lojas de departamentos, quando estes identificam funcionários como 'colaboradores', 'associados' etc. Não mais como 'funcionários, empregados etc.'.

É comum a ocorrência de prospectos e documentos de escolas que citam 'serviços educacionais' oferecidos por 'profissionais da educação' a 'consumidores' desses serviços. Não se fala mais de alunos, nem de escolas, nem de professores.

As mudanças não são gratuitas. Elas determinam uma nova forma de encarar velhos problemas, ainda não resolvidos. Ao se referir a empregados através do termo 'associados', definitivamente contribui-se para um mascaramento das relações de trabalho, que estão muito longe de ter a igualdade de direitos sugerida pelo termo 'associado'. O funcionário que passa a ser chamado de 'associado' é obrigado a mascarar sua verdadeira relação de trabalho, muitas vezes sem perceber.

Entre esse processo de relexicalização e as 'palavras de plástico' - que serão vistas logo abaixo - estão os neologismos. Estes são itens lexicais novos no sistema da língua. É um recurso muito profícuo e permite que a língua tenha essa plasticidade necessária para adequar-se a novos acontecimentos, fatos, criação 
de novos objetos e relações. Muitas vezes forçam o usuário a 'deduzir' o novo conceito que ele especifica, dentro de novas relações entre as práticas sociais.

Esse recurso é muito usado em publicidade, pois esta necessita instaurar novos significados e novas relações de sentidos de acordo com o lançamento de novos produtos ou de sua estabilização no mercado em relação com outros itens semelhantes a eles. O neologismo pode servir, de acordo com Fowler e Kress (1979, p. 211), a uma 'reorientação de sentidos para palavras já existentes' ou um termo criado para um novo item inventado por alguém.

\section{- $\quad$ Plastikwörter / Palavras de plástico}

Outro fenômeno que merece atenção é o que Pörksen (1997) denomina de 'palavras de plástico'. O termo foi criado a partir da característica que o plástico tem de assumir as formas mais variadas, independentemente de seu conteúdo. São palavras e expressões que podem ser tomadas da linguagem cotidiana ou neologismos, os quais, no momento em que entram na linguagem dos especialistas, ganham em prestígio, seriedade, e adquirem autoridade. Em seguida, essas palavras são devolvidas à linguagem cotidiana, já não mais com suas significações anteriores, já que ganharam um prestígio que lhes empresta, muitas vezes, ares de verdades inquestionáveis. É a colonização da linguagem de determinados domínios por outros. Neste caso, a colonização da linguagem da vida cotidiana pela ciência ou pela aparência de 'cientificidade' que essas palavras demonstram ter.

Pörksen analisa termos como 'desenvolvimento', 'comunicação', 'progresso', 'saúde', 'sexualidade' etc. Uma das conclusões a que chega é que os sentidos desses termos se tornaram tão elásticos que "perdem seu poder de definição" (ibidem, p. 23) e, conseqüentemente, se tornam pobres de conteúdo.

Outras características interessantes dessas palavras são: sua capacidade de ser universal e de apagar tanto as diferenças históricas e locais quanto a capacidade humana de interferir em seu âmbito de significação e atuação. A expressão 'desenvolvimento sustentável', no anúncio 2 da BASF brasileira, serve como ilustração para isso. Esse termo passa a ser usado pela linguagem do 'novo 
capitalismo' (FAIRCLOGH, 2003) com o sentido de panacéia para diferentes regiões do globo. O uso dessa expressão parece resolver problemas os mais variados, como endividamento, poluição, exaustão dos recursos naturais, pobreza populacional, dependência financeira da comunidade aí tratada etc. Não se define quem serão os agentes e os beneficiados pelo tal 'desenvolvimento sustentável'. Isso será mais bem discutido na análise.

'Novo capitalismo' é usado, aqui, no mesmo sentido definido por Fairclough (ibidem): "...a mais recente de séries históricas de re-estruturações radicais por meio das quais o capitalismo tem mantido sua continuidade básica"13.

Ao mesmo tempo, a freqüência com que essas palavras de plástico são usadas acarreta o 'silenciamento' de outros termos. Termos estes que talvez fossem mais adequados para explicar situações, fatos, fenômenos, coisas, mas que perderam em prestígio ou passaram a ser considerados sinais de não atualização profissional do indivíduo, deixando de ser usados e até mesmo estigmatizando quem os usa ou quem é por eles definidos.

Um exemplo fornecido por Pörksen em relação à publicidade, (que é o tema deste trabalho) é a palavra de plástico 'informação', que é um dos argumentos usados pelos profissionais da publicidade para justificar sua importância (dessa última) em nosso sistema econômico:

A publicidade percebeu: ela se traveste como 'informação'. Grandes companhias que lidam com aparatos de informação e têm lucros de até 50 bilhões de dólares por ano, transferem o grande fluxo de sua propaganda de país para país e moldam discursivamente seus habitantes, depois que estes já se tornaram gerações coca-Cola, agora também em 'gerações informadas' (ibidem, 1997, p. 50), ${ }^{14}$

O autor, além de discordar ironicamente do uso do termo 'informação' para qualificar a atividade da publicidade, mostra como se esvazia, intencionalmente, a capacidade de definição do vocábulo por conta de seu uso ampliado. Chama

\footnotetext{
${ }^{13}$ "I shall use the term new capitalism, meaning the most recent of a historical series of radical restructurings through which capitalism has maintained its fundamental continuity".

14“"Die Werbung hat es eingesehen: sie verkleidet sich als 'Information'. Konzerne, die Informationsgeräte vertreiben und Umsätze bis zu 50Mrd. Dollar im Jahr haben, lassen den Platzregen ihrer Propaganda von Land zu Land wandern und formulieren ihre Bewohner, nachdem schon Coca-Cola-Generationen aus innen geworden sind, nun auch um in informierte Generationen".
} 
também a atenção para o fato de que por intermédio desse tipo de 'informação' que envolve uma quantia tão imensa de capital, seus criadores sejam capazes de 'inculcar'-formas de ação nos habitantes das comunidades nas quais se instalam e atuam.

E aí, volta-se ao que foi afirmado no início deste trabalho: encarar publicidade como veiculação de simples informação a respeito de um produto ou serviço é compactuar com a forma de dominância exercida por qualquer discurso capaz de mascarar suas verdadeiras funções.

\section{- Expressões fraseológicas}

Fraseologia é o campo da lingüística que estuda grupos de pelo menos duas palavras que se unem de maneira mais ou menos fixa e cujo sentido é entendido pelo conjunto de seus componentes, sem necessariamente ter que compreender cada um de seus termos separadamente. Essa junção fixa de palavras pode chegar a formar frases. Fleischer (1997) levanta algumas características que esses grupos de palavras devem preencher para serem inseridos nessa nomenclatura:

$>$ enquanto grupo de palavras ou frases pode ser equivalente a uma única palavra e dessa forma assumir, como essa palavra a que equivale, uma função sintática na frase. “... já que se trata de grupos de palavras ou frases, os critérios de classificação utilizados para as palavras não são completamente transferíveis aos fraseologismos" (ibidem, 110) ${ }^{15}$. Ex.: 'curto e grosso'. Essa expressão não significa 'curto' e 'grosso' mas sim rude, grosseiro.

> a expressão fraseológica exige que seus componentes demonstrem estabilidade ou de alguns ou de todos os seus componentes lexicais. Ex.: como no exemplo acima, não se diz 'grosso e curto'.

$>$ pode ocorrer, no processo de transformação fraseológica, a perda do sentido original de todos os seus componentes. Nesse caso, a

15 „...und da es sich um Wortgruppe oder Sätze handelt, sind die für Wörter anwendbaren Klassifikationskriterien nicht voll auf die Phraseologismen übertragbar“. 
expressão fraseológica será idiomática. Pode ocorrer também a perda do sentido de alguns de seus componentes, o que a torna parcialmente idiomática. Ou podem ser mantidos os sentidos originais de todos os seus componentes, que não serão considerados idiomáticos. Ex.: 'pagar o pato' é uma expressão idiomática, pois não significa pagar por essa ave, mas sofrer conseqüências.

$>$ a sua reprodução é dependente do contexto.

Burger (1998) acrescenta também que os fraseologismos são armazenados e compreendidos como uma unidade mental. Isso vem a ser de extrema praticidade em publicidade, que, geralmente, utiliza pouco espaço físico e pouco tempo. Dessa forma, busca-se evocar os scripts desejados com mais facilidade.

Para Gülich (1997), fraseologia é um tipo de conceito mais abrangente, que inclui não apenas formas fixas da língua, que se materializam nas formas discutidas acima, mas também nas formas de rotinas lingüísticas como, por exemplo, nas expressões: "bom dia, tudo bem, até logo, boa noite etc.", que têm uma utilidade completamente pragmática. Encontram-se, também, sob essa noção mais abrangente as formas fixas de construir determinados textos que a autora chama de formuláicos.

Alguns textos, por ela pesquisados, funcionam como um modelo fixo no qual apenas algumas lacunas são preenchidas com os novos dados, mas em que a estrutura geral do texto se mantém, inclusive com o campo semântico quase imutável, como nos exemplos citados por ela: anúncios fúnebres e convites de casamentos.

De acordo com sua opinião, alguns critérios devem ser seguidos para que esses textos se incluam como textos formuláicos:

1- a possibilidade de prever sua ocorrência no decorrer da comunicação;

2- a obrigatoriedade de sua ocorrência;

3- a sua dependência situacional para possibilitar a compreensão;

4- a sua dependência cultural. 
Em ambas as definições, encontram-se pontos em comum: trata-se de convenções tácitas na forma de encadeamentos mais ou menos fixos dos termos, assim como da dependência situacional.

A ordem de combinabilidade entre os termos da expressão fraseológica pode ocorrer nos níveis sintático, semântico e pragmático (TAGNIN, 1989).

No nível sintático, existem encadeamentos provocados por regência dos termos, por combinações já convencionalizadas pelo uso, entre outras possibilidades.

No nível semântico, muitas vezes entram os fatores apontados por Blikstein (1985) e Lakoff; Johnson (2002), nos quais a cultura determina quais tipos de combinações vão atingir quais valores. Por exemplo, em nossa cultura ocidental, 'para cima' tem valor positivo. Isso é mostrado nos exemplos levantados por Tagnin (1989): 'Ele é alto astral.'; 'Cabeça erguida.' E também: 'Sentir-se leve.”; 'Feito uma pluma.' Naturalmente, surgem seus opostos: 'Estar para baixo.'; 'Estar sentindo um peso.'; 'Estar na fossa.'

No nível pragmático, podemos acionar Gülich (1997), quando esta cita as formas exigidas em rotinas lingüísticas, pois de acordo com determinadas situações aciona-se também, não apenas determinado comportamento como também determinadas ações lingüísticas.

Podem ser citadas como exemplos de fraseologismos algumas construções estáveis, porém não idiomáticas, encontradas nas publicidades da BASF brasileira como: 'substantivo + atributo', em alemão, 'Atribut + Substantiv', nas quais o adjetivo transforma-se em um "epíteto fixo" tal como: "desenvolvimento sustentável', 'comunidade carente', 'optmierte Prozesse'. A estabilidade dos termos, dá a eles um caráter de terminologia científica, que acaba por transformálos em clichês econômicos ou sociológicos.

Essa estabilidade de termos científicos, políticos e ideológicos de determinados grupos de palavras ou frases, faz com que se tornem espécies de palavras de ordem, dentro de determinados paradigmas, com significados mais ou menos esvaziados, mas que trazem consigo grandes cargas de valoração positiva ou negativa. 
Os provérbios também podem ser explicados por intermédio da definição de fraseologismo fornecida acima. Assim como o fraseologismo, os provérbios também são armazenados mentalmente como unidades semântico-pragmáticas e trazem consigo grande quantidade de informação. Porém têm outras características adicionais.

Eles agem como se fossem ensinamentos condensados em pequenas porções. São frases 'fossilizadas' que representam materialização de conhecimentos e experiências comunitárias, tidas como parte do senso comum, já assimiladas há longo tempo. Apresentam-se como frases, muitas vezes, sem elementos que definam características temporais ou locais, de forma a deixar uma margem de ação bem vasta, de forma a serem acionadas de acordo com a situação, da qual são dependentes para poderem ser usadas e compreendidas.

Os provérbios vêm condensados em pequenas fórmulas, obtidas por meio da codificação em enunciados de grande concisão, que podem se articular de diversas formas. Entre elas, por parataxe, por construções rítmicas ou rimadas, por repetições, por paralelismos, por antítese etc.

Segundo Glenk (2000, p. 23). "Os provérbios acionam, de acordo com o desejo do falante, um determinado efeito na mente do ouvinte." 16

Não se pretende discutir neste trabalho as inúmeras possibilidades de formação dos fraseologismos. Queremos, porém, deixar claro que os fraseologismos exercem um grande poder de atuação em relação à ativação de frames e scripts. Sua ocorrência em anúncios publicitários é profícua, talvez por possibilitarem o acionamento imediato dos tais frames e scripts entre os leitores que são familiarizados com a vinculação entre os termos e, destes, com determinadas situações. Assim, economiza-se tempo, tão importante para a publicidade. Os fraseologismos são usados regularmente em determinadas situações, como já foi dito e, portanto, a partir deles é possível identificar ações e idéias carregadas de valores avaliativos e afetivos.

\footnotetext{
16 "Sprichwörter rufen, wie vom Sprecher geplant, eine bestimmte Wirkung im Bewusstsein des Hörers hervor"
} 
Ìndices de polifonia - pressuposto, subentendido e intertextualidade

Ducrot (1987) diferencia as figuras do locutor e do enunciador. Para ele, o 'locutor' é o responsável pela fala, o falante real. Reconhece que existe uma produção concreta do falante, encarado como o falante empírico. Já o 'enunciador' é o personagem, é o ser que fala de um determinado lugar de enunciação, é onde se atualizam os diversos pontos de vistas que se imiscuem na fala do locutor.

Segundo este autor, essa emergência de diferentes pontos de vista dentro do enunciado podem ser rastreados lingüisticamente. Dentro dessa produção empírica do falante, inscrevem-se 'vozes' de outros falantes, que podem ser detectadas através da própria organização lingüística. Para ele, a retomada de um enunciado que remete a outro é chamada de polifonia. Tal polifonia ocorre através do processo de argumentação que é inscrito em qualquer língua. Ela faz parte da própria língua e pode ser resgatada.

Koch (1996, p. 143) afirma que: "A condição para que haja polifonia é, pois, que o locutor $L$ seja diferente do enunciador $L$ ': o locutor $L$ faz com que outro personagem [L'] diga algo no interior do seu próprio discurso". (negrito da autora). O locutor $L$ é a pessoa empírica, que ao tomar para si a fala, se atualiza em L'.

A polifonia pode ocorrer na forma de pressuposto, que pode ser identificado como um dos índices da polifonia. É um índice lingüístico-pragmático da heterogeneidade da linguagem ao inserir no texto a voz desse outro, aquela 'voz' que fica submersa à superfície textual, mas que pode ser resgatada porque é parte da construção global do texto.

Uma das formas de se resgatar o que foi dado como pressuposto é através do exame da argumentação. Esta é entendida como a organização de vários elementos que funcionam como pistas e que orientam instruções para a forma de compreensão do enunciado. É estruturada, entre outros mecanismos, por operadores argumentativos, pelo resgate de termos referenciais por intermédio do uso de pronomes, pela escolha de determinados tempos verbais.

Ducrot (1996) ainda diferencia o pressuposto do subentendido. Enquanto o pressuposto está inscrito na língua, e, portanto, faz parte da estruturação 
lingüística da argumentação, o subentendido fica por conta de quem ouve/lê. Faz parte dos contextos conversacionais, de conhecimento de mundo e não diretamente da língua. No processo de compreensão de informações pressupostas ou subentendidas devem ser acionados os conhecimentos lingüísticos e de mundo, partilhados pelos interagentes. Essas informações devem ser percebidas como conjuntos de proposições, que devem ser conhecidas pelos interlocutores.

Ambos, tanto o pressuposto como o subentendido, são acionados no decorrer da comunicação, por intermédio dos contextos nos quais ocorrem. Por meio de determinadas expressões, operadores argumentativos ou construções lingüísticas, ocorre a ativação de determinadas pressuposições ou subentendidos. Abaixo, apresentamos um exemplo que surgiu em nossa análise e que serve para demonstrar algumas maneiras como isso pode ocorrer:

O uso de descrições definidas pressupõe um certo grau de certeza sobre a existência do ser a que ela se refere (Polenz, 1985). No anúncio 1 da BASF, encontramos: 'Die Ergebnisse unseres Beitrags können... / Os resultados de nossa contribuição podem...'

A proposição é: 'Os resultados de nossa contribuição podem ser vistos'. Parafraseando: A nossa contribuição produz resultados. / Contribuímos com resultados'. (que podem ser vistos). O posto é a informação veiculada.

O pressuposto é o que pode ser inferido pela sua enunciação. Que a BASF, realmente, contribui e que já tem resultados 'reais' que podem ser vistos, que já são conhecidos e comprovados por todos e por isso a BASF pode ser afirmativa. O pressuposto, nesse caso, poderia ser substituído pelos itens que aparecem na parte inferior do anúncio: Chemikalien, Kunststoffe, Veredlungsprodukte etc. A idéia é generalizar as qualidades positivas - a contribuição e os resultados - em todas as atividades produtivas da BASF.

Como um bom exemplo de subentendido, podemos citar o enunciado do anúncio da Pfizer: 'In jeder Beziehung. / Em qualquer relação'. Quando esse enunciado é vinculado à sentença anterior, fica ambíguo e temos que acionar 
outras esferas do conhecimento de mundo para pensarmos nas mais diversas possibilidades. O porquê da ambigüidade será analisado posteriormente.

Em publicidade, tanto o uso do pressuposto como do subentendido são recursos retóricos fundamentais, pois tanto permitem colocar como já sendo do conhecimento dos leitores algo que, muitas vezes, está justamente sendo apresentado, como permitem a criação de vários outros sentidos, estes no nível de desejos, necessários para conseguir a adesão do leitor/ouvinte.

A intertextualidade também é estudada como um índice de polifonia. Segundo Fairclough $(1995,2001)$ e Fix (2003), intertextualidade é um termo criado por Kristeva, baseada em Bakhtin. A princípio se restringia à Literatura, mas passou para a Lingüística e se refere ao processo dialógico entre os textos que vão surgindo sempre com referência aos textos já ditos/escritos anteriormente e que remetem a textos que serão ditos/escritos no futuro.

Afinal, como discute Bakhtin (1995, 2000), nenhum texto surge do nada, sem fazer referência a outro, sem que esteja dependente de um contexto anterior. Todo texto é apenas mais um elemento nessa cadeia discursiva, nesse universo de textos. A essa remissão a textos anteriores em textos atualizados dá-se o nome de intertextualidade.

Para Fix (2003), o próprio fato de que existem tipos de textos, agrupados por semelhanças quanto às formas de construção e quanto ao uso, já indica uma intertextualidade, pois isso implica recorrência dessas mesmas formas, de acordo com o conhecimento de mundo do falante.

A intertextualidade chama conceitos como a heterogeneidade dos textos, que são todas essas permanências, veladas ou não, de outros textos que continuam a existir dentro dos novos, quando de sua re-elaboração. Pode, até mesmo, ser pelo silêncio que estes novos textos fazem em relação a velhos 'ditos'.

A intertextualidade pode ser 'manifesta' quando a recorrência a outros discursos vem marcada por aspas ou outros recursos de clareza de origem, ou mesmo mista: "... em que textos ou tipos de discursos estão fundidos de forma mais complexa e menos facilmente separável" (FAIRCLOUGH, 2002, p. 152). 
A intertextualidade pode ser 'constitutiva' ou também ser chamada de interdiscursividade. Nesse caso existe, além da recorrência marcada por intermédio de alguns recursos elencados acima, a interdependência de formações discursivas que se configuram em um texto.

Formação discursiva trata-se de conjuntos de enunciados que trazem consigo as mesmas "regras de formação" (FOUCAULT, 1991). Regras de formação, nesse contexto, não dizem respeito apenas a regras sintáticogramaticais, mas sim a todo um contexto sócio-histórico que condiciona, de acordo com a posição do indivíduo, imerso nessas relações, o que pode ser dito, como isso poderá ou deverá ser verbalizado e em que relações isso poderá ocorrer.

Estas formações discursivas, por sua vez, são determinadas pelas várias formações ideológicas que as originam. Estas últimas são visões de mundos, isto é: “... um conjunto de representações, de idéias que revelam a compreensão que dada classe social tem do mundo..." (FIORIN, 1990, p. 32). Tanto as formações ideológicas como as discursivas não estão no nível do consciente, já que as origens de suas criações teriam sido apagadas. A cada formação ideológica correspondem muitas formações discursivas e estas últimas podem pertencer a diferentes formações ideológicas, tampouco pode ser dito que essas formações ideológicas são estanques entre si.

Deve-se lembrar que em sociedades tão complexas como as nossas, os indivíduos se relacionam socialmente em diversos grupos, como, por exemplo, na esfera familiar, na escola, profissionalmente, afetivamente, o que acarreta inúmeras formações ideológicas e discursivas, que estão sempre se entrelaçando umas às outras, permitindo dessa forma a interdiscursividade.

E como nesse 'mercado lingüístico' (BOURDIEU, 1996) nem todas as formações discursivas têm o mesmo poder de se impor perante outras, isso determinaria o porquê de determinadas formas serem mais aceitas do que outras. O que não quer dizer que as formações discursivas menos aceitas ou até mesmo as que sejam desqualificadas ou caladas, deixem de existir. Elas têm função até pelo que silenciam. Isso fica muito claro, nos anúncios da Pfizer. 
Em suma, são as formações discursivas e ideológicas que vão definir o que 'pode ou não ser dito e onde', são elas que vinculam o indivíduo ao tempo/espaço/sociedade, tornando-o um sujeito historicamente determinado e compreensível (FOUCAULT, 1991).

Ao utilizar essas categorias, buscam-se quais diferentes textos, quais diferentes discursos estão delineados na elaboração dos textos publicitários analisados e quais as conseqüências para a sua interpretação.

Estas pistas lingüísticas determinam o histórico e o ideológico das relações que cada interlocutor estabelece com o mundo em que atua. Essa atuação, como já foi visto no capítulo 1, não acontece sem confrontos. É nos diálogos resultantes desses encontros e confrontos que o sujeito se constitui, sempre imerso em um contexto histórico e social.

\subsubsection{Categorias da linguagem visual}

O processo de modalização não se restringe à comunicação verbal, é um processo que também ocorre em comunicação visual. A imagem, em se tratando da publicidade, é criada de forma a representar os objetos ou serviços produzidos pelas indústrias, usados por personagens em determinados lugares e situações, sempre com o intuito de atingir grupos específicos. Toda composição visual funciona, de uma certa forma, como "um signo motivado nos quais valores, crenças, interesses desse grupo encontra uma expressão" (KRESS; VAN LEEUWEN, 2001, p. 163).

Essa composição é reconhecida como um signo, conscientemente ou não, porque o processo de sua elaboração não ocorre repentinamente. Ao longo da história da humanidade, foram sendo criados símbolos que preservaram suas experiências, vivências, acontecimentos etc., poupando o tempo do ser humano por intermédio do reconhecimento dos mesmos. 
Por exemplo, o surgimento da escrita é um dos resultados desse processo, assim como a composição da imagem, seja num quadro de qualquer época ou numa publicidade. Dentro desse contexto, de acordo com Dondis:

Qualquer acontecimento visual é uma forma com conteúdo, mas o conteúdo é extremamente influenciado pela importância das partes constitutivas, como a cor, o tom, a textura, a dimensão, a proporção e suas relações compositivas com o significado (DONDIS, 2003, p.22).

As modalizações serão feitas por intermédio desses elementos compositivos da imagem. Os autores acima citados discutem diferentes componentes. Os que mais nos interessam para este trabalho são esboçados abaixo:

- lugar de posicionamento dos objetos representados na composição do anúncio, como por exemplo: o elemento que se encontra mais centralizado recebe uma modalização de importância maior do que os que estão nas margens; o que está em cima é mais ligado ao céu, e, portanto, ao imaginário, ao divino e o que está em baixo é mais real, mais terra. Também entra aí uma valorização hierárquica, isto é, o que está mais acima pode ser considerado mais importante, mais poderoso, mais desejável ou mesmo até mais ameaçador, dependendo da composição.

- ângulo - existe, também, a possibilidade de atrair mais ou menos atenção para um objeto representado. Por exemplo: o que está colocado em um ângulo mais próximo do espectador também ganha em importância em relação ao que está mais longe. Nesse caso, o que é apresentado como fundo tem menos realce do que a figura. Fala-se, nessa relação, em 'figura' - o que está colocado de forma a ficar no foco da atenção do indivíduo - e 'fundo' - o que, intencionalmente, não está colocado para captar a atenção do espectador.

- diferentes tons, que é a presença, gradação ou ausência de luz; sua parte complementar são os elementos cromáticos. Estes, segundo vários autores, o componente visual mais expressivo e emocional. A opção por um determinado conjunto desses elementos indica diferentes abordagens, por exemplo: tons 
pastéis ou figuras difusas significam menos certezas, mais componentes etéreos, do que a realidade, que se procura representar por figuras bem definidas e cores firmes. Isso é equivalente às modalizações lingüísticas, só que com efeitos mais rápidos e menos conscientes no interlocutor.

- a cor é o elemento que mais rápido atua sobre o olho humano, e por ser uma experiência comum a todos, transforma-se de uma experiência individual em coletiva, e vem carregada de informação que é facilmente controlável (DONDIS, 2003). Por isso a opção pelo vermelho ao se desejar direcionar a leitura do interlocutor para paixão, sexualidade ou raiva, ou para uma série de outros significados como perigo, calor etc.

Em cada uma das cores escolhidas pelos produtores dos anúncios podem ser lidos muitos sentidos associativos e também simbólicos. "Assim, a cor oferece um vocabulário enorme e de grande utilidade para o alfabetismo visual" (ibidem, $p$ 64). A cor contém três dimensões: o matiz, que é a cor propriamente dita; a saturação, que é a pureza da cor, cuja ausência leva ao cinza; e o brilho/tom, que são as gradações do claro ao escuro. O jogo com essas três dimensões da cor possibilita a criação de modalizações de acordo com os sentidos que se deseja criar.

- divisões - elementos que se encontram divididos por linhas definidas ou elementos que tenham essa função, criam uma idéia de separação e indicam falta de conjunto, de não-pertencença ao passo que elementos que se apresentam como fazendo parte de um conjunto constroem a idéia de pertencença, de ligação.

- formas básicas - existe em tudo o que vemos uma estrutura composicional abstrata, e isso possibilita a transformação em formas básicas de qualquer coisa que se apresente diante dos olhos. Essas formas básicas são o "... círculo, o quadrado e o triângulo..." a partir dessas formas, surgem quantas "... variações, combinações, permutações, de planos e dimensões; ..." (DONDIS, 2003, p.23) forem necessárias para a construção de sentidos desejáveis.

Essas formas básicas vêm carregadas de significados que se unem a eles por motivos associativos ou por acordos. Esses significados também podem surgir “... por nossas próprias percepções psicológicas e fisiológicas. Ao quadrado se 
associam enfado, honestidade, retidão e esmero; ao triângulo, ação, conflito, tensão; ao círculo, infinitude, calidez, proteção" (ibidem, p. 58).

Os mecanismos citados nos itens acima ocorrem em gradações e funcionam de maneira conjunta na composição da imagem. Quando muito acentuados, tanto para mais como para menos, indicam maior modalização.

Como pode ser visto, pelo que foi apresentado acima, a comunicação visual também é codificada. Se a sintaxe dos códigos visuais não é tão estudada quanto a da língua, é apenas porque nossa sociedade dá mais importância à sintaxe lingüística em detrimento da visual. Esta última só nos parece simples e transparente porque temos o conhecimento necessário para interpretá-la, mesmo que inconscientemente. Nesse contexto, mais do que nunca, fica claro que o mito da transparência é apenas um mito.

O ser humano faz uso de diferentes modos de representação e cada um deles adiciona valores aos sentidos que se pretende construir e estes modos de representação não são mantidos “... discretamente, separadamente, como domínios autônomos no cérebro, ou como fontes de comunicação autônoma em uma cultura, (...) ao invés disso se embaraçam e interagem o tempo todo" (KRESS; VAN LEEUWEN, 2001, p. 39) ${ }^{17}$. Por causa dessa interferência que ocorre entre os modos de representação responsável pela construção dos sentidos dentro da publicidade, essas categorias serão utilizadas por ocasião da análise do corpus.

\footnotetext{
17 "The different modes of representation are not held discretely, separately, as autonomous domains in the brain, (...) rather, they intermesh and interact at all times".
} 


\section{RETÓRICA E SEU USO NA PUBLICIDADE}
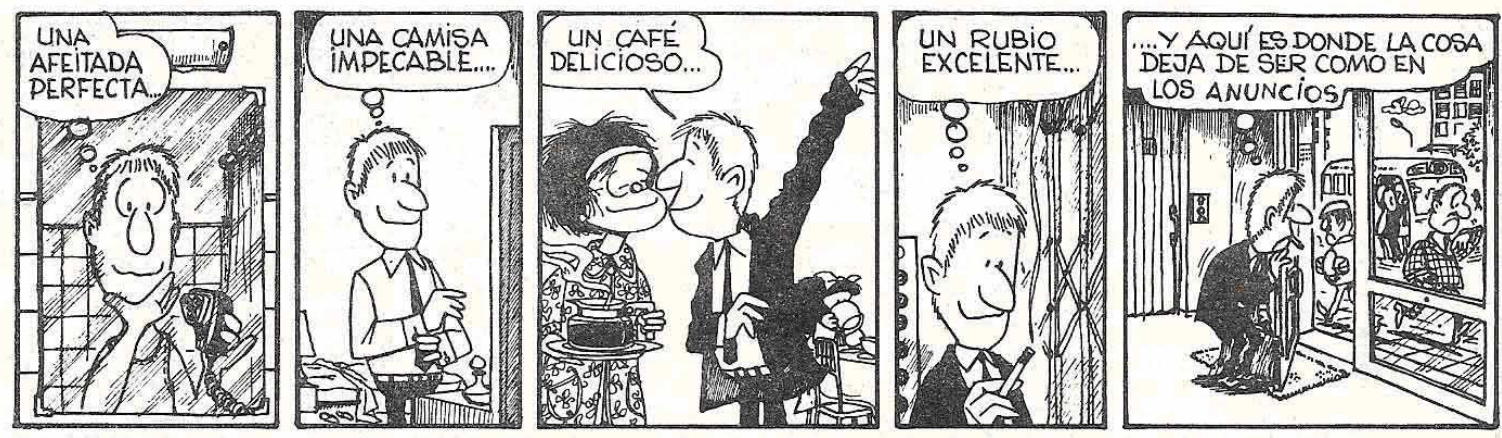

(LAVADO/QUINO, 1979)

A publicidade funciona como uma junção feliz de várias linguagens. Além dos elementos lingüísticos, escritos ou falados, de acordo com o veículo usado para transmiti-la, insere a música, a fotografia, a imagem em movimento, o desenho, as cores, a tonalização e outras linguagens, tudo isso dentro de uma forma de organização própria, com objetivos bem definidos. A publicidade continua fazendo uso, de forma atualizada, de regras estipuladas pelos sofistas e esquematizadas mais tarde por Aristóteles. Naturalmente, esse uso não ocorre com a mesma rigidez imposta por uma sociedade mais estática como a de dois mil anos atrás.

Boa parte da forma como os anúncios são apresentados atualmente é determinada por condições que não existiam anteriormente, tais como: o avanço das possibilidades tecnológicas; a concorrência imposta pela economia de mercado na qual está imerso o chamado mundo globalizado; a inovação contínua da produção industrial; a existência de um mundo multifacetado e mais dinâmico que permite ao indivíduo trafegar em muitos espaços, mobilidade que antes the era negada, além de outros fatores.

O próximo item a ser discutido é a retórica na história, pois consideramos que nada se faz se não soubermos qual o desenvolvimento histórico do objeto em estudo, mesmo porque os anúncios de hoje continuam aplicando, de forma atualizada, boa parte das regras de argumentação identificadas e ensinadas por Aristóteles e pelos sofistas. 


\subsection{Retórica e sofistas}

Ao longo do percurso de investigação sobre a relação da língua com a realidade e sobre a forma como o ser humano se insere nessa relação, surgiram as primeiras teorias. Para esses precursores que tentaram desvendar essa relação, a língua teria um poder cósmico criador, a palavra teria o poder de revelar o ainda não percebido.

No percurso da investigação lingüística surgem os Sofistas, para os quais já estava claro o poder da língua em criar verdades, agora não mais com o poder cósmico criador dos antigos. Para eles a língua servia para convencer outrem de que algo era ou 'deveria' ser da maneira como eles construíam a sua fala. A verdade ou não dos fatos não importava, o objetivo era o convencimento. $O$ objetivo era criar técnicas de elaboração de discursos belos e ao mesmo tempo eficientes, isto é, convincentes. O importante era tornar crível o mais fraco dos argumentos, ou o contrário.

Em função de melhorar a retórica e desenvolver a argumentação, a fim de convencer seu ouvinte, Dinneen (1996) afirma que eles eram empiricistas, pois estudavam a linguagem com o propósito de descobrir qual seria a melhor forma para seus discursos. Fizeram da linguagem seu meio de trabalho, ensinando a seus alunos como influenciar e seduzir por intermédio da linguagem, com o claro objetivo de ganhar discussões ou vencer as disputas travadas em tribunais.

Para esses estudiosos da possibilidade de influenciar pessoas, o que interessava, não era o estudo da língua em si, mas o seu estudo como um meio para se alcançar o objetivo de conduzir pessoas a uma determinada forma de pensar. Disso resultou, à época, um estudo cuidadoso de figuras de linguagem, de argumentos que pudessem ser agrupados de acordo com os temas para os quais pudessem servir de fundamentação. Uma ferramenta, uma técnica para exercer essa capacidade: a de influenciar pessoas.

Peninou (1974, p. 105) chama a atenção para a discussão entre Sócrates e os Sofistas. Enquanto, para o primeiro, o estudo da Retórica deveria servir para instruir o ser humano, para os segundos, no dizer de Sócrates referindo-se a 
Górgias, esta serviria apenas para convencer: "operária, (...) da persuasão que faz acreditar, não da que faz saber".

Por seu lado, Górgias via a Retórica como o ensinamento a serviço da persuasão, já que este não acreditava na possibilidade do conhecimento do real. Defendia a posição de que nada existe, e se existisse seria impossível de ser conhecido, e se fosse possível de ser conhecido, seria impossível de ser comunicado (NEUMANN, 2001). Por cair nesse total relativismo, pode-se entender a necessidade de se colocar nas palavras a possibilidade da construção da realidade desejada, encontrando na Retórica o caminho para influenciar a opinião dos ouvintes e levar à tomada de decisões. Dessa forma entende-se a citação de Górgias em Nef:

Pois o meio que temos de revelar o ser é o discurso, e o discurso não é nem as substâncias nem os seres; não são pois os seres que nós revelamos àqueles que nos cercam; nós só lhes revelamos um discurso que é diferente das substâncias (GÓRGIAS, apud NEF, 1995, p. 12).

Como podemos ver, já nessa época, foram empreendidos esforços conscientes para a caracterização de fenômenos textuais, com o objetivo pragmático. No centro das indagações que seguem essa linha de busca de conhecimento, sempre esteve a preocupação sobre como alcançar a melhor forma para atingir bons efeitos comunicativos; de que forma o ato de convencer 'o outro' pode ser levado a cabo da melhor maneira, levando em consideração desde a ordenação das idéias, textos, pronúncia, gestos etc.; como a percepção de que, para a produção do texto, é importante a inserção da situação onde esse texto é proferido para ser bem sucedido. E tudo isso por intermédio de meios retóricos especiais.

Heinemann; Viehweger corroboram:

Nesse sentido, a retórica pode ser entendida como um apanhado de conceitos e regras para uma efetiva apresentação pública, como 'ars bene dicendi' (...) que sempre era pensado com a formulação 
requintada e rebuscada de um tema (Heinemann; Viehweger 1991, p. 20). ${ }^{18}$

Durante milênios, o estudo e o exercício da Retórica oscilaria entre dois pólos. De um lado, estavam os que vêem a Retórica como a manipulação da língua com o intuito de seduzir, enganar. Enfim, torná-la agradável aos ouvintes, porém sem conteúdo ou comprometimento com a 'educação para a verdade'.

Do outro lado, os que percebiam as possibilidades que se abriam em virtude dos ensinamentos levados a cabo pelos sofistas. Cultivavam a 'Arte de falar bem', que compreendia um conjunto de regras a serem transmitidas, possibilitando a criação de conhecimentos, com uma força de convencimento previsível. A última parte dessa definição - a previsibilidade - tornou-se alvo de estudos dos que lidam com a linguagem enquanto criadora de sentidos e em sua força de levar indivíduos a ações desejadas. Esse 'previsível' seria justamente o que deveria ser ensinado, ou seja, as regras, as maneiras de se moldar 'qualquer' tipo de fala para atingir um fim: o convencimento do auditório.

No decorrer desse percurso, os Sofistas reconheceram que nenhuma verdade é permanente e duradoura e, aparentemente, nenhum código de valores é eterno, por isso trabalhavam com a palavra. Provavelmente, por esse motivo eram mal-vistos por alguns filósofos atenienses, já que colocavam em risco a crença na imutabilidade da sociedade e talvez possibilitassem um questionamento a respeito da participação de homens 'justos e corretos' na democracia ateniense.

Quando o Sofista Protágoras afirmou ser 'o homem a medida de todas as coisas', ele teve uma feliz intuição das relações que ocorrem na construção do que é real. Com essa constatação, abria espaço para a percepção de que o existente é variável de acordo com o observador, e que a realidade é ditada pela coletividade (GILES, 1993, p. 240).

A lógica aristotélica, por sua vez, buscava 'comprovar verdades objetivas'. Verdades tão caras, até hoje, à crença na objetividade da informação, e que por mais de dois mil anos tem servido a tantas elites dominantes da sociedade

18 "In diesem Sinn kann die Rhetorik als Sammlung von Begriffen und Regeln für ein wirkungsvolles Auftreten in der Öffentlichkeit verstanden werden, als, "ars bene dicendi" (...), die stets auf schmückende und verfeinernde Ausformung eines Themas gedacht war". 
ocidental, levando a essa concepção de ciência determinista, como uma possibilidade de se apossar do real sem intermediários, e levando a crer que houvesse uma lógica acima das relações de poder.

Os sofistas foram os grandes introdutores da percepção de que a medida das coisas não era Deus, nem uma verdade duradoura, inquestionável, mas sim os seres humanos, a buscar a satisfação de suas necessidades, que variam de acordo com o tempo em que ocorrem. Este relativismo assustava e assusta as "verdades estabelecidas" pelo mundo afora. Talvez por isso, eles ficaram esquecidos ou foram detratados no decorrer da história.

Perelman (2002, p. 50) chama a atenção para o fato de que os grandes 'detratores da retórica' foram aqueles "para os quais só havia uma verdade, em todas as matérias". E, logicamente, competia ao filósofo, naquela época, e ao cientista, durante muito tempo, 'imparcialmente', estudar todos os ângulos de um problema, fato, ou situação.

Aristóteles $(1983,31)$ vai estudar a linguagem não como um fim em si, mas como um meio de montar seu sistema lógico que pudesse desmontar os argumentos ilusórios dos sofistas. 'Existe, além disso, o desvio sofístico do argumento, mediante o qual levamos nosso adversário a fazer uma espécie de afirmação contra o qual estamos bem providos de linhas de argumentação".

A linguagem não era um campo de estudo independente, mas deveria ser estudada porque ela era 'a forma' por intermédio da qual se poderia chegar ao que é 'verdadeiro'. Teria de ser estudada como uma técnica que permitia o conhecimento. Uma técnica dividida em vários estágios que pudesse organizar a forma de repassar esse conhecimento. Essa técnica poderia ser aplicável a todos os campos, fosse para desarmar os sofistas, com seus discursos cheios de figuras retóricas e 'armadilhas', fosse para construir modos de inferência sobre a verdade e a lógica ou até mesmo para estudar de que forma a linguagem é capaz de veicular emoção (NEF, 1995). Para esse mesmo autor, há que se vasculhar muito o trabalho do filósofo grego para se encontrar opiniões sobre a linguagem.

Para Aristóteles, Retórica é: “... a faculdade de ver teoricamente o que, em cada caso, pode ser capaz de gerar persuasão, (...) e no concernente a uma dada 
questão, descobrir o que é próprio para persuadir" (ARISTÓTELES, s.d., p. 22). Como foi dito, não há aplicação dessas regras a campos determinados, mas a todos os campos. Ele a considera 'faculdades de fornecer argumentos' porque:

... o verdadeiro e o justo são, por natureza, melhores que seus contrários. Donde se segue que, se as decisões não forem proferidas como convém, o verdadeiro e 0 justo serão necessariamente sacrificados: ... (ibidem, p. 20).

Para este autor, a Retórica seria necessária para poder fundamentar um argumento verdadeiro, portanto não se deveria fazer uso dessa faculdade sem a ética. A justiça é, para ele, imprescindível para decisões a serem tomadas. "Pois não se deve persuadir o que é imoral". (ibidem, p. 20) Ele não condena a retórica como a arte do engano ou o belo sem conteúdo, mas dá a ela parâmetros de boa forma e a transforma num instrumento para viabilizar 'o correto, o justo'.

O domínio de técnicas 'de como organizar bem o discurso' era algo de muita importância entre os cidadãos de Atenas, visto que a democracia ateniense era o espaço de discussão sobre como gerir a cidade e isso era feito através de discussões em praça pública, portanto, era essencial saber fazê-lo, para conseguir convencer pessoas de seus argumentos. Ali, a capacidade de ser eloqüente desempenhava decisivo papel político.

De qualquer forma, tanto Aristóteles quanto os Sofistas, por mais que se opusessem, foram o ponto de partida do movimento moderno que estuda a argumentação. Entre eles, Perelman e Olbrechts-Tyteca (2002) que inauguram a 'Nova Retórica' na Europa. Estes - além de Brown (1971), Spang (1987) e outros - vão investigar as condições de força persuasiva de diferentes tipos de argumentação em diferentes campos, tanto com uso de linguagem informal como formal. Não se está mais preocupado, como Aristóteles, em buscar o justo e o correto. Não há necessidade, na retórica atual, de que haja uma conclusão 'irretorquível' e universal, mas de que forma ocorre a adesão a algo proposto.

O curioso é que embora tenha sido Aristóteles quem elaborou eficientemente essas técnicas de argumentação, ele não tinha direito a usá-las em praça pública. Por não ser ateniense, não tinha direito à voz. 
O próximo item a ser discutido é a retórica na história, pois consideramos que nada se faz se não soubermos qual o desenvolvimento histórico do objeto em estudo, mesmo porque os anúncios de hoje continuam aplicando boa parte das regras de argumentação identificadas e ensinadas por Aristóteles e os sofistas.

\section{2. Retórica na História}

Analisaremos agora, grosso modo, o papel que a Retórica teve ao longo dos séculos.

No decorrer dos últimos três milênios, a Retórica foi se recriando, se adaptando de acordo com a necessidade e os acontecimentos, de acordo com momentos nos quais houvesse maior ou menor espaço de atuação para indivíduos poderem interferir em decisões que lhes diziam respeito (SPANG, 1987).

Teremos, por um lado, uma retórica dialógica que preenche a necessidade de um espaço real de debates para poder existir como forma de atuação social, interferindo em tomadas de decisões, contribuindo para a criação de pactos sociais que levem em consideração bom número de argumentos, sendo, portanto, não-autoritária. Por outro lado, temos uma retórica que funciona mais como um exercício mental, como técnicas mnemônicas que estimulam a memória, que está a serviço de debates pouco representativos para a mudança da sociedade, enfim, uma retórica de momentos autoritários que se convencionou chamar de "Retórica" no sentido pejorativo: um discurso vazio, sem conteúdo.

Segundo Spang (1987, p. 15), desde o início da civilização grega até o século XVIII : “..., dominar a palavra e a língua era tido como uma das mais realçadas capacidades do ser humano como ser racional". ${ }^{19}$ Esse domínio é tido como a 'ars bene dicendi' ou 'sistematização e ensino' da arte do 'bem' falar e o próprio orador, como o expositor, era o demonstrador dessa arte.

\footnotetext{
19 "Wort und Sprache zu beherrschen, galt als eine der hervorstechendsten Fähigkeiten des Menschen als Vernunftwesen.")
} 
Acrescenta-se que, no decorrer da história, o exercício da Retórica pende ora para 'um conteúdo agradável aos ouvidos, porém sem conteúdo', ora para 'uma técnica que é exercida para se construir uma opinião pública, um espaço democrático'. Cada uma das tendências ocorrerá de acordo com o momento em que se encontra a humanidade.

É interessante notar que essa última tendência sempre esteve ligada a períodos de liberdade, a períodos em que, de certa forma, para os indivíduos, o exercício do poder de argumentação foi possível. O que eles têm em comum é que são períodos nos quais os homens encontram espaço para discussões e defesas de opiniões, onde podem expressar suas querelas e desejos políticos.

A possibilidade do exercício da retórica surge, portanto, dentro de um espaço de relativa liberdade. Com sua perda, a retórica passa a ser mais uma matéria escolar, uma técnicas encarada como contribuição para a boa formação de indivíduos que têm acesso a uma educação mais privilegiada, do que propriamente participação política em decisões.

Da mesma forma como aconteceu na Grécia, ocorre também em Roma. Com a queda da República, a Retórica entra novamente em decadência e deixa de exercer a função de organizadora do espaço público democrático e: “... sem um campo real de ação, passa a preocupar-se consigo mesma e degenera num espetáculo pomposo e teatral" (ibidem, p. 22). ${ }^{20}$

$\mathrm{Na}$ Idade Média, a Retórica faz parte de um grupo de conhecimentos chamado 'artes livres', divididas em trivium (Gramática, Retórica e Dialética) e quadrivium (artes matemáticas: Aritmética, Geometria, Música e Astronomia). Tal grupo de conhecimentos deveria ser ensinado e 'apreciado' por homens livres, já que estes deveriam se preocupar com as artes do pensamento, em oposição aos indivíduos que exerciam as 'artes manuais', no caso, os servos e artesãos.

Esse foi um período de grande atividade intelectual, pois os pensadores dessa época, na sua grande maioria monges, tiveram que fazer verdadeiras ginásticas mentais para poder adaptar os novos valores que surgiram com 0

20 “... ohne echtes Betätigungsfeld, mit sich selbst beschäftigte und in theatralische und pompöse Selbstbespiegelung ausartete". 
cristianismo aos velhos valores greco-romanos. Tratava-se, portanto, de “... manter a herança cultural dos antigos e moldá-las, segundo as necessidades do momento" (ibidem, p. 25) ${ }^{21}$ e, para isso a Retórica foi útil, mantendo seu espaço dentro das 'artes livres' ensinadas aos intelectuais do mundo medieval. Durante essa época, os filósofos escolásticos católicos adaptaram a lógica aristotélica, tão preocupada em comprovar verdades objetivas, para:

... justificar e ratificar a autoridade papal, hierarquia social, escravidão, lei canônica, doutrina teológica e, o mais importante, para provar a existência de Deus. Tornou-se a base do raciocínio filosófico, religioso, social, econômico e legal do Ocidente (KEY, 1993, p. 30).

Com a criação das ordens religiosas que se incumbiram de levar "a palavra de Deus" aos pagãos, a Retórica tem um novo renascimento, isto é, ela volta a ter alguma função além da reprodução teatral e ecoativa de suas regras. A Retórica Sacra se apóia na Retórica Clássica, mas oscila entre o estilo rebuscado e o gênero simples, que partia da idéia de que as 'palavras de Jesus' não precisariam ser pomposas, deveriam valer por si próprias. O grupo que apoiava esse gênero receava que a arte da oratória, apoiada sobre conhecimentos pagãos, técnicas da oratória e valores gregos, pudesse ameaçar os valores cristãos.

No Barroco, com a quebra da unidade da Igreja Católica, tem-se o renascimento de uma Retórica estimulada pelos confrontos, não só entre reformadores e a Igreja Católica, mas também Reformadores entre si, já que estes não eram um grupo homogêneo, mas dividiam-se em vários pequenos grupos. Todos lutavam - às vezes com violência, outras com palavras - por novos adeptos, procurando catequizar, ou recatequizar os já catequizados, para que 'mudassem de lado'. Os novos povos descobertos pelas grandes navegações deveriam ser catequizados para saírem de seu 'paganismo original'.

Esses catequizadores deixam-se levar pelo ideal do 'poeta possesso' pelo furor das musas (BROWN, 1971, p. 29), portanto, pouco obediente às regras

21 “... das kulturelle Erbe der Vorzeit erhalten und es an den Notwendigkeiten des Augenblicks ausrichten zu müssen". 
rígidas de uma Retórica escolástica. Ganham força os grandes sermões, de grandes oradores. É a época dos 'oradores do púlpito'. Podemos lembrar que, no Brasil, surgem Padre Manuel da Nóbrega e Padre José de Anchieta, jesuítas, encarregados da catequese por intermédio de sermões e peças de teatro e, mais tarde, Padre Antônio Vieira, entre os mais conhecidos.

No século 18, com estados absolutistas, pouco espaço sobra para discussões sobre cidadania e definição de um espaço público consensual. Só resta espaço para falas não comprometedoras, laudatórias. A Retórica adquire, novamente, um sentido pejorativo, como sendo uma fala vazia, cheia de figuras que escondem sua pouca seriedade. “... não era necessário convencer ninguém, pois não havia espaço para a dúvida, devia-se estar convencido da versão absolutista oficial da realidade" (SPANG, 1987, p. 30). ${ }^{22}$ Restrita ao espaço escolar, a Retórica perde seu sentido dialógico.

Spang afirma que no século XIX, embora a Retórica continue sendo exercida, nada lhe é acrescentada. Pelo contrário, ela se torna ainda mais repetitiva.

Gostaríamos de chamar atenção para alguns fatores que não foram levados em consideração pelo autor e que julgamos ser importantes. Mesmo nesse período, em que o autor diz ter havido pouco espaço para o exercício da Retórica como possibilidade de criação do espaço público consensual, estavam ocorrendo discussões/embates entre vários segmentos da sociedade. Todos eles buscavam defender seu espaço ou conquistar novos, validando, assim, seus pontos de vistas, sua nova posição na sociedade etc. Enquanto, por um lado, se ensinava Retórica, nas escolas, como uma 'arte pomposa e vazia de conteúdo', por outro havia um espaço real para discussões, onde se faziam representar esses grupos, além da imprensa, que começava a ganhar força como espaço público de discussão.

É nesse tempo que a industrialização definitivamente cria uma classe operária e, conseqüentemente, também uma classe burguesa fortalecida. Esta vai

\footnotetext{
22،... man brauchte niemand zu überzeugen, denn man durfte nicht, man hatte überzeugt zu sein von der offiziellen, absolustischen Version der Realität"
} 
se colocando como a alternativa de poder a uma aristocracia decadente, que precisava casar seus filhos com filhos de burgueses ricos para poder continuar tendo acesso à riqueza.

Da mesma maneira que, na Idade Média, os monges tiveram de adaptar os valores greco-romanos aos valores cristãos, terá que haver, nos séculos XVIII e XIX, um empenho muito parecido por parte dessa nova classe burguesa que está em busca de um discurso apropriado a fim de justificar seu novo espaço nas correlações de poder. Surge, então, uma Retórica parecida com a da Idade Média, no sentido de ser necessária uma 'ginástica mental' que passa a ser feita a serviço de novas justificativas, de criações de novos discursos para legitimar o acesso da burguesia ao poder.

> Boa parte dos dicionários da língua inglesa é criada nessa época, pelos filhos dessa classe que chegou ao poder e que tentava, desta forma, validar sua forma de falar (FAIRCLOUGH, 1990). Nota-se, nessa atividade, a necessidade de agregar 'capital simbólico' (BOURDIEU, 1996) ao seu modo de agir em sociedade.

O valor conferido a esse modo de agir/falar deveria passar a ser um bem que atestava o bom gosto e comprovava a distinção de quem o adotava. Esse capital simbólico tem maior poder de atuação, quanto mais ele consegue apagar a forma como foi conquistado, pois dessa forma contribui para a reprodução do status quo desejado e a sua forma de atuação e perpetuação permanece oculta, portanto, indiscutível (HARVEY, 2004, p.81).

$>$ Brown (1971) também afirma que nessa época houve verdadeiros debates nos jornais, que estavam se firmando como meios de comunicação de longo alcance, nos quais alguns grupos expunham a importância da emergente classe burguesa, que com seu "trabalho" agia como criadora de riquezas para o país, argumentando que este estava cansado de viver sustentando nobres que por sua vez eram chamados de 'preguiçosos', já que viviam de rendas.

E, logicamente, havia o discurso do grupo dos que tentavam manter os privilégios da nobreza, que estava perdendo seu status. Havia, também, o discurso concorrente do grupo dos que já percebiam a burguesia como uma nova 
classe exploradora dos trabalhadores. Um novo ideal do ser humano é oferecido para uma nova época.

Naturalmente, esse ser ideal passa a ser o indivíduo empreendedor, na pessoa do comerciante, do empresário industrial, que através de seus negócios, de seu comportamento, enriquece uma pequena parte da população inglesa. Costa Lima (2002) cita os jornais Spectator e Tatler, nos quais ocorrem exemplos dessas idéias. Como se pode ver, muita retórica teve que ser usada para se argumentar a favor de cada grupo e, conseqüentemente, em detrimento dos outros.

$>0$ positivismo também chega com seus valores, pregando a ciência e 0 experimentalismo como a grande panacéia para as dúvidas e problemas da humanidade, com uma explicação 'científica' para tudo, pleiteando pouco espaço para a criação do mundo através do discurso, pois, segundo o experimentalismo, este falsearia a realidade (Baccega, 1998).

Não há, nesse tempo, a necessidade da Retórica, enquanto 'exercício pomposo', pois essa vai contra a ciência. Isto se for encarada como o poder de exercer a sedução do auditório por meio da palavra. Surgem, porém, com a efervescência provocada pelo que está sendo descoberto, pesquisado, novos conhecimentos que necessitam ser repassados. A princípio, estes eram divididos entre cientistas e seus pares por intermédio de cartas que se escreviam para se atualizarem e colocarem suas descobertas à prova. Com certeza foi necessário, além de cálculos, saber argumentar para convencer de que suas descobertas eram válidas.

No século XX, a Retórica une-se à filosofia, à teoria da comunicação, e a outros campos de criação. Começa novamente a ser levada mais a sério. Trata-se de cada ciência, campo de atividade específica, criar suas próprias justificativas de existência, criando não apenas uma nova rede de conhecimentos, mas também formas de controle de sua propagação, que se expressa na sua forma de referir-se a seus conhecimentos. Criam-se formas de falar sobre determinados conhecimentos que se tornam quase esotéricos. Estas são formas de detenção de poder nas mãos de seus criadores e divulgadores. 
Com movimentos chamados de Nova Retórica, busca-se dar novos rumos para a Retórica. Esta continua seguindo duas grandes tendências: especialização, por um lado, na busca de um trabalho conjunto com ciências como Lingüística, Psicologia, Sociologia, buscando um aprofundamento das mesmas; e pragmatismo, de outro, passando a ser uma categoria de análise, um 'instrumental' para se analisar textos dos mais diversos campos e origens, agora sem o caráter normativo que Ihe foi atribuído pelo ensino nas escolas ao longo dos séculos.

Se o objetivo da argumentação é obter a adesão, como foi dito, ela busca impedir argumentações contrárias. Mas, como o espaço de discussão é aberto, e como as práticas que interagem na sociedade são quase infinitas, não há a possibilidade de um discurso definitivo. Nem ao menos um discurso no qual todas as reações sejam, supostamente, previstas. Os efeitos de sentido provocados pelos discursos não podem ser controlados, pois o ato de interpretar é um ato criativo, participativo.

O indivíduo que aceita as conclusões de uma argumentação é responsável por ela. Como afirma Perelmann, para o fanático, a verdade será absoluta e para o cético, a verdade será impossível. Pois ambos, como afirma o autor, "... negam essa função da argumentação em nossas vidas" (PERELMAN; OLBRECHTSTYTECA, 2002, p. 69). Recusam-se a reconhecer o poder da argumentação como espaço político, como a escolha entre possíveis acordos, nos discursos que coexistem em sociedade. Ambos dão campo à violência, pois nesse pensar dicotômico não há espaço para a razão coercitiva. Ambos formam as duas faces da mesma moeda, a moeda da troca do autoritarismo.

Existem nesses dois níveis de funcionamento premissas fundamentais aceitas a priori. Há uma suposição implícita para o fanático de que o que é dito é absolutamente claro, verdadeiro, sem espaço para dúvidas; para o cético, isso é absolutamente impossível. Mas se a linguagem é justamente o espaço de relações e negociações de sentidos, nas quais o ser humano é capaz de coordenar ações em sociedade, é necessário que esses sistemas 'racionais', 
montados em cima de obviedades inquestionáveis, sejam justamente focos de reflexões.

Do discurso de atuação participativa dos cidadãos em diversas épocas ao vazio em épocas de menor liberdade, o que se revela é que existem gradações entre os dois e todos podem ter funções dentro das sociedades. De qualquer forma, o ser humano precisa da retórica para poder criar suas práticas sociais, seus sistemas de valores e verdades. Ao fazer isso, tem-se que reconhecer o outro, o interlocutor como seu companheiro de criação do meio em que, conjuntamente, vivem. Tem-se que negociar a instauração de sentidos e de interesses que nem sempre convergem.

Os anúncios publicitários são estudados, neste trabalho, como a criação de uma rede de vozes, na qual é possível, por intermédio de análises do material lingüístico, expresso na superfície, juntamente com o estudo das possibilidades dos efeitos persuasivos da retórica, da composição das imagens e de outros fatores que os compõem. Por isso nosso interesse por publicidade, na medida em que esta é vista como um espaço de agir estrategicamente orientado para o sucesso de quem a produz e/ou de quem paga por ela e na qual o seu interlocutor é visto como alguém a ser seduzido por uma argumentação. Um agir estratégico que leva marcas culturais próprias de cada espaço onde é criado e a mais pragmática de todas as retóricas, justamente porque opera em função de um mercado.

\subsection{Retórica e publicidade}

A peça publicitária veiculada pela imprensa escrita é muito complexa, principalmente pelo fato de unir dentro de tão pequeno espaço que é um anúncio, elementos de campos tão diferentes, como seu código lingüístico (título, texto, slogan), sua composição visual (lay-out, fotografia/imagem, cores, tons, tipologia etc.), o local da revista onde é inserida, a sua relação com os outros itens da revista, além dos elementos temáticos nos quais baseia sua narrativa. 
Tanto nas regras montadas por Aristóteles, como nas regras montadas pelos publicitários atuais, podemos detectar muitos pontos fundamentais semelhantes. E se na retórica antiga, pregada pelos sofistas, a meta era a "adesão dos espíritos", mais do que nunca esse continua sendo o desejo dos anunciantes.

Não se trata, porém, de uma simples retomada dos mesmos princípios de 2500 anos atrás. No mundo atual, onde a separação espacial e temporal parece ficar cada vez menor e no qual grande parte dos cidadãos tem a sua disposição um conjunto de bens e informações oriundas de quase todas as partes do globo terrestre, ocorre um processo de saturação, principalmente de imagens. Estas talvez já não consigam mais despertar o leitor/consumidor como antigamente, o que acarreta, por parte dos anunciantes/publicitários, um constante adaptar-se a novas tecnologias retóricas, além de inovações cada vez mais agressivas e inéditas para atrair a atenção.

Até nas sociedades ditas da modernidade, vivia-se em grupos identificáveis com classes, com mobilidade limitada entre si. Hoje, por outro lado, vive-se no anonimato das massas e, ao mesmo tempo, em uma sociedade cada vez mais atomizada em miríades de grupos, 'tribos' compostas por indivíduos que se interrelacionam por interesses os mais diversos, onde cada um interage com o outro mais por área de interesses do que apenas por classes.

Os seus desejos, muitas vezes, são os de seus inúmeros grupos de referência e não apenas os de sua classe social. Interesses muitas vezes, os mais diversos e especializados. O mesmo indivíduo pode fazer parte de um grupo de esportes radicais, e ao mesmo tempo fazer parte de um curso de culinária ou enologia e de cinema. Para cada um deles a publicidade terá um discurso sedutor apropriado, provavelmente com uma forma de abordar que respeite diferentes regras etc.

Mesmo com todas essas mudanças, algumas regras da retórica continuam a ser observadas. Entre elas a de que todo discurso - em nosso caso, toda peça publicitária - é criado em função de um público. O que importa é que existe na cabeça do produtor do texto um modelo de interlocutor no qual ele pretende 
interferir com sua argumentação (PERELMAN; OLBRECHT-TYTECA, 2002). Seja o grupo de esportes radicais ou o de enologia.

Não é necessário que se trate de um grupo real, mas de uma imagem que se tem de um determinado grupo. A publicidade não vive, hoje, sem as pesquisas de opinião dos grupos que quer convencer, pois em questão da retórica publicitária não há nada mais falho do que usar argumentos errados, na tentativa de convencer alguém.

A grande meta da publicidade, que é conseguir influenciar na aquisição do produto/serviço, por intermédio das mais variadas técnicas, já vem sendo usada de diferentes maneiras desde a antiguidade. O condicionamento do público por meio de "numerosas e variadas técnicas que utilizam tudo quanto pode influenciar o comportamento" (ibidem, p. 9) não é, absolutamente, uma idéia nova.

Para a publicidade, cuja primeira preocupação é o resultado - seja este traduzido diretamente na venda do produto/serviço seja ou na lembrança da existência dele ou da marca -, não basta o convencimento, que nem sempre se traduz na ação. É necessária a persuasão. E, para alcançar esse objetivo, Carvalho deixa bem claro:

Os recursos estilísticos que a mensagem publicitária adota correspondem em geral à retórica, tipo de discurso voltado para examinar, descrever, perceber e avaliar atos e eventos que venham a influenciar percepções, sentimentos, atitudes e ações, com palavras empregadas de forma diferente do uso comum, literal. Usar os recursos retóricos é usar a comunicação para definir a realidade do modo como se deseja que ela seja vista (CARVALHO, 2003, p. 74).

Alguns autores buscam diferenciar o ato de convencer do de persuadir. No primeiro a argumentação é dirigida à razão por meio de um raciocínio lógico e provas objetivas, levando a conclusões que são tiradas por intermédio de premissas óbvias (PERELMAN, 2000). Este ato de convencimento tem como alvo um auditório universal, pois trabalha com o conceito de 'verdade inabalável', algo que é válido para uma grande maioria. 
Mesmo assim, achamos que não se pode esquecer que essas 'verdades inabaláveis', 'racionais', às vezes se chocam umas com as outras ao longo do tempo, e, às vezes, ao mesmo tempo. Portanto esse conceito de 'ser dirigido à razão' é mais voltado para o que é verdade para o maior número de pessoas, em um determinado tempo.

Podemos dizer, buscando uma diferenciação entre convencimento e persuasão, que o discurso persuasivo busca a empatia, procurando despertar sentimentos no interlocutor, atingir sua vontade, não com argumentos baseados em 'verdades', mas por intermédio de argumentos verossímeis, de acordo com o tempo, espaço e história onde é proferido. Busca a adesão pelo sentimento.

Enquanto $O$ ato de convencer tem como alvo um auditório universal, 0 segundo almeja ser válido para um 'auditório particular' e “... chamar convincente àquela [argumentação] que deveria obter a adesão de todo ser racional" (ibidem, p. 31). A tipologia itálica em "convincente" é do próprio autor e nos chega como ironia, pois indica o valor que o próprio orador dá à sua argumentação. Logo em seguida, ele justifica o uso do itálico. "Cada homem crê num conjunto de fatos, de verdades, que todo homem 'normal' deve, segundo ele, aceitar, porque são válidos para todo ser racional". Voltamos a frisar: a palavra "normal" entre aspas também é do próprio autor.

Vem-nos à mente a verdade inabalável, até a Idade Média, de que o sol girava ao redor da terra. Nenhum homem "normal" nessa época ousaria pensar diferente. Até que Copérnico fez os primeiros cálculos, provando o contrário e Galileu, mais tarde, resolveu publicar seus estudos baseados nos mesmos resultados. E a "verdade inabalável" passou a ser outra. Não nos faltam exemplos na história da humanidade de "verdades evidentes" que vieram a ser mudadas com outras vivências e experiências.

Não é possível traçar uma diferença tão clara entre o que seja convencer e persuadir. Diminui também a diferença entre a definição do que seria um auditório geral ou particular, pois mesmo numa determinada época e lugar o auditório geral raramente é homogêneo, dadas as muitas práticas sociais nas quais todos os indivíduos atuam na sociedade. Por isso mesmo, contra os que não se sujeitam ou 
não se convencem dessas "verdades claras", ou não se "ajustam", usa-se o recurso, ainda muito atual, de uma lógica baseada na exclusão, desqualificando ou diminuindo-os como 'loser', 'Versager' ou 'perdedor' ou mesmo 'anormal' etc.

Como mecanismos de ajustes podem ser citadas instituições como escolas, igrejas, reformatórios ou a indústria farmacêutica e seus medicamentos psicotrópicos. "Psiquiatras e professores cada vez mais vêem o ideal da normalidade no "ajustamento social" (sem se perguntar "a que" se ajusta o indivíduo)" (BROWN, 1971, p. 34).

O curioso é que, com toda essa preocupação de ajustamento do indivíduo à sociedade, tudo o que a publicidade faz é dizer o quanto o usuário do produto anunciado é único, especial, diferente, pertencente a uma classe de pessoas especiais, acima da média.

A função da Retórica seria a busca de uma ação entre esse público ao qual se dirige a argumentação, e para isso tenta provocar a empatia de forma a desencadear uma ação pretendida pelo orador.

Aristóteles categorizou os gêneros oratórios em:

$>\quad$ deliberativo, que aconselha ou não uma ação futura, aconselha 'para o útil, ou seja, o melhor': orienta para uma decisão sobre vantagens ou desvantagens;

$>\quad$ judiciário, acusa ou defende, 'pleiteia o justo'. "Ocupa-se com assuntos ainda não decididos”. Orienta-se para coisas já ocorridas. Trata-se de convencer alguém para que faça um julgamento; epidítico, não exige decisão ou julgamento nenhum, louva, raramente censura, trata do 'belo ou feio'. É parcial, não tem compromisso com o justo ou o melhor. Para atingir seus objetivos usa do argumentos erísticos.

Para o filósofo, o que caracteriza a argumentação erística, em distinção aos outros três tipos de argumentos que ele enumera: didáticos, dialéticos e críticos, é que a primeira se vale de: “...; argumentos contenciosos (...) que raciocinam ou parecem raciocinar a partir de opiniões que parecem ser geralmente aceitas ... “(ARISTÓTELES, 1983, p.156). Aparecem, segundo 
Perelman (2000, p.43), no diálogo que tem por objetivo “... dominar o adversário, (...) persuadir seu auditório com o intuito de determinar uma ação imediata ou futura".

Os argumentos usados se apóiam no pressuposto de concordância, impedindo chances de possíveis respostas contrárias. Realçam apenas qualidades positivas, usam de mecanismos lingüísticos e argumentativos que acionam esses pressupostos de concordância, fazendo uso de argumentação que visa a tornar difícil o questionamento do que é afirmado. É um agir estratégico. Nessa forma de argumentação, procura-se negar ao outro a possibilidade do exercício de um posicionamento crítico e participativo na interação, visando-se aos próprios interesses e não a um agir cooperativo que procura o entendimento mútuo.

O que predomina em publicidade é o gênero epidítico/demonstrativo e a argumentação erística, preponderantemente, a laudatória, a exaltação do bom, belo e de outras qualidades que possam ser consideradas vantajosas. Elogia-se a todos, fabricante, produto, consumidor, procurando sempre, levar a um possível desejo de aquisição ou à lembrança da marca.

Os ouvintes/leitores se atêm a servir de espectadores e a aderirem ou não aos argumentos. Uma simples análise do tipo de adjetivos que mais aparecem em anúncios nos mostrará uma alta incidência de termos de avaliação positiva. A publicidade visa à ação futura, podendo resultar ou não na aquisição de algo. Procura espetacularizar as situações de forma a atingir o auditório pela empatia. Como foi dito acima, o tipo de discurso utilizado buscará fundamentar-se, na maioria das vezes, em valores já reconhecidos pelo auditório como sendo de prestígio. Reconhecidos e aceitos pelo menos pela maioria, de senso comum, ou tentando passar a idéia de que já faz parte do senso comum. O gênero epidítico traz embutida a negação do que lhe é diferente, concorrente.

Esse tipo de discurso composto de negação, do silenciamento do outro, não é exclusivo da publicidade. Os discursos institucionais, que têm o respaldo das instituições que representam, estabelecem a validação de determinados tipos de saberes, impedindo outros, não reconhecidos pela própria instituição, de vir à 
tona. Foucault $(1991,2002)$ em seus trabalhos demonstra que 'verdades' vão sendo inseridas ou apagadas, dependendo das exigências do desenrolar da História. Esses apagamentos produzem saberes, muitas vezes, "inquestionáveis", seja em discursos institucionais, como no senso comum.

Por isso, geralmente, o discurso epidítico apóia-se em valores comuns, em valores que, embora não sejam claros, são aceitos como certos, compartilhados em silêncio, e inconscientemente pela maioria da comunidade que a ele tem acesso.

Não buscam mudanças, mas justamente o reforço do que já é aceito. Busca-se, por meio desses valores, a adesão do público, evitando provocar dissonâncias cognitivas ou qualquer fator que possa provocar a rejeição do que é mostrado no anúncio como parte do inventário perceptual ao qual a marca quer ser ligada. Para isso, muitas vezes, vai-se buscar motivos arquetípicos, mitológicos, comuns a uma grande maioria de indivíduos e que estão no inconsciente coletivo da humanidade desde tempos remotos, e que podem ser manipulados com os mais diversos objetivos. Esses acordos 'inquestionáveis' são discutidos como possibilidades de sobrevivência da sociedade enquanto tal.

Aglietta (1990), discutindo esses "acordos" a partir dos quais surgem as instituições na sociedade, coloca os acordos, as instituições como sendo o resultado da socialização dos indivíduos. São esses 'contratos' que viabilizam o surgimento da cultura e da sociedade. Mas afirma, também, que esses acordos não ocorreram nem ocorrem de maneira assim tão pacífica como pode parecer.

A sua soberania advém de sua ação como uma mediadora de conflitos. Este autor os coloca como sendo uma "violência fundadora que institui o conjunto" (os acordos que possibilitam o surgimento de instituições que viabilizam a convivência). Só que esse 'acordo' não está livre da rivalidade inicial, que é justamente a causa de sua busca. Eles surgem como os intermediadores das relações de poder e legitimam o poder do mais forte, mas, aparentemente cedem também algo ao mais fraco, de forma que este aceite sua criação.

Aglietta (1990, p. 57) afirma: “..., considera-se admitido que toda ordem social é fundada na violência..." e se propõe a compreender como essa violência 
inicial é justamente o mecanismo que pode engendrar a coesão social, evitando que os grupos, com desejos tão diferentes, se engalfinhem até sua destruição mútua.

Dessa forma torna-se mais compreensível a afirmação de Bakhtin (1995) de que o signo é uma 'arena' onde lutas em busca por estabelecimento de significados ocorrem, assim como o conceito de hegemonia, que vê a aceitação da dominação de muitos por uns poucos como sendo uma barganha, em que os dominados cedem em troca de que pelo menos algumas de suas exigências sejam satisfeitas.

Essa comunhão de espíritos, em sociedades já democratizadas, que já ultrapassaram estágios abertamente violentos, vai ser buscada por intermédio da argumentação. Não há mais a necessidade de punhos ou martelos, mas o poder misteriosamente ambíguo das palavras que fazem as coisas terem sentidos e mudam o mundo.

A análise da argumentação é, justamente, sobre o que se admite como sendo acordado entre os interlocutores, a quem se destina a proposição, sobre o ordenamento e encadeamento dos argumentos e sobre que tipo são, que tipo de adesão se busca, que aspectos são realçados, quais são apagados, em que ordem ocorrem, com qual objetivo estão nessa ordem, que tipo de ordenação do real se busca, quais efeitos de sentido previstos ou imprevistos provocam etc.

Em relação a esses acordos feitos pelos interlocutores, Perelman; Olbrechts-Tyteca (2002) chamam a atenção para o fato de que há diferentes tipos deles e eles vão interferir no processo da argumentação. Ele os agrupa em duas categorias, a do real e a do preferível.

No primeiro grupo, do real, ele coloca os fatos, verdades e presunção. Esse grupo "tem pretensão de validade universal". Discutimos acima que mesmo esse real varia de acordo com fatores diversos.

$>$ Fatos - objetos de acordos precisos.

> Verdades - sistemas mais complexos, relativos a ligações entre fatos.

> Presunções: 
- de qualidade - 0 ato manifesta a pessoa que o fez (o que é feito pela pessoa leva a pensar em como a pessoa 'é', a qual grupo se filia, que possível status detém). Esse recurso é usado em publicidade, pois os ethé aos quais se ancoram os personagens devem ser reconhecidos pelos leitores para que seja possível sua identificação junto ao que é propagado pelos anúncios.

- de credulidade natural - não se tem motivo para duvidar. Essa é uma das bases fundamentais do discurso didático: acredita-se que o professor está ensinando a verdade (mesmo porque, quem não acreditar recebe um zero). No caso da publicidade, parte-se do princípio de que existe uma ética que afirma não ser correto anunciar algo que não condiz com a verdade. Por extensão desse acordo, o texto escrito, que poucas vezes é lido pelos leitores, compõe a imagem como um ícone de fidedignidade a corroborar essa credulidade. Ele vale pelo simples fato de estar presente (ZIELKE, 1991).

- de interesse - concordamos com o que teoricamente nos interessa (geralmente acreditamos no que nos interessa, no que está de acordo com nossas crenças). Daí a necessária audácia, cada vez maior, dos anúncios publicitários em chamar a atenção do consumidor. Pois em meio a tantos estímulos, é difícil atrair o interesse do leitor.

- de caráter sensato - Entra nesse item o papel fundamental dos frames, scripts cognitivos, que permitem que se reconheça o que está sendo veiculado e que exigem uma certa verossimilhança cultural das narrativas apresentadas.

As presunções dependem do que é considerado "normal e/ou verossímil", pelos grupos de referência. Estes são grupos aos quais nos ligamos durante a vida, que são muitos, dada a complexidade da vida atual, ex.: família, escola, amigos, sindicato, trabalho, vizinhança, clube etc. (BROWN, 1971). Ocorre que todo ser humano acredita num conjunto de fatos, acontecimentos, relações que, segundo eles, todo indivíduo 'normal' deve aceitar, porque, aparentemente, são 
válidos para todo ser racional. Isso faz parte de mecanismos que mantêm os grupos coesos.

No segundo grupo de acordos, Perelman e Olbrechts-Tyteca colocam os valores, hierarquias e "os lugares do preferível". Este grupo está ligado a restritos pontos de vista e auditórios particulares, pois são dependentes da diversidade de grupos existentes. A publicidade pode fundamentar seus argumentos tanto com acordos do primeiro grupo como do segundo, dependendo do tipo de público do qual busca a adesão.

Concordar com um valor é concordar que numa argumentação determinado aspecto sobre o qual se argumenta não é válido para todos, mas só para o grupo ao qual se dirige. Por isso é aceita a existência de grupos com valores diversos, ainda mais em sociedades organizadas de maneira tão complexa como as sociedades pós-modernas, com sua multifacetada composição e seus modos particulares de ações. Segundo esses autores (2002, p. 84): "Recorre-se a eles para motivar o ouvinte a fazer certas escolhas em vez de outras, e sobretudo, para justificar estas, de modo que se tornem aceitáveis e aprovadas por outrem".

O problema é que essa diferenciação nem sempre é tão facilmente feita. Como já foi discutido anteriormente, muitas vezes o mesmo enunciado, dependendo de seu posicionamento no momento histórico, dependendo do apoio, reforço ou negação que recebe de outros discursos concorrentes, em que busca se apoiar para tornar-se válido, poderá ser interpretado como pertencente ao primeiro grupo de acordos, os que pleiteiam 'validade universal' ou simplesmente ao que se considera uma questão de valor.

O que também pode ocorrer é que valores de grupos muito mais poderosos que outros se estabeleçam como fatos ou verdades inquestionáveis para outros grupos menos poderosos (LAKOFF; JOHNSON, 2002) ou que os valores se assemelhem, porém sejam hierarquizados de maneira diferente. Não será discutida, neste trabalho, a distinção que o autor faz entre valores concretos ou abstratos, já que, pelo que foi esboçado acima, este trabalho considera que todo valor é fruto de acordos. 
É importante respeitar esses acordos nas narrativas publicitárias a fim de não provocar 'dissonância cognitiva', que ocorre quando as identidades ou personalidades projetadas nas marcas, produtos ou serviços entram em conflito com o que os possíveis consumidores consideram como sendo acordado entre si ou na forma como desejam ser representados nos anúncios ou campanhas publicitárias (RANDAZZO, 1997). O que já faz parte de nossa estrutura cognitiva é mais facilmente assimilável, aprendida.

A argumentação se baseia, também, em hierarquias que introjetamos, na maioria das vezes sem perceber. O indivíduo, inserido em um tempo/espaço dentro de sua comunidade, aprende, inconscientemente, a articular características, sinais que levam a perceber igualdades ou diferenças e com eles passa a diferenciar, reconhecer, escolher etc. elementos do seu entorno necessários à sua sobrevivência ou interesse.

Isso adquire valores que tendem mais para o positivo ou naturalmente seus para os seus pólos opostos negativos, dentro de seus grupos de referência que formam a base de seu sistema de avaliação, que muitas vezes se pretende objetivo. É um sistema perceptual de práticas sociais que fornecem esses parâmetros, que vão 'fabricar' o referente, provocando a ordenação do que é real. Isso fica muito claro na publicidade ao nos depararmos somente com termos positivos ou meliorativos em relação aos produtos anunciados.

Blikstein fornece alguns exemplos do que chama 'corredores isotópicos' :

... que recortam o universo de formas, cores, e espaços, em nossas comunidades ocidentais: superatividade (meliorativo) / inferatividade (pejorativo), frontalidade (meliorativo) / posterioridade (pejorativo), retitude (meliorativo) / tortuosidade (pejorativo), (...) branquitude (meliorativo) / negritude (pejorativo) etc "ou os seres humanos superiores aos outros animais etc. (BLIKSTEIN, 1985, p. 61).

É desse mecanismo que, também, se alimenta a argumentação erística. Uma argumentação construída a partir do que é encarado como positivo pelos grupos que pretende seduzir. Esta forma de busca por empatia é feita, sempre que possível, tornando esses argumentos como já fazendo parte do senso comum 
e, portanto, evitando contra-argumentações. A argumentação erística pode ou não ser baseada no senso comum, deve, porém, parecer estar de acordo com ele, de modo a não causar dissonâncias cognitivas.

Nada impede, porém, que a publicidade subverta essas e outras 'normas', sempre que achar necessário, viável e lucrativo.

Resta-nos a categoria dos acordos dos lugares preferíveis. Era o que os Sofistas pesquisavam com tanto afinco. $O$ arsenal indispensável de lugares comuns e específicos, os topoi, que qualquer bom orador deve ter às mãos quando quiser persuadir alguém. Como o nome já diz, os comuns baseiam-se na lógica da cotidianidade (NEUMANN, 2001), no senso comum e se adaptam a qualquer campo e os específicos ficam restritos a seus respectivos campos. Esses últimos são usados para platéias mais seletas que fazem parte de grupos de iniciados em determinados conhecimentos.

Tanto os primeiros como os segundos, como o próprio nome já demonstra, são "lugares", encontram-se abertos para as mais diversas interpretações de acordo com o desejado, são argumentos que servem de acordo com a situação e podem ser usados tanto para reforçar um argumento quanto para negá-lo.

O texto de Nando Reis, analisado no anúncio da Pfizer brasileira, é um exemplo da opção pelo uso de lugares-comuns, a fim de provocar a 'adesão do espírito' da maioria das pessoas que vivem o desejo de uma vida cujo sonho de felicidade está de acordo com o ideal da chamada sociedade burguesa. Assim como as publicidades da BASF servem como exemplo do uso de lugares específicos, com termos técnicos que colonizam seus anúncios de modo a lhes dar maior seriedade junto aos leitores.

Se a argumentação publicitária tem como objetivo claro buscar a adesão dos espíritos e por esse motivo se restringe basicamente à louvação da instituição/mercadoria/serviço que anuncia, é de se esperar que, como uma forma de economia de espaço e tempo, ela lance mão, com muita freqüência, de lugares-comuns e de valores aceitos pelo grupo alvo. Dessa forma, não sobrecarrega a capacidade de interpretação do leitor e ancora-se de imediato no que já é conhecido. 
Todos os anúncios têm limitações que Ihes são intrínsecas. Eles dependem da atenção e interesse do receptor, dependem do espaço onde são colocados, do tempo 'comprado' à mídia e do tempo que o leitor/ouvinte/consumidor tem disponível para eles. Por conta desses fatores o anúncio publicitário tem como característica ser conciso. Essa característica não se dá somente porque o espaço onde ele ocorre é caro ou pequeno, mas também porque o seu público tem que ter sua atenção "seqüestrada" nos poucos segundos que leva para percebê-lo.

Pode-se chamar a atenção também para o fato de que a própria percepção dos anúncios pode ter nuances culturais. Segundo Müller (1997, p. 79), essas diferenças culturais podem influenciar na reação ao anúncio, fazendo com que ele seja mais ou menos 'percebido', provocando, dessa forma, um maior ou menor envolvimento do receptor. A mesma autora fornece exemplos de países onde publicidade é 'consumida' de forma diversa. Na Alemanha, ela é vista como "persuasão velada", na França e na Inglaterra, como uma forma de "diversão".

Essa predisposição, em relação à informação que chega por intermédio de anúncios, influencia a forma com que essa informação é transformada em atitude. Atitude, segundo Fishbein; Ajzen, é: "uma predisposição aprendida para responder de uma maneira favorável ou não com respeito a um dado objeto" (apud MÜLLER, 1997, p. 79) ${ }^{23}$. Como já foi dito anteriormente, essas diferenças culturais e sociais devem ser respeitadas nas narrativas publicitárias a fim de não provocar dissonância cognitiva.

Se os profissionais da publicidade não conseguirem atingir e "seqüestrar" a atenção do consumidor nesse pouco espaço/tempo a seu dispor, eles falharam. Portanto, passa a ser fundamental o modo e a forma como a informação será apresentada ao interlocutor, o consumidor.

O esquema básico detalhado por Aristóteles, que será retomado na discussão sobre a estrutura do anúncio publicitário é o seguinte:

1. Inventio - a invenção do assunto sobre que se vai falar.

\footnotetext{
23 "a learned predisposition to respond in a consistently favorable or unfavorable manner with respect to a given object".
} 
2. Dispositio - a organização dos argumentos, encadeamento lógico do falar, subdividida em:

$>$ Exordium - entre outras funções, introduzir o assunto, captar e manter a atenção, angariar simpatia;

$>$ Narratio - esta parte é subdividida em outras três:

-enumeratio = detalhes sobre 0 assunto;

- argumentatio = as argumentações, a parte mais importante da apresentação;

-digressio = o espaço da tomada de posição pessoal;

> Peroratio - é a finalização, funciona como um apanhado do que foi dito e, mexendo com o sentimento do auditório, tenta induzir o ouvinte para a conclusão desejada, o epílogo. No sistema aristotélico, compõe-se de quatro fases: 'predispor o ouvinte'; 'reforçar ou atenuar'; 'excitar paixões'; 'recapitular'.

3. Elocutio - de que forma essas idéias serão colocadas em material lingüístico ou no caso dos anúncios, qual tipo de composição será feita entre os elementos representativos que compõem a publicidade. Aí entra tanto a criatividade do orador, como também seus conhecimentos sobre alguns critérios de qualidade lingüística, regras gramaticais, pronúncia, clareza na exposição, o elemento estético (ornatus), como também, respeito ao público a que se dirige, adequando-se ao contexto social. Um conhecimento que permita, inclusive, quebrar algumas destas regras para atingir o efeito desejado, como é tão usual na publicidade.

Obviamente, cada necessidade de persuasão, cada público, cada ocasião etc., clamará por um estilo. Tanto os 'lugares' como as figuras retóricas que vão concretizá-los materializam-se nesse momento, de acordo com a necessidade de persuasão e público. É a manipulação criativa desses elementos que permite uma constante renovação da fala e possibilita que esta continue sempre atraente. E o que não falta à publicidade é criatividade.

4. Memória - Se na Grécia Antiga o falante era dependente de sua capacidade de reter o maior número de tópicos possíveis em sua memória e estar 
pronto a usá-los de acordo com a necessidade, atualmente o orador tem acesso a outras formas de arquivos, mais fáceis de serem acionados.

5. Actio et pronuntiatio - o que interfere no momento da atuação. É a atualização do discurso. Tudo o que tem a ver com sua presença física: gestos, pronúncia cuidada ou formas gramaticais escolhidas, vivacidade, a forma de se apresentar, a vestimenta.

O esquema estratégico apresentado acima não ocorre de forma linear. No momento em que o discurso se materializa em fala, todos esses elementos coocorrem.

Levando em consideração o que foi discutido anteriormente sobre o funcionamento da linguagem, parece-nos evidente que uma prática social dialógica não ocorre num vácuo têmporo-espacial e é, portanto, determinada continuamente por interesses conflitantes, atuando de maneira nem sempre clara. Também nos parece impossível não levar todos os passos do esquema acima citado em consideração.

Estes aspectos serão tratados no decorrer da pesquisa, de acordo com a necessidade de mencioná-los. Nessas campanhas, os elementos lingüísticos, as fotos e outras imagens, cada um de seus detalhes são muito bem planejados e intencionalmente colocados. A imagem vai ser de capital importância para a publicidade. É a forma mais rápida que os anúncios utilizam para começar a veicular o ethos, a identidade social de cada indivíduo, que se manifesta por intermédio de um cruzamento entre sua fala, seus gestos, sua postura, seu comportamento etc. (CHARAUDEAU, 2006). Tudo isso importa para dirigir o ouvinte à produção de sentidos.

Se, como vimos, a retórica e com ela as melhores formas de persuadir os indivíduos têm sido motivo de estudo há muito tempo, a publicidade, da forma como a conhecemos hoje, é a forma mais invasiva de persuasão retórica. 


\section{PUBLICIDADE}

\subsection{O que é e para que serve}

O que é publicidade? Isso parece estar intuitivamente claro para todos. $\mathrm{O}$ poeta Ferreira Gullar (2005, p.15), por exemplo, descreveu-a, em sua coluna semanal na Folha de São Paulo, como "um mecanismo para que todos fiquemos atolados nos juros de crediários, cartão de crédito ou cheques especiais". Esse tema, no entanto, será tratado, aqui, do ponto de vista da ciência da informação, portanto, de uma maneira menos intuitiva.

Propaganda se origina, de acordo com Brown (1971), do latim arcaico 'pangere', que era uma técnica de plantio por intermédio de mudas, e deu origem ao verbo 'propagare' que significa semear, espalhar sementes para que germinem. Segundo Oliveira (1996, p. 69) e outros autores, o Papa Clemente VIII e a Igreja Católica, a fim de 'semear' e defender a fé estabelecida por ela, cria a "Congregatio De Auxilibus", em 1597. Tanto por conta de novos mundos descobertos - portanto, com "muitas almas a serem catequizadas" -, como para fazer frente aos movimentos reformadores da Igreja. A partir da Congregatio De Auxilibus, é instituída a Congregatio de Propaganda FIDE (congregação da fé que deve ser propagada), instituída em 1622, pelo Papa Gregório XV. Vale ressaltar que essa instituição, mais conhecida como o 'Santo Ofício' ainda hoje continua impondo ordem de 'silêncios obsequiosos'.

E já que esse trabalho é uma comparação entre publicidades brasileira e alemã, vale lembrar que o atual Papa Joseph Ratzinger, alemão, foi o 'prefeito' dessa instituição nos últimos 20 anos, impondo 'silêncios' a vários teólogos, entre eles o alemão Hans Küng, e o brasileiro Leonardo Boff.

A palavra "propaganda", por ter essa origem estabelecida como sendo a educação para uma idéia (fé, juízo de valores etc.), foi e ainda é usada para definir a publicidade não comercial, aquela organizada por instituições governamentais, religiosas, políticas, a serviço da propagação de idéias e ideologias, a serviço de grupos específicos. Às vezes ela é apresentada como comunicação de idéias 
entre instituições e cidadãos que tentam "... induzir em outros a aceitação de uma crença específica sem dar razões por si mesmas evidentes ou lógicas para essa aceitação, quer elas existam ou não" (BROWN, 1971, p. 26).

Segundo Carvalho (2003, p. 10), "a propaganda (institucional, religiosa, ideológica) está voltada para a esfera dos valores éticos e sociais. “

Um bom exemplo de propaganda, de pelo menos três mil anos, é a famosa Pedra da Roseta, descoberta por arqueólogos de Napoleão Bonaparte, por ocasião de sua invasão do Egito. É um pedaço de rocha basalto que fazia parte dos monumentos erigidos por volta de 136 a.C. em homenagem ao faraó Ptolomeu. Essa pedra contém inscrições em três línguas: os hieróglifos egípcios; o demótico; e a língua grega. Como ela contém as três línguas e todas estas contêm o mesmo texto, os hieróglifos e o demótico puderam ser traduzidos e enigmas de três mil anos puderam ser resolvidos. Esta pedra, que foi uma espécie de propaganda, possibilitou a tradução e o desvendamento de parte da cultura egípcia.

Nota-se aí, que, como esse monumento era destinado a fazer propaganda do faraó, e, portanto, deveria alcançar um maior número de pessoas, houve a inclusão do demótico, que era de uso vulgar, além dos hieróglifos, que era a língua mais restrita aos sacerdotes e à nobreza. Pretendia-se atingir, com essa propaganda, os deuses, o povo egípcio e também os gregos, os quais, na época, pertenciam à dinastia desse faraó.

Também na Babilônia, foram encontrados ladrilhos comemorativos de obras realizadas pelos reis da época (GOMES, 2003). A exemplo do que fazem, atualmente, as placas indicativas de obras realizadas por políticos no poder.

Podem-se citar, ainda, propagandas da época da mais recente ditadura brasileira - a de 1964 a 1989 - quando o governo desenvolveu campanhas para conquistar o apoio da população, tentando criar sentimentos de patriotismo e tolerância com as ações de tortura e banimentos de cidadãos. Lançaram-se, então, slogans como: 'Amazônia: integrar para não entregar', 'Brasil: ame-o ou deixe-o' e 'Pra frente, Brasil!" 
Já a publicidade é uma "propaganda comercial" de produtos e serviços dirigida a um grupo de consumidores. Ela existe desde muito antes da Idade Moderna, com sua industrialização. Gomes (2003, p. 84) dá exemplo de publicidade do ano 3000 a.C. Segundo a autora, este seria o anúncio mais antigo de que se tem notícia. "Originário de Tebas, no Antigo Egito, anunciava a busca de um escravo perdido ou fugido". Isso se assemelha ao início da publicidade no Brasil, onde os primeiros anúncios também foram de escravos fugidos.

Também nas ruínas de Pompéia foram descobertos letreiros, pintados nas paredes das casas, anunciando mercadorias para vender. Ainda hoje, tais anúncios podem ser encontrados, numa visita àquelas ruínas, tal o seu grau de conservação. Outros anúncios podem ser encontrados, como os que convocam a população para o espetáculo de lutas, conforme exemplo:

As quadrilhas de gladiadores do Edil lutarão dia 31 de maio.

Haverá lutas com feras selvagens

E um toldo protetor do sol. (ibidem, p. 84)

A publicidade tem objetivos claros, como a venda de produtos, serviços ou mesmo de imagem. Quando se fala de produtos, trata-se de objetos mais ou menos duráveis, desde imóveis até alimentos. Serviços são produtos que o cidadão usa e que não the pertencem, tais como: eletricidade, transportes, telefone, tinturaria, assistência médica etc., enquanto imagem é a forma como a empresa deseja ser vista pelo consumidor, enquanto instituição, a quais características, reais ou não, ela deseja ser vinculada. Anuncia a si própria e não seus produtos, por isso tais anúncios são chamados de institucionais. Por exemplo, uma empresa que deseja ser vista como fazendo parte do grupo dos que zelam pela natureza, traz estampado em seus anúncios o selo do IBAMA e outros.

Seguiremos a categorização elaborada por Vestergaard (2000, p. 1), segundo a qual a publicidade deve ser dividida entre "publicidade de prestígio" ou institucional, a industrial ou de varejo e a que se dirige ao consumidor individual. 
A primeira, de prestígio ou institucional, como o nome já leva a pensar é a publicidade na qual a empresa tenta vender não propriamente um produto, mas um nome ou a imagem. Faz parte de uma estratégia maior de comunicação empresarial com a sociedade. Busca, por intermédio da empatia, demonstrar como é essencial, agradável ou sensível aos problemas enfrentados por seu público.

Apresenta-se como preocupada com a ecologia ou qualquer tema que esteja na moda. Não faz publicidade direta de seus produtos, mas procura aumentar seu prestígio junto à população na qual está inserida e fixar sua marca num espaço mental dos consumidores, agregando empatia.

A intenção, nesse caso, não seria, diretamente, um aumento nas vendas, mas a demarcação de terreno na memória dos potenciais consumidores. O que está em jogo aí é a criação e manutenção de uma imagem como um valor social positivo, preservação da 'face' da qual falou Goffman:

Face: é uma imagem do eu delineada por atributos socialmente aprovados (...) como um comportamento verbal, uma linha seguida pelos participantes da interação que determina a forma como lidar com o outro. Este ato constitui a imagem individual, caracterizada como sendo a imagem do 'self' (GOFFMAN,1967, p. 07).

Como as publicidades feitas pelas empresas Shell e Petrobrás, que depois de terem jogado petróleo nas águas do Alasca ou na Baía de Guanabara necessitavam melhorar sua imagem e se apresentaram como empresas preocupadas com o meio ambiente, financiando projetos de conservação e/ou reestruturação ambiental. Podem ser citadas as estratégias de instituições como o Banco do Brasil, Coca-Cola e outras, que patrocinam eventos como olimpíadas, copa do mundo, companhias de ballet, ou adotam escolas públicas e outras instituições sem fins lucrativos.

Aproveitam-se, também, datas especiais como Natal, Ano Novo, Dia dos Namorados para levar mensagens de felicidades para consumidores, a fim de estar sempre em suas memórias. Essa estratégia é uma opção significativa na publicidade de grandes empresas, já que atualmente o que se vende é a 'marca', mais do que os próprios produtos. 
O segundo tipo de publicidade, a industrial ou de varejo, é aquela cujos anúncios são destinados a especialistas, a empresas ou indústrias interessadas em serviços ou produtos mais especializados. O material adquirido é agregado à produção da própria empresa, seja ele produto ou serviço. Trata-se de uma comunicação entre parceiros com interesses semelhantes. Elas aparecem preponderantemente em publicações especializadas, dirigidas a determinados segmentos profissionais. Esse trabalho não trata desse tipo de publicidade.

Há, ainda, a publicidade dirigida aos consumidores individuais. É representada pelos outdoors espalhados pela cidade, pelos anúncios veiculados na TV, pelos anúncios publicados em revistas, jornais e panfletos de diversos tipos e são dirigidos aos mais diferentes grupos sociais. Esta anuncia produtos ou serviços específicos à disposição dos consumidores.

Os anúncios da Pfizer e da BASF analisados neste trabalho são exemplos de amálgama entre a publicidade institucional e a desse tipo. Embora a Pfizer esteja fazendo claramente a publicidade do Viagra, remédio para quem tem disfunção erétil, esta empresa opta - por motivos que serão discutidos na análise - por uma publicidade quase institucional e os anúncios da BASF, analisados neste trabalho, ao mesmo tempo em que falam de como seus produtos são "perfeitos" e "importantes", colocam seu papel de importante contribuidor para a coesão social, no caso do Brasil, e promotor do bem-estar social e da qualidade de vida, no Brasil e na Alemanha.

Embora essa divisão entre propaganda e publicidade e entre os diferentes tipos de publicidade pareça estar bem demarcada, ela não acontece de maneira tão estanque assim. Chouliaraki e Fairclough (1999, p. 11) chamam a atenção para tipos de propagandas institucionais que seguem quase todos os passos da publicidade. Carvalho, em um artigo de jornal, discorre sobre a propaganda eleitoral

..., fica a dúvida se ainda existe, como aprendemos na teoria, a tênue fronteira entre a propaganda (com fundamentos ideológicos ou políticos) e publicidade (com fundamentos individualistas e comercial). (...) A propaganda política cede espaço para a publicidade eleitoral, pois a 'escolha' de um candidato é similar à de 
um produto ou serviço: todos têm os mesmos atributos, mas marcas diferentes" (CARVALHO, 2004).

Também Fix (1997, p. 97) ${ }^{24}$, ao tratar de intertextualidade, afirma: "Trata-se aqui de textos publicitários de cunho 'político' e comercial, ..."

É desnecessário analisar aqui esse tipo de mistura que ocorre entre as duas atividades. Da mesma forma que a propaganda faz uso de elementos da publicidade, esta não deixa de veicular idéias, ideologias, valores éticos e sociais. Ambas fazem uso de argumentação persuasiva e, portanto, a delimitação clara entre as duas atividades não é possível, elas tornam-se a cada dia mais híbridas. Este trabalho reconhece a propaganda como um termo mais abrangente, podendo, portanto, ser usado nos dois sentidos. A própria lei disciplinadora da atividade publicitária (n. 4860) trata os dois termos indistintamente.

A propaganda/publicidade, como foi afirmado acima, existe há muito tempo, mas é a partir do surgimento de uma série de fatores que ela se torna mais abrangente e efetiva, como a conhecemos atualmente. A publicidade é uma das muitas práticas sociais envolvidas na construção da sociedade atual. Ela não ocorre paralelamente, mesmo porque se dirige à sociedade com o intuito de levála a uma ação/resposta. Neste caso, à aquisição do produto veiculado ou ao consumo da própria publicidade em si.

Por ser um termo que provoca muitas discussões, partiremos, primeiramente, para uma definição de sentido mais amplo:

No sentido lato, a publicidade é o emprego dos meios audio-visuais para o serviço de difusão maciça de um ideal, de um fato ou de uma solicitação. Neste sentido, ela não se limita à indústria ou ao comércio, mas tem prolongamentos tanto na vida cultural como na política (MARCUS-STEIFF, 1974, p. 64).

Como se pode perceber por essa definição, o autor não diferencia tão claramente publicidade de propaganda, nem tampouco define publicidade como sendo apenas da área do comércio e da indústria, e propaganda como um dos fatores que interferem na vida cultural e política.

24 "Gemeint sind Werbetexte politischer und kommerzieller Art..." 
Há diversas opiniões quanto à utilidade da publicidade. Algumas a consideram útil e a colocam como uma forma de veiculação de informações necessárias aos consumidores, informações que sem os anúncios publicitários jamais chegariam às pessoas interessadas em adquirir determinados produtos ou serviços, propiciando ao consumidor fazer comparações nos quesitos preços, qualidade etc. Seria, portanto, um serviço de utilidade pública.

Mas, tanto os anunciantes como os publicitários, e todos os envolvidos nessa área, têm como objetivo o lucro propiciado pela venda do produto ou serviço anunciado. Portanto, o argumento de que a publicidade é um bem para o consumidor pode ser facilmente questionado. Ainda mais quando esta se propõe não só a veicular informações sobre produtos ou serviços, mas também a uma sistemática exploração do universo dos desejos (CARVALHO, 2002) dos indivíduos aos quais são destinadas.

Pode-se perceber a semelhança entre essa idéia de uma publicidade, defendida como um serviço ao consumidor e a idéia de língua como um código transparente, a serviço da transmissão de informações, independente de imposições normativas sobre o modo de ocorrência das interações entre os indivíduos em sociedade. Continua o discurso de uma possível objetividade da informação, que desqualifica a presença de um sujeito, fruto de resultados históricos.

Em seu artigo, Quesnel (1974) faz um levantamento entre diversos autores e demonstra que as opiniões quanto ao tema são as mais diversas possíveis. $O$ próprio autor comenta que em sua primeira abordagem em relação à publicidade encarou-a como um 'sistema de comunicação' que possibilitaria o escoamento de mercadorias, fazendo a 'ponte' entre produtores e consumidores. Embora sua definição seja semelhante à definição da publicidade como de utilidade pública, chamamos atenção para o fato de o autor considerá-la um sistema de comunicação.

Posteriormente, Quesnel reconhece na publicidade além das funções econômicas de escoamento, acima citadas, funções com capacidade de estimular ou desenvolver comportamentos e que funcionam como forma de "... aculturação 
típica das sociedades economicamente desenvolvidas. Controle social de novo tipo ela se dirige ao grande público" (ibidem, p.83).

Este trabalho concorda com o autor, no que diz respeito ao fato de a publicidade ser um sistema de comunicação, assim como com o fato de ter funções de ordem cultural. Além disso, enfoca-a como um 'sistema aberto'. O que implica que ela tem muitas variáveis que a moldam, não sendo, portanto, possível de controlar todas ao mesmo tempo.

A publicidade, por razões técnicas e ideológicas, funciona como se a sociedade de massa fosse uma sociedade sem classes, já que transforma todos os indivíduos em consumidores potenciais. Primeiro, ela cria a idéia de uma aparente democracia, ou seja, todos teriam acesso a tudo, visto que tudo está à disposição de todos no mercado.

Esse processo de nivelamento não ocorre em função de extinção das diferenças de classes, mas pela padronização do que é apresentado ao público, assim como pela padronização dos gostos, levada a cabo pelos meios de comunicação de massa. Se o gosto é padronizado ele, porém, não é estático. A publicidade se encarrega de, continuamente, estabelecer novos critérios para ele, já que novos produtos devem ser criados e escoados para manter a economia se movimentando.

Segundo Horkheimer e Adorno (2000), o consumidor, adestrado pela indústria cultural, se satisfaz com a produção do 'sempre igual' e termina por não consumir o que não é adequado à imagem que se faz dos produtos. Apenas consome o que é avalizado por 'experts' (publicidade, figuras famosas ou qualquer celebridade momentânea). "A publicidade (...) tudo o que não porta o seu selo é economicamente suspeito" (ibidem, p. 209).

Para assegurar o maior lucro possível com um só produto, surgiu a chamada 'sinergia' entre produtos. Para um só tema existe uma cadeia de produtos que são lançados nos mais diversos meios, como: filme, livro, desenho na televisão, gibi, games de computador, bonecos, chaveiros, roupas etc. Constata-se a tendência de não se fazer mais livros ou filmes, mas uma série de produtos encadeados, cada um facilitando e estimulando a possibilidade de 
colocação do outro no mercado. Tudo, é claro, avalizado pela publicidade e pelas opiniões de 'experts'. Para todos, algo é pensado de forma que não se perca nenhum consumidor, que nenhuma dimensão da vida do indivíduo escape ao mercantilismo e que as aparentes diferenças entre os consumidores já venham marcadas, previstas e difundidas artificialmente.

Os autores também afirmam que: "a repetição cega e a rápida expansão de palavras estabelecidas une a publicidade à palavra de ordem totalitária" (ibidem, p. 212). Essa é uma das explicações para o fato de tantas invenções na linguagem publicitária em quase todos os campos, e em algumas áreas bem mais do que outras, como no caso da área da indústria de cosméticos. As pessoas ficam repetindo como se fossem invenções tecnológicas importantíssimas, quando na verdade não têm tão clara a idéia do que significam essas palavras.

Fairclough (2001) chama esse processo de criação de palavras de 'atualização de vocabulário', relexicalização ou 'tecnologização da linguagem'. Para mostrar que se está a par do progresso, da evolução da ciência, que não se está defasado quanto aos novos conceitos que entram no mercado profissional. Continuamente, tem-se a necessidade de atualizar o vocabulário, de renomear realidades, que passam, então, a ser repetidas ad nauseam. Um exemplo disso na indústria de cosmético é a palavra "babosa", usada em xampus, que virou "Aloe vera", seu nome científico e - provavelmente, de acordo com 'pesquisas' de mercado - muito mais "atraente" aos consumidores que identificam o aval da ciência.

Há uma substituição de palavras antigas, comprometidas com outras realidades, por palavras novas, com valores novos, sem conotações negativas anteriores, que demonstram relações de poder, que fogem ao controle dos interessados em escondê-las. As pessoas são instadas a uma atualização de seu linguajar de modo a se mostrar sempre bem informadas com a evolução da sociedade. E como já disse Maturana (2002), um novo linguajar significa um novo posicionamento na forma de agir. 
Essa atualização é um tipo de capital que pode render dividendos como um melhor emprego ou salário, um tipo de pedágio que deve ser pago de forma a se parecer sempre atualizado.

Para o produtor/comerciante, não importa de onde virá o dinheiro para comprar suas mercadorias, importa apenas que elas sejam vendidas. Após ter nivelado todos os consumidores, paradoxalmente, segrega-os, pois nem todos têm o mesmo poder aquisitivo. Esse "grande público", ou sociedade de massa, é classificada, de acordo com técnicas de pesquisa de consumo, em grupos diferenciados. Já se sabe que nem todos os produtos são oferecidos a todos da mesma maneira. Existem publicidades que dependem de faixa etária, poder aquisitivo, classe profissional e até etnia e crença. Exemplos recentes, no Brasil, são os cosméticos especiais anunciados em revistas direcionadas ao público negro, ou produtos religiosos oferecidos ao público evangélico em suas rádios e programas de televisão.

Como dizem Horkheimer e Adorno (2002), o público alvo está dividido em grupos de poder aquisitivo, que não passam de "estatísticas coloridas" penduradas nas paredes dos escritórios de publicidade e que no dia-a-dia se traduzem nos objetos que os consumidores conseguem ostentar, clara ou veladamente.

Quando Quesnel (ibid.) fala da publicidade como um 'modo de aculturação típico da sociedade', chama a atenção para a onipresença da publicidade, que cria um novo sistema de valores e desempenha um papel pedagógico através de sua 'inculcação' na cabeça dos consumidores.

Não que isso seja uma prerrogativa da publicidade. Da mesma forma que a arte grega caracterizava um 'modelo de civilização', a comunicação em massa - e, dentro dela, a publicidade, talvez sua expressão maior - caracteriza o atual modelo de civilização de boa parte do planeta. Dentro dessa 'previsão', as diferenças tão propaladas como opções de escolha dos consumidores passam a ter significados outros que o valor de uso do que é comprado. Fato para o qual chamam a atenção diversos autores. 
Os produtos da indústria de propagandas são produtos semióticos. Ao consumir bens, estamos satisfazendo, ao mesmo tempo, necessidades materiais e sociais. Os objetos que usamos e consumimos deixam de ser meros objetos de uso para se tornarem veículos de informação sobre o tipo de pessoa que somos, ou gostaríamos de ser.

Barthes (2003), Baudrillard (2003) e outros já afirmam que os objetos são 'semantizados'. Eles são produtos que já não são comprados pelo seu valor de uso, mas pelo tipo de status que fornecem a quem tem o poder para adquiri-los. São signos de algo, não representam mais o próprio produto e sua utilidade. Passam a ser "... um sistema semiológico segundo" (itálico do autor) (BARTHES, 2003 p. 205). E, um 'sistema semiológico segundo' que escolhe apenas as características desejadas para vincular ao signo, no caso, o produto. Por isso o cuidado na criação do inventário perceptual. É esse inventário que dará ao produto/produtores uma identidade com a qual se fixar no espaço mental do consumidor, fornecendo a este último também uma identidade.

A publicidade também se torna o próprio produto a ser vendido, consumido. Não é necessário saber se o indivíduo compra ou não o produto anunciado, mas que ele consome o próprio anúncio, o 'ambiente' cultural veiculado pelos anúncios, daí, atualmente, esta também ser encarada como tendo uma função pedagógica de aculturação. É interessante perceber como a onipresença da publicidade instaura o indivíduo como sujeito, identidade, ser, dentro de um tempo. As mensagens da publicidade são massificadoras, pois sua repetição é contínua, assim seus temas básicos, que variam apenas nos motivos com que são veiculados.

Todo sistema necessita de um esquema de auto-reprodução para poder manter-se em funcionamento. A preocupação é fazer com que todos os integrantes que compõem esse regime assumam comportamentos que mantenham as coisas funcionando da forma desejada para sua manutenção/reprodução. Para isso é necessária a manifestação do esquema de auto-reprodução que assume “... a forma de normas, hábitos, leis, redes de regulamentação etc. que garantam a unidade do processo, isto é, a consistência 
apropriada entre comportamentos individuais e o esquema de reprodução" (HARVEY, 2004, p. 117). A publicidade é, atualmente, uma das maiores responsáveis pela auto-reprodução da civilização industrial numa sociedade de consumo.

O tema 'auto-desenvolvimento' é discutido por Bucci; Kehl (2004, p. 22), quando estes autores falam a respeito do 'poder midiático' a que a publicidade pertence e afirmam ser esse poder uma "instância autônoma de decisões" que permite sua reprodução automática, na qual os indivíduos são "sujeitos inconscientes do capital".

Em todo caso, a sociedade industrial e de consumo, como a conhecemos hoje, seria impossível de existir sem a publicidade, já que esta se instala com funções pedagógicas, culturais, condicionadoras, que permitem a auto-reprodução do modelo econômico no qual vive grande parte da humanidade.

Alguns autores defendem que nem a publicidade é um 'bezerro de ouro', como é encarada muitas vezes pelos publicitários, nem tampouco um 'bode expiatório' como é tida por alguns intelectuais. Dentro dessa articulação social estão surgindo grupos civis e institucionais dispostos a questionar a hegemonia da publicidade, propondo formas para que a sociedade se defenda, formas ainda um tanto difícil de serem construídas, tendo em vista esse 'poder midiático' autoreprodutivo.

Essas novas formas surgem como contra-campanhas publicitárias destinadas a orientar a opinião pública segundo o interesse geral. Podemos ver algumas dessas tentativas levadas a cabo em áreas como a do consumo de tabaco, que tem nos ministérios da saúde seu grande inimigo e financiador de contra-propagandas. Isto ocorre porque o gasto com doenças provocadas pelo consumo do fumo é tão grande que o ministério e alguns grupos resolveram intervir.

Mesmo assim, se formos analisar melhor esse tipo de contra-campanha, percebemos que ao utilizar o slogan 'Fumar é prejudicial à saúde', a argumentação do anúncio opta por penalizar o ato de fumar, que é uma atividade feita pela vítima. Percebe-se que o Ministério da Saúde, mesmo engajando-se na 
contra-campanha não se encontra exatamente no lado oposto ao dos produtores. Outras tentativas vêm sendo feitas por educadores e pesquisadores que, entre outras atividades, buscam levar para a sala de aula análises de publicidade, com o intuito de provocar nos alunos uma maior criticidade e tirá-los da posição de 'presa fácil' do poder de sedução da publicidade.

De qualquer forma, os exemplos discutidos anteriomente servem para demonstrar momentos em que se pode perceber que a articulação entre as práticas sociais permite a emergência de fenômenos nem sempre previsíveis.

\subsection{Estrutura e linguagem do anúncio de publicidade}

Para a apresentação dos produtos ou serviços a serem oferecidos para o consumo, foram desenvolvidas estratégias elaboradas pela psicagogia, vocábulo que tem sua origem na língua grega e que, segundo Michaelis (1998), significa "evocação mágica das almas, a arte de guiar as almas pelo 'melhor' caminho", ou seja, recursos discursivos que visam à adesão dos espíritos,

Uma dessas primeiras estratégias foi a AIDA: Attention, Interest, Desire, Action:

Atenção: chamar a atenção, títulos, foto, slogans. Na verdade, chega-se à conclusão de que qualquer maneira de chamar a atenção do cliente é válida. Seja fazendo o que se espera, seja quebrando a expectativa;

$>$ Interesse: despertar interesse, (geralmente contendo palavras com valores meliorativos e hiperbólicos, tentando ir ao encontro das expectativas do leitor);

$>$ Desejo: estimular o desejo

$>$ Ação: induzir à ação

Segundo Vestergaard; Schroeder (2000:, p. 47) outros autores colocam, entre os estágios Desejo e Ação, o estágio da Convicção. Lembrando que todos os estágios trabalham em função da última etapa, a Ação: compra, aquisição ou lembrança da marca. 
E a partir dessa primeira estratégia, surgem especializações como a apresentada no livro de Janich (1999), que comenta o diagrama de Schweiger; Schrattenecker, sempre considerando uma forma de 'acorrentar' o consumidor às suas mensagens. $O$ interessante dessa estratégia é que o consumidor parece sempre pronto para 'abandonar' o produto/produtor. Estes devem estar sempre atentos para prendê-lo com suas campanhas publicitárias. Essa é, provavelmente, uma das explicações para a quantidade de dinheiro movimentada pela indústria da publicidade. Ela própria se encarrega de colocar-se como essencial no jogo do escoamento de mercadoria. Essa estratégia parte do princípio de que o consumidor é muito menos passivo que o da estratégia anterior.

\begin{tabular}{|l|l|l|}
\hline Nível de atuação & Critério de atuação & Fórmula \\
\hline Situação inicial & $\begin{array}{l}\text { Características sócio-demográficas } \\
\text { e motivos do indivíduo alvo, } \\
\text { satisfação através do produto à } \\
\text { disposição }\end{array}$ & \\
\hline Nível de ação & Atenção e interesse & Emitido não significa recebido \\
\hline idem & $\begin{array}{l}\text { Compreensão da mensagem } \\
\text { (assimilação do enunciado, } \\
\text { reconhecimento da marca etc.) }\end{array}$ & $\begin{array}{l}\text { Recebido não } \\
\text { compreendido }\end{array}$ \\
\hline idem & $\begin{array}{l}\text { Atitude, imagem, intenção de } \\
\text { compra }\end{array}$ & $\begin{array}{l}\text { Compreendido não significa } \\
\text { concordância }\end{array}$ \\
\hline idem & Ação (para a compra) & Concordância não significa ação \\
\hline idem & Repetição da ação (nova compra) & Ação não significa repetição \\
\hline
\end{tabular}

(Schweiger; Schrattenecker, apud JANICH, 1999, p. 20) ${ }^{25}$

\begin{tabular}{|c|c|c|}
\hline Wirkungsstufe & Kriterium der Werbewirkung & Merkspruch \\
\hline 0. Ausgangslage & $\begin{array}{l}\text { Soziodemografische Merkmale und } \\
\text { Motive der Zielpersonen, Befriedigung } \\
\text { durch die vorhandenen Produkte }\end{array}$ & \\
\hline 1.Wirkungsstufe & Aufmerksamkeit und Wahrnehmung & $\begin{array}{l}\text { Gesendet heisst noch lange nicht } \\
\text { empfangen! }\end{array}$ \\
\hline idem & $\begin{array}{l}\text { Verstehen der Werbebotschaft (also } \\
\text { Verarbeiten der Werbeaussage, } \\
\text { Markenkenntniss, usw }\end{array}$ & $\begin{array}{l}\text { Empfangen heisst noch lange nicht } \\
\text { verstanden! }\end{array}$ \\
\hline idem & Einstellung, Image, Kaufabsicht & $\begin{array}{l}\text { Verstanden heisst noch lange nicht } \\
\text { einverstanden! }\end{array}$ \\
\hline idem & Handlung (z.B. Kauf (...)) & $\begin{array}{l}\text { Einverstanden heisst noch lange nicht } \\
\text { getan! }\end{array}$ \\
\hline
\end{tabular}


Como tudo deve ocorrer em poucos segundos, foi desenvolvida a PUV Proposta Única de Venda -, uma proposta que diferencie determinado produto de outros, o que, atualmente, não deixa de ser difícil, pois dificilmente um produto é tão inovador assim ou tem uma qualidade muito diferente da de seus similares. Prefere-se, portanto, o uso de pessoas famosas anunciando, ou argüindo que tal produto tem menor preço ou qualidade superior.

Posteriormente à estratégia AIDA, surge MR (motivation research). Quase nada é feito nas empresas de publicidade que não lance mão dessas pesquisas sobre a motivação, que transforma o consumidor 'em pontos coloridos nas paredes dos laboratórios'. Nela entra todo e qualquer campo de pesquisa que possa levar a abocanhar o consumidor. Como: psicagogia, psicologia, sociologia, estatística, marketing, fisiologia, economia e também artes gráficas, poesia, etc. Eis aí uma verdadeira pesquisa multidisciplinar.

As pesquisas motivacionais surgiram, entre outros fatores, para livrar os produtores da crise de superprodução e também pelo fato de se colocarem no mercado produtos cada vez mais semelhantes entre si. É importante uma pesquisa com grupos representativos de indivíduos, na qual se vasculha cada rincão dos desejos, medos, emoções, hábitos. A partir desses dados, podem-se produzir campanhas para esses grupos de pessoas semelhantes, que mostrem 0 quanto elas são diferentes, por usarem esse produto feito em série dentro de suas indústrias.

Um produto, hoje, com bastante semelhança entre suas unidades, são os automóveis. Os carros têm quase o mesmo design, as normas de segurança, características visuais, mecânicas etc. No entanto, seus anúncios tentam "vendêlos" como se cada um fosse o único, o melhor. Isso ocorre com a maioria dos produtos.

\begin{tabular}{|l|l|l|l|}
\hline idem & $\begin{array}{l}\text { Handlungswiederholung (Wiederkauf) } \\
(\ldots)\end{array}$ & $\begin{array}{l}\text { Getan heisst noch lange nicht } \\
\text { dabeigeblieben! }\end{array}$ \\
\hline
\end{tabular}


A montagem 'clássica', mas não obrigatória (SPANG, 1987), pode ser assim definida:

\section{Inventio}

A inventio do sistema aristotélico, no caso da publicidade, já é conhecida, pois o anunciante determina sobre o que se vai falar. Continua, porém, a inventio a respeito de que idéias, que material verbal, visual e auditivo utilizar para a veiculação adequada do tema, tendo em mente para que público se destina o anúncio. Levando em consideração que a publicidade é uma bricolagem, tudo é possível, desde que o consumidor seja positivamente atraído.

Captar e manter a atenção - (os itens A e I da estratégia AIDA) o excesso de anúncios espalhados por todos os lugares contribui exuberantemente para a poluição visual e a publicidade não abre mão desse recurso. Manter a atenção de um possível consumidor exige muita criatividade, que vai desde o grotesco até 0 sublime. Apenas a aceitação do público ou não fornece esse limite.

A apresentação - As estratégias propostas por Aristóteles, mesmo depois de dois mil e quinhentos anos, ainda persistem no esquema atual da publicidade, com possibilidades de variações ou omissões. Não esquecendo que, nas publicidades atuais, os elementos visuais são, não raras vezes, mais importantes que os elementos lingüísticos, por terem um efeito muito mais rápido no leitor.

Segundo Zielke (1991), apenas 5\% dos leitores lêem o corpo do texto de um anúncio publicitário. O texto vale mais como um item gráfico, compacto, que funciona como um índice de idoneidade e dá respeitabilidade ao anúncio. O leitor pode entender que se há um texto, é porque o anunciante tem algo de sério e importante a falar. A imagem auxilia, orienta na direção de como o texto deve ser interpretado, principalmente em nossa sociedade onde predomina o visual.

\section{Dispositio:}

A - O título corresponde, no esquema aristotélico, ao exórdium, à proposição do tema. Neste esquema, tenta-se exprimir logo de entrada sobre 0 que se quer falar. Em publicidade é mais importante travar contato e conseguir ganhar a atenção do possível leitor do que se limitar ao conteúdo. Não importa muito que o título traga o resumo do que o texto tratará. Muitas vezes o título traz 
uma vagueza intencional, sem referentes identificáveis, e o que desperta no leitor o desejo de ler o anúncio é, justamente, essa vagueza. Segundo Reboul (1975), o título é lido 5 vezes mais que o anúncio inteiro e, segundo Zielke (1991), apenas $5 \%$ dos leitores lêem o texto todo.

B - Narratio, que no esquema tradicional é dividido em Enumeratio e Argumentatio podem ser reunidos, tendo em vista o pouco espaço e tempo à disposição. Na maioria das vezes, tende a ser uma paráfrase da imagem e funciona, também, graficamente como um ícone de algo que deve ser importante. A sua simples presença fornece idoneidade ao anúncio, tendo, portanto, um efeito indireto. Também funciona de forma a delimitar o excesso de polissemia que uma imagem pode apresentar e ao mesmo tempo tenta conduzir a determinadas interpretações, como que completando sentidos que faltam na imagem (KRESS; van LEEUWEN, 2001).

Como já foi afirmado, o texto publicitário é um texto multimodal. As organizações lingüísticas e visuais ocorrem conjuntamente no anúncio, e por intermédio desse cruzamento, provoca-se o surgimento de um somatório de novas informações, além das que sozinhos comportam. As construções de sentidos não existem a priori, mas apenas por intermédio do jogo interpretativo, da negociação concomitante entre os sistemas semióticos envolvidos, assim como entre os participantes.

D - Peroratio, o epílogo. Nas publicidades atuais, propõe clara ou veladamente a intenção do anúncio. É um resumo mais compreensível e fácil de memorizar, como no anúncio da BASF brasileira: "Essa é a nossa química", que Zielke (1991, p. 84) opta por chamar de 'claim', pois ainda não é o slogan. Este também faz parte do peroratio: "Abuse e Use C\&A". É o arremate, o fechamento da argumentação. A BASF alemã apresenta o slogan: "The chemical company'. A BASF brasileira apresenta ainda o slogan expandido, o 'claim': "A química da vida. The chemical company". Há também o logotipo finalizando o anúncio. Ele funciona como uma retomada da voz que foi delegada à agência publicitária. O logotipo é a assinatura do anunciante, avalizando o que foi dito a seu respeito. 
E - Actio et pronuntiatio - No caso de anúncios, tudo o que tem a ver com a concretização de sua apresentação. Em anúncios estáticos, como em revistas: além do material lingüístico em si, o local de sua inserção, composição de cores, imagens, tons, formas, os personagens usados, aspectos tipográficos, disposição visual etc.

Todos esses passos não ocorrem de maneira estanque, da forma como estão apresentados acima. Eles ocorrem ao mesmo tempo. As idéias, os temas, as imagens escolhidas para veicular a narrativa, assim como a disposição das mesmas em transcrições textuais e suas formas gramaticais, já trazem consigo informações secundárias sobre que tipo de mensagem e de identidade 0 anunciante deseja passar para si e para o seu interlocutor, ou mesmo deixa passar a sua revelia para o leitor do anúncio, que vai "lendo" todos esses dados e com eles interagindo, consciente ou inconscientemente, também, afetivamente.

Discutindo a última etapa da AIDA, a ação/compra/lembrança da marca, pode-se perceber que a incitação a ela ocorre indiretamente. A publicidade deve evitar agredir o consumidor e reforçar seu caráter persuasivo. Alguns dos 20 verbos mais freqüentes, em 139 dos 179 casos pesquisados por Vestergaard; Schroeder (2000, p. 68), são os seguintes: "experimente, peça, adquira, tome, deixe, solicite, use, chame, faça, corra, venha, seja" etc. Por isso prefere-se 'abuse e use', 'agende uma hora conosco'.

O motivo para não usar o verbo 'comprar' é a sensação que ele provoca nos indivíduos. Ao 'comprar' deve-se dar algo em troca pelo objeto adquirido e nesse caso seria desencadeado o sentimento de perda, seja lá o que for que se está dando. Outros verbos utilizados provocariam no consumidor a sensação de ganho ou de lucro.

Para se conseguir tudo o que foi descrito acima, é necessária uma linguagem apropriada. Com isso não se afirma que exista 'uma linguagem' para a publicidade e outra para outros campos. A Língua, como foi dito antes, comporta em si infinitas possibilidades dentro das atividades humanas. As palavras são todas feitas de seqüências de sons, ou seja, são feitas do mesmo material, seja este sonoro ou visual. Isso faz com que julguemos as palavras semelhantes e 
uniformes e sempre destinadas ao mesmo uso. Essa uniformidade nos impede de perceber a diversidade de usos em que ocorrem (WITTGENSTEIN, 1984).

Spang (1987) levanta 4 características principais para a linguagem da publicidade.

- Eficácia - é sua característica principal e em torno desse propósito giram as outras três;

- Concisão - pelos motivos já elencados, há preferência por frases curtas, com elipses e uso abundante de pontos finais, pois estes indicam que foi finalizada uma unidade de informação e, portanto, de compreensão mais rápida.

- Liberdade - entendida como fantasia quase ilimitada, sem que a compreensão e aceitabilidade da informação sejam prejudicadas. Ao analisarmos qualquer peça publicitária, não é difícil perceber que o Aptum, isto é, o conhecimento lingüístico e das regras do 'bem falar' pode ser quebrado, a fim de se jogar com o humor, de criar impacto, estranheza, de inventar palavras que só podem ser entendidas no contexto e, com isso, criar formas de angariar a atenção e empatia do consumidor. A publicidade usa todos esses recursos com muita competência.

- Imediatismo - tendência a uso de verbos no indicativo-presente, futuro, infinitivo e imperativo; nominalizações, cujo processo de compreensão, embora se faça em detrimento do apagamento de agentes e características verbais, ocorre mais rapidamente. Imagens são sempre mais diretas do que textos.

Na publicidade é imprescindível o uso de topoi ou tópicos que Perelman; Olbrecht-Tyteca (2002, p. 95) definem como tópicos de lugares-comuns e que funcionam como "um arsenal indispensável, do qual, de um modo ou de outro, quem quer persuadir outrem deverá lançar mão". Um depósito de argumentos a serem usados para montar, enriquecer o raciocínio.

$\mathrm{Na}$ publicidade, por exemplo, prefere-se usar o lugar de qualidade ao de quantidade, pois ninguém gosta de se identificar com a massa. Todo o trabalho da publicidade é justamente tentar convencer o consumidor de sua individualidade, 
de sua melhor posição perante outrem. O uso de fraseologismos é acentuado, estes são grupos de palavras ou frases que se unem de maneira mais ou menos fixa. Fraseologismo será uma de nossas categorias de análise e, portanto, será discutido no capítulo 5 .

O slogan, termo de origem escocesa, merece algumas linhas. (REBOUL, 1975). Era o grito de guerra do clã. O nome do mesmo tipo de grito de guerra dado por tribos francesas era réclaim. Tinha que ser curto e forte para dar coragem e incitar para a guerra. Não deveria deixar margem para elucubrações: se a guerra era justa ou não, se valia a pena ou não etc. 'Morrer por Danzig', na Alemanha durante a Segunda Guerra, ou "Integrar para não entregar", quando da construção da estrada Transamazônica na década de 70, são bons exemplos.

Um bom slogan só deixa espaço para a reverberação. É uma fórmula de comunicação fechada em si mesma, feito um oroboro. Pode ser sinônimo de clichê, palavra de ordem, lema. O slogan atual continua com a mesma proposta. Não é feito para levar a pensar, é feito para levar a agir, lembrar-se da marca. É um tipo de frase curta, que mais chama a atenção "pelo que não diz" do que pelo que afirma. Afirma algo que se pressupõe verídico, embora não seja consciente, nem claro. É bem adequado à dicotomia na qual o ser humano vive com prazer: 'O que não é preto é branco', 'o que não está perdido está ganho'.

O slogan faz parte dessa lógica binária, na qual o maniqueísmo é estabelecido com dois valores mutuamente excludentes, sem possibilidade de gradações. Como no excelente slogan: "Se é Bayer é bom", portanto, se não é Bayer, não é bom. Ou no caso do exemplo da BASF: "A química da vida", subentende-se que as outras não são a química da vida, já que, nesse caso, o uso do artigo definido funciona como definição de característica simplificadora, essencial para determinação de uma classe (POLENZ, 1985, p.149). Se fosse 'uma química da vida' poderia implicar a existência de outras. Esse mecanismo funciona a contento para criação de estereótipos, como por exemplo: "o nordestino é...; o alemão é...".

O slogan é um 'grito parado no ar', anônimo. Fica-se repetindo o que se ouve, sem saber de onde se originam essas formas de pensar, nem a quem são 
dirigidas. Quando se pensa por slogans, deixa-se levar por pensamentos apenas repetidos sem que haja qualquer tipo de reflexão sobre eles. Nesse campo, o slogan dificilmente pode ser separado da ideologia, pois provoca o mesmo resultado, "o de congelar o pensamento" (REBOUL, 1975). Funciona como um eco, que fica ressoando, incitando à lembrança.

Como a publicidade é direcionada ao ouvinte/leitor, ela deve ser percebida em segundos, para o leitor não passar adiante. Existem infinitos detalhes a serem percebidos em nosso meio ambiente, elementos com os quais os indivíduos interagem, conscientemente ou não, tornando impossível sua concentração sobre todos ao mesmo tempo. A percepção é, portanto, sempre fragmentária (VESTER, 1986). Por esse motivo, a necessidade do apelo emocional que se faz ao consumidor.

Retornando ao anúncio como um todo, a concisão tem a ver com o espaço, com a rapidez com que deve ser percebido e com a exploração das motivações básicas aventadas por Brown (1971): prestígio, segurança, felicidade, liberdade, coragem etc. $\mathrm{O}$ que importa é como o produto será ancorado afetivamente à situação criada. Será a prescrição sintética do que devemos desejar ou não, compreender, temer etc. Para que isso ocorra de forma eficiente, a escolha dos elementos que compõem os anúncios não pode ser arbitrária.

Brown (1971) esquematiza alguns meios usados para melhor atingir o interlocutor. Esses critérios não são específicos para a publicidade, mas com certeza podem ser usados como elementos de análise da publicidade. Segundo ele, a maioria dos seres humanos prefere que os problemas sejam simples e não complexos - reflexo da lógica binária - e, portanto, prefere vê-los apresentados dessa forma. Essa maioria também prefere não ver seus preconceitos desmascarados. A percepção de que o preconceito era improcedente pode provocar insegurança, medo, raiva, vergonha... O indivíduo "deseja sentir que pertence a alguém ou a alguma coisa" (ibidem, p. 27). Isso leva, automaticamente, ao fato de que se alguém pertence a um grupo, outrem teve que ficar de fora.

Isso exposto, o autor levanta uma série recorrente de mecanismos, de que o propagandista vai fazer uso em sua linguagem sedutora: 
- uso de estereótipos: por intermédio de fórmulas já consagradas, tanto nos códigos visuais, como no lingüístico, isso funciona como argumentos de autoridade, além de possibilitar a concisão e imediatismo, por isso o uso de lugares-comuns, fraseologismos que rapidamente acionam scripts com os quais o público alvo está familiarizado.

- substituição de nomes: como foi dito acima a escolha é cuidadosa, procuram-se termos meliorativos que possam influenciar positivamente.

- seleção: escolha dos fatos ou recortes específicos que possam conduzir a uma conclusão desejada e ao apagamento de outros;

- 'ordenação das verdades' em grande escala, com uma cuidadosa seleção de narrativas, com heróis e heroínas impecáveis;

- afirmação e repetição: pela reiteração se objetiva minar uma possível contradição do consumidor. Para isso são usadas frases no imperativo afirmativo, repetição das palavras, dos temas e das formas;

- criação de adversários: provoca a união de grupos contra outros; no caso da publicidade de cosméticos, o inimigo são as rugas, o envelhecimento, a sensação de abandono por envelhecer, a velhice como o não belo etc. Em detergente, é a mitologia da pureza obsessiva, elegendo como inimigos a sujeira, os germes, a doença, etc. Criam-se bodes expiatórios, culpados por tudo que deveria nos angustiar, de acordo com a publicidade.

O compromisso da publicidade é com a lembrança da marca e/ou venda dos produtos que anuncia e, embora siga boa parte das regras estabelecidas por Aristóteles e outros, faz uma retomada desses passos de acordo com suas necessidades. Se para alcançar seu objetivo, isto é, chamar atenção, ela tem que subverter determinadas regras, sejam quais forem estas, não haverá problema. Tudo é permitido desde que seja compreensível e bem sucedida em seu propósito. Chama a atenção, porém, saber que o esqueleto de regras esboçadas há mais de 2500 anos continua sendo válido até hoje e que existe realmente uma forma básica de organizar o pensamento e expô-lo de acordo com determinadas regras, que vêm sendo mantidas. 
Fica clara a existência de uma prática social que se expressa em determinados tipos de interações sociais, que vem sendo reproduzida e exercida há milênios, dentro de instituições sociais como: escolas gregas, romanas, mosteiros e faculdades de Direito, de Publicidade e de Marketing etc. Estas práticas sociais se encarregam de organizar, controlar e realimentar o seu próprio uso, sendo dinâmicas o suficiente para poderem se readaptar de acordo com as necessidades histórico-sociais.

O conhecimento dessas regras permite que determinados grupos que a elas tenham acesso, tenham o direito à voz e, portanto, o direito de serem ouvidos e de construir os sentidos desejados, dentro do espaço público encarregado da eterna reconstrução da sociedade (BOURDIEU, 1992). Um dos espaços privilegiados da atualidade para a construção social tem como um de seus expoentes justamente o sistema publicitário, um espaço que prima pela palavra autoritária e ao mesmo tempo sedutora e invasiva em quase todos os espaços da vida humana.

\subsection{Cultura e comunicação de massas}

\section{GERALDÃO - Glauco}

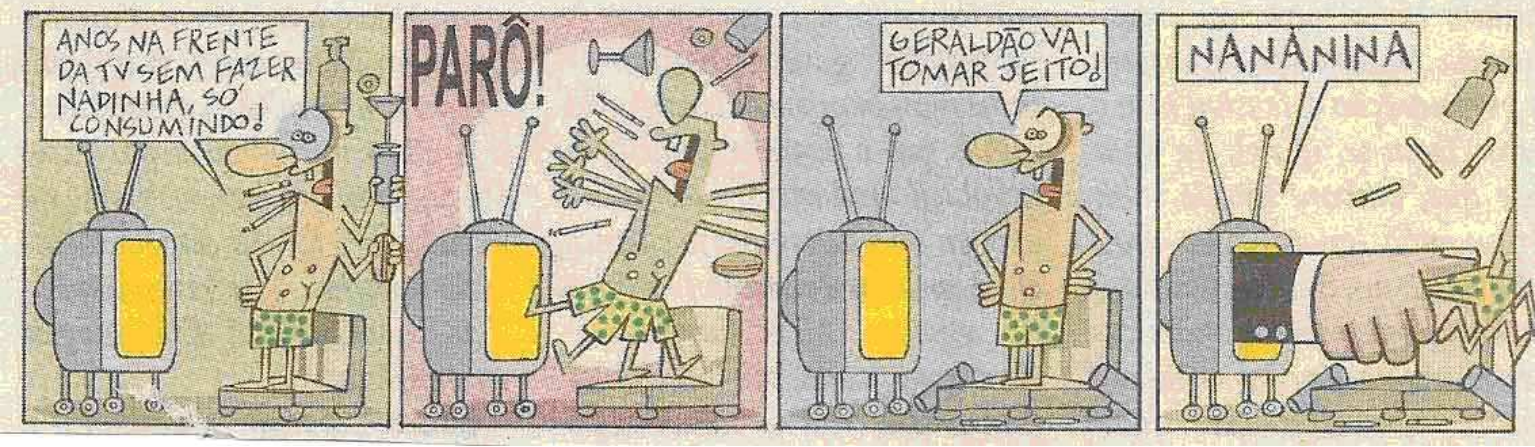

(Folha de São Paulo,29. nov, 2004)

O discurso da publicidade é considerado um discurso público, pois se dirige a uma massa de indivíduos, por intermédio de comunicação de massas. Não se 
deve incorrer no erro de confundir comunicação de massa com os veículos de divulgação, como jornais, televisão, revistas etc. Estes são os instrumentos por intermédio dos quais ela ocorre.

Consideramos 'massa', dentro dessa junção com o termo comunicação, como um conjunto anônimo de indivíduos dos mais diversos estratos sociais e a comunicação de massa como um tipo de comunicação que envolve esse tipo de público, a forma de comunicação e o comunicador. Essa comunicação "é dirigida a uma audiência heterogênea e anônima; é pública, rápida e transitória" (MONNERAT, 2003, p.11). A publicidade seria uma das mais fortes interfaces desse tipo de comunicação.

No processo de industrialização que se estabeleceu com a tecnologia para a produção de bens ou serviços a serem vendidos, os produtos passaram a ser produzidos aos milhares, todos iguais e dirigidos a uma massa de compradores em potencial. Estes são divididos pelos produtores por qualidade de poder aquisitivo, além de outras categorias, como idade, religião, etnia etc., como já foi discutido.

Tornou-se necessária a criação de uma cultura que estimule e satisfaça essa variedade de grupos de indivíduos, ou seja, uma cultura que satisfaça a média do gosto dessas pessoas, tanto para as que estão em condições reais de consumir, quanto para as que se encontram às margens desse processo de consumo, mas que conseguem consumir o que é veiculado em meios de comunicação mais abrangentes, como rádio e televisão. Para isso, é necessária uma cultura que identifique qual é o gosto 'médio' dessa grande quantidade de indivíduos, e os torne consumidores desses objetos produzidos em série pelas indústrias tanto de bens e serviços como de entretenimento.

A cultura de massa realça, por meio de processos de vulgarização e espetacularização o que esse grande público tem de comum entre si. Esse 'denominador comum' entre os indivíduos será estimulado através da "simplificação, modernização, maniqueização, atualização" (MORIN, 1997, p. 54) dos temas, acontecimentos ou objetos apresentados ao público. No processo de 'atualização' de um tema ou objeto, o que ocorreu antigamente ou em outra parte 
do mundo é visto com olhar do indivíduo atual, a partir de valores referenciais de seu grupo.

Exemplos deste tipo de estratégia, são os filmes sobre antigos romances ou personagens históricos. Estes personagens são construídos de forma a se confundir, na cabeça dos espectadores, com as atrizes e atores que os representam. No processo de 'modernização', o que ocorreu 'lá' é colocado no aqui e agora com roupagem local e moderna e, portanto, de mais fácil compreensão pelo indivíduo com 'simplificações maniqueístas' do tipo 'o bem' se opondo ao ' mal', 'o certo' versus 'o errado' etc. O que era 'complicado' vira 'palatável' ao gosto nivelado do grande público. Daí a freqüência com que se mutilam acontecimentos cheios de implicações.

Esse processo vai ao encontro da forma de compreensão da maioria dos seres humanos, dentro de uma lógica binária citada anteriormente, fazendo com que o "homem médio" de que fala Morin seja criado e cultivado, para que consuma o que se produz para ele. Segundo esse autor, tudo que é recorrente e provoca uma expectativa de regularidade é passível de ser padronizado, portanto, pode ser alvo de alguma fórmula esquematizada. O esquema retórico de Aristóteles é uma prova disso. Também o é a cognição humana ao trabalhar com scripts.

No caso da cultura de massa essa esquematização é levada a cabo por intermédio dos quatro passos estipulados acima. Para que essa esquematização seja levada a contento, há a necessidade da apresentação de uma temática que seja reconhecida pelo grande público, por isso as mesmas histórias são reapresentadas com algumas variações de personagens tanto na publicidade quanto no cinema, na televisão etc. Além disso, no caso de cultura de massa, para essas criações culturais, existe implícito um certo prazo de validade da mesma forma que se impõem prazos de validade para os objetos produzidos em massa pelas indústrias.

No que se refere à discussão a respeito do conceito de cultura, os estudiosos que trabalham com aspectos culturais sabem que existe uma grande gama de definições que servem de fundamentos teóricos para as pesquisas. Gostaríamos de citar Wendt (1993, p. 116) ${ }^{3}$ : "Me recuso a destrinchar o conceito 
de "cultura" em razão das, aproximadamente, 300 definições para "culture" que Kroeber/Kluckhohn já levantaram em 1954, e das inumeráveis outras que ainda foram acrescentadas".

Por ser esse um trabalho que estuda a linguagem, busca-se uma definição que a considera como uma das práticas sociais constitutivas dos aspectos culturais, já que não se entende como possível a transmissão da cultura em um vácuo discursivo.

Concordamos com a definição de Carvalho (2003, p. 96) sobre cultura: "um sistema de agir e interagir, um sistema de crenças, valores de organização artística, científica e educacional, social e política, bem como de atividades econômicas" que servem de orientação para um grupo social.

Esse sistema de crenças, valores, costumes é transmitido por intermédio das mais diversas formas de linguagem, pois o surgimento da língua, além de outras capacidades de semiotização e seu uso como possibilidade de intermediação na interação com o outro e com o meio ambiente, é determinante para a constituição de um ser histórico e cultural.

Não há como falar de cultura de massa sem falar de sua forma de escoamento, assim como não é possível falar em alcançar essa audiência heterogênea e anônima, pública, de maneira rápida e transitória sem falar dos meios de comunicação de massa.

Os surgimentos desses meios - jornais, livros impressos em série - vão ao encontro da necessidade de expressão de uma classe em ascensão, a burguesia, que vinha se formando desde o Renascimento. O comportamento burguês e seus modos de atuação na sociedade, o comércio, a criação de capital, seu reinvestimento, começam a criar, nessa época, suas raízes. Afirma-se com toda força a partir do século XVII em diante, com as descobertas tanto de novos continentes (séc. $\mathrm{XV}, \mathrm{XVI}$ ), como de novas tecnologias, que permitem, a partir de então, seu desenvolvimento ininterrupto (HUBERMAN, 1978).

Além dos dicionários feitos nessa época, outra forma de buscar reconhecimento e aceitação e, através disso, obter poder de interferir em decisões que Ihes diziam respeito enquanto classe, surgiu com a criação de jornais diários. 
Estes, por volta de 1830, começaram a ter grande tiragem e, portanto, a ter capacidade para alcançar maior número de leitores, influenciando-os quanto às opiniões.

A ascensão dos jornais está intimamente ligada à ascensão da 'opinião pública' (BURKE, 2002). Estes apregoam, como o exemplo do jornal Tatler, citado por Lima (2000, p. 31), que o burguês tem um papel muito mais útil à sociedade, pois eles estariam trazendo riquezas e, portanto, teriam muito mais "direito de chamar-se gentleman do que o cortesão que somente paga com palavras, ou do que o erudito que escarnece do ignorante". Cria-se, portanto, um novo mito a ser defendido e propagado, um novo tipo de honra, "a honra comercial". Sendo o mito essa possibilidade secreta na forma de explicar as manifestações culturais humanas, podemos concordar com Lima, quando afirma:

Este é, em síntese, o período em que o pensamento formula teórica e ideologicamente a justificação da racionalização dos negócios. (...) Ou seja, estamos a lidar com o período em que a burguesia, por seus representantes mais avançados, formula e desenvolve sua consciência classista (LIMA, 2000, p. 31).

Primeiramente, os jornais e, depois, o rádio e a televisão contribuem especialmente como um novo espaço para a veiculação, não só dessas novas formas de pensar, mas também como um novo e excelente espaço para veiculação de publicidade. Dessa forma, o que antes era feito por cartazes colocados em determinados lugares, pode, agora, alcançar um número bem maior de receptores e interferir em instâncias da vida que antes não eram alcançadas pelas relações mercantilistas de troca.

Fairclough (1990, p.198) explica o consumismo, a partir da onipresença da publicidade no cotidiano, possibilitada pela cultura e comunicação de massa, como sendo "uma característica do capitalismo moderno (...) em um nível sem precedentes de intervenção da economia na vida humana". Consideramos, portanto, que as peças publicitárias são produtos criados, essencialmente, dentro de um espaço público, dentro de uma cultura de massa. 
Interessa-nos, nesse trabalho, investigar de que forma ocorre essa esquematização repetitiva dentro dos anúncios escolhidos para o corpus, quais recortes culturais são feitos por intermédio das narrativas apresentadas aos leitores e de que forma os temas escolhidos para veicular o inventário perceptual, ao qual se desejam ligar as empresas BASF e Pfizer, são simplificados e reatualizados em cada anúncio. E o que podemos depreender dessas semelhanças ou diferenças de abordagens.

\subsection{Mola mestra da publicidade}

"Why be you, if you can be new".

(Fala do vilão do filme animado "Robôs", da produtora Blue Sky Studios)

Quando se anuncia: 'Liberdade é uma calça velha, azul e desbotada', com certeza não se está anunciando só um jeans, mas todo um sonho. A publicidade se alimenta do desejo, característica inerente ao ser humano, e o estimula em benefício próprio, usando-o como um moto perpétuo a fim de escoar a produção de bens dentro da sociedade capitalista. Ser seduzido por essa ou outras falas significa o desejo de entrar em outra realidade, em outra linguagem. $O$ desejo de sair do cotidiano ao qual se está aprisionado e aceitar apenas os aspectos desejados de uma realidade que é mostrada de maneira simplificada e tornada compreensível pelo produtor de uma história. $\mathrm{O}$ indivíduo é seduzido pelo próprio desejo de entrar em outro universo simbólico. E a linguagem é o lugar ideal da sedução.

Como todas as motivações básicas do ser humano são:

... condicionadas emocionalmente, o especialista recorrerá amplamente ao amor, raiva, medo, esperança, culpa e quaisquer outros sentimentos, emoções e impressões úteis que tem em vista. Via de regra ele desejaria despertar um desejo por algum objetivo (BROWN,1971, p. 24). 
Na publicidade, o verbo 'ser' aparece geralmente no imperativo: 'seja você também'. Isso significa, que em vez de aproveitar o que o indivíduo já é, exige-se uma mudança para uma nova forma de ser, aquela programada pela publicidade. 'Seja sócio de nosso clube'. O indivíduo é orientado para o futuro, para o tempo do desejo que, na verdade, nunca se realiza, pois a cada momento surge um novo desejo e é justamente desse mecanismo que a sociedade industrializada vai se alimentar.

Como embasamento para as pesquisas de motivação, os cientistas sociais que as realizam podem partir de diferentes abordagens:

... alguns trabalham em linhas adlerianas, raciocinando em função da busca do poder como impulso básico, alguns segundo linhas sexuais freudianas e outros se apóiam na tese de Riesman de que o grupo de referência é a principal fonte das opiniões dos indivíduos (BROWN, 1971, p. 176).

Este trabalho busca em Riesman as fundamentações para a discussão sobre o desejo. É importante definir o que o sociólogo Riesman (2002) propõe. Ele analisa três tipos de indivíduos sociais que se desenvolveram, primeiramente, a partir de sociedades não capitalistas, passando pelo surgimento do capitalismo, até sua fixação na forma atual.

O primeiro tipo seria o dirigido pela tradição - Trata-se do indivíduo que aprende a lidar com a vida por adaptação às regras e tradições. A comunidade lhe serve de modelo. São sociedades mais ou menos estáveis, que podem conter sistemas de castas e têm pouco desenvolvimento tecnológico. Ao inovador ou rebelde é reservado o lugar de xamã. Isto é, essa sociedade lida com a inovação ou rebeldia de maneira mais cuidadosa e as vê como uma forma mágica, como se, estes indivíduos, com dificuldade de adapatação, fossem capazes de traduções de outros possíveis planos da convivência, não disponíveis para a percepção do resto do grupo.

O segundo tipo seria o indivíduo autodirigido - Este vive numa sociedade que conta com mudanças que o desenvolvimento tecnológico provoca. Portanto, tem que contar consigo próprio e saber se adaptar às novas necessidades que 
surgem com esse desenvolvimento. Para que essa adaptação ocorra em segurança tem que dispor de um 'sistema geral de princípios', apenas a tradição não basta. Dentro dessa nova ordem na sociedade, criada a partir do desenvolvimento tecnológico, a mobilidade social é permitida, já que parte do princípio de que o homem se faz por si próprio e que o trabalho e a poupança o levam a um estágio melhor. É um indivíduo que vive em função do futuro, pois, contando apenas consigo próprio, tem que poupar para sua segurança e velhice.

Dentro dessa forma de viver, esse indivíduo deve aprender a se conter a fim de vencer tentações que o distraiam desse caminho de acumulação. Portanto, o prazer e a satisfação de desejos que não façam parte do objetivo final - a acumulação - devem ser reprimidos em nome da manutenção das relações sociais e da ordem estabelecida.

Em função das freqüentes mudanças tecnológicas, exige-se grande poder de adaptabilidade e em função da acumulação exige-se grande rigidez. Para os que não conseguem essa adaptação, restam os manicômios, prisões. Se tomarmos o trecho onde Dostoievsky (2000, p. 44) nos fala sobre a figura do antigo "Vater" alemão, no seu livro "O Jogador", teremos aí a descrição exata do comportamento do indivíduo de uma sociedade onde os indivíduos são autodirigidos.

O terceiro tipo: o indivíduo altero-dirigido - A condição essencial para a existência desse indivíduo são os meios de comunicação de massa e uma sociedade de intenso consumo. Ele está sempre orientado em relação ao modo de ser do outro. Não the basta mais seu sistema geral de princípios: "seus contemporâneos são a fonte para o indivíduo" (LIMA, 2000, p. 51) A única coisa que permanece constante são suas antenas, sempre ligadas para detectar sinais emitidos pelo seu entorno.

Para a existência desse indivíduo, supõe-se uma sociedade na qual a poupança não é mais estimulada, além da obsolescência das mercadorias que, por sua vez, é estratégia de mercado, destinada a salvar as indústrias da superprodução, além de uma conseqüência do avanço tecnológico rápido. A sua existência pressupõe, também, uma sociedade que já tenha resolvido alguns 
problemas econômicos, como por exemplo: acesso de seus membros aos bens de consumo, - mesmo que para cada grupo sejam destinados produtos diferentes além de indiscriminada potencialidade tecnológica (ibidem, p. 52).

Já que, aparentemente, todos têm acesso a tudo dentro de sistemas como esse, o consumo, nesse caso, não se dá mais pela quantidade, mas pela qualidade. Esse tipo de indivíduo está sempre à mercê de experts que se encarregam de dar conselhos sobre tudo. Daí, a imensa quantidade de livros de auto-ajuda editados diariamente, colunas de jornais e programas de culinária e de auditórios, sempre com algum "especialista", dando palpites sobre qualquer assunto, desde como aprender a respirar até como morrer de acordo com os avanços tecnológicos. Ele tampouco "dispõe de defesas contra a sua própria inveja." (RIESMAN, 2002, p. 143), já que seu centro está no outro e, conseqüentemente, o outro é seu rival, pois sempre tem algo que ele não tem

Tanto Brown como Haug chamam a atenção para o fato de que esse tão anunciado desenvolvimento tecnológico não precisa nem ser real no que diz respeito a novos modelos lançados no mercado. Brown (1971, p. 169) inclusive nos fala de uma "... obsolescência psicológica criada pela publicidade de modo que as pessoas ficam insatisfeitas com um modelo antigo".

Haug (1996, p. 53) chega a essa conclusão dizendo que existiria, inclusive, um mecanismo de detonação que, após alguns anos de uso, começaria a provocar defeitos nos mecanismos de determinados produtos, "... dando início a sua autodestruição interna depois de um tempo devidamente calculado". Outra estratégia pró-obsolescência, fácil de perceber no cotidiano, é o fim da produção de peças de reposição para modelos "fora de linha". O exemplo mais marcante é a florescente indústria de informática, que vai desde hardwares a softwares, que, às vezes, em questão de meses, tornam-se ultrapassados e deixam de ser fabricados.

Podemos achar um ponto de semelhança entre esses argumentos levantados por Haug e Brown e os argumentos levantados por Bucci; Kehl (2004). Esses últimos autores chamam a atenção para o fato de que o poder midiático é uma instância autônoma de tomada de decisões, e os indivíduos que dela fazem 
parte são apenas seus empregados, na verdade, muitas vezes, sem poder efetivo de atuação perante os acontecimentos.

Poderíamos ver essa relação entre a inovação tecnológica das indústrias juntamente com a 'obsolescência psicológica' criada pela publicidade, como mecanismos que funcionam conjunta e independentemente de seus subordinados. É necessário 'inovar' para poder escoar bens de consumo, sem se perguntar por que isso é 'necessário', e dessa forma os indivíduos tornam-se "sujeitos inconscientes do capital" (ibidem, p. 22).

Nesse caso, a própria identidade é passível de adaptações ou até de mudanças de acordo com o pedido pelo mercado. O indivíduo é caracterizado pela inconclusão, permanece preso a um desejo do qual não tem o controle e que definitivamente jamais se resolve numa enorme lista de aquisições em um dia de compras. Isso provoca um comportamento camaleônico sempre se adaptando em função do desejo do outro, no caso, o outro pode ser o mercantilismo que procura invadir todas as instâncias da vida do indivíduo. O indivíduo altero-dirigido, deve ter, atualmente, não apenas uma antena para detectar sinais emitidos por seu entorno, mas um radar, já que os sinais são de número quase infinito, desde que a globalização possibilitou a internacionalização não só do capital, mas também de culturas.

Esse processo camaleônico poderia ser explicado a partir do que é afirmado, abaixo, por Aglietta:

O mimetismo é o processo chave que permite tornar inteligível a evolução das necessidades em um sujeito marcado pela inconstância do desejo, por sua indeterminação. Impotente para encontrar em si mesmo uma regra que permita selecionar os produtos, o indivíduo irá voltar-se para os outros, no sentido de buscar orientação para sua busca. Em circunstâncias que privam o indivíduo de todo conhecimento a priori, imitar o outro é a sua única estratégia racional (Aglietta, 1990, p. 18).

O sujeito vê o outro como algo que the falta e é justamente desse outro que espera receber as diretrizes para se tornar pleno, no caso, igualar-se ao outro que é seu modelo. Considerando verdadeira essa característica, a rivalidade passa a 
ser conseqüência de identidades dos mesmos desejos em indivíduos ou grupos diferentes (GIRARD, 1990). O outro é, portanto, modelo e rival.

Talvez seja esse um dos motivos pelos quais a sociedade capitalista, e dentro dela o indivíduo altero-dirigido, é tão marcada pela competição ao invés de solidariedade. Esta sociedade se sustenta na rivalidade dos mesmos desejos. E a publicidade utiliza, muito bem, a afirmação de Fromm (1990, p. 111): “...; os seres humanos receiam mais ser marginalizados do que morrer".

Esse mimetismo, na verdade, é uma qualidade humana. O ser humano assimila boa parte de sua educação/socialização de forma inconsciente, e o faz como se fosse em blocos, por isso é tão difícil mudar atitudes, porque estas são ligadas à emoção e ao afeto. É uma presa fácil de sua inveja, medindo-se pelo outros ao seu redor. Se a sociedade estimula o lado competitivo ao invés do cooperativo, esse indivíduo tem sempre a sensação de estar perdendo algo.

A publicidade trabalha com essa incompletude, característica básica do ser humano. O 'ter' entra como a medida da completude humana. Ou como diz Fromm (1980, p. 43): "No modo ter de existência, meu relacionamento com o mundo é de pertença e posse, em que quero que tudo e todos, inclusive eu mesmo, sejam minha propriedade". Por este motivo a publicidade adquire uma existência tão poderosa no "modo ter" de existência do indivíduo altero-dirigido, pois nesse modo, a reação à publicidade é a aquisição ou o desejo da aquisição do que é por ela veiculado, e não uma possível interação crítica.

Uma imagem constantemente acionada para definir o consumidor em suas relações com o consumo é a figura mitológica de Tântalo que, por haver roubado os manjares dos deuses, foi condenado a ver distanciar de si a água que ia beber e os frutos que estava por apanhar das árvores. Tântalo tornou-se símbolo do consumidor moderno, expressando esse vazio eterno e indefinido, confrontado à necessidade do consumidor, que corre atrás de meras imagens publicitárias, fadado a não se satisfazer jamais com suas aquisições, um consumidor contumaz.

Se, para alguns o papel da publicidade é provocar necessidades, para outros, isso é impossível. Porém, essa discussão apenas mascara o fato de que se provocar necessidades é impossível, a transferência de desejos não é. Há, 
portanto, a transferência de uma necessidade real para outra, criada pela publicidade. Por ex., a sede (carência real de água no organismo), para produtos artificiais, como Coca-Cola, sorvete Kibon etc.

A própria publicidade se encarrega de provocar ou transferir desejos ou necessidades e de fornecer as respostas. E uma das principais funções do slogan seria justamente ser breve para provocar a lembrança dessa necessidade para os consumidores a fim de orientá-los para a ação desejada: a aquisição. Tanto que ele será um bom slogan quanto mais conseguir assegurar/embutir/guardar em si necessidades conflitantes, que são estados normais da realidade em sociedade, já que esta, para se manter coesa, tem que comportar em si vários tipos de conflitos, como já foi mencionado, a respeito do 'mito fundador', proposto por Girardi (1990).

Se o valor de uso dos produtos à disposição no mercado é real ou não, isso pouco importa, pois esse valor é apenas um chamariz. O que importa é que a mercadoria na vitrine seja comprada, pois o surgimento da moeda provoca a emancipação do valor de troca da mercadoria de seu valor de uso. Quase não tem mais importância a função do objeto ou serviço que adquirimos.

O valor de troca continua dependente da moeda que possibilitou igualar todos os produtos. "Com o dinheiro - no início, a mera reificação de uma função de troca - surge no mundo um poder com uma qualidade nova: a riqueza abstrata, o valor de troca emancipado" (HAUG, 1997, p. 28). Sendo o tertium comparationis, a moeda deixou para trás o valor real de cada objeto, que era o seu valor de uso.

Se, além disso, com a divisão do tempo, através do relógio, em horas, minutos e segundos, pode-se contar o tempo gasto para a fabricação de cada objeto, a moeda passa a contar o tempo gasto para se fabricar algo, não mais o objeto a ser vendido. São várias etapas que vão destruindo o valor de uso. Ou como diz Marx (apud HAUG, 1997, p. 35): "Ansiosa pelo dinheiro, a mercadoria é criada na produção capitalista à imagem da ansiedade do público consumidor. Essa imagem será divulgada mais tarde pela propaganda, separada da mercadoria."

Por isso há a "necessidade" da publicidade. Há que se pesquisar muito bem como despertar, no indivíduo, a necessidade do uso, para que surja o desejo 
da necessidade de troca. Pouco importa se esse valor de uso é real. A função da publicidade é promover a ligação entre valor de uso e valor de troca, é dar sentido ao objeto junto aos consumidores.

Podemos exemplificar essa estratégia com a história do café e do chá. Em determinada época, a Inglaterra e os Países Baixos exploravam lugares onde se cultivavam o chá e o tabaco, e deles faziam apologia, chamando-os de 'plantas divinas', 'medicinais', pagando, inclusive, a médicos da época para compactuar com isso, prescrevendo-os como medicamentos, além de escrever longos artigos 'científicos' a respeito de sua eficácia.

Enquanto isso, os países católicos, como Portugal e Espanha, que exploravam colônias onde se cultivavam, principalmente, chocolate e açúcar, tinham discurso bem diferente. Nesses países, o clero pregava contra o chá e o tabaco, seus concorrentes, chamando-os de 'coisas do demônio'.

Isso faz lembrar a grande discussão que houve há algumas décadas a respeito dos males provocados pelo açúcar e pelos adoçantes, ambas as facções pagando pesquisas que comprovassem os seus pontos de vista. Como se pode perceber, o uso que se faz da ciência tampouco é neutro.

Um exemplo recente a respeito novamente do café e do chocolate. Esses dois produtos, depois de serem tangidos como não saudáveis, voltam, hoje, à mesa da população como excelentes estimulantes tanto para o início de um dia saudável como para a inteligência. Estes são excelentes exemplos de como funciona a criação de verdades junto aos consumidores (ou criações de sentidos, em geral).

O que concorre não é seu valor de uso, mas a imagem que a publicidade cria do objeto. Uma imagem que é a imagem da imagem, segundo Baudrillard (2000), um simulacro. O café e o chá deixam de ser simples bebidas e passam a ser avaliados por outros sistemas de valores. O que está em jogo é a sensação de vender ao cliente $o$ fato de ele ser especial e estar adquirindo algo que 0 diferencie dos outros, dentro de produtos produzidos em massa.

O conteúdo de realidade da mercadoria vai se perdendo cada vez mais - aí Haug se encontra com Baudrillard - o produto tem que destruir seu vínculo com a 
realidade para poder entrar no mundo da abstração, do simbólico e existir a partir da imagem cada vez mais distante de sua realidade.

Se o valor de uso fosse universalizante, isto é, teoricamente igual para todos, ele perderia a capacidade de se valorizar. É através da publicidade que se reduz ou se anula o fator universalizante, que é justamente sua produção em massa, em série, como a maioria das coisas que atualmente se vende. Se existe a possibilidade de valorização desses produtos de série, absolutamente iguais, isso é um efeito da publicidade. Esse é o papel da publicidade. A estetização da mercadoria é essencial nessa parte.

Haug (1997, p. 67) dá o nome de 'tecnocracia da sensualidade' a esse domínio que a fascinação exerce sobre os indivíduos. Fascinação significa simplesmente que os indivíduos sentem-se atraídos por determinadas formas estéticas. Isso com certeza não surge com o capitalismo. Os índios com todas as suas plumas, as culturas com seus ritos e cultos religiosos, as igrejas com todos os seus jogos arquitetônicos e artísticos, de acordo com suas épocas, já faziam isso. São elementos de construção de uma comunidade e não podem ser desvinculados do contexto histórico, social etc. em que acontecem. Todas as sociedades "são vítimas e algozes de seu próprio simbolismo e de sua própria mitologia“" (ROCHA, 1985, p. 11), todas estão sujeitas aos seus próprios rituais de explicações mágicas, filosóficas, científicas a respeito dos elementos de seu entorno.

A sociedade capitalista tem que lidar com as encenações/manifestações da publicidade, a nova forma de ritual para explicar elementos de sua realidade e que faz do desejo de ser o outro, sua mola mestra.

\subsection{Mito}

Um dos objetos de nossa análise será o uso que a publicidade faz dos mitos à disposição do grupo social no qual pretende atuar; de que forma ela se apropria dessas narrativas, isto é, que modernização ou simplificação faz desses mitos; de que maneira a utilização desses elementos mitológicos indica 
semelhanças ou diferenças quanto ao que se julga acordado entre os consumidores em cada país. Para tanto será definido o que é mito, quais suas funções, de que forma ele é usado na publicidade. Nas análises serão discutidos quais os elementos mitológicos escolhidos pelos construtores dos anúncios.

\subsubsection{O Mito e sua função}

Os mitos são histórias desenvolvidas pela coletividade a fim de tentar fornecer modelos de vida para si mesma. São formas de organização das experiências coletivas. Podem ser estudados como formas de explicar a situação humana ao longo do decorrer da história da humanidade, como uma tentativa de relacionar o ser humano à natureza e aos seus semelhantes, ou mesmo como expressão de sonhos comunitários, baseados em resíduos arcaicos - arquétipos que estão com a civilização desde sua formação, submersos no inconsciente da psique humana (JUNG, 1964).

Levando-se em consideração que as sociedades são sempre compostas de vidas que se enfrentam, se antagonizam, buscando viabilizar a realização de seus interesses, não se encontra uma sociedade homogênea, na qual todos concordem sobre tudo. Portanto, é de se esperar que não exista apenas um mito para cada tentativa de explicação do mundo. Podem coexistir vários mitos contraditórios, tentando fornecer modelos de explicação para os mesmos problemas, e o próprio mito, na maioria das vezes, traz em si diferentes possibilidades de leitura.

Esse mecanismo de 'comportar em si diferenças' deixa perceber o que foi proposto por Bakhtin (1995) em relação aos signos lingüísticos. O que ocorre nestes, ocorre em signos do sistema mitológico e em outros. Há sempre vozes discordantes que se fazem ouvir, embora uma hegemonia seja almejada por parte das classes que se estabelecem no poder.

Essa fala mitológica, cheia de contradições que procuram explicar os mesmos fenômenos, serve para criar um sistema de ambigüidades úteis tanto para dar conta do enfrentamento dos diversos grupos que compõem a sociedade 
quanto para dar conta da necessidade de mudanças e adaptações, fundamentais para a viabilização da convivência social. Essa é a riqueza da linguagem mítica, pois a não literalidade de suas interpretações admite diferentes formulações, de acordo com os acontecimentos e conhecimentos que vão sendo adquiridos na história do grupo a que servem (HILLMAN, 1989).

O que nos interessa na forma da narrativa mitológica dentro da publicidade é a possibilidade de identificação do ser humano com alguns aspectos da história que está sendo contada. A criação de mitos é a comprovação de que o ser humano tenta perceber e explicar o mundo por intermédio de narrativas, que procuram realçar determinados aspectos de uma história e apagar outros que não sejam interessantes para quem as conta, buscando, sempre, uma forma de tornálo compreensível para os membros de sua comunidade.

Esse processo busca uma categorização, portanto, uma ordenação e simplificação dos elementos da natureza, da sociedade e do ser humano, facilitando suas ações no meio em que vive. Com as categorizações, ocorre o realce de algumas qualidades humanas que são vistas como representativas, ou desejadas, em determinados acontecimentos, assim como também procura explicar características indesejadas que o ser humano carrega consigo.

Toda cultura é responsável pela criação de um sistema de mitos que procura explicar sua posição na natureza no decorrer da história. Nessas narrativas mitológicas, encontram-se as histórias da humanidade que vêm sendo contadas há milênios, por isso seu poder de ação sobre quem as ouve ou vê. Por intermédio do mito, o homem sente-se representado, 'está em casa' (BARTHES, 2003), se reconhece como parte da comunidade.

Esses mitos necessitam ser constantemente readaptados no tempo, atualmente, de forma muito mais rápida, tendo em vista a velocidade com que as mudanças estão ocorrendo. Vem daí a 'necessidade' de mitos descartáveis, como os elaborados e cultuados pelos meios de comunicação de massa. Esses mitos 'voláteis' estão presentes no cinema, na música, na TV etc. O sucesso de hoje é o ostracismo de amanhã. 
Campbell (2002, p.13) define quatro funções para os mitos, que serão apresentadas abaixo, resumidamente:

1 - Função mística - seria a tentativa de, através de uma narrativa, entender e, de uma certa forma, controlar o 'mistério da vida do universo'.

2 - Função cosmológica - a tentativa do ser humano de se colocar em um determinado lugar nesse cosmos, nesse 'mistério'.

3- Função sociológica - trata de organizar, instaurar, justificar e defender uma certa ordem social. Não é por acaso que a Odisséia foi a narrativa escolhida para nortear as sociedades gregas, romanas e posteriores. Dentro de uma sociedade imobilizada, composta por aristocratas que detinham o poder das terras, surge o mito de um herói navegador e ardiloso feito Ulisses, que bem serviria de modelo e ao mesmo tempo justificaria a existência de uma outra classe, que eram os navegadores comerciantes.

4- Função pedagógica - que nos ensina como viver, fornecendo modelos de vida. É essencial para a função sociológica. Um exemplo desse uso é a figura do 'príncipe encantado', citado no anúncio da Pfizer brasileira. Imagem esta vinculada, principalmente, ao imaginário feminino (CAMPBELL, 2002) e que faz parte dos mitos orientadores, pedagógicos. Continua sendo usada para "educar" mulheres a esperar homens que, se já não exercem sozinhos o papel de provedores, continuam trazendo a promessa de um amor eterno. São príncipes encantados, que as desposarão e delas nunca se separarão, não importando que tipo de problema possa ocorrer. Ao mesmo tempo, esse mito, também, é utilizado para "educar" homens a lutar bravamente para conseguir o que é difícil, afinal esta é uma das facetas do herói.

Para o mesmo autor (1990, p. 16), "os mitos são sonhos do mundo. São sonhos arquetípicos, e lidam com os magnos problemas humanos", aos quais todos estamos expostos, em todos os momentos de nossa vida. Quais seriam esses problemas? Angústias que necessitam ser amainadas e que seguem com a humanidade desde os primórdios, como medo de catástrofes, da fome, da morte, da doença, do envelhecimento, da finitude, de mudanças. Enfim, o desespero diante de um universo inalcançável etc. No entanto, os mitos não existem somente 
para explicar angústias humanas, existem mitos para momentos de celebração, de felicidade. Os mitos são representações mais elaboradas culturalmente dos arquétipos.

Estes, de acordo com Jung $(1963,1964)$ são imagens universais, resíduos arcaicos, que fazem parte do inconsciente coletivo, isto é, são as mesmas para todos os indivíduos e podem ser rastreadas, retroativamente, dos dias de hoje até o início da formação da humanidade. Tem a ver com a vida humana instintiva, está próximo ao fisiológico, ao inconsciente e por isso é tão potente. É uma teia de imagens simbólicas que segue junto com a humanidade, cujo pensamento criativo, imaginativo, mítico aparece como conseqüência do surgimento de estruturas cognitivas capazes de ordenar e representar essa ligação com a realidade que segue junto com a humanidade desde o seu surgimento.

Não entraremos aqui na discussão dos motivos que tenham levado os seres humanos ao desenvolvimento dessas estruturas. Sabe-se que existe um processo que possibilitou e possibilita (HILLMANN, 1989) a ordenação e representação da realidade, criando, dessa forma, uma possibilidade de elaboração e tentativa de compreensão de questões e problemas que se apresentam à humanidade. E isso ocorre, muitas vezes, de forma metafórica. Por isso, também, o uso de histórias que procuram traduzir em termos compreensíveis esses momentos 'misteriosos' da humanidade.

As imagens universais, arquétipos, são formas de apreensão repetitivas, se expressam, porém, de diferentes maneiras, de acordo com cada cultura que as cria. As formas podem variar, mas o conteúdo do arquétipo é o mesmo. É um mecanismo que serve para manter o ser humano na unidade, apesar de toda sua multiplicidade cultural na forma de perceber o mundo.

É justamente essa característica de que existe um modelo, uma estrutura repetitiva a ser seguida, que permite à publicidade - e a outras formas de narrativas, como os folhetins apresentados nas televisões brasileiras, em telas de cinema americanas, em revistas de celebridades - desmembrar o mito em partes que lhes interessam e somente a essas dar permissão de voz. 
A publicidade se apropria das características que lhe são úteis em determinado momento e dessa forma retira do mito suas características de ambigüidade e, portanto, sua potência enquanto instrumento que comporta oposições que funcionam de maneira complementar.

Esse mecanismo de simplificação é útil para explicar uma realidade complexa, como já foi discutido anteriormente, quebrando arquétipos em clichês e estereótipos. É dessa forma que funciona a publicidade, esquartejando o mito original e criando o que interessa ao mito midiático. Esse mecanismo será demonstrado por intermédio dos anúncios analisados.

A publicidade utiliza-se de mitos com o intuito de provocar algum tipo de identificação, empatia, por parte do leitor, com a narrativa apresentada. Esta narrativa serve para explicar, justificar e estimular nossos comportamentos, enfim, para encontrar o caminho pelo qual se deve andar dentro do labirinto que se tornou o mundo do consumo. Ela descortina, com seus mundos de eterna juventude, beleza e felicidade, o acesso ao paraíso, tão propagado pelas religiões. Enquanto estas últimas exigem do ser humano alguma dose de sacrifício e postergam o prêmio para o pós-morte, a publicidade traz o paraíso para o alcance da mão - e do bolso. Sem esquecer do mito Tântalo, a busca por esse 'paraíso' deve ser constantemente refeito a partir do desenvolvimento de novos desejos.

Naturalmente, é importante se compramos ou não o que é anunciado, mas é mais importante ainda que sejamos 'educados' pelo mundo publicitário. Veja-se a modulação de comportamentos propiciada pelos meios de comunicação de massa e seus produtos, como modas, músicas, filmes e novelas. Hoje, elas são tão "contaminadas" pela publicidade, que fica difícil se distinguir uma 'obra' dessas de uma peça publicitária.

Alguns elementos mitológicos se sobressaem nas análises que foram feitas. Entre eles, alguns arquétipos masculinos e femininos, como a figura do Herói, do Grande Pai, da Grande Mãe e da Donzela.

Essas expressões mitológicas são usadas para, mais facilmente ancorar, no espaço mental do leitor, o inventário perceptual com o qual essas empresas desejam ser vinculadas. As figuras mitológicas, a serem acionadas, devem 
respeitar os acordos culturais de forma a angariar a empatia dos leitores e não provocar dissonâncias cognitivas. A discussão dos elementos mitológicos, estudados abaixo, se fazem necessários, pois nos dois países, diferentes figuras mitológicas são acionadas, sistematicamente, para os respectivos anúncios.

Essas categorias mitológicas de análise, acionadas em conjunto com categorias lingüísticas e visuais possibilitam uma visão mais consistente das diferenças e semelhanças analisadas.

O herói, segundo Campbell (1997), apresenta um ciclo, o qual discutiremos, resumidamente, abaixo.

O herói é um ser do cotidiano - pode ou não já nascer predestinado a grandes feitos - que ouve um chamado para um mundo de aventuras, normalmente trazido por algum arauto, oráculo, vidente. Esse chamado é como uma imposição da figura do Grande Pai, o princípio masculino, que é a exigência arquetípica de que o indivíduo siga o seu caminho na vida e saia do domínio da Grande Mãe, seu par complementar, arquétipo da segurança do útero materno, doadora da fertilidade, preservadora da vida, do recôndito do lar, do aconchego do fogo da cozinha que mantém a casa unida e que procura a todo custo evitar mudanças. Esta última não está interessada no individual, mas no grupo que deve se multiplicar.

Por parte do herói, a princípio há uma tentativa de negação ao atendimento desse chamado, já que há perigos, muitas vezes mortais, que se impõem à vitória. Caso a negação se conclua, há o prenúncio de uma tragédia, pois a profecia deve ser cumprida, já que a função do herói é salvar a comunidade de um perigo iminente, ou trazer algum conhecimento que a salve.

Depois da resistência ao chamado, há a aceitação e aí surge, em uma ou várias etapas, a figura do 'mentor'. O mentor é uma das faces do Grande Pai que pode vir na forma de um ancião/ã, uma bruxa, um animal, um professor/tutor etc. Estas são algumas figuras que dão ao herói um conselho, conhecimento esotérico, amuleto ou qualquer outra coisa que permita que o herói obtenha a vitória em suas provações. 
Obtida a vitória, mesmo que essa possa significar sua morte ou simbólica ou real, o herói deve retornar ao convívio dos seus, agora trazendo a iluminação, as boas novas/ o evangelho ou o segredo adquirido com a empreitada bem sucedida, que vai possibilitar que a comunidade da qual partiu seja restaurada, salva de algum perigo, ou ganhe um conhecimento, como o fogo no caso do mito de Prometeu.

O herói é um dos elementos que mantém a comunidade coesa, muitas vezes com sua própria morte, que serve como expiação dos erros da comunidade. As formas com que se expressa este mito, com as suas tarefas, os seus significados e suas funções, devem ser atualizadas de acordo com a época que veste seu modelo. Como este mito está sendo utilizado dentro da cultura de massa, e mais especificamente dentro da publicidade, é óbvio que o recorte dessas qualidades que o tornam uma figura complexa, será simplificado.

O Herói representa o princípio masculino dinâmico que responde pelas mudanças necessárias nas sociedades. Este princípio pode aparecer na figura de desportistas, soldados, bombeiros e outros personagens, que indicam dinamismo e coragem. Um de seus pares complementares é a figura do Grande Pai, o responsável pela manutenção da 'ordem' e também da 'razão' que justifica essas “... regras organizativas e normativas, em leis, e num sentido de ordem hierárquica" (RANDAZZO, 1997, p. 141).

O Grande Pai pode ser reconhecido nas figuras do/a professor/a, mentor/a, juiz, padre etc., podendo assumir facilmente o papel de conselheiro em momentos difíceis. Justamente o complemento 'racional' do herói para que esse alcance 0 sucesso. Como arquétipo, ele é importante no momento em que explica a quebra da hegemonia do princípio feminino, este, imerso em seus mitos ligados aos infinitos ciclos da natureza. A consciência da ordem hierárquica patriarcal surge com a possibilidade do uso da racionalidade para libertar-se do poder desse princípio feminino.

Se a mulher, que, a princípio, era tida como responsável pelos mistérios da criação da vida, numa fase da sociedade baseada ainda na matrilinearidade, passa a ser identificada com o princípio incapaz de controlar a força do próprio 
comportamento tanto sexual como racional e, por conta disso, historicamente, é penalizada como 'ser de insaciável luxúria'. Enquanto isso, o princípio masculino passa a ser encarado como sendo o responsável pelo gerenciamento da vida em sociedade, pela "ordem" e pelo uso da "razão". É a justificativa do estabelecimento de uma sociedade baseada na força da patrilinearidade e de uma rígida escala hierárquica. Daí, a existência de mitos que traduzem esse arquétipo, como "Zeus", do panteão grego, e outros deuses masculinos mais modernos terem substituído poderosas deusas de então (BRANDÃO, 1993).

O par complementar do Grande Pai é a Grande Mãe. O princípio feminino estático, preocupado com o que se desenvolve dentro de si ou no aconchego do seu lar ou até onde chega seu raio de alcance. Esse princípio feminino pode ser reconhecido em várias culturas que ainda consideravam a terra como uma deusa que alimentava a todos com sua fertilidade incansável. Ainda é associado arquetipicamente a uma casa, a um barco que carrega seres dentro de si, que transporta e alimenta sem impor condições e, portanto, representa a figura feminina como eterna provedora. É apresentado, segundo Jung, por:

Qualquer coisa profunda - abismo, vale, chão, e também mar e o fundo do mar, fontes, lagos e mananciais, a terra, o mundo subterrâneo, a caverna, a casa, e a cidade - são todos partes desse arquétipo. Qualquer coisa grande e acolhedora que contenha, abrace, envolva, defenda, abrigue e alimente outra coisa menor, pertence ao primordial reino do matriarcado (JUNG, 1985, p.158)

Lembrando que os mitos sempre têm aspectos ambíguos, positivos e negativos. $E$ é isso que os torna tão ricos. No caso dessa mãe que ama incondicionalmente, a sua ambigüidade pode se apresentar como a mãe que pode se tornar terrível, simbolicamente antropofágica, em momentos tais como o de aceitar, justamente, a separação de seus filhos

O contraponto desse princípio feminino estático, eterno provedor, que se apresenta sob a forma de professora, religiosa abnegada etc., são os seus arquétipos complementares da donzela virgem assim como o da donzela sexualmente insaciável, ambas à disposição do masculino, mitos tão explorados ao longo do estabelecimento da patrilinearidade. 
A eterna provedora, que antes era admirada por sua potência fecunda passa a ser combatida pelo mesmo motivo. Surge, como par complementar a fêmea de sexualidade incontrolável, responsabilizada pela sedução do elemento masculino, assim como pela traição: "A história e a mitologia estão cheias de mulheres que traem os homens indo para a cama com outros homens" (RANDAZZO, 1997, p. 108).

O uso de alguns elementos mitológicos mencionados acima e outros, puderam ser claramente identificados nos anúncios que compõem o corpus desta pesquisa e serão discutidos na análise.

\subsubsection{Mitologia na publicidade}

Randazzo (1997), explicando como uma marca ocupa espaço no mercado, coloca-a como tendo, além de aspectos físicos, também aspectos psicológicos. Os aspectos físicos, como já foi dito, são o preço, utilidade, apresentação na prateleira etc. Entre 'atributos físicos', estão muitas vezes a PUV (Proposta Única de Venda), que é o que teoricamente diferencia a marca no mercado, ou o que é novidade.

Esse mecanismo pode ser percebido com o lançamento de cosméticos, por exemplo, que, para sobreviverem entre tantas marcas, estão sempre procurando criar diferenças. Alguns exemplos de aspectos físicos dos produtos no cotidiano: O Seda Shampoo: 'Com essências naturais', ou o bloqueador solar Nívea: 'fórmula com proteção UVA/UVB e resistente à água'.

Além desse aspecto físico há uma "entidade perceptual que existe num espaço psicológico do consumidor" (RANDAZZO, 1997, p. 25) e que não é de forma alguma estática, pelo contrário, tem que ter um dinamismo que acompanhe as tão rápidas mudanças que ocorrem atualmente. Seriam os "benefícios decorrentes do uso" seriam . No exemplo do Seda Shampoo citado acima: cachos definidos, alongados e hidratados, além da imagem da moça no produto, que naturalmente tem um lindo cabelo e de uma certa forma se vincula ao elemento mitológico 'donzela', que se diferencia das demais, justamente pelo uso do 
produto. No caso do bloqueador solar Nívea: proteção segura contra queimaduras e o envelhecimento precoce da pele, muito alta proteção, tudo isso reforçado pela imagem da Giselle Bündchen.

Para tornar-se uma entidade perceptual na mente do consumidor, deve ser criado um "inventário de imagens, simbolismo, sentimentos e associações" (ibidem, p. 27) que o público ao qual se destina a mensagem deverá reconhecer. Esse 'inventário perceptual' é criado com o intuito de seduzir e persuadir o leitor. Por intermédio dessas pistas, é possível ter acesso à forma como esse consumidor é visto pelo produtor do anúncio e a determinados acordos da sociedade que afloram na argumentação multimodal construída no anúncio, já que não se pode ter acesso à mente do consumidor.

O autor afirma que esse inventário existe de maneira pouco consciente na mente dos consumidores. Afirma também que para isso os publicitários fazem uso de uma 'mitologia latente' ao produto ou serviço que se anuncia:

Essa mitologia abarca a totalidade das percepções, crenças, experiências e sentimentos associados ao produto. A mitologia latente do produto decorre das experiências do consumidor com 0 produto genérico, e também com a história, os fatos e o folclore que o cercam... (ibidem, p. 25)

Os aspectos, físicos e "benéficos", ligados ao produto, fazem parte da realidade que é criada na mente do consumidor. Esse inventário perceptual que é percebido pelo consumidor do anúncio, de maneira subliminar, é a realidade mais importante.

Essa 'mitologia latente' ultrapassa as características físicas ou o uso que se faz do que se quer vender. Ela é criada levando-se em consideração o tipo de imagem que o consumidor de determinado produto ou serviço gostaria de ter de si próprio ao se ver retratado enquanto personagem usuário desse produto, serviço, marca. Dessa forma, tenta-se criar uma afetividade entre marca e consumidor. Aí, entram aspectos culturais, pois deve-se ter muito cuidado para não se criarem imagens 'dissonantes cognitivamente'. (RANDAZZO, 1997) 
As informações, narração, personagens veiculados no anúncio devem estar de acordo com os valores, crenças e desejos dos consumidores. Essa afetividade deve também ser criada em cima de scripts conhecidos ou que possam ser reconhecidos pelos leitores. Esses aspectos de imagens dissonantes ou consonantes com a identidade dos indivíduos não são válidos apenas para anúncios publicitários, mas para o cotidiano, para processos de aprendizagem etc.

Para Randazzo (1997), a partir do momento em que o consumidor potencial do produto é representado no anúncio como uma imagem, um símbolo do que ele gostaria de ser, passa-se uma imagem mitologizada, onde apenas alguns aspectos de um todo são realçados.

A imagem mitologizada que se cria é "um sistema semiológico segundo" no dizer de Barthes (2003, p. 205). O consumidor já não é mais ele próprio, inteiro, mas algo que se acopla ao desejo de ser outro, onde apenas as características positivas e desejáveis ocupam todo o espaço de significação. É por esse motivo que na publicidade a imagem visual se impõe com tanta força, pois ela é lida muito mais rapidamente "... ela se transforma numa escrita, a partir do momento em que é significativa" (ibidem, p. 205), isto é, essencial para a construção dos sentidos.

Barthes (2002, p. 11) se interessa por mitologia, justamente por indignar-se com a normalidade com que as coisas são veiculadas através da mídia, no cotidiano das pessoas, nas artes etc. Sua indignação ocorre porque percebe a "naturalização" de coisas, dos fenômenos sociais e culturais que fazem parte, não do mundo natural, como um terremoto, mas do decorrer da história, isto é, de um processo de mudanças, desde o seu surgimento até a atualidade, e são por ela determinados, mas que são constantemente insinuadas pela mídia como conseqüências da natureza das coisas. Esse processo serve para ofuscar relações históricas e cria uma realidade envolta em nebulosidade que aparece como estado original do ser.

Da mesma forma que ocorre a tentativa da naturalização de coisas, fatos e fenômenos históricos, ocorre a tentativa de naturalização da publicidade. Esta não deixa de ser, como outros fenômenos sociais, um fenômeno que se encontra naturalizado e perfeitamente integrado à paisagem cotidiana e embora muitas 
vezes não mais seja percebida, faz parte de nossas vidas, muito mais do que desejaríamos admitir. As categorias de análise que servem de parâmetro para a $A C D$, assim como investigar usos de elementos mitológicos, são formas de desmistificar essa naturalização e trazê-la para fora da rotina onde está imersa, questionando esse convívio.

Essa naturalização da publicidade ocorre com a reorganização do cotidiano, apagando possíveis conflitos culturais, econômicos, ideológicos etc. Dela desaparece, por exemplo, o percurso que o produto faz desde sua produção até sua venda. Como desaparecem, também, conflitos econômicos ligados à produção e ao poder de aquisição das pessoas. As relações de produção e disponibilização no mercado são "higienizadas" e naturalizadas. Esse processo de inculcação traz consigo um projeto social em potencial capaz de fazer com que indivíduos assumam como seus alguns interesses que nem sempre servem a seus próprios grupos, mas sim aos grupos que os 'higienizam' e apresentam como 'naturais'.

Trata-se de uma tentativa de 'naturalização' da ideologia do cotidiano da sociedade de consumo. Nesta sociedade os objetos do consumo, 'naturalizados' pela publicidade, passam a dar forma e significado à vida cotidiana.

Uma maneira de conseguir desvendar essas características é buscar o inventário perceptual que se cria através da publicidade, pois é ela, a publicidade, que nos permite ter acesso ao tipo de vínculo afetivo que o publicitário tenta criar entre o consumidor e a marca, o produto ou o serviço. É dentro desse espaço que temos as narrações, feitas com determinada argumentação, com seus inúmeros sentidos e silenciamentos, com personagens e situações sedutores, sempre na tentativa de se ligar afetivamente ao consumidor.

As categorias de análise a serem usadas serão as que foram expostas: Herói, Grande Pai, Grande Mãe e Donzela. Será analisado de que forma a escolha e organização dos elementos lingüísticos e visuais que compõem o anúncio se cruzam com os elementos arquetípicos/mitológicos escolhidos para fundamentar as narrativas publicitárias. Por intermédio dessa articulação, podem ser demonstradas a que inventários perceptuais as empresas desejam ser 
vinculadas. Desejam a BASF ou a Pfizer serem ligadas a diferentes inventários perceptuais no espaço mental dos brasileiros e dos alemães? Se assim for, devem fazer uso de diferentes elementos mitológicos. 


\section{PROCEDIMENTOS METODOLÓGICOS}

O corpus deste trabalho foi pesquisado na revista semanal brasileira VEJA e na revista semanal alemã DER SPIEGEL.

Segundo dados colhidos em sua página, na Internet, a impressão da revista VEJA apresentou uma tiragem média de 1.128.794, durante o mês de novembro de 2006, somando-se assinaturas e vendas avulsas. O número total de leitores foi avaliado em 7.950.000. Foi constatado ainda que $60 \%$ dos leitores encontram-se na faixa dos 20 aos 49 anos e $19 \%$, dos 50 anos em diante. $28 \%$ dos leitores pertencem à classe $A, 41 \%$ à classe $B$ e $22 \%$ à classe $C$. O nível de instrução apresentado por seus leitores é o seguinte: 37\% possuem nível médio e 39\%, nível superior. $47 \%$ dos leitores são homens e $53 \%$ são mulheres.

Segundo dados colhidos sobre a revista impressa 'DER SPIEGEL' no mesmo período, esta apresentou a tiragem média de 1.080 .669 exemplares, também contabilizando assinaturas e vendas avulsas, sendo o número avaliado de leitores por volta de 6 milhões. A faixa de idade dos leitores dessa revista é a seguinte: dos 20 até os 49 anos $52 \%$, dos 50 em diante, $43 \%$. Quanto ao poder aquisitivo, os que percebem até $1.000 €$ (mil Euros) representam 24\%; até $2.000 €$ (dois mil Euros), 40\%; ganham desse valor em diante, 26\%. Os leitores da revista DER SPIEGEL apresentam os seguintes níveis de escolarização: $42 \%$ têm diploma universitário ou licenciatura curta, 32\% são estudantes. Enquanto 23\% apresentam certificado de profissionalização técnica com ou sem especialização. $36 \%$ dos leitores são mulheres e $64 \%$ são homens.

\begin{tabular}{|l|l|l|}
\hline & \multicolumn{1}{|c|}{ VEJA } & \multicolumn{1}{c|}{ DER SPIEGEL } \\
\hline Tiragem & 1.128 .794 & 1.080 .669 \\
\hline N. estimado de leitores & 7.950 .000 & 6.004 .000 \\
\hline Poder aquisitivo: A & $28 \%$ & $26 \% 2000 €$ em diante \\
B & $41 \%$ & $40 \%$ até $2000 €$ \\
C & $22 \%$ & $24 \%$ até $1000 €$ \\
\hline
\end{tabular}




\begin{tabular}{|l|l|l|}
\hline \multicolumn{1}{|c|}{$\mathrm{DIE}$} & \multicolumn{1}{|c|}{$9 \%$} & \\
\hline Faixa etária: 20 aos 49 & $60 \%$ & $52 \%$ \\
50 em diante & $19 \%$ & $43 \%$ \\
\hline Sexo: masculino & $47 \%$ & $64 \%$ \\
feminino & $53 \%$ & $36 \%$ \\
\hline Nível de escolarização: & & \\
Superior & $39 \%$ & $42 \%$ \\
Estudantes & $37 \%$ & $32 \%$ \\
Médio-profissionalização & & $23 \%$ \\
\hline
\end{tabular}

A escolha das duas revistas, para servirem como parâmetros para a comparação dos anúncios, foi feita por estarem entre as publicações semanais mais lidas em seus respectivos países. São reconhecidas como formadoras de opinião, já que são das mais lidas em seus países. Ambas apresentam o mesmo tipo de conteúdo, isto é, trazem matérias sobre política, atividades culturais e assuntos os mais variados, tais como esporte, acontecimentos extraordinários e outros. Se dirigem a públicos semelhantes, quanto ao poder aquisitivo, ao nível educacional e à intenção de informação. Não foi levada em consideração orientação política dessas revistas.

Os anúncios recolhidos, tanto os alemães como os brasileiros, foram pesquisados, nessas revistas, durante o ano de 2005. Outras revistas como 'ISTO É' e 'ÉPOCA', - brasileiras - 'FOCUS' e 'STERN'.- alemãs -, foram também pesquisadas e foi constatado que alguns de seus números também apresentavam as mesmas publicidades.

Após várias análises comparativas dentro desse mar de anúncios inseridos nos veículos de comunicação, estabeleceu-se o problema de definir quais deles deveriam ser submetidos à análise.

Optou-se pela análise comparativa de anúncios que tivessem sido publicados pelas mesmas empresas, na Alemanha e no Brasil, durante o ano de 2005, e que pudessem funcionar como um diálogo, a partir do qual fosse possível perceber de que forma essas empresas buscam se colocar no espaço mental do 
consumidor tanto alemão como brasileiro. Com que tipo de argumentos se procura alcançar isso? E de que forma essas várias argumentações podem ser estudadas como compondo um diálogo? Essa abordagem determinou a escolha dos dois grupos de anúncios analisados: o grupo de anúncios da BASF e da Pfizer.

A opção pelos anúncios destas empresas ocorreu pelo fato de trazerem algumas características semelhantes e outras bastante distintas.

As semelhanças dizem respeito ao fato de que estas peças publicitárias da Pfizer e da BASF, aqui analisados, são exemplos de amálgama entre a publicidade institucional e a que é dirigida a consumidores individuais. Estes anúncios veiculam uma publicidade de prestígio, que faz parte de uma estratégia de comunicação mais ampla, entre o público e a empresa. Por intermédio destas, procuram 'vender', ao leitor, um inventário perceptual ao qual deseja ver ligada a sua imagem e demarcar um território no espaço mental do consumidor, mas também é veiculada uma publicidade, ainda que indiretamente, de seus produtos, assim como a importância de seu consumo junto à população.

A diferença é que ambos os anunciantes lidam com campos diversos da vivência humana - um voltado para o coletivo e outro abordando o universo íntimo, particular do indivíduo. Os anúncios da BASF trazem situações ligadas a resoluções de problemas de nível macro, como a participação da BASF do Brasil e da Alemanha, em pesquisas que levam ao desenvolvimento de tecnologia avançada, produções de substâncias químicas, petroquímicas, insumos agrícolas, tudo muito ligado a situações de empreendimentos industriais que se refletem no cotidiano de seus consumidores. Os anúncios da BASF, analisados neste trabalho, ao mesmo tempo em que falam sobre algumas características de seus produtos, colocam seu papel de importante contribuidora para o bem-estar social e a qualidade de vida, no Brasil e na Alemanha.

Por sua vez, a empresa Pfizer é responsável pela fabricação do medicamento Viagra, que atua sobre disfunção erétil. Esse campo de atuação atinge a área da atividade sexual, um assunto de foro íntimo, e ainda cercado de muitos tabus e preconceitos. Embora a Pfizer esteja fazendo a publicidade do 
medicamento, ela opta - por motivos que serão discutidos na análise -, por uma publicidade quase institucional.

Essa diferença das atividades das empresas leva a diferentes formas de abordagem do consumidor, o que pode ser visto nas estratégias montadas pelos anunciantes, o que nos dá boa margem de comparação entre as argumentações que são construídas com o objetivo de alcançar o consumidor.

A metodologia da disposição das análises será a seguinte: antes de cada análise, será apresentado o anúncio publicitário, para que não seja necessário ficar folhando até o final do trabalho, onde ele poderia ser apresentado como anexo. Em seguida, será feita a descrição de sua sintaxe visual e, a partir disso, um levantamento de quais implicações são criadas já pela disposição dos elementos imagéticos, lembrando que, juntamente com os aspectos lingüísticos, eles são responsáveis por evocar scripts e contribuir para uma argumentação coesa.

O anexo contém quatro transparências que podem ser usadas para melhor visualizar o jogo de formas geométricas com as quais os anúncios são compostos. Colocando-se as transparências sobre os respectivos anúncios, pode-se constatar, de que maneira essas formas atuam, subliminarmente, na construção da argumentação visual. $O$ anexo 1 e 2 são referente ao primeiro e segundo anúncio da BASF brasileira e o anexo 3 ao anúncio da Pfizer alemã e o anexo 4 ao último anúncio da Pfizer brasileira. Para os outros, não foi necessária a elaboração de material que permitisse uma melhor visualização.

Logo após, o texto do anúncio será transcrito e, no caso do anúncio alemão, traduzido para o português. E, então, analisado.

Será repetido, ao longo da análise, o trecho a ser trabalhado, de forma a facilitar a leitura do trabalho. Dessa forma, o leitor não terá a necessidade de ficar procurando o anúncio toda vez que sentir necessidade de visualizar seus detalhes. Para a análise, serão acionadas as categorias expostas na parte teórica do trabalho. Não serão usadas todas as categorias em todos os trechos. Os itens que interessam à pesquisa serão analisados de acordo com a ordem em que vão aparecendo nos anúncios e não agrupados por categorias. Por isso, a categoria a 
ser usada constará sempre na frente do item trabalhado e será grifada. Exemplo: operador argumentativo - aber - ... ou - expressão fraseológica - a olho nu -....

No final de cada anúncio analisado, será feita uma conclusão parcial e no final do bloco de comparação serão feitas conclusões finais. $O$ trabalho conta com um capítulo final que são as considerações gerais.

O corpus consta de cinco anúncios da BASF, sendo três da BASF alemã, dois da BASF brasileira e três da Pfizer, sendo um da Pfizer alemã - já que, durante todo o ano de 2005, foi veiculado apenas esse - e dois da Pfizer brasileira.

$O$ primeiro bloco a ser analisado contém os anúncios da BASF. A ordem será: primeiramente a BASF alemã e, posteriormente, a BASF do Brasil.

O segundo bloco consta dos anúncios da Pfizer, seguindo a mesma ordem anterior: primeiramente, será apresentado o anúncio alemão e, depois, serão apresentados os brasileiros.

A Pfizer alemã veiculou o mesmo anúncio durante todo o ano de 2004, 2005 e 2006, já a Pfizer brasileira veiculou diferentes anúncios durante esses anos. Como o corpus foi recortado em 2005, ficaram estes para a análise.

$\mathrm{Na}$ tradução das publicidades alemãs para a língua portuguesa, optou-se por permanecer o mais fiel possível ao texto original, de forma que a análise pudesse ser feita, aproximando-se da idéia do original. Isso não significa, em momento algum, que este trabalho parte do pressuposto de que traduzir é uma simples versão de um código para outro.

Reconhece-se que a argumentação elaborada pelos produtores, para fundamentar os anúncios, é feita por intermédio do conjunto de elementos lingüísticos-visuais que compõem um jogo muito bem pensado, quando se procura conduzir os leitores a conclusões e ações desejadas. Se o equivalente criativo em língua portuguesa fosse buscado, com certeza seria bem melhor, mas este não é o intuito desse trabalho. Mesmo assim gostaríamos de chamar a atenção para o fato de isso não ter sido feito. Reconhecemos esta limitação, ainda mais quando a base desse trabalho é a consideração de que o uso da língua não se restringe ao código lingüístico. 
5. ANÁLISE DE DADOS

BASF 


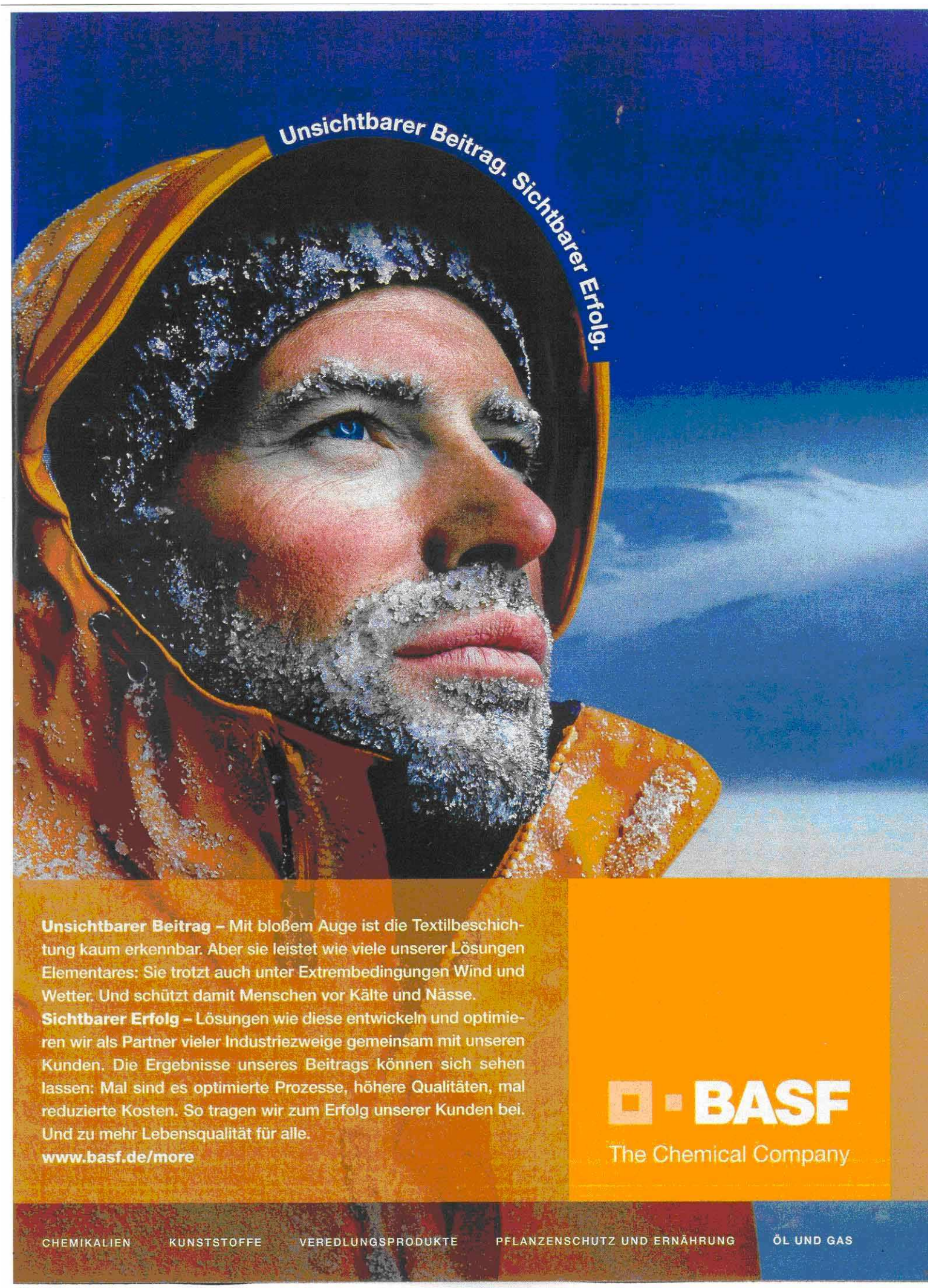


5.1. 1. Anúncio publicado na revista - DER SPIEGEL - 14/02/05 e em outras semanas

Análise da composição visual do anúncio - Foto de um homem de barba e bigode por fazer, trajando capote com capuz e touca, todo salpicado de neve. Ao fundo, aparece uma montanha coberta de neve. O modelo tem o olhar claro, decidido, olhando firmemente para o horizonte, como que buscando o próximo pico a ser alcançado ou o próximo obstáculo. O seu olhar funciona como o vetor, para $\circ$ qual os leitores também deveriam olhar: para o próximo passo, para 0 futuro.

O participante representado encontra-se do lado esquerdo do anúncio. Isso, segundo as regras da sintaxe visual do mundo ocidental é o lado do que é tido como familiar, conhecido e, portanto, serve como ponto de partida para a construção da informação nova. (KRESS; van LEEUWEN, 2001). O novo seria para onde nos leva o vetor do olhar do participante: o próximo obstáculo a ser alcançado. Fica a cargo do leitor imaginar o que o personagem está olhando.

Essa relação também é estimulada pelo fato de a montagem da foto vir sem limite definido, não há moldura. O único limite é o final da própria página, o que provoca a idéia de que o campo de fora da foto faz parte dela. Isso, juntamente com o olhar do personagem, perdido no horizonte, provoca uma leitura 'centrífuga', criando um sentido poderoso de empatia, pois sugere cumplicidade entre o personagem e o leitor, que 'sabem' para onde olham.

Sabe-se que curvas e círculos são destinadas na sintaxe visual, também, a dar a idéia de calor e proteção (DONDIS, 2003) e, como pode ser visto, o rosto do participante permanece dentro de um círculo representado pelo capuz. O texto a ser lido é: embora do lado de fora as condições sejam difíceis, nosso personagem encontra-se protegido, dentro do círculo criado com materiais BASF.

O fundo é predominantemente azul, uma cor considerada fria (DONDIS, 2003), reforçando a idéia do frio no qual se encontra o personagem. Como contraposição a ela, é escolhida a cor amarela para o capuz e o retângulo no qual são colocados o texto e o logotipo, este num tom mais forte. Esses elementos de 
cor são lidos juntamente com as formas analisadas acima. O amarelo, uma cor quente, serve para reforçar a idéia de calor e proteção fornecidos pelo uso de materiais da BASF, ao mesmo tempo em que projetam, em direção ao leitor, o texto e o logotipo e dessa forma os colocam em um contexto de maior modalização e intimidade.

O capuz se abre em ' $V$ ' embaixo do queixo do participante. Este último elemento de seu rosto também representa um ' $V$ '. Os dois ' $V s$ ' agem como uma grande seta dupla que funciona como um vetor indicando o texto lingüístico que se encontra na parte inferior do anúncio, como que chamando a atenção do leitor para o texto que deve ser lido. $\mathrm{O}$ 'V' do queixo aponta diretamente para o primeiro texto e o ' $V$ ' do capuz vai mais além e aponta, também, para os materiais listados abaixo.

Outro vetor interessante é o ' $V$ ' formado pelo nariz do participante, que funciona como uma seta que aponta diretamente para o logotipo. Além disso, esse 'V', tão presente visualmente no anúncio, remete ao gesto de "Vitória"/ "Erfolg" após uma competição ou esforço muito grande. Por intermédio dessas indicações, o olhar humano segue para onde interessa ao anunciante, não só para os textos e para o logotipo que tudo avaliza, como também para um imaginário de experiências de sucesso. Script que é acionado logo no título.

$\mathrm{O}$ anúncio é dividido por meio de linhas que agem como sendo divisórias, não só em esquerda e direita, mas entre 'em cima' e 'embaixo'. Enquanto a parte de cima do anúncio é composta pelo céu e pelas nuvens, o olhar do personagem indica um elemento etéreo ou no futuro, composto também por formas circulares protetoras. A parte de baixo é o racional, algo a ser lido, o logotipo indica que a BASF é real. Isso é colocado imerso em elementos angulares como quadrado e retângulo. Formas exatas que indicam um mundo cristalino, feito por mãos humanas, controlável (DONDIS, ibidem) - no caso desse anúncio, pela BASF. Os produtos nomeados abaixo são a comprovação desse controle.

Ao redor de seus olhos e em seus lábios, rugas, típicas de quem está habituado a lidar com as durezas e desafios da vida, dando-lhe, dessa forma, um aspecto de maior seriedade, tanto pela idade, como pela prática que demonstra 
ter. São acionados scripts de esportes de alto risco, que exigem competência, coragem, determinação. Esportes, principalmente os considerados de alto risco, fazem parte de um campo de 'domínio masculino' (Holly, 2006). A solidão do atleta indica esforço individual, que exige entusiasmo, dedicação, organização e é expressão dessa força de vontade inabalável que consegue superar as forças da natureza. Também segundo o mesmo autor, esse script se sobrepõe, no imaginário alemão, ao script de mundo do trabalho, que é justamente o que vai ser reforçado lingüisticamente no texto abaixo.

Começa a ser criado, nessa narrativa, o cruzamento de vários ethé como: de competência e seriedade. Por isso, a apresentação de um homem de meia idade, e não de um jovem, bem mais comum na prática de esportes radicais. Assim como de ethé de coragem, potência e ousadia a partir da figura de virilidade do personagem, ator de empreitadas arriscadas, capaz de muito trabalho e de mostrar rendimento e sucesso. A composição do anúncio parece corroborar o provérbio: "Wer wagt, gewinnt." ("Quem ousa, ganha".) Essa imagem vai ser vinculada a uma construção discursiva que reafirma tal proposta, com a qual a BASF afirma trabalhar.

Análise da composição lingüística

O exordium - no dizer de Aristóteles -, ou o título do anúncio, é formado com os dizeres:

"Unsichtbarer Beitrag. Sichtbarer Erfolg"./ "Invisível Contribuição. Visível Sucesso."

Este é posicionado sobre a cabeça do personagem como sendo um teto protetor. Esse fator de proteção vai ser reforçado abaixo, no corpo do texto. Ele coloca as primeiras proposições. "A contribuição é invisível. O sucesso é visível". Não se sabe, exatamente, qual é a relação lógica entre as duas proposições, já que sua forma de encadeamento é parataxe. A falta de verbos indica atemporalidade. Isso torna as proposições impossíveis de serem vinculadas a um determinado tempo, dando-lhes uma certa eternidade. 
A figura do uso da recorrência etimológica: unsichtbar, sichtbar - e a mesma estrutura frasal, provocam um paralelismo de construção no enunciado, e ao mesmo tempo usa de antítese para dar uma idéia de paradoxo: é possível ser invisível e visível ao mesmo tempo. O enunciado é elaborado em uma forma curta e ritmada, fácil de ser guardado na memória.

O pelo paralelismo, a cadência ritmada, o uso de expressões atemporais, sem o uso de verbos conjugados, tudo isso torna o título semelhante a um provérbio e pode ser usado de modo a fortalecer uma informação que, teoricamente, já é do conhecimento de todos ou como forma de ensinamento do que já é tido como certo.

Ao mesmo tempo, essas características apontadas acima criam uma certa 'vagueza', pois não se tem idéia de que contribuição ou sucesso se trata, nem de quem contribui ou tem sucesso, ou quando tal sucesso ocorre. O que é próprio da publicidade, pois dessa forma cada leitor pode preencher as lacunas dessa vagueza com suas experiências individuais.

Parafraseando, para melhor perceber relações ocultas, segundo a sugestão de Polenz (1985):

\section{Unsichtbarer Beitrag. Sichtbarer Erfolg.}

1a - "Der Beitrag ist unsichtbar aber der Erfolg ist sichtbar.

(A contribuição é invisível, mas o sucesso visível.)

$1 b$ - Der Beitrag kann nicht gesehen werden aber der Erfolg kann gesehen werden. / (A contribuição não pode ser vista, mas o sucesso pode se visto.)

1c - Den Beitrag kann man nicht sehen aber den Erfolg kann man sehen.

(não se pode ver, mas o sucesso ser pode ver)

Opta-se por preferir na paráfrase o uso do 'aber', que segundo Vogt; Ducrot (1989), não é dependente de uma negação anterior. A BASF não está indo de encontro à afirmação de que a contribuição não pode ser vista, ela concorda e usa isso como algo positivo. Há um índice de polifonia (Ducrot, 1987) que, neste caso, é provocado pela inclusão de outra voz no primeiro enunciado, sugerindo: 'não se pode ver a contribuição da BASF ou a contribuição da BASF 'é pequena'. Isso pode levar a uma conclusão, que a BASF evita, transformando-se em essencial, 
com a introdução do argumento que leva à conclusão desejada com o operador 'aber/mas'. Este operador funciona como um desvio de orientação para uma conclusão diferente do que propunha a primeira proposição (ibidem, 1989). Ao enunciar dessa forma, busca-se uma preservação de face.

Com essa estratégia, os enunciadores se previnem de possíveis opiniões contrárias, funcionando, inclusive, como ethos de sinceridade/honestidade: "Reconhecemos que nossas contribuições não podem ser vistas". Porém isso corre o risco de levar à conclusão de que o anunciante é dispensável. Por isso, a escolha do operador argumentativo 'aber/mas' ao parafrasear. Esse operador reorienta para a conclusão desejada: "o sucesso pode ser visto, graças à nossa contribuição". Isso faz com que esta se torne indispensável“. A BASF proporciona um ganho ao indivíduo mesmo que ele nem perceba. O invisível é capitalizado como algo positivo, imprescindível.

O texto, além de exibir uma função icônica de índice de seriedade, procura também criar sentidos discursivamente, o que, juntamente com a foto, incita no leitor a construção da identidade discursiva que a BASF procura criar para si. Esse cruzamento entre imagem, imagem do texto e sentidos veiculados pelo texto auxilia, logo de início, a criação de um ethos de competência e solidariedade, já que a BASF auxilia o sucesso de quem usa seus produtos.

O título é formado por proposições condensadas (POLENZ: 1985) que podem ser expandidas de acordo com os exemplos 1a, 1b e 1c. Esse processo de condensação de elementos em nominalizações, passivas e grupos nominais acarreta, como já foi discutido na parte teórica, o apagamento de vários itens da proposição - do agente, do tempo verbal, assim como mudança de foco de atenção etc. - o que, muitas vezes, dificulta sua compreensão. O sujeito, neste exemplo, capaz ou não de ver a contribuição e o sucesso, não vale a pena ser mencionado. Essa estrutura de argumentação segue ao longo dos anúncios alemães analisados.

O título que aparece realçado no capuz do homem, reaparece em negrito no corpo do texto, indicando, visualmente, que o corpo textual será reconstruído de forma paralela ao título e, portanto, dividido em duas partes: 
"Unsichtbarer Beitrag - Mit blossem Auge ist die Textilbeschichtung kaum erkennbar. Aber sie leistet wie viele unserer Lösungen Elementares: Sie trotzt auch unter Extrembedingungen Wind und Wetter. Und schützt damit Menschen vor Kälte und Nässe.

"Invisível contribuição - A olho nu, quase não se reconhece a cobertura têxtil. Mas ela desempenha, como muitas de nossas soluções, o elementar: Ela desafia, também em condições extremas, chuva e tempestade. E, com isso, protege os seres humanos do frio e da umidade."

Sichtbarer Erfolg - Lösungen wie diese entwickeln und optimieren wir als Partner vieler Industriezweige gemeinsam mit unseren kunden. Die Ergebnisse unseres Beitrags können sich sehen lassen: mal sind es optimierte Prozesse, höhere Qualitäten, mal reduzierte Kosten. So tragen wir zum Erfolg unserer Kunden bei. Und zu mehr Lebensqualität für alle.

"Sucesso visível - Soluções como estas, nós desenvolvemos e otimizamos como parceiros de muitas indústrias, juntamente com nossos fregueses. Os resultados de nossa contribuição podem ser vistos: às vezes, são processos otimizados, melhores qualidades; às vezes, custos reduzidos. Assim nós contribuímos para o sucesso de nossos fregueses. E para mais qualidade de vida para todos."

\section{BASF}

The Chemical Company

\section{Primeira parte}

'Mit blossem Auge ist die Textilbeschichtung kaum erkennbar.'

Fraseologismo - Mit blossem Auge/a olho nu - evoca frames de tecnologia, ao mesmo tempo em que resgata e reafirma o 'unsichtbar' do título do início desse bloco. Define a insuficiência do olho humano para ver coisas muito pequenas, no caso estudado, justamente para perceber o que importa: a contribuição da BASF. Precisa-se de 'tecnologia, aparelhos', o que pode ser 
traduzido em 'conhecimento, capacidade'. É uma expressão que orienta para a negação de leigos, que vêem o mundo 'apenas com os olhos' e aponta para especialistas que usam equipamentos, ou que percebem e entendem o quanto - 0 que não pode ser visto - é importante. Isso contribui para a criação de um ethos de competência.

Operador - Kaum /Quase não é percebida - que aponta no sentido de orientar para a possibilidade de ser percebida com condições. O uso exclusivo de 'fast/quase' levaria à totalidade da negação: 'fast erkennbar', isto é, 'não é percebida'. E isso não pode acontecer. A BASF quer ser percebida, reconhecida. Por isso, o uso de 'kaum' para amenizar a negação total: - Kaum erkennbar / Quase não (mal) é percebida - aponta para: 'é percebida'. Mas, assegura a percepção por um seleto grupo de especialistas. O 'kaum' volta a apontar para poucos, o que remete ao título: a contribuição dos técnicos é invisível, 'mas' seu efeito determina sucesso. E esse sucesso é parte do inventário perceptual (Randazzo, 1997) com o qual a BASF deseja ser vinculada ao enunciar dessa forma: o ethos de competência e essencialidade. Ela é determinante para o sucesso.

Passiva - quase não é percebida a olho nu - o discurso pleiteado pela BASF ocorre apoiado na esfera discursiva tecnológico-científica (a olho nu e outros termos mais abaixo). Nessa esfera, o que importa são os fatos, não é interessante para a BASF determinar quem não percebe. No caso, os usuários, os não especialistas, justamente os leitores do anúncio. O que interessa é apontar para os que não trabalham a olho nu ou para os que percebem a importância. Isso transparece por meio da escolha da passiva. O agente, o sujeito, é elidido da ação. Reforça-se aí, o ethos de liderança, só para especialistas.

"Aber sie leistet wie viele unserer Lösungen Elementares:"

Operador - Aber/mas - muda a linha de argumentação contida na proposição anterior: 'quase não perceptível, mas...'. Remete o interlocutor novamente ao título - 'invisível, mas/'aber' essencial'. Essencial "como tantos outros" produtos da BASF. Tão essencial que produz o elementar, o básico, os 
fundamentos do produto. Essa é a conclusão a que o enunciado deseja introduzir o leitor com a utilização do operador 'mas'. O 'aber' também é responsável pelo índice de polifonia, dado através da negação do trecho anterior. Como se fosse uma resposta a possíveis discursos que afirmam que a contribuição da BASF não é vista.

Índice lexical de avaliação - Leisten -. De acordo com o dicionário (Götz, 2002, p. 620): 'etwas tun oder fertig machen, das meistens viel Mühe kostet' (realizar ou terminar algo, que na maioria das vezes necessita esforço). O verbo carrega um sentido meliorativo dentro da forma como nossa sociedade ocidental está organizada. Faz parte do frame que é associado a ação, eficiência, a emprego de força ou poder para realizar determinada tarefa. $O$ uso desse termo evoca cognitivamente no leitor todo um comportamento de ação, um script dentro de uma 'Leistungsgesellschaft' ou 'sociedade de performance' na qual vivemos. Nela calcula-se o rendimento das pessoas, o que recebem, o que gastam, o que podem produzir com seu trabalho, seja ele físico ou intelectual, o que valem. A BASF deixa claro que participa dessa construção com seus produtos capazes de (leisten) render muito. Reforço do ethos de competência e poder.

Operador - Wie viele unserer Lösungen/como muitas de nossas soluções comparativo, estabelece relação de igualdade entre os valores. A 'solução' encontrada pela BASF para a Textillbeschichtigung/cobertura têxtil, é só 'mais uma' contribuição entre as 'muitas' que a BASF já produziu. Abaixo está a lista: Chemikalien etc. São 'muitas/viele', tantas que não dá para nomear e que o leitor/consumidor não percebe que existe. E 'wie/como' todas as outras soluções, essa solução também produz o básico, o vital, o 'elementar'.

Nominalização - Elementares - parafraseando: 'Wir leisten viele elementare Lösungen wie die Textil...'/'Produzimos muitas soluções elementares como a cobertura têxtil. Ao ser nominalizado, o termo 'elementar' deixa de ser um atributo de solução para ser o termo para onde aponta todo o enunciado anterior. Eis novamente a BASF produzindo "o essencial, o necessário, o obrigatório, e não apenas contribuições básicas que não são vistas". 
"As nossas" soluções. A inscrição do sujeito no discurso será discutida mais abaixo.

É criada uma tensão na argumentação, sobre o que pode ser o 'elementar', por meio do sinal ortográfico 'dois pontos'. Tensão que é resolvida, logo em seguida, com a utilidade da 'Textilbeschichtigung/cobertura têxtil, que é desafiar condições de tempo extremas, mortais para seres humanos, principalmente para 0 participante representado na figura, que se aventura a escalar montanhas geladas, como a que aparece na foto.

'Sie trotzt auch unter Extrembedingungen Wind und Wetter.

Und schützt damit Menschen vor Kälte und Nässe.'

Operador - Optou-se pelo uso do sinal ortográfico dois pontos ao invés do operador 'denn'/'pois' e, com esse recurso é possível provocar uma tensão maior no texto. Isso prepara o caminho para a introdução da justificativa para a cobertura têxtil ser considerada tão 'fundamental'.

Índice Lexical - Trotzen: 'opor-se a, resistir, desafiar teimosamente (um inimigo, perigo)'. Seinen Trotz zeigen/ jm/etw Widerstand leisten (dem Feind, der Gefahr ) (Langenscheidt, 2002, p. 998). Pelo que se pode perceber o verbo 'trotzen' foi escolhido por invocar o script de ação de audácia, de desafio. Idéia usada com freqüência nos anúncios da BASF na Alemanha.

Efeito de polifonia - 'auch'/'também' - operador que funciona como um efeito polifônico intercalado no enunciado. Que a cobertura desafia chuva e vento, já é dado como fato conhecido. A inserção de 'condições extremas' por intermédio do operador 'também' orienta para a conclusão de dupla proteção. Uma para chuva e tempestade e outra para condições extremas. O que funciona como um reforço, pois 'Wind und Wetter' já aciona o script de condições adversas. O posto é: 'a cobertura têxtil desafia condições adversas'. O pressuposto é: 'a cobertura têxtil desafia chuva e tempestade'. O pressuposto entra no enunciado como imprescindível para que o diálogo continue, pois se alguém duvidar dele o posto não poderá ser aceito (DUCROT, 1987). O posto, no caso, 'unter 
Extrembedingungen'/'condições adversas', entra como um argumento a mais, como que de 'lambuja' por intermédio de 'também'.

Expressões fraseológicas - 'Wind und Wetter'/'chuva e tempestade', 'Kälte und Nässe'/ 'frio e umidade' - Essas expressões também chamam scripts de adversidade, reforçando-se mutuamente, por meio do ritmo que é dado pela figura retórica de aliteração entre 'W, W' e 'ä..ett'. Se cruzarmos essas materializações lingüísticas com a imagem do participante com neve cobrindo o rosto etc., temos os ethé de competência e solidariedade por parte da BASF e da coragem e potência por parte do personagem.

É interessante observar o uso da aliteração no anúncio. '.. kaum erkennbar'; '... trotzt auch unter Extrem ...'; '... sich sehen lassen: mal sind ...' Segundo Mai (2001, p. 10), de acordo com documentos, a primeira forma de rimar, que os falantes de língua alemã usaram, foi a "Stabreim/aliteração". Era usada na arte de fazer versos, que ainda eram fórmulas para benzer doenças. Essa característica, que já pode ser identificada como usual no período da Idade Média, pode ser observada até a atualidade, em muitas de suas expressões fraseológicas. Esse mesmo autor (ibidem, p.10) fornece alguns exemplos: 'Himmel und Hölle'/'céu e inferno', 'Mann und Maus'/'homem e rato', 'Geld und Gut'/'dinheiro e bem'.

Dessa forma, além evocar scripts de adversidade, com o uso de 'Wind und Wetter', 'Kälte und Nässe', evoca-se, também, uma forma de falar que é íntima do leitor alemão e dessa forma procura-se ancorar melhor o texto no espaço mental do consumidor.

Índice lexical de avaliação - Enquanto usa 'trotzen'/'desafio, o anúncio também utiliza 'schützen' (proteger), termos quase antagônicos, mas que se complementam muito bem porque enquanto um termo evoca scripts de coragem e ousadia o outro evoca o de proteção, nesse caso, necessária para o sucesso. Tem-se o desafio das causas no par 'vento e tempo', e a proteção quanto às conseqüências no par 'frio e umidade'. Existe um equilíbrio entre a capacidade de reconhecer e ousar aproveitar a chance, o que exige capacidade de empreendimento e ousadia, mas com o 'fornecimento/Leistung' de toda a 
segurança (proteção que seja necessária para o sucesso). Um sem o outro não forneceria 0 ethos de seriedade. $O$ fornecimento da proteção necessária fica por conta da BASF. A ousadia, por conta do herói.

Operador - 'und' - de conjunção, se encarrega de encadear a classe argumentativa (DUCROT, 1987), na qual os argumentos, como uma lista de qualidades estão orientados para a mesma conclusão: as vantagens fornecidas pela BASF. A 'cobertura protetora' está numa relação metonímica para a BASF. Isso visualmente pode ser percebido no capuz que forma o círculo protetor do usuário

-sie trotzt Wind

-sie trotzt Wetter

-sie trotzt auch unter Extrembedingungen

-sie schützt vor Kälte

-sie schützt vor Nässe.

Já ancorado no ethos de competência e essencialidade, procura agregar o ethos de coragem, demonstrando ousadia desafiadora de condições adversas e uma BASF responsável pelo sucesso com segurança, um ethos de solidariedade.

A estrutura da argumentação, feita nessa primeira parte do anúncio, pode ser esboçada da seguinte maneira:

- Unsichtbar - blossem Auge (nur - negativo no sentido de exclusão), kaum (negativo - excluindo), aber (inversão do argumento mudando conclusão), leistet Elementares (motivo, justificativa para mudança da conclusão), denn (substituído por dois pontos), trotzt (motivo), schützen ( motivo adicional, um plus).

\section{$\underline{\text { Segunda parte }}$}

Sichtbarer Erfolg - Lösungen wie diese entwickeln und optimieren wir als Partner vieler Industriezweige gemeinsam mit unseren kunden. Die Ergebnisse unseres Beitrags können sich sehen lassen: mal sind es optimierte Prozesse, höhere Qualitäten, mal reduzierte Kosten. So tragen wir zum Erfolg unserer Kunden bei. 
Und zu mehr Lebensqualität für alle.

"Lösungen wie diese entwickeln und optimieren wir als Partner vieler Industriezweige gemeinsam mit unseren Kunden."

\section{Operador - classe argumentativa}

1- - Lösungen ( soluções: implica existência de problemas)

- Entwickeln wir / desenvolvemos

- 'und'

- optimieren wir / otimizamos

- Als / Como Partner - coloca-se como companheiro tanto de fregueses como de indústrias. Será que em igualdade de condições?

- De muitas indústrias

De nossos fregueses.

Inversão - O enunciado considerado sem termos marcados, em relação à colocação dos termos pedidos pela valência do verbo e de seus complementos, seria, como afirma Polenz (1985, p. 292), "Suj + Verb + Objekt". O autor acrescenta que "a língua alemã, nesse aspecto, em comparação com inglês, francês e latim é um tanto livre", já que, como se sabe, os lugares antes ou depois do verbo finito podem ser trocados. Uma inversão nessa ordem de colocações entre os termos, porém, não ocorre sem provocar a mudança do que se deseja realçar na proposição (ibidem).

No termo 'Lösungen wie diese', o acusativo é tirado de seu lugar que seria no enunciado não marcado, após o verbo, e trazido para o início do enunciado, passando a ser um termo marcado, o que se traduz numa acentuação, realce, do que a BASF faz. Da mesma forma, esse procedimento marca o 'nós', ao ser transferido para junto dos parceiros com os quais a BASF diz trabalhar. É como se ficasse: Lösungen wie diese entwickeln und optimieren wir als Partner vieler Industriezweige gemeinsam mit unseren Kunden'. ,Soluções como essas, nós desenvolvemos e otimizamos como parceiros...' Mesmo que outros sejam colocados 'como parceiros' o 'nós' sobressai. 
Operador - Lösungen wie diese/como estas' - novamente estabelecendo relação de igualdade com muitas soluções e retomando o que foi dito acima com 'wie viele unserer Lösungen'. Essa é a segunda vez em que o termo aparece, junto com a idéia de que a BASF é responsável por muitas soluções.

Operador - und - de conjunção, ligando os dois argumentos em relação às atividades exercidas pela BASF.

Linguagem comodificada - optimieren/otimizar e entwickeln/desenvolver' - dois itens lexicais que funcionam como índices de avaliação positiva. O termo 'optimieren' pode ser considerado como sendo um exemplo de 'linguagem comodificada'. Usa-se preferencialmente um termo com mais prestígio junto à comunidade. Aparentemente, esse termo está muito em moda na moderna forma de falar sobre relações de produção, implica baixo custo e alta produtividade, o que de forma alguma é uma nova maneira de relacionamento entre o capital e o trabalho. Esse último verbo aparece duas vezes. Na segunda vez, como particípio transformado em atributo.

Palavra de plástico - O termo 'entwickeln' é um dos citados por Pörksen na lista de 'palavras de plástico': palavras amorfas que se amoldam em contexto de usos abrangentes demais e, portanto, "ao falante, falta o poder de definição destas" (PÖRKSEN, 1988, p. 118) ${ }^{26}$. O termo 'optimieren' pode ser colocado nesse mesmo patamar. Ambos têm um espectro de significação tão amplo que se diluem em seu poder de definição, porém somente após acionar scripts claramente positivos de competência tecnológica e econômica. Fornece à BASF um ethos de credibilidade e seriedade por ela mostrar tanto empenho em arranjar soluções para problemas. Sim, porque "encontrar soluções" implica a existência de problemas, sobre os quais não se fala diretamente. Apenas mostrados na foto e indicados como sendo desafios a serem vencidos ousadamente.

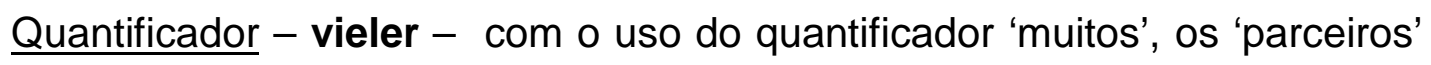
são minorados em valor, pois são muitos. Ao mesmo tempo, a importância da BASF é realçada, já que ela afirma ter tantos parceiros.

\footnotetext{
26 "Die Wörter werden nicht in den jeweiligen Zusammenhängen nuanciert und festgelegt; dem Sprecher fehlt die Definitionsmacht".
} 
É interessante notar como o anúncio, cuidadosamente, coloca os termos em ordem decrescente 'nós - a BASF $>$ os parceiros $>$ os fregueses $>$ todos. Embora use termos que indiquem uma certa igualdade como: 'partner' para outras indústrias e 'gemeinsam /conjuntamente' para os fregueses, o anúncio não deixa de colocar claramente cada elemento em seu devido lugar na ordem decrescente de importância. Em primeiro lugar, na liderança a BASF/wir, depois os que trabalham quase no mesmo patamar, depois os que têm o sucesso com isso, e por fim todos os outros, os que só aparecem no final como sendo os beneficiários porque a BASF trabalha solidariamente.

Contribui para a manutenção do ethos de competência (Lösungen, entwickeln, optimieren), solidariedade (Partner, Kunden) e liderança (wir colocado da forma como está)

Die Ergebnisse unseres Beitrags können sich sehen lassen:" Os resultados de nossa contribuição podem ser vistos.

Índice de polifonia - existem vários pressupostos:

Posto: algo pode ser visto.

Pressupostos: 1- A BASF contribui; 2- essa contribuição 'já' forneceu resultados; 3- existem vários resultados. 4- os resultados foram positivos.

Há a possibilidade de várias discordâncias quanto a esse enunciado: 1- não existe contribuição da BASF; 2- a contribuição da BASF não deu resultados; 3não deu vários resultados, só deu um; 4- os resultados não foram positivos; 5- os resultados não podem ser vistos. Nessa montagem argumentativa, o leitor recebe como sendo um bloco com várias informações. Além disso, são diferentes ações que viram processos por meio de nominalizações, nas quais os agentes da ativa desaparecem e que nos chegam com um grupo nominal, difícil de ser questionado, por parecer um processo já estabelecido e sobre o qual todos já têm conhecimento.

Fraseologismo - ... können sich sehen lassen/pode ser visto - é uma expressão fraseológica e indica que 'algo visto causa boa impressão', portanto evoca frames positivos a respeito do que vai ser ligado a ela: os 'resultados da 
contribuição'. É coerente com o campo semântico que vem sendo usado desde o título e mantém o jogo aí proposto entre 'unsichtbar' - mit blossem Auge, erkennbar - e 'sichtbar' - kann sich sehen lassen. O uso dessa expressão realça o grupo nominal a ele ligado e provoca um apagamento dos indivíduos que de fato possam perceber os resultados, isto é, os consumidores dos produtos da BASF. O que deve ser realçado é a atividade da BASF por meio da inserção do pronome possessivo 'nosso', fazendo com que a inscrição da BASF, enquanto criadora desse discurso sobre 'soluções e contribuições', fique bem clara. $O$ que deve parecer importante para os leitores do anúncio é o resultado do que a BASF faz para e pelos consumidores e não o que estes fazem em relação à BASF. De qualquer forma, os consumidores não podem ver, pois as "contribuições são invisíveis". Apenas os especialistas podem ver.

"Die Ergebnisse unseres Beitrags können sich sehen lassen" - "Os resultados que podem ser vistos" surgem com outra classe argumentativa:

mal sind es optimierte Prozesse, höhere Qualitäten, mal reduzierte Kosten.

Mal sind:

- optimierte Prozesse/processos otimizados;

- höheren Qualität/ melhor (mais alta) qualidade;

Mal

- reduzierte Kosten/ custos reduzidos.

Operador - Mal...mal.../ às vezes... às vezes - poderia ser entendido como os operadores de disjunção, porém inclusivos. (Polenz, 1985, Koch, 1996) Não se está aí definindo a exclusão de um em função do outro, mas a possibilidade de ocorrerem ambos. Esse operador liga os dois argumentos apresentados, dirigindo a conclusão para o mesmo sentido. Esta conclusão é resumida com o 'so/portanto' que inicia o enunciado seguinte.

Índice de avaliação - optmiert, höher, Qualität, reduzierte Kosten processos otimizados, alta qualidade, custos reduzidos. A tríade perfeita do capitalismo eficiente e moderno: economia de tempo, ganho em qualidade e a preços vantajosos. Essa composição de termos aciona o frame de uma atividade 
econômica bem sucedida, moderna e de liderança, pois o uso do comparativo 'höher/mais alto' indica que, na hierarquia das indústrias, a BASF está no mais alto patamar. Reforçam-se os ethé de competência e liderança.

"So tragen wir zum Erfolg unserer Kunden bei. Und zu mehr Lebensqualität für alle."

Operador - So/dessa forma - "operador encadeador do tipo conclusivo", usado para introduzir a conseqüência do exposto anteriormente, levando à conclusão (POLENZ, 1985, p. 279). É ideal para arrematar o operador 'classe argumentativa', usado ao longo da segunda parte do anúncio. Introduz a conclusão relativa ao raciocínio exposto anteriormente. A conclusão também ocorre por uma classe argumentativa ligada pelo operador de conjunção 'und'.

Operador - und/e - soma os argumentos que se dirigem na mesma direção, reforçando a conclusão (Polenz,1985, p. 269).

- Para o sucesso (de quem é vinculado à BASF)

- Para mais qualidade de vida para todos.

Índice de Avaliação - O termo usado no título 'Beitrag/contribuição', que já foi acionado até aqui três vezes, volta a ser resgatado, agora como uma ação: 'beitragen', cuja posição de agente é assumida pela BASF. Fica, mais uma vez, claro que a contribuição é uma ação da BASF que possibilita o sucesso 'otimizado' do freguês.

Quantificador - alle/todos - orientado no sentido de afirmação plena. Não há possibilidade de exclusão. O sucesso é dos fregueses, proporcionado pela BASF, mas o que é considerado invisível, no início do anúncio (a melhoria da qualidade de vida) é de todos, de toda a sociedade. A BASF torna-se quase onipotente.

Índice de polifonia - mehr/mais - segundo o anúncio, a BASF contribui para 'mais' qualidade. Não é que não se tenha qualidade, afinal a BASF já desenvolveu vários produtos, essas não são as únicas soluções, outras já ocorreram. 'Mais' qualidade, indica na direção de uma progressão de qualidade, não se pretende parar por aí. Há nesse 'para mais' um índice de polifonia 
(DUCROT, 1987). Faz parte dos pressupostos adverbiais, citado por Koch (1996:73) como: "mesmo, ainda, já, pelo menos etc." A BASF já contribui, e sempre, e cada vez mais.

Seleção Lexical - Lösungen/soluções e Ergebnisse/resultados - são termos definitivos. Não admitem questionamentos. Os problemas, sejam quais forem eles, já estão resolvidos. Já foram encontradas as soluções e os resultados positivos já foram obtidos. São termos que acionam frames com carga de positividade muito acentuada. Assim como os termos: 'desenvolvemos e otimizamos', todos sinalizam, para scripts que indicam a melhora de algo. Embora o termo 'desenvolvimento' possa ser neutro, raramente é usado no sentido negativo, a não ser quando se fala no desenvolvimento de uma doença, na área médica. O grau de positividade destes termos será reforçado abaixo com: processos otimizados, alta qualidade, custos reduzidos.

Palavras de plástico - as palavras acima citadas fazem parte do grupo descrito por Pörksen (1996). Termos que foram tomados pelas ciências, modificados, e devolvidos ao uso cotidiano. Retornam a esse uso diário, com mais respeitabilidade. Os termos 'processo, qualidade, progresso, desenvolvimento...' são dados como exemplos por Pörksen (1996, p. 14) para esse tipo de palavra. Usadas conjuntamente, não deixam margem a questionamentos a respeito de que tipo de soluções ou resultados o anúncio trata. São positivos.

As palavras 'processo' e 'qualidade' aparecem no anúncio, o termo 'desenvolvimento' aparece como verbo: 'Wir entwickeln'. Elas passam despercebidas por parecerem objetivas e densas em seus significados, mas como afirma Pörksen (1988, p. 61), "justamente por isso desenvolvem seu efeito

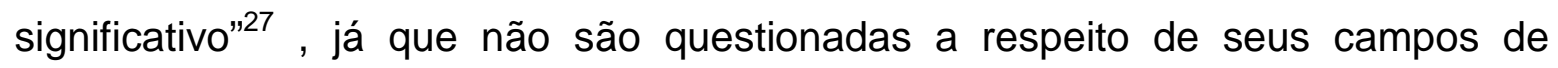
referência. Evocam frames positivos de cientificidade, de competência econômica, cuidado com a comunidade a que servem e dessa forma remetem aos leitores ethé de credibilidade, liderança e solidariedade no momento em que se apresentam tão interessados na melhoria da qualidade de vida de todos.

27 “... und entfalten grade dadurch ihre unheimliche Wirkung”. 
Modalização - nesse caso a modalização é feita pela própria seleção dos termos meliorativos, que se reforçam entre si.

Outro fator de modalização são os enunciados sempre na afirmativa, indicando a certeza e o comprometimento do falante em relação ao seu discurso. A realidade criada pela BASF é absoluta. Não deixa espaço para possíveis modalizações de dubiedade. É uma maneira de modalização que reforça a crença sobre o conhecimento assegurado como certo, real. Não se trabalha com negações, apenas afirmações que falam de resultados, como processos já finalizados de maneira positiva. E essa é a função da publicidade, fazer o recorte da realidade que se deseja apresentar como sendo a única possível.

Inscrição do sujeito

- wie viele 'unserer' Lösungen

- entwickeln' wir'

- optimiren 'wir'

- mit 'unseren' Kunden

- 'unseres' beitrags

- so tragen 'wir'

- 'unserer' Kunden

- logotipo - ('wir') BASF

O referente sobre o qual a primeira parte do anúncio é construída é a cobertura têxtil. Na segunda parte, esse referente é retomado e expandido para as soluções e contribuições da BASF. Mas todos os referentes fazem parte de um processo metonímico para falar da BASF, o verdadeiro referente.

É construído um locutor que se manifesta sempre explicitamente na forma pronominal 'nós' ou por meio de seus possessivos e terminações verbais correspondentes: nós desenvolvemos, nós otimizamos, nós contribuímos, portanto, a BASF toma para si o discurso e fala sobre si própria em primeira pessoa. Em nenhum momento, há dúvidas sobre quem assume ser o sujeito desse discurso.

É um 'nós' monolítico, sem possibilidades de a BASF aparecer como dividindo o espaço com o outro possível locutor, no caso, a agência de anúncios 
que poderia ter escolhido outra forma de falar sobre o referente, isto é, falar sobre a BASF como sendo um referente, em terceira pessoa. Como foi a opção do anunciante no Brasil. Nesse 'nós' monolítico a BASF se mostra onipotente, 'desenvolvendo, solucionando, contribuindo para o sucesso dos companheiros, fregueses e bem-estar de todos'.

É um 'nós corporativo', inclui todos os que fazem a BASF: os presidentes, os operários, os engenheiros, os acionistas. Muito de acordo com a comodificação da linguagem, que tenta tratar a todos os integrantes de uma instituição como sendo parte de uma mesma família. Tenta-se, dessa forma, construir a idéia de que as hierarquias são apagadas em nome do beneficio de todos e de que todos estão nas mesmas condições, trabalhando pelo sucesso de si próprio, dos fregueses e pelo bem de todos. Um 'nós' alienante, já que provoca a sensação de pertencimento que não é real, pois nem todos podem ter voz e defender-se da mesma forma por ocasião de grandes demissões.

Esse 'nós' inclui também os parceiros e os fregueses, por intermédio do pronome 'nosso'. Não aparecem como em igualdade de condições, como foi discutido acima, mas como fazendo parte do mesmo grupo liderado pela BASF. Esses sentidos levam à criação dos ethos de liderança, mas ao mesmo tempo de um ethos de solidariedade, pois são considerados mais ou menos como estando em níveis semelhantes.

Não se encontra um interlocutor específico na forma 'você' ou seu plural que esteja explicitamente representado no texto. Há, sempre, a recorrência ao indefinido 'es/se', que é um índice de indefinição do sujeito. O anúncio traz o sucesso como receptor imediato das contribuições, de todos os esforços feitos pela BASF e o Kunde/freguês passa a ser o atributo genitivo de sucesso. Afinal, o sucesso para todos perde o sentido numa sociedade competitiva. O sucesso não é extensivo a todos. Os fregueses podem até ser ativos nos empreendimentos, na audácia, mas quanto aos resultados obtidos, isto é, o sucesso, estes não seriam possíveis sem a presença da BASF, o ethos de liderança com solidariedade fica demarcado. 
É incluído no final: 'Und zu mehr Lebensqualität für alle/ para mais qualidade de vida para todos'. A melhor qualidade de vida é extensiva a todos. Afinal, a BASF não deve se mostrar mesquinha. Desse modo, todos são trazidos para dentro do seu discurso de onipotência. Todos são seus beneficiários, saibam ou não disso. O que retoma o início do texto: 'A olho nu não é possível perceber'. Esse modo de uso continua a reforçar o ethos de solidariedade, onde a BASF se mostra contribuidora, de maneira definitiva, do bem-estar da comunidade.

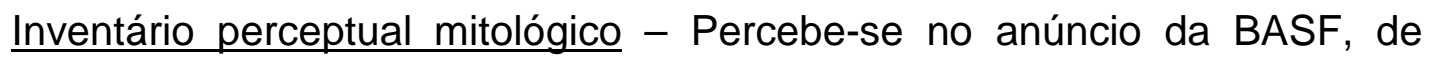
acordo com o levantamento dos termos lingüísticos, o seguinte: sucesso, condições extremas, soluções (inteligentes e eficazes para essas e outras condições), juntamente com o reforço da imagem do personagem da narrativa, que aparece exposto justamente a situações de limite, que requerem ousadia, coragem, inteligência, potência, persistência etc. De posse desses elementos, pode-se deduzir que a BASF procura criar um inventário perceptual baseado no arquétipo do herói. O herói do tipo másculo, de olhos límpidos, com o desejo honesto, claramente estampado no rosto, sem subterfúgios, puro, cercado por uma aura reluzente que pretende fornecer-lhe um status acima dos comuns mortais. Busca, dessa forma, criar para os interlocutores um papel no qual podemse espelhar e identificar-se com esse papel do herói conquistador, indivíduo ousado, empreendedor.

De acordo com o que foi exposto na parte teórica deste trabalho, esse tipo de herói é sempre solitário, conta apenas com sua coragem para a resolução de problemas. Essa solidão é acentuada nas narrativas publicitárias dos anúncios alemães da BASF. Porém, como se afirma várias vezes no anúncio, ele conta com a BASF, que está sempre presente, mesmo que não seja vista, ela protege o herói contra tudo que possa impedi-lo de conquistar o sucesso.

Com a materialização, na superfície lingüística, dos termos: 'schützen vor/proteger de', 'Elementares leisten/fornecer o essencial', 'Wir entwickeln, Wir optimieren/nós desenvolvemos, otimizamos', a BASF se coloca nesta construção argumentativa como a figura do 'mentor'. Essa figura pode assumir vários 
aspectos nas narrativas arquetípicas. Pode ser um ancião ou uma anciã sábia, uma bruxa ou bruxo, um pai sábio, um animal mágico e outras possibilidades. É aquela figura necessária ao herói para que este obtenha sucesso. Ela fornece o amuleto, o segredo esotérico, o dom mágico, a força, o conhecimento, enfim, o diferencial que faz com que o herói tenha sucesso em sua empreitada. No caso, a BASF fornece a tecnologia de ponta. Este é o "elemento mágico", que, à maneira das forças que auferem poderes mágicos ao herói, não pode ser visto a olho nu = "unsichtbarer Beitrag". É esse conhecimento oculto da BASF que viabiliza o sucesso do herói, do freguês, dos parceiros.

Uma das características do herói é que, ao terminar sua empreitada, deve retornar à comunidade com a 'boa nova', com a solução do problema que a colocava em risco e dessa forma levar o bem-estar a todos. Esse é justamente o slogan expandido criado pela BASF: 'Und zu mehr Lebensqualität für alle./ E para mais qualidade de vida para todos.'

Além de compor, no inventário perceptual, a característica do mentor protetor do herói, a BASF também cria, para si, nos anúncios alemães, componentes característicos do mito do Grande Pai. Esse é o arquétipo do pai que ama condicionalmente, do pai que exige que seu filho seja o portador da fama advinda de grandes feitos. A característica desse pai arquetípico é a exigência de que seu filho faça jus ao seu amor. É um amor condicionado à admiração. Este arquétipo não se confunde com o da Grande Mãe, que é o arquétipo responsável por representar a idéia de alguém que mantém acesa a lareira, o fogo em torno do qual permanece coesa a estrutura protetora familiar, na eterna paz, que tem como símbolo o círculo, fechado, impenetrável aos perigos. No arcabouço arquetípico ela, a Grande Mãe, se propõe a proteger seus filhos em quaisquer circunstâncias, mesmo sendo fracos e não dados a grandes aventuras. A grande mãe ama/protege/ajuda/alimenta incondicionalmente os seus filhos, que podem assumir atitudes passivas nessa relação amorosa, em que só ela tem a tarefa de amar incondicionalmente. $O$ arquétipo do Grande Pai é o de ser par complementar, imprescindível para manter a comunidade em equilíbrio. Este exige 
de seus filhos Leistung/rendimento, Lösungen/soluções, Trotz/obstinação e principalmente Erfolg/sucesso.

A BASF alemã se liga no inventário perceptual criado no seu anúncio a um arquétipo que busca estimular seus leitores a grandes e ousados atos que levem a conquistas e à admiração de todos.

No caso acima, a conclusão a que nos dirige o anúncio é: a BASF, com seus produtos essenciais, estimula o ser humano a ser audacioso, empreendedor, vencedor de obstáculos. Aparentemente, a própria empresa propõe tais façanhas ao mesmo tempo em que fornece a proteção necessária para sua execução, o que é traduzido como contribuições essenciais que não podem ser vistas por nãoiniciados, capacidade delegada apenas aos especialistas.

Essas características não estão separadas entre BASF e leitores. No anúncio, elas se encontram amalgamadas. Essa ambigüidade é útil para que os leitores se identifiquem com o herói e a BASF ao mesmo tempo, afinal um é o outro. O herói não é possível sem a BASF e a BASF não tem sentido sem o herói.

\section{Conclusão parcial}

O que se pode perceber pela estratégia argumentativa do texto, já discutida como uma junção de elementos lingüísticos e visuais, é que a BASF constrói para si uma identidade que ressalta, principalmente, os ethé de liderança e poder: Entwickeln und otimisieren wir als Partner / Erfolg/sucesso; competência tecnológica por intermédio de vanguarda em pesquisas, (Performancematerialien, Veredlungsprodukte/ produtos de performance), assim como os éthe de credibilidade e solidariedade (Lebensqualität für alle, Partner).

Existe, também, ethos de sinceridade, por parte da BASF, pois esta reconhece que seus produtos não são vistos, mas transforma e capitaliza isso, que poderia parecer negativo, em algo positivo, como uma espécie de amuleto esotérico de um mentor mitológico, que só pode ser percebido por iniciados e que, verdadeiramente, possibilita o sucesso para quem tem coragem de buscá-lo. Por isso a importância do uso do operador adversativo 'aber/mas' que, se aparece 
omitido no título, aparece claramente no texto: 'Aber sie leistet....: Elementares./Mas fornece... o essencial.

Para o leitor, o anúncio constrói, a partir do personagem da narrativa, uma identidade com um ethos claro de potência (indivíduo, forte, viril, capaz de coragem e ousadia empreendedorística, apesar de solitário). Os ethé de poder por parte da BASF e de potência se complementam. O ethos de poder construído pela BASF para mostrar sua capacidade de contribuir e organizar o bem-estar de todos é reforçado pelo ethos de potência da figura viril do herói que vai exercer sua vontade obstinada e imbatível de chegar aos picos mais altos, quem sabe, o Olimpo. Busca-se criar, também, um ethos de inteligência, já que o leitor deve se identificar com alguém que é capaz de perceber o que deve ser usado em situações difíceis como a representada e, portanto, confiar no 'mentor' correto.

A imagem é estimuladora. É como se a BASF estivesse incitando os leitores a tais situações e, ao mesmo tempo, protetoramente, assumindo um papel de mentor, fornecendo a defesa, a segurança. Sugere que quando o indivíduo se encontra nesse tipo de situação, é que mais precisa de competência e tecnologia fidedignas. E para isso existe a BASF. Por isso o elemento lingüístico sempre recorre a termos que evocam termos de avaliação positivos: como Ergebnisse/resultados, Lösungen/soluções, leisten/fornecer rendimento, schützen/proteger, além de fraseologismos que brincam com o tema do título invisível/visível: 'mit blossem Auge/a olho nu', können sich sehen lassen/podem ser vistos', kaum erkennbar/quase não se vê.

Ao construir esse tipo de inventário para o anúncio, opta-se por acionar elementos mitológicos que trazem o papel do herói conquistador, corajoso, desbravador e solitário, sempre vencendo desafios menos ou mais perigosos, que não apresenta desejos de acomodação. A recorrência ao uso desse tipo de herói será encontrada nos outros anúncios alemães analisados.

Toda a narrativa publicitária é montada de forma a construir-se a possibilidade de falar sobre a importância da BASF em momentos de necessidade de grande rendimento. Esse conjunto de características ligadas aos ethé, à situação narrativa, às imagens lingüísticas com que isso é expresso, permite que 
formações discursivas referentes a esses campos de atividades surjam sem que seja necessário explicar de onde vêm.

Dessa forma, entram em ação os acordos sobre os quais estão montadas as sociedades e ocorre a busca por pretensões de validade, isto é, o leitor tenta dar sentidos aos elementos que vê na narrativa publicitária. São acionados scripts de esportes de inverno, que contêm elementos como neve, frio, umidade, ventania, alto rendimento, esforço, situações perigosas etc., de forma que o leitor chegue à conclusão da importância da BASF em momentos difíceis como esses. Para isso, tem-se a imagem e o material lingüístico: unsere Lösungen, Elementares, Extrembedingungen trotzen, Menschen schützen vor etc. e a articulação dessas duas linguagens para a conclusão de que a BASF é onipresente, pois está onde não se vê e é vital para o sucesso nas atividades humanas.

A foto e o texto lingüístico não são, definitivamente, simples traduções um do outro, eles se complementam para produzir sentidos mais ricos e, dessa forma, potencializam os efeitos desejados pelo anúncio, aumentando sua capacidade argumentativa e afetiva para se ligar à mente do leitor.

Em função de sempre falar "nós", a BASF, nesse anúncio, se coloca como dona, senhora de seu discurso e tem a intenção de deixar isso bem claro. Não fala de si própria como se fosse "sobre ela", uma terceira pessoa distante. Tal artifício reforça uma identificação com o leitor. Surge como: "somos nós, a BASF, que estamos falando, que estamos tão presentes na sua vida, apesar de, na maioria das vezes você nem perceber". Quem sobra, na Alemanha, que não está dentro desse discurso? Ninguém, pois no final a qualidade de vida é extensiva a 'todos', mesmo que eles não vejam/percebam.

A inclusão do leitor neste "nós monolítico" da BASF fica perceptível quando se nota que não há um interlocutor claro ao qual o anúncio se dirige. A BASF não se dirige a um "tu" específico, o que faz com que todos se sintam incluídos, já que não há espaço no discurso para a inserção do leitor, que não seja fazer parte da BASF. 
Usam-se de palavras de plástico, que indicam um elevado índice de valoração positiva: entwickeln/desenvolver, Qualtitäten, Prozesse. Incluímos nesse item optimieren/otimizar. Essas palavras acionam scripts de situações positivas de competência, trabalho, dedicação, solidariedade em termos de custo = reduzierte Kosten. Com isso, cria-se o inventário perceptual de uma empresa com a qual o consumidor pode contar em todos os momentos, bons e ruins, como se fossem elementos que fizessem parte da natureza. Assim como fazem parte da natureza os elementos atmosféricos postos em cena. 


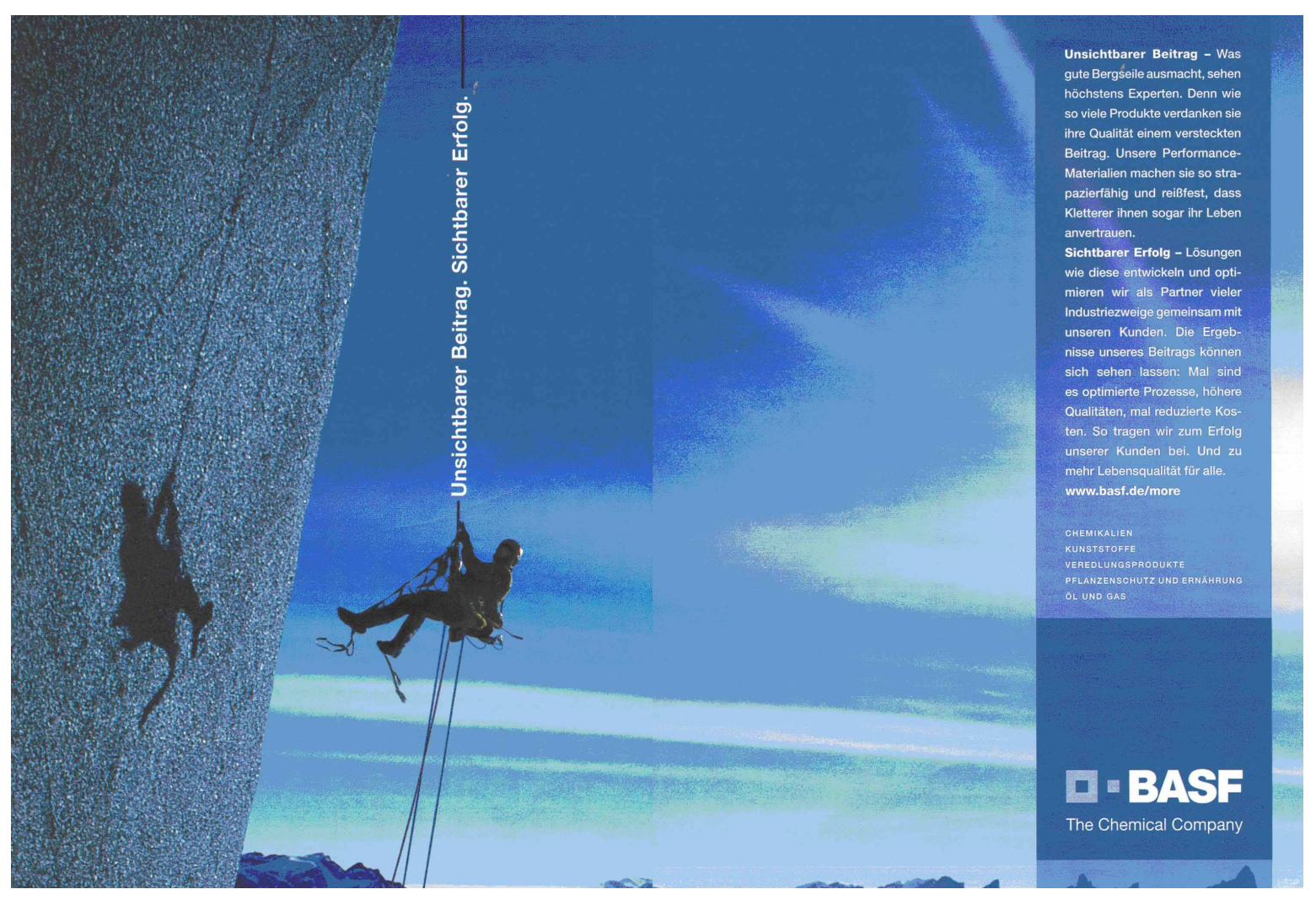




\subsection{Anúncio publicado na revista - DER SPIEGEL - de 31/10/05 e 17/10/05 e em outras}

Análise da composição visual do anúncio - Foto dramática. Um homem dependurado numa corda na encosta de uma pedra, completamente dependente da resistência dessa mesma corda, para se manter com vida.

O anúncio é em tons de azul mesclado com branco brilhante. A corda que sustenta o homem lembra um cordão umbilical que passa pelo abdome do personagem. Ela faz uma ligação entre a terra e o céu não se podendo ver suas extremidades. Isso provoca o efeito de uma leitura centrífuga da imagem, estimulando o leitor a imaginar o que está fora do campo da foto, acima e abaixo. O título do anúncio ocupa, estrategicamente, um trecho que seria ocupado pela corda, como se estivesse sustentando o homem, suspenso no ar: "Unsichtbarer Beitrag. Sichtbarer Erfolg."

A linha formada pela corda funciona como a ligação entre o céu e a terra. $O$ herói encontra-se em um estado intermediário, no caminho de baixo para cima (do terreno para o paraíso?). À sua frente, projeta-se sua sombra, que mais parece um lagarto subindo pela encosta da pedra, com se estivesse caminhando da pedra escura e dura em direção ao firmamento etéreo e luminoso em direção á claridade total, representada pela BASF. A mensagem que chega ao leitor, novamente, é: "Wer wagt, gewinnt" (quem ousa, ganha). 'Você pode' chegar ao alto, vencer obstáculos etc. (com a ajuda invisível da BASF, naturalmente).

No lado esquerdo do anúncio, vemos um trecho da encosta da montanha a ser escalada. Ela funciona como uma moldura que encaminha nosso olhar para a leitura do texto que substitui um trecho da corda. Na rocha, projeta-se uma sombra que, ao contrário do personagem, solto no ar, parece estar 'presa' ali, como um desenho, uma 'tatuagem'. Mas ao mesmo tempo, parece estar fazendo um trabalho imenso para libertar-se e conseguir subir. A linha que indica o término da pedra faz a primeira das três divisões verticais do anúncio. Em oposição a ela, temos o personagem, que está flutuando, pendurado pela corda, parecendo desafiar a lei da gravidade e já liberto da pedra (graças aos produtos da BASF). A 
corda pela qual está suspenso o participante funciona como a segunda divisão vertical do anúncio. A terceira divisão é a caixa onde se encontram os textos lingüísticos.

Pelo caminhar natural de nosso olhar ocidental - da esquerda para a direita e de cima para baixo -, seguimos um caminho de luz que se choca com a rocha, e faz a ligação da sombra com o personagem e deste com o logotipo BASF e o slogan "The Chemical Company". Essa linha é o vetor que nos indica para onde dirigir o olhar, a saber, o logotipo. Ela conecta esses participantes representados: a sombra, o indivíduo suspenso e o logotipo, indicando que todos estão envolvidos em 'algo' que parece ser a história dos estágios da humanidade: primeiro a idade da pedra, depois a modernidade, com o ser humano solto em um espaço de inseguranças, sem grandes apoios, exceto seu cordão umbilical (a corda) e finalmente o paraíso, pelo qual a BASF é responsável, no final do anúncio. Essa linha também cria uma divisão horizontal do anúncio. Abaixo dela está o mundo terreno, 'real', com seus mares e montanhas, e acima, um mundo a ser conquistado, a superação dos limites.

Acima do vetor mais expressivo - o feixe de luz que une a sombra, o personagem e a logomarca -, há outros, também em forma de luz, bem visíveis, porém, menos acentuados. Um, mais forte, que indica para os materiais produzidos pela BASF, e dois vetores menores, que apontam para as outras partes do texto e que formam uma seta. Dessa forma, o texto visual e o lingüístico são unidos claramente. Como essa composição só tem uma moldura do lado esquerdo - a rocha -, nosso olhar, conduzido pelos vetores, segue para a direita, e a partir daí para o foco de luz, que se posiciona quase fora do anúncio. Esse jogo de vetores, por sua vez, provoca uma leitura centrífuga, pois conduz o olhar do leitor para um ponto bem definido, que é o texto e depois para fora.

Continua a indução ao cruzamento dos mesmos ethé: tanto para a BASF fidedignidade pela competência -, quanto para o participante da narrativa coragem, potência e muita persistência nos seus objetivos ousados. O domínio do mundo masculino continua reinando absoluto, com sua capacidade de contornar as forças da natureza. 
Análise da composição lingüística - Será analisada aqui apenas a primeira parte do corpo do texto, que é o que o diferencia do anúncio anterior. Essa repetição da forma como os textos são organizados, de trechos, de componentes da imagem, assim como do tema escolhido indicam uma forte intertextualidade entre os anúncios e faz com que as propagandas da BASF sejam imediatamente reconhecidas, sem exigir muita atenção do leitor. Parece um cânone a ser repetido para ser memorizado, o que é uma das estratégias mais usadas em publicidade. O próprio slogan é prova disso.

"Unsichtbarer Beitrag - Was gute Bergseile ausmacht, sehen höchstens Experten. Denn wie so viele Produkte verdanken sie ihre Qualität einem versteckten Beitrag. Unsere Performancematerialien machen sie so strapazierfähig und reissfest, dass Kletterer ihnen sogar ihr Leben anvertrauen."

"Contribuição invisível - O que importa para um bom alpinismo, no máximo os especialistas percebem, (só mesmo os especialistas vêem), pois, como tantos outros produtos, eles devem sua qualidade a uma contribuição oculta. Nossos produtos de performance os tornam tão resistentes e seguros contra rupturas que os alpinistas confiam-lhes até (mesmo) sua vida."

"Was gute Bergseile ausmacht, sehen höchstens Experten."

Fraseologismo modalizador - 'Was gut- ... ausmacht $\backslash O$ que importa (é decisivo, obrigatório) para (...) é...' - É um marcador de modalização, usado no processo de construção de sentido que indica o valor positivo daquilo que se diz. Além disso, essa expressão, realçada pela inversão, provoca um reforço na modalização.

Operador de restrição - höchstens Experten sehen, was.../ no máximo os especialistas vêem ... - Os leigos, com certeza a grande maioria da população, que nem pratica esse esporte, nem entende de cordas de alpinismo, não têm nada a dizer. O operador 'no máximo' trabalha com a exclusão e deixa apenas os especialistas opinarem. Colocando o enunciado de outra maneira, ficaria: "no 
máximo os especialistas conhecem o fundamental para um bom alpinismo". Indica para: 'fundamental é o uso de materiais da BASF'.

Índice lexical de avaliação - Experten - o uso do termo 'especialista' funciona como uma modalização positiva, já que, atualmente, em nossa sociedade, ele adquiriu um caráter quase onipotente. Levando-se em consideração a insegurança dos indivíduos, provocada por mudanças aceleradas na sociedade de hoje, é ele, o especialista, que vai determinar sobre tudo. Quando se coloca a palavra 'especialistas' sai de cena qualquer objeção que possa ser feita por não-especialistas, pessoas 'normais', que não são capazes de 'ver' o que é fundamental para não se despencar da montanha (da vida?).

Índice de polifonia - O posto é: “..., sehen höchstens Experten”. Existe o 'pressuposto' de que 'os especialistas' já estudaram e determinaram o que é essencial para a segurança do indivíduo. E o subentendido é: quem não quiser correr perigo numa hora dessas, é melhor fazer uso de produtos da BASF. A conseqüência é a conclusão de que só nos cabe aceitar o que está sendo afirmado como verdade inquestionável.

O enunciador mantém-se coerente ao optar pela construção dos ethé de competência e confiabilidade, já observados anteriormente, pois é com esse inventário perceptual que a BASF busca ancorar-se afetivamente na mente dos consumidores dos anúncios.

'Denn wie so viele Produkte verdanken sie ihre Qualität einem versteckten Beitrag.' ' 'Pois, como tantos outros produtos, eles devem sua qualidade a uma contribuição oculta'.

Este enunciado equivale ao enunciado do primeiro anúncio: 'Aber sie leistet wie viele unserer Lösungen Elementares'.

Operador argumentativo - denn/pois - vem direcionar a conclusão, introduzindo um esclarecimento, através de uma especificação, do enunciado anterior, no caso, o que torna o alpinismo seguro.

Operador comparativo - wie so vielel como tantos outros - reforçando a idéia já apresentada no outro anúncio, indica uma relação de igualdade entre os 
'outros tantos' produtos que devem agradecer à contribuição da BASF. Continua a tendência a igualar todos no anonimato, enquanto realça a quantidade de produtos com os quais a BASF contribui.

Índice lexical de avaliação - 'Qualität' - Não esquecendo que esta é uma das palavras de plástico mencionadas por Pörksen (1988), que aqui é bem adequada ao uso que ele analisa para elas: 'amplo espectro e por isso vaga'. Proporciona essa aparência de cientificidade, objetividade e que aciona formações discursivas sem necessidade de vincular-se a um determinado ponto de vista.

Uso de sinonímia - 'einem versteckten Beitrag \uma oculta contribuição' - a retomada das mesmas idéias auxilia a coerência do texto. Essa expressão retoma e reforça a idéia do título - 'invisível contribuição'. Trabalha-se para que seja criada uma cumplicidade entre o leitor e a BASF. Por esse motivo, é introduzido o pressuposto de que existe essa contribuição escondida, já que 'tantos outros' produtos agradecem por isso. Além do que, com a nominalização do verbo 'beitragen' e o uso de 'verstecken' no particípio como atributo de 'Beitrag', não se tem idéia de quem escondeu o quê, onde, de quem, com que propósito. O jogo entre visível e invisível é cultivado.

"Unsere Performancematerialien machen sie so strapazierfähig und reissfest, dass Kletterer ihnen sogar ihr Leben anvertrauen. I Nossos produtos de performance os tornam tão resistentes e seguros contra rupturas, que os alpinistas confiam-Ihes até (mesmo) sua vida."

Inscrição do sujeito no enunciado - unsere - item discutido no anúncio anterior. Continua o uso claro do 'nós' comodificado, ilusório e alienante, proposto por Fowler; Kress (1979) e Fairclough (200). O referente sobre o qual a BASF constrói seu discurso inicial continuam sendo suas contribuições.

Índice lexical de avaliação - Performancematerialien\'material de performance', como traduzido pela própria BASF no anúncio brasileiro. Algo que apresenta rendimento mais eficiente \Leistung (termo já discutido). É 'o amuleto', 'a pitada esotérica' que faz com que o personagem pendurado pela corda não caia 
no abismo. É na confiança desse termo técnico que nosso herói deposita sua vida -'dass Kletterer innen sogar ihr Leben anvertrauen'. Esse teermo reforça os ethé de fidedignidade, competência e poder por parte da BASF, e de ousadia, coragem e inteligência do leitor, que se torna como que um cúmplice na construção desses sentidos induzidos pela BASF

Operador argumentativo - so (...), dass/tão (...) que - uma relação consecutiva de causa e conseqüência, na qual o antecedente, a causa, implica o conseqüente. O mais importante dessa relação é que o que se afirma existir no antecedente é essencial para validar o conseqüente.

No caso acima, a conseqüência é baseada numa proposição com um índice de polifonia, pois é dado como pressuposto que os alpinistas confiam suas vidas à BASF, e que isso é, além de verdade, um conhecimento partilhado por todos, que: "Kletterer vertrauen BASF ihr Leben an./Os alpinistas confiam sua vida à BASF."

É difícil questionar o enunciado da forma como ele é encadeado, pois o pressuposto é taxativo, dado como conseqüência do enunciado anterior. $O$ pressuposto torna-se conseqüência, que é partilhada por todos. O posto é a performance dos materiais.

Operador argumentativo de inclusão e índice de polifonia - sogar \até escolhe e introduz o argumento mais forte de uma escala $(\mathrm{KOCH}, 1996)$ que, nesse caso, é, nada menos, que a vida dos alpinistas. Dessa forma, orienta no sentido da conclusão desejada: a importância 'vital' da BASF. Provoca, também, um índice de polifonia, pois dá a entender que estes confiam à BASF outras coisas além da própria vida, que é o mais importante. Funciona como um 'plus' para terminar de persuadir sobre a importância da empresa.

Modalidade - a escolha dos termos já determina a modalização do argumento: 'strapazierfähig und reissfest/ resistentes e seguros contra rupturas', está de acordo com a orientação da argumentação iniciada com a foto que compõe o anúncio. Levando em consideração a situação dramática em que se encontra o homem da fotografia, arriscando sua vida, seguro apenas por uma corda, com materiais de performance da qualidade BASF, nada mais de acordo 
com a necessidade de resistência e segurança. Ocorre a redundância entre a foto e o texto lingüístico, ambos se reforçando.

\section{Conclusão parcial}

Continua a proposta de indução aos mesmos ethé anteriores, agora, talvez até de modo mais acentuado, visto que o esporte apresenta risco ainda maior.

A estratégia de argumentação da BASF segue na mesma linha que o anúncio anterior. O 'attentum parare e captatio benevolenciae' ou Atenção e Interesse do esquema AIDA, provavelmente, é bem sucedido com o uso desse tipo de foto impactante e adrenérgica. Na dispositio, os elementos são mantidos, tanto na retórica lingüística como na retórica da imagem.

O exordium continua o mesmo, apenas variando de posicionamento. É usado em lugares decisivos, tanto para chamar a atenção como para completar o objetivo com que a imagem é usada, que é realçar a importância da BASF em momentos decisivos na vida das pessoas, embora nem todos se dêem conta disso.

A narratio ocorre por intermédio da foto, que preenche a função de enumerar detalhes, bem como de fornecer os argumentos sobre o assunto, pois a dramaticidade da imagem é uma boa argumentação visual sobre como é seguro optar pela BASF em tais momentos. Esta também ocorre pelo material lingüístico, já por meio da introdução do 'diferencial' para a prática do 'Bergseil' em segurança. Em seguida vem o fornecimento dos motivos, para isso faz-se o uso do 'denn', 'so (...), dass .... A peroratio é a mesma do anúncio anterior.

O mesmo inventário perceptual do anúncio anterior é acionado neste. A BASF se liga afetivamente aos leitores, vinculando-se a pessoas inteligentes, em atividades que exigem rendimento de alto risco, independência, coragem, e não às ingênuas a ponto de se aventurar sem cuidar de sua absoluta segurança, tanto que escolhem a BASF.

Os heróis da BASF continuam realizando empreendimentos que colocam sua vida em risco, mas eles sabem pesar, equilibrar desafios, ousam com segurança, de forma a possibilitar o sucesso. Nesse papel, o mentor e o herói se 
unem. O primeiro, para possibilitar o sucesso. O segundo, a usufruir o sucesso que conquistou, auxiliado pelo mentor.

São reafirmados os mesmos ethé de competência, seriedade e solidariedade, imaginando-se que ninguém iria confiar a própria vida a indivíduos ou instituições incompetentes e não fidedignas. Continua a BASF apresentando-se no papel de 'mentor' que fornece o elemento mitológico mágico para que o indivíduo vença os desafios, isto é, a tecnologia avançada, a chave da competência.

O inventário perceptual que compõe a imagem do consumidor continua sendo o de um consumidor ativo, ousado, participante e efetivo na busca de seu sucesso, mesmo correndo risco de vida. Essa imagem é criada através da conjunção da montagem da fotografia com a identidade discursiva construída pela BASF, onde aciona os mesmos ethé do anúncio analisado anteriormente

Pode-se afirmar que, neste anúncio, os mesmos arquétipos do anúncio anterior, o Grande Pai e o herói, fazem parte do inventário perceptual, com o qual a BASF procura se ligar, afetivamente, ao espaço mental dos consumidores alemães.

O enunciado - "Unsere Performancematerialien machen sie so strapazierfähig und reissfest, dass Kletterer ihnen sogar ihr Leben anvertrauen." pode ser considerado um equivalente do enunciado do primeiro anúncio - "Aber sie leistet wie viele unserer Lösungen Elementares: Sie trotzt auch unter Extrembedingungen Wind und Wetter. Und schützt damit Menschen vor Kälte und Nässe."

Percebe-se que, nesses dois anúncios, ocorre a repetição de tema, tanto nas fotos como nos textos. O que muda, um pouco, são as figuras, isto é, a forma como o tema vem à tona no discurso e na imagem. O tema sobre o qual se fala é o mesmo: situação em que os personagens têm que realizar tarefas árduas e desafiantes. Encontram-se em perigo e necessitam de auxílio de outros, mesmo que indiretamente. A organização da argumentação lingüística e visual, os conteúdos semânticos, materializam a idéia de audácia, ousadia por parte dos usuários de produtos da BASF e de competência, fidedignidade, solidariedade, 
poder e liderança, por parte da instituição. Muitas outras possíveis imagens mentais podem ser acionadas a partir desses dois anúncios, tanto que essas fotos poderiam ser substituídas por qualquer outra imagem de esporte radical que represente perigo. Ou mesmo por outra imagem, na qual possa haver necessidade de equipamentos especiais, sejam eles a "Textilbeschichtigung", do primeiro anúncio ou qualquer outro item no qual a BASF participe com sua tecnologia, sem que haja perda de sentidos.

Esses anúncios - assim como a publicidade em geral, por ter um caráter ecoante - são capazes de ancorar-se, com facilidade, no espaço mental do consumidor, por intermédio, justamente, das imagens visuais e lingüísticas repetitivas que veiculam. A repetitividade da argumentação lingüística e imagética proporciona similaridade e ordenamento no que possa haver de heterogêneo nas imagens.

O esquema cognitivo deve apoiar-se no script que evoca um indivíduo numa situação de risco, ou seja, um indivíduo que busca esportes que provocam a liberação de altos índices de adrenalina (hormônio neurotransmissor presente no sistema nervoso em situações de estresse).

Esse script é ao mesmo tempo individual e social, isto é, faz parte da cognição social (VAN DIJK, 1997), que são estratégias e estruturas mentais partilhadas por indivíduos da mesma comunidade, e que induzem a representações semelhantes. Refere-se ao que deve ser a prática 'segura' de um 'esporte de alto risco'. Traz, implicitamente, valores que induzem a uma forma de viver que, de algum modo, exige esse tipo de rendimento.

É uma construção ideológica, no momento em que prescreve e veicula o mito de um estilo de vida (de atividades) que teoricamente é possível ou desejável para todos, com algumas diferenças, já que alguns indivíduos preferem alpinismo, outros, escaladas etc. É ideológico por refletir um estilo de vida em que os desafios do esporte se confundem com o campo do trabalho na cognição social alemã (HOLLY, 2006). Como se a vida cotidiana fosse uma sucessão de desafios semelhantes a esses, nos quais a BASF estaria presente para incentivar e 
proteger, ao mesmo tempo em que prega o mito de competência, ousadia e segurança proporcionadas pelo 'seu' avanço científico. 


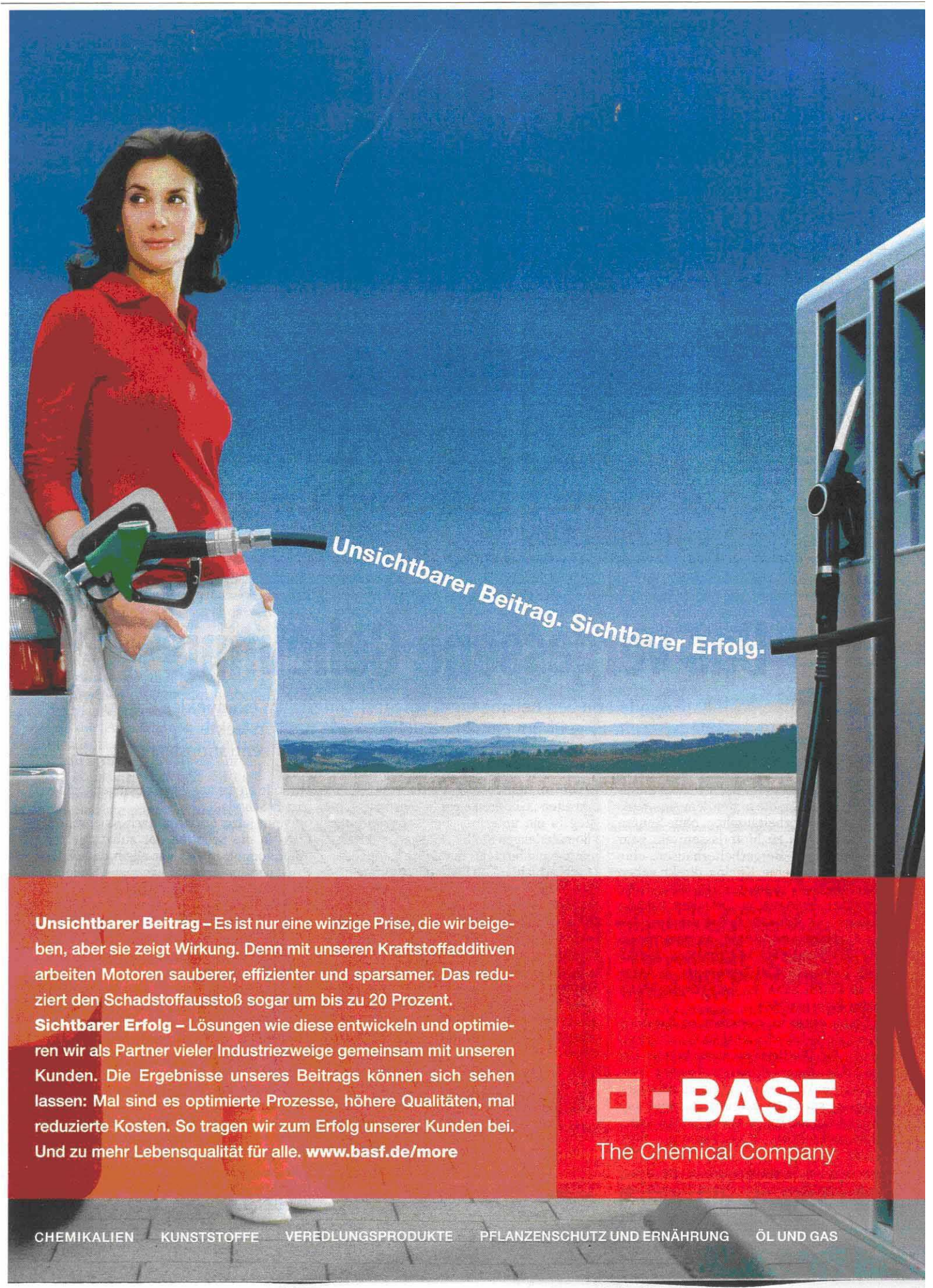




\subsection{Anúncio publicado nos números da revista 'der Spiegel' de 17/09/05}

Análise da composição visual do anúncio - Uma mulher, aparentando entre 20 e 30 anos, encontra-se encostada em um carro, à sua esquerda, de lado para o leitor do anúncio, com a parte da frente em direção à bomba de gasolina. A mangueira, em primeiro plano, sai da bomba e segue em direção ao bocal do tanque do carro, penetrando-o, passando pela frente da mulher, bem à altura de sua cintura. A parte central da foto da mangueira é apagada e seu trajeto é percorrido pelo título do anúncio: "Unsichtbarer Beitrag. Sichtbarer Erfolg". No anúncio anteriormente analisado, o azul era a cor preponderante. Este anúncio divide-se entre o azul, o vermelho e o branco.

A cor é o elemento que mais, espontaneamente, mexe com a emoção no processo da percepção visual. Ela tem o poder de intensificar a informação visual (KRESS; VAN LEEUWEN, 2001) e já que a comunicação ocorre dentro de estruturas sociais pré-determinadas, estas se encontram marcadas por diferenças de poder. O vermelho se sobrepõe ao azul, assim como o que está na frente se sobrepõe ao que está atrás, o que está no lado esquerdo tende a ser mais marcante do que o que está no lado direito, pelo menos no modo ocidental de organizar o mundo.

A cor vermelha foi usada conjuntamente com a composição dos elementos na foto, tanto que aparece na frente e no lado esquerdo. O que se sobressai é o vermelho e o que está dentro dele. Destaca-se, portanto, o logotipo da BASF, o texto lingüístico e a mulher. Como a leitura da imagem ocorre, normalmente, em forma de um "Z" (JOLY, 2005), podemos sugerir o percurso: a mulher de blusa vermelha, a mangueira com os dizeres e o texto, passando pela parte inferior do corpo da mulher que, sugestivamente vem em branco (indicando pureza?), e terminando no logotipo da BASF.

A opção pela cor vermelha, considerada uma cor quente, procura implicar emoções fortes, sensualidade, erotismo, enquanto o uso da cor branca, na calça, no sapato, no carro e na mureta, dá o contraponto para a inocência. Nessa sintaxe visual, mantêm-se discursos subjacentes ambíguos. 
A mangueira da bomba de gasolina transpassa a mulher, bem à altura de sua pélvis, quase nos genitais, e penetra na boca do tanque do carro. A foto nos chega como se a mangueira entrasse primeiramente nela e depois no carro.

Key (1990), em seu livro 'A Era da Manipulação', apresenta vários anúncios nos quais imagens são inseridas de maeira subliminar e, sem dúvida, intencionalmente. $O$ autor discute que, apesar de essas formas não serem percebidas conscientemente, tais imagens são registradas pelo subconsciente, e, quanto mais tenham a ver com a sexualidade mais fortemente são registradas sem o conhecimento dos indivíduos. Influenciam, dessa forma, profundamente nas opções de consumo da população.

Segundo o mesmo autor, apesar de várias tentativas dos órgãos de regulação publicitária de coibir tal prática, o uso de propaganda subliminar continua a ser feito por agências dos mais variados países. O que pode também ser comprovado nessa pesquisa.

A face da modelo do anúncio também é construída de maneira interessante. É um rosto no qual podemos identificar um certo tom de prazer, malícia. Parece um sorriso de 'Mona Lisa', enigmático, com um certo tom de malícia. É completamente destoante de alguém que está pondo gasolina no carro. Ao mesmo tempo aparenta ser um rosto que mostra uma pessoa decidida. Ela não encara o leitor, mas algo que está à esquerda dele.

Como nos anúncios anteriores, nesse também existem vetores que têm a função de orientar o olhar dos leitores, caso esses não consigam encontrar 0 caminho rapidamente. O corpo da figura feminina funciona como o vetor que orienta para o texto. Se prestarmos atenção, veremos que o texto se encontra sobre uma superfície translúcida, o que permite ver a continuação das pernas da modelo até seus pés. Enquanto as pernas dirigem nosso olhar para o corpo do texto, os pés apontam para os produtos fabricados pela BASF. Nada se perde em peças publicitárias como esta, tudo tem função. As bombas de gasolina e duas de suas mangueiras orientam para o logotipo. A terceira mangueira vira o título do anúncio, enquanto se orienta para a região pélvica da mulher e o seu bico (símbolo fálico) se insere no bocal do tanque do carro. 
O anúncio apresenta uma divisão horizontal muito clara, feita pela mureta ao fundo e pela mangueira em primeiro plano. A mangueira, no caso, representa metonimicamente o elemento para o qual a BASF quer chamar a atenção: os produtos da BASF. Se levarmos em conta a análise da significação da mangueira, pode-se afirmar que representa a potência dos produtos da BASF, que não aparece dessa vez no mito do herói, mas no produto em si (gasolina), e nos elementos fálicos, estratégica (e sutilmente?) inseridos no anúncio.

Como o texto visual começa a ser lido pelo lado esquerdo, por isso a tendência de colocar, nesse lado, o elemento conhecido, a partir do qual a leitura se inicia. À esquerda vê-se a mulher, o carro e o gatilho da bomba. Não deixa de ser um chavão bem conhecido o de ligar figuras femininas a carros, colocando ambos como disponíveis. À direita, estão as bombas de gasolina, petroquímica com a qual a BASF contribui. Isso é a informação que se pretende nova, cuja ligação é feita pela mangueira.

A personagem se encosta obliquamente no carro, estaticamente, sem nem segurar a bomba. A linha oblíqua indica instabilidade, tensão. Dessa forma, buscase talvez a idéia de fragilidade, pois aparenta necessitar de um apoio que a sustente. É um apoio muito diverso do que necessita o personagem do segundo anúncio pendurado pelo cordão. Enquanto o participante na neve olha para a direita e para o alto, indicando um olhar de quem determina o seu futuro, um olhar de quem atua, ela olha para a esquerda, para trás, indicando, talvez, passado.

De acordo com Kress; van Leeuwen (2001), os personagens masculinos tendem a olhar fixamente para o horizonte, exatamente como o olhar do personagem do primeiro anúncio. O olhar da personagem do anúncio, ora analisado, é um olhar tradicionalmente imposto a personagens femininas. Estas, freqüentemente, parecem olhar perdidamente para coisas relativamente próximas a elas, aparentando estarem absortas com o entorno imediato. Não olham diretamente para o interlocutor.

Em ambos os tipos de olhares, cabe aos leitores uma cumplicidade para imaginar o que ambos olham, o que provoca uma sensação de empatia com os participantes representados. No caso do primeiro anúncio, os leitores identificam, 
no olhar do personagem, um próximo desafio a ser conquistado, no segundo, apenas intuem a existência de algo próximo, comum.

Embora o corpo da mulher funcione como um vetor que indica o texto, existem linhas que definem para ela um lugar na composição do anúncio. Ela se encontra como que imobilizada entre o carro, a bomba de gasolina, a mureta que existe entre ela e o horizonte e a mangueira à sua frente, que a separa do leitor. Teoricamente, ela não pode sair daí até a mangueira ser retirada do bocal. Seu espaço fica demarcado por essa estrutura de linhas. Essas linhas funcionam como uma moldura a estabelecer o limite dentro do qual o leitor deve permanecer ao ler essas imagens. Não é uma imagem aberta como as do primeiro e do segundo anúncios. Ela é limitada pelos quatro lados. Esses elementos fazem com que criemos uma 'leitura centrípeta'. O único elemento a sair do anúncio é o olhar da personagem. Resta a nós, leitores, sermos 'cúmplices' desse olhar.

Análise da composição lingüística - $O$ anúncio segue exatamente o mesmo esquema dos outros. O único elemento textual lingüístico que diferencia este anúncio dos anteriores é a primeira parte do corpo do texto.

\section{Primeira parte}

"Unsichtbarer Beitrag - es ist nur eine winzige Prise, die wir beigeben, aber sie zeigt Wirkung. Denn mit unseren Kraftstoffadditiven arbeiten Motoren sauberer, effizienter und sparsamer. Das reduziert den Schadstoffausstoss sogar um bis 20 Prozent."

“Contribuição invisível - é apenas uma ínfima pitada que nós agregamos, mas ela demonstra efeito, pois, com nossos aditivos de combustível, os motores trabalham de maneira mais limpa, mais eficiente e mais econômica. Isso reduz a emissão de poluentes em até 20 por cento."

'es ist nur eine winzige Prise, die wir beigeben, aber sie zeigt Wirkung.' 
Fraseologismo - eine winzige Prise ... beigeben - expressão comum em receitas culinárias, tanto que, de quatro dicionários pesquisados, três forneciam, como exemplo de uso, expressões ligadas a esse campo:

Man sollte dem Teig eine Prise Salz beigeben (BALHAR, 2004)

Dem Gulasch noch Paprika beigeben (WAHRIG, 1977)

Dem Teig ein Ei beigeben (GÖTZ, 2002) .

Remete ao script de atividades culinárias, encaradas, normalmente, como fazendo parte do mundo feminino, na área de atuação doméstica. Isso indica uma certa intimidade, como se a BASF passasse para seus leitores a receita de um produto criado por ela e solidariamente compartilhada com os usuários.

Aliteração - por intermédio da vogal 'i' e também das consoantes 's' e ' $z$ ': 'ist, winzige, Prise, die, wir, sie zeigt Wirkung.'

Operador - nur - de restrição. Refere-se à 'minúscula pitada'. São três elementos lingüísticos, reforçando o quanto é pequena contribuição da BASF. É ínfima. Se a argumentação continuar nessa direção o leitor deste anúncio, da mesma forma que nos anúncios anteriores, vai achar que a BASF não serve para nada, já que sua contribuição é tão desprezível.

Operador - aber/mas - depois de realçar, através do léxico, o quão pequena é a 'contribuição/Beitrag', usa-se um operador que inverta o sentido da conclusão na direção da importância, isto é, oriente para a essencialidade do que é minúsculo/winzig. É justamente o uso desse exagero em direção ao 'pequeno' na primeira proposição que vai realçar a proposição introduzida pelo operador 'aber', ou seja, o 'efeito/Wirkung' é fundamental. Retoma o termo Leistung/rendimento do outros anúncios. Dessa forma o que é feito pela BASF assume maior importância do que se fosse defendido desde o início. Isso proporciona um índice de polifonia que serve para desmontar um possível discurso que exista sobre o quão pequena é a contribuição dessa indústria, além de funcionar como um índice de honestidade por parte da BASF, que reconhece que ela não é responsável por tudo, mas, apenas pelo que 'é importante'. A mesma estratégia argumentativa dos anúncios anteriores. 
'Denn mit unseren Kraftstoffadditiven arbeiten Motoren sauberer, effizienter und sparsamer.'

Operador - Denn/ pois - exige que uma argumentação já venha sendo feita, para poder então levar a uma conclusão em relação ao que foi dito anteriormente. Polenz (1985, p. 272) coloca esse operador no grupo das conjunções que 'especificam', tornam o argumento que veio antes 'mais claro'. Vogt (1989) analisa esse operador em língua portuguesa, mas sua análise também pode ser aplicada à língua alemã:

... mesmo que se encontre num texto a conjunção 'pois' depois de um ponto final, ou ainda no início de um novo parágrafo. A condição é que exista sempre um enunciado no texto antes do enunciado a ele ligado pela conjunção pois, isto é, ... (VOGT, 1989, p. 47)

A argumentação anterior ao qual o 'pois' se liga para dirigir à conclusão desejada é: 'é pouco, mas é determinante' e conduz ao efeito que faz a diferença.

Modalização - o uso da expressão 'mit unseren/com os nossos' já modaliza a frase. Ao fazer a inversão, essa modalização é potencializada, deixando mais claro e reforçando o papel dos produtos da BASF nesse contexto de eficiência. Reforça, juntamente com 'denn', o ethos de competência que já havia sido iniciado por 'zeigt Wirkung/ mostra resultado.'

Índice de avaliação Lexical - organizados em forma de operador classe argumentativa, os termos funcionam como argumento de autoridade. A conclusão à qual o leitor é orientado é: os potentes aditivos/Kraftstoffadditiven dos motores transformam tudo em superlativo: sauberer/mais limpo, effizienter/mais eficiente, sparsamer/mais econômico.

- Sauberer/mais limpo = a mitologia da pureza transparece, além do texto, na imagem da mulher branca/alva, limpa, com calças brancas imaculadas. Constrói um ethos de virtude e, ao mesmo tempo, de intimidade e malícia, também induzida pela cor vermelha de sua blusa. A existência de um ethos não impede outros, já que eles são cruzamentos de vários olhares e complementares. 
- Effizienter/mais eficiente = está de acordo com a mitologia da eficiência que a BASF cultua claramente em seus anúncios: 'Leistung'. E que dentro da cultura germânica encontra visível ressonância. O olhar da personagem, seguro de si, é de quem sabe lidar sozinho com situações. Percebe-se que não existe ninguém, pelo menos na parte visível representada. Constrói-se aí, mais uma vez, o ethos de competência e, também, de independência.

- sparsamer/mais econômico = que economiza tempo, dinheiro, é moderno ecologicamente, poupa o meio ambiente. E é um dos grandes motos do capitalismo: 'custo x benefício'. Ao mesmo tempo em que constrói um ethos de solidariedade, já que se demonstra preocupado com o gasto do usuário, com a poluição, com o meio ambiente, ao qual a figura feminina é mais tradicionalmente vinculada.

Essas três qualidades serão retomadas e reforçadas na segunda parte do texto, que é o mesmo para todos os anúncios, com os termos:

- optimierte Prozesse = effizienter;

- $\quad$ reduzierte Kosten = sparsamer;

- höhere Qualität = sauberer; pode-se considerar que mais qualidade pode implicar também mais limpeza/pureza.

'Das reduziert den Schadstoffausstoss sogar um bis 20 Prozent.'

Operador - sogar/até - que orienta para o argumento mais forte no sentido de uma determinada conclusão. Os argumentos anteriores funcionam como uma classe argumentativa que é arrematada pelo operador 'sogar' com um argumento muito forte, no sentido de que se esperava menos do que, na realidade, se recebe, no caso imbatível, uma quantificação matemática. A matemática em geral parece ter o poder de transformar o mundo em medidas inquestionáveis. Porém, de acordo com o do tipo de operadores escolhidos, o quantificador pode representar muito ou pouco, dependendo do ponto de comparação escolhido (BARQUETA: 1999). No anúncio aparece como sendo o argumento mais forte escolhido para dar o xeque-mate na condução da conclusão. Também um argumento de autoridade. 
Se fosse no discurso de um ecologista, essa medida matemática tão exata poderia aparecer como um quantificador que expusesse a deficiência dos motores: 'Diminuem em 'apenas' 20 por cento a quantidade de poluentes lançados no meio ambiente.' Dependendo do operador argumentativo, do encadeamento argumentativo escolhido, as medidas exatas assumem diferentes valorizações.

Operador de conjunção - 'und' - de argumentos que levam à mesma conclusão, no caso os dois argumentos de autoridade.

\section{Inventário Perceptual Mitológico -}

Os elementos lingüísticos como 'sauber/limpo, o branco da calça, do sapato, do carro e da mureta, a alvura da mulher e também a sua idade, evocam esse script de pureza, de mundo que está em paz e seguro entre a moldura. Contribui para isso a expressão fraseológica 'winzige Prise beigeben', que indica um mundo doméstico, que faz parte dessa pureza e segurança. Institui-se, dessa forma, uma identidade discursiva que a BASF constrói para si, baseada no ethos de virtude.

'Effizienter' institui um ethos de seriedade de quem trabalha/leisten, assim como 'sparsam', que indica um ethos de solidariedade, de alguém que está preocupado com 'o bolso' do outro. As mencionadas qualidades dos 'Krafstoffadditiven' demonstram um ethos de competência. Ao mesmo tempo, os tons em vermelho, já discutidos, infiltram a idéia de que existe uma sexualidade, por parte da personagem, disponível ao leitor. Esses componentes, no anúncio, são interligados de modo mais ambíguo.

Não apela para o mito do herói, como nas duas anteriores. Poderia ter seguido o mesmo tema e colocado uma mulher esquiando, ou qualquer outro esporte que demonstrasse a audácia de uma heroína. E ao mesmo tempo, fizesse a ponte associativa com o mundo do trabalho exaustivo, obstinado. Ao invés disso, temos uma mulher dentro de um espaço de ação limitado fisicamente, como foi analisado. Ela aparenta estar isolada do mundo, dentro de quatro paredes, dentro de seu mundo feminino, tecendo suas receitas culinárias (winzige Prize beigeben), à espera. 
O arquétipo, no qual esse anúncio busca apoiar-se, é o da deusa Perséfone. Esse arquétipo, assim como muitos outros, tem a função de esclarecer alguns comportamentos femininos em relação aos mundos nos quais a mulher interage. Perséfone é a filha de Deméter com Zeus, após esta ter sido subjugada e violentada (BRANDÃO,1993, p. 345). Perséfone, Deméter e Hera formam a tríade das deusas “... dominadas à força ou humilhadas por seus pares divinos." As três foram violentadas.

A primeira delas, que é a de nosso interesse, nessa análise, é representada como uma virgem, que ao passear nos bosques é seqüestrada por Hades e mantida prisioneira no inferno por seu seqüestrador. Quando um emissário de Zeus tenta resgatá-la, a pedido de sua mãe, Hades lhe dá de presente algumas sementes que ela, inadvertidamente, come e dessa forma fica eternamente à disposição do inferno.

A forma como Hades a seqüestra, e como a fecunda, simbolicamente, por intermédio do estratagema de fazê-la ingerir as sementes, antes que saísse do inferno, demonstra que ela não só está à disposição para ser colhida, como também não é completamente responsável por seus atos e que, portanto, tem, sempre, a necessidade de ter alguém mais capaz a guiá-la para que não seja prejudicada por suas atitudes irresponsáveis.

Ela faz par complementar com sua mãe Deméter, a eterna mãe. Isso indica que a primeira mantém, entre outras, as características de ser eternamente jovem, filha e ao mesmo tempo inconseqüente. Outra característica de Perséfone é que, sendo esposa de Hades, é a rainha do inferno. O inferno simboliza o mundo das forças tectônicas, não controláveis. Por isso essa ambigüidade da inocência e pureza, ao mesmo tempo em que a disponibilidade é insinuada pelas cores e símbolos fálicos que aparecem no anúncio, representando as forças instintivas, não controláveis, a sexualidade.

Esse arquétipo procura explicar um tipo de relação homem/mulher que conduz ao comportamento amoroso/sexual. Sem o arquétipo de Perséfone, o encontro amoroso não ocorre. Este arquétipo é necessário. O problema surge 
quando o comportamento feminino é restrito à expressão de Perséfone, cercada no espaço que lhe é destinado.

Este mito “... predispõe a mulher a não agir, mas a ser conduzida pelos outros, a ser complacente na ação e passiva na atitude. Perséfone, a jovem, também permite à mulher parecer eternamente jovem" (BOLEM, 2005, p. 277).

Algumas de suas traduções em mitos ocorrem como mulheres fatais, como eternas filhas ou como as duas coisas. Mais ou menos como a imagem que se criou e cultivou-se da atriz Marilyn Monroe. Uma mulher que tem características ambíguas como as de uma criança ingênua e ao mesmo tempo de uma sedutora fatal, sem nem mesmo se dar conta disso e nem do 'mal' que provoca. Uma outra excelente expressão desse arquétipo pode ser encontrada na heroína do filme 'Caixa de Pandora', de Murnau.

De acordo com a análise, o que vemos é essa mulher absorta em sua contemplação e, passivamente, cercada em seu espaço, com seu sorriso enigmático, que se mantém congelada, indecifrável e disponível.

A figura do Grande Pai não entra aí como estímulo a grandes feitos, mas, patriarcalmente, compõe com a Grande Mãe, uma tentativa de proteção da virgem, mantendo-a entre quatro paredes, mas sem conseguir ao todo o seu intento, já que os estímulos/perigos exteriores são muitos, como pode ser visto subliminarmente no anúncio.

Como arquétipo que é, Perséfone deve ter seu mito atualizado, portanto, essa mulher não pode aparecer como infantilizada e dependente. Isso criaria uma rejeição automática ao anúncio, já que, aparentemente, todos concordam que esse não é mais o lugar que cabe à mulher dentro da sociedade. Perséfone se atualiza, nesse anúncio, ao saber dirigir, colocar gasolina no seu carro sozinha, que são coisas básicas para uma mulher na Alemanha. Mas continua protegida pela tecnologia fornecida pela BASF que possibilita que ela se mantenha limpa, 'as máquinas' sejam mais puras, eficientes e econômicas.

Como em todos os anúncios da BASF alemã, essa personagem nos é apresentada de maneira solitária, aparentando autonomia. Porém, se, aparentemente, parece ser dona de seu destino, subliminarmente percebemos 
que sua situação não é determinada por si própria, como ocorre com os personagens masculinos nos anúncios anteriores. Mas por uma solidão imposta pelo isolamento das linhas que constroem o anúncio.

\section{Conclusão parcial}

Pode-se perceber que a linha de argumentação escolhida é a mesma dos anúncios analisados anteriormente.

- Unsichtbar (negativo), nur (negativo) winzige (reforço do negativo); Prise (reforço), aber (inversão da orientação para conclusão - eficaz), denn ( introdução do motivo); arbeiten (motivo $=+$ comparativo sem o termo com o qual se compara), sogar (até - motivo adicional).

No primeiro anúncio temos:

- Unsichtbar (negativo) - blossem Auge (nur - negativo no sentido de exclusão), kaum (negativo - excluindo), aber (inversão do argumento mudando conclusão), leistet Elementares (motivo, justificativa para mudança da conclusão), denn (substituído por dois pontos), trotzt (motivo), schützen (motivo adicional, um plus).

É repetido o esquema: negação de uma maioria, para realce posterior da minoria, que detém a competência, que se traduz como sendo a BASF. A inversão da orientação na argumentação é introduzida pelo operador argumentativo 'mas'. Depois o uso do operador argumentativo 'denn' para a introdução dos motivos que justificam a inversão, levando à conclusão da essencialidade da BASF. É visível o que importa: o sucesso, as soluções, a performance, denn/pois as causas para isso tudo só a BASF detém.

Nos anúncios anteriores, louva-se a audácia, coragem etc. elementos do script de heróis com grandes feitos, o campo lexical chamado para demonstrar isso remete a elementos da natureza que exigem sobrevivência em situação extrema e, portanto apelam à performance nessas situações.

No terceiro anúncio, o fraseologismo - 'eine winzige Prise beigeben' Oinclui a expressão 'adicionar uma pitada', que sem dúvida, lembra uma receita 
culinária, aciona script de um mundo doméstico, feminino, o que é reforçado pela foto.

Se fosse uma fórmula química, não teria esse componente de incerteza como 'uma pitada'. Parece remeter a mulher ao seu verdadeiro lugar, que é na esfera do mundo doméstico com suas peculiaridades do cotidiano. A BASF continua conjugando, no inventário perceptual do leitor, performance tecnológica com características afetivas, por intermédio dos fraseologismos que evocam scripts familiares aos leitores.

Um outro fator que chama a atenção, é o uso da vogal 'i' para compor a aliteração do primeiro enunciado desse anúncio. Poder-se-ia pensar que o motivo para essa escolha é o fato da mulher ter um tom de voz mais agudo do que 0 homem. Esse recurso pode ter sido usado para reforçar no leitor, o que já aparece no fraseologismo escolhido e na composição da imagem, isto é, a evocação do 'mundo feminino' doméstico, com bolos e conversas em vozes agudas.

A seleção lexical também é repetitiva. Ela tem três eixos nas primeiras partes que insistem em:

> versteckt/ oculta, nur für Experten/só para especialistas, kaum erkennbar/ quase não reconhecível, winzig/minúscula, Prise/pitada,;;

> sucesso graças a Lösungen/soluções, Wirkung/efeito, Elementares, Leistung/rendimento, performance, eficiência, eficácia, qualidade, processos otimizados;

> proteção - seja para grandes feitos ou para o mundo doméstico, para a potência do herói ou para a segurança da heroína.

Não se fala em grandes feitos, tampouco cita a agressão das indústrias à natureza. Fala-se em mais limpeza, mais economia, mais eficiência. Demonstração de um estereótipo no qual a mulher é tida como sendo a mais ligada a fazer economias, a cuidar de seu entorno da melhor maneira possível. É construída, no anúncio, como um indivíduo que não gosta de dar grandes passos e nem grandes desafios, permanece mais ligada ao cotidiano das pequenas coisas. 
Apesar de este ser um estereótipo até certo ponto ultrapassado, já que a mulher de hoje caminha em direção à adoção de outros valores, o anúncio investe no que imagina ser aquela imagem da mulher mais doméstica e contida de algumas décadas atrás. Por isso aparece em um cercadinho que determina qual o seu espaço seguro de atuação. Ao mesmo tempo, coloca-a no papel de um objeto sexual à disposição do leitor, como foi comprovado por intermédio dos vetores e da mangueira de gasolina com o bocal final com símbolo fálico. O que indica o uso de elementos que acionam scripts bem tradicionais, tanto para o papel masculino quanto para o feminino.

Percebe-se que, enquanto os outros anúncios faziam uso acentuado da figura do herói e do Grande Pai para estimulá-los, quando se trata da figura feminina, retrocede-se para o tradicional papel estereotipado feminino. Não há, para ela, espaço para conquistas, como as masculinas, nos anúncios anteriores. A imagem da mulher, no anúncio analisado, sugere, também, independência e liberdade, só que dentro do que é visto, no anúncio, como universo feminino, um mundo limitado.

Pode-se afirmar que um dos arquétipos que, mais fortemente, rege esse anúncio seria o de Perséfone. $O$ arquétipo da mulher eternamente adolescente, incontrolável e disponível, que deve ser cuidada e dirigida porque traz consigo características de sexualidade com as quais o mundo patriarcal ainda não sabe lidar, por isso opta-se por cercá-la.

Os ethé acionados são idênticos nos três: competência, inteligência, poder, credibilidade. Nos dois primeiros, é construído, adicionalmente, o ethos de potência, pelo uso do herói com sua demonstração de ousadia, coragem e inteligência.

No terceiro anúncio, o contraponto a esse ethos de potência viril é realizado tanto pela criação de uma virtude ambígua (que aparece como pura, trajando parte de uma indumentária na cor branca, imaculada, e parte vermelha, cor ligada ao fogo, à sexualidade) como pelo ethos de potência como força da natureza que é inerente à mulher enquanto procriadora, à disposição do elemento masculino para ser fecundada, mantendo o espaço que Ihe foi definido há milênios. 
Outro vetor surge, nesse anúncio, para contribuir com esse ethos de potência ambíguo: a própria BASF com suas bombas e mangueiras fálicas. $\mathrm{O}$ ethos de potência, dessa vez, se refere à própria BASF e não sobre seus usuários. 


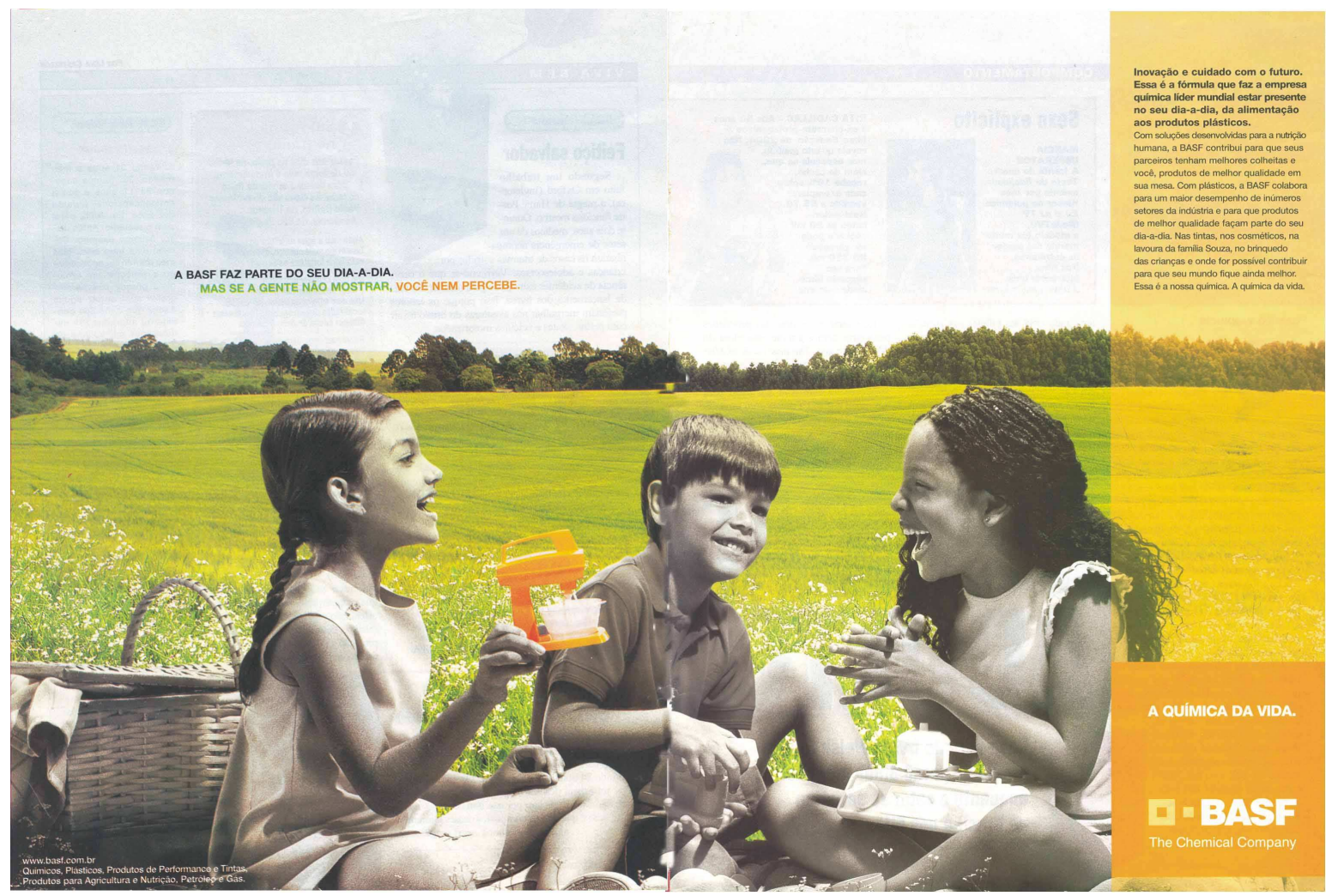




\subsection{Anúncio veiculado na revista Veja de 07-12-2005}

Análise da composição visual do anúncio - A foto, ao centro do anúncio, mostra três crianças sentadas, em primeiro plano, brincando em cima da grama, tendo um campo com fundo. Podemos ver, no lado esquerdo do anúncio, uma cesta de vime, que chama o script de piquenique, já que esta faz parte do imaginário, talvez não só brasileiro, de como deveria ser um piquenique. A toalha xadrez que sai um pouco da cesta confirma o script desejado pelo anúncio. As três crianças são mostradas seguindo a chamada política de ações afirmativas. São um menino e duas meninas, sendo uma delas negra. A BASF começa a construir para si, a partir da imagem, um ethos de solidariedade. Ela demonstra reconhecer que todos os usuários de seus produtos são iguais, sem diferença de gênero ou raça.

A imagem é dividida em retângulos. O primeiro é formado pelo céu e vai até a linha divisória delineada pela floresta que determina seu fim. O segundo retângulo é formado pelo campo cultivado, que se mostra em verde, mesclado com tons de amarelo. No lado direito, encontram-se mais dois retângulos verticais, como nos anúncios alemães de duas páginas. Um maior, na parte superior, onde é colocado o texto, que é em tom amarelo-alaranjado e um menor, abaixo, com a logomarca na cor laranja, fechando o anúncio. Dentro do retângulo verde amarelado - o campo -, estão as crianças em branco, preto e cinza. Elas estão brincando, sentadas em roda, ou melhor, em um semicírculo que se abre para 0 leitor, como que o convidando a ser a quarta pessoa nessa brincadeira. $O$ círculo leva a percepções psicológicas de proteção, segurança, aconchego (DONDIS, 2003).

Existem dois vetores principais e alguns secundários. O primeiro vetor é 0 braço da menina da esquerda, juntamente com o brinquedo em suas mãos, a cabeça e o corpo do menino indicam que o percurso do olhar do leitor deve seguir tanto para o texto de cima como para o texto abaixo da cesta.

O segundo vetor é formado pelo braço e cotovelo da menina da direita e indica o percurso do olhar para o logotipo, assim como para a cabeça do menino e 
em seguida para o exordium. A composição visual é feita na forma de um $X$ imaginário.

Os vetores secundários são formados pelo corpo da menina, na esquerda, que também indica para exordium, pelo braço do menino e pelo brinquedo no colo da menina negra. Estes, também, indicam para o logotipo, além da perna da menina da direita que está dobrada e tem na parte inferior e o joelho um vetor para o slogan expandido, enquanto a coxa forma um vetor para o logotipo.

Essa conjunção de linhas torna-se um jogo interessante, pois se olharmos melhor no círculo formado pelas crianças, podemos identificar que a cabeça do menino encontra-se no centro da página e é o vértice superior de um losango.

O lado esquerdo superior do losango é a linha formada pela cabeça do menino e vai até o cotovelo da menina branca, o lado direito superior é a linha que sai da mesma cabeça do menino e vai até o cotovelo da menina negra. Há outra linha que sai do joelho desta menina e desce pela perna até o pé que quase não vemos.

O vértice inferior desse losango é o leitor, que se encontra posicionado bem na frente do anúncio e dele sai uma linha que pode ser intuída como sendo a perna da menina branca que não se vê e se junta com seu cotovelo. Temos, aí, um losango, quase completo.

Existe ainda uma linha curva que é formada pelo braço da menina da esquerda, pelo braço do menino e pelo brinquedo, no colo da outra menina. Funciona como se fosse uma faixa que passa no centro do losango, formado pelos vetores e do círculo, formado pelas crianças e faz a ligação entre o texto da esquerda e o logotipo.

Embora as crianças estejam em branco e preto nessa imagem, podemos perceber que as cores definidoras do anúncio são o verde, amarelo e laranja. De qualquer forma, o laranja é uma cor que se aproxima do amarelo. Ele funciona como reforço, nesse jogo velado, para, possivelmente, levar o leitor a registrar inconscientemente os elementos da bandeira brasileira.

Enquanto a bandeira brasileira é um retângulo verde com um losango amarelo inserido e, dentro deste, um círculo azul com uma faixa branca, este 
anúncio é um retângulo verde amarelado com um círculo e um losango emaranhados, mas que podem ser identificados, apresentando inclusive flores brancas que estão atrás das crianças, fazendo referência à faixa branca onde se lê: "Ordem e Progresso". O brinquedo colorido na mão da menina faz a vez da única estrela que se posiciona acima da faixa branca. Aí fica, mais uma vez, comprovado que a transparência da imagem - "embora seja só uma foto" - é realmente um mito.

Esse jogo de formas pode ser constatado, colocando-se o anexo 1 sobre 0 anúncio.

A opção dos anunciantes por colocarem as crianças em preto e branco se dá porque dessa forma ocorre uma modalização acentuada dessas figuras. Se estivessem também em cores, como o restante do anúncio, ficariam inseridas na paisagem. Da forma como estão, elas, além de estarem em primeiro plano, se projetam, como que para fora da 'tela', em direção ao leitor, fazendo com que este assuma de perto o lugar de participante do anúncio. Além de provocar um efeito de distanciamento das crianças em relação à paisagem que está por trás. Elas não se encontram soltas nessa imensidão. Estariam, isto sim, bem cuidadas.

Enquanto a BASF parece estar preocupada em se mostrar avançada quanto a seguir os preceitos de políticas afirmativas, ela não deixa de ser bem tradicional no que diz respeito ao papel dos personagens. As meninas continuam tendo seus olhares, seus interesses orientados para dentro do círculo, restrito ao mundo do interior ( do doméstico?) enquanto o menino olha para fora, para algo que não se pode ver o que é, para o desconhecido, lembrando que o lado direito, nessa sintaxe visual, indica o novo. Ele tem o mesmo olhar do personagem do anúncio alemão na neve, tão característico para o olhar masculino, como apontam Kress e van Leeuwen (2001). E como afirma Key (1990), a manipulação torna-se mais fácil quando não identificada.

A natureza indomada permanece longe desse momento idílico. As crianças se encontram em uma natureza controlada, representada por campos arados e saudavelmente verdes. Quando muito, vêem-se flores brancas a envolvê-los na paz. 
A imagem se impõe e se transforma em um texto escrito no momento em que passa a ser significativa e construir sentidos. Percebe-se, portanto, nessa imagem, a presença de formações discursivas de várias esferas. Subjaz a esse anúncio formações discursivas claras de patriotismo, de um mundo utopicamente pacífico, no qual todos são protegidos, sem problemas de etnias, de gêneros ou de idades. Todos sob a bandeira do Brasil. Existem formações discursivas que apresentam a BASF como complementar nesse cuidado que ninguém vê mas que se faz presente em todas as instâncias da vida, que aparecem imediatamente pelo logotipo e pelo próprio esquema do tipo de anúncio que se repete há anos.

\title{
Análise da composição lingüística
}

"BASF FAZ PARTE DO SEU DIA-A-DIA.

MAS SE A GENTE NÃO MOSTRAR, VOCÊ NEM PERCEBE."

\begin{abstract}
"Inovação e cuidado com o futuro. Essa é a fórmula que faz a empresa química líder mundial estar presente no seu dia-a-dia, da alimentação aos produtos plásticos.

Com soluções desenvolvidas para a nutrição humana, a BASF contribui para que seus parceiros tenham melhores colheitas e você, produtos de melhor qualidade em sua mesa. Com plásticos, a BASF colabora para um maior desempenho de inúmeros setores da indústria e para que produtos de melhor qualidade façam parte do seu dia-a-dia. Nas tintas, nos cosméticos, na lavoura da família Souza, no brinquedo das crianças e onde for possível contribuir para que seu mundo fique ainda melhor. Essa é a nossa química. A química da vida.'
\end{abstract}

"A BASF faz parte do seu dia-a-dia.

Mas se a gente não mostrar, você nem percebe". 
Recurso visual - para reforçar ainda mais a afirmação no título e no subtítulo do anúncio, seu criador faz uso de diferentes cores para cada enunciado. O título vem em preto, e o subtítulo, com a parte 'a gente' vem em verde e a parte 'você' em laranja, que são as cores predominantes na montagem do anúncio.

A forma sintática do título, em português, é extensa, apresentando elementos de coesão. O encadeamento dos enunciados é feito por ponto final e também por operadores argumentativos. O título assemelha-se a uma possível forma de começar a contar uma história, como: 'era uma vez um povo que não percebia o que existia a sua volta, até que um dia ...' O exordium propriamente dito é: "A BASF faz parte de seu dia-a-dia". E o restante é o que se convencionou chamar de 'título expandido' (Zielke, 1991). É a possibilidade de fornecer informações adicionais, já no título, além de, nesse caso, funcionar como um mediador para a introdução do texto.

"A BASF faz parte do seu dia-a-dia.

Fraseologismos - 'faz parte de' - é intrínseco à composição de algo - 'diaa-dia - seu cotidiano é feito por produtos da BASF'. Esses fraseologismos, mais a forma afirmativa como o enunciado é colocado provoca um índice de pressuposição. Entra como sendo parte de um acordo já estabelecido, como um fato sobre o qual não se discute mais, o que falta é o leitor ser conduzido a ver isso.

'Mas se a gente não mostrar, você nem percebe.'

Parafraseando o enunciado, este poderia ser: 'A BASF faz parte do seu diaa-dia, mas você nem (mesmo, não) percebe, portanto a gente não mostrar.'

Operador argumentativo - mas - e Operador de valor concessivo - nem reforçam-se. O locutor parte do pressuposto da validade da primeira proposição, coloca-a como sendo o argumento que deseja apresentar e, com o uso do 'mas' e do 'nem', anula-a com a finalidade de levar o leitor a uma conclusão diversa do que seria esperado: 'o que faz parte do dia-a-dia deve ser visto', mas na verdade não é. 
Há um índice de advertência, a culpa da não visão recai sobre o leitor. A condição para que seja percebida é apresentada no enunciado seguinte: 'a gente tem que mostrar'. O que é mostrado, porque não se vê, está no cotidiano, no 'diaa-dia' vivenciado inconscientemente pelos leitores do anúncio.

Esse título remete para o enunciado do anúncio alemão. Há um jogo entre invisível e visível, mas no enunciado brasileiro não aparece o par complementar Erfolg/sucesso. Ao contrário, os leitores brasileiros ficam restritos ao círculo seguro do cotidiano que é representado pelas crianças, pela forma com que sentam, pelas atividades desenvolvidas por elas, inseridas na natureza domada, que mantém a indomada ao longe, pelo contato com a terra e não com o céu.

O intuito do anúncio é conduzir o leitor - ao qual o locutor se dirige como 'você' - à conclusão de que ele é incapaz de perceber sozinho, sem a ajuda do locutor, que a BASF está presente, não é vista.

Operador condicional - se - a gente não mostrar 'isso' (a BASF faz parte ...), você nem percebe. O enunciado ligado ao operador 'se' encerra uma condição e o enunciado seguinte é a conseqüência. A condição é: 'se a gente não mostrar' e a conseqüência é: 'você não vê'. É uma conseqüência 'mediata' $(\mathrm{KOCH}, 1996)$ porque não existe nenhum termo comum entre os dois enunciados, eles se ligam por algum componente não expresso diretamente. Esse componente não expresso é a hipótese da qual o enunciador parte, que é a de que não somos capazes de perceber o que nos cerca no dia-a-dia, em se tratando dos produtos da BASF: 'A BASF está presente no dia-a-dia, mas você não é capaz de perceber, portanto, temos que ensiná-lo a ver.' Este seria o motivo didático da existência desse anúncio.

Fraseologismo - você nem percebe. Nem liga, nem percebe, não está nem aí ... O uso do pronome 'a gente' possibilita acionar o script de uma conversa coloquial na qual o fraseologismo: 'você nem ...' cabe muito bem. Ao mesmo tempo, o fraseologismo 'você nem percebe' evoca um script de queixa, como se algo injusto estivesse ocorrendo, um script de um relacionamento desigual, no qual uma das partes faz coisas 'demais' e a outra 'nem percebe'. Isso provoca uma intimidade da qual a BASF começa a fazer parte, como sendo a 'injustiçada', 
a que se esforça e não recebe o reconhecimento que the é devido. Consequentemente, o leitor está em débito, de maneira injusta, para com a BASF.

Começa a ser elaborado, no anúncio brasileiro, um ethos de humanidade, que é diferente do ethos de solidariedade. O primeiro implica posição assimétrica de empatia. Indica uma atitude de educador. A imagem discursiva, que começa a ser construída pela BASF, mostra o interlocutor desse anúncio como um indivíduo que necessita de alguém que thes indique o caminho, o que deve ser visto. A própria foto mostra crianças, representando um grupo que necessita do auxílio de educadores, em uma situação da qual perigo, situação de risco, ousadia, absolutamente não faz parte. Nosso aparato cognitivo começa a ser direcionado para scripts muito diferentes dos expostos em anúncios alemães.

No texto brasileiro, opta-se por um formato que se parece visualmente com um artigo de jornal. Possui o lead em negrito: 'Inovação e cuidado...', que já funciona como enumeratio, fornecendo a idéia sobre o que se vai falar. É seguido pelo corpo do artigo, que funciona como a argumentatio e digressio que se misturam, já que há uma tomada de posição pessoal dentro da argumentação: 'Essa é a fórmula ...' até 'ainda melhor'. A peroratio, o apanhado final que concisamente procura se ancorar na memória do leitor, predispõem o ouvinte afetivamente a favor da BASF: 'Essa é a nossa química. A química da vida.' Predisposição positiva que já foi estimulada fartamente com componentes imagéticos patrióticos e cuidados com infância.

"Inovação e cuidado com o futuro."

Nominalização - dos verbos inovar e cuidar. Se for usada a técnica de análise mencionada por Polenz (1985), poderia ser perguntado: Quem inova o quê, por quê e para quem? Quem cuida de quem? Quem necessita de cuidado? Por quê? Cuida em relação ao quê? Futuro de quem? Do anunciante? Do leitor? Do Brasil, que aparece tão claramente nas cores e nas formas embutidas?

Pelo fato de ser uma foto com crianças, supõe-se que inovação, futuro e cuidado com o futuro sejam em relação à infância. O que corrobora a imagem do Brasil como sendo o país do futuro. Cuidado com a natureza, por quê? Estamos 
destruindo a natureza? A inovação com cuidado para não agredir o futuro? As crianças?

As respostas devem ser construídas na mente do leitor, mas com certeza estarão vinculadas aos discursos construídos pelo locutor ao colocar os elementos, discutidos anteriormente, em cena. Patriotismo, infância, alegria, cotidianidade, segurança etc. Dessa forma, já vêm sendo acionados scripts que dêem conta desses sentidos, sem que haja necessidade de explicações ou maiores argumentações a respeitos de valores positivos com os quais a BASF deseja se ver ligada afetivamente no espaço mental do leitor. Como se pode perceber a carga de pressuposto e subentendido não existe apenas lingüisticamente, mas, também e boa parte, visualmente.

Índice lexical de avaliação - 'inovação' - pode ser visto como sinônimo do item lexical 'progresso', uma das palavras de plástico citadas por Pörksen, porém essa última ficou marcada com conotações nem sempre positivas. Até algum tempo, era quase sinônimo de 'sem limites'. E, na maioria das vezes, incluía a destruição do meio ambiente. Basta lembrar que o símbolo do progresso eram as chaminés expelindo fumaça para o céu.

Atualmente, a 'ordem do discurso', isto é, o que pode ou deve ser dito (Foucault, 2000) é outra. Fala-se em 'inovação, desenvolvimento sustentável, empresa solidária', selos do IBAMA acompanham quase todas as publicidades de empresas que são potencialmente poluidoras. Ou seja, as empresas têm que incorporar um discurso ecológico, de cuidado com a natureza, de solidariedade com o futuro.

'Inovação e futuro', na verdade, são palavras quase redundantes, já que, inovação implicita futuro, ou seja, toda inovação contém uma certa dose de futuro. Como progresso não inclui, necessariamente, cuidado, opta-se por termos mais modernos, que também têm amplo espectro, mas não têm conotações negativas. Indica também um ethos de liderança, pois inovação e futuro implicam a figura de um arauto (CHARAUDEAU, 2006, p. 153), um profeta a indicar o caminho para a comunidade, o que nos leva, novamente, ao ethos de humanidade. 
"Essa é a fórmula que faz a empresa química líder mundial estar presente no seu dia-a-dia"

O enunciado em negrito será repetido nos outros anúncios da série. Sempre o reforço da liderança da BASF entre as outras empresas do ramo e com sua onipresença no cotidiano brasileiro. A fórmula à qual se refere varia de anúncio para anúncio. Neste, é exposta a fórmula $\rightarrow$ Inovação $+(e)$ cuidado $=$ futuro.

Pressuposto - 'líder mundial' - manobra argumentativa embasada no pressuposto de que já é do conhecimento dos leitores uma informação que, na realidade, é justamente o que se deseja introduzir e ressaltar. Evita, dessa forma, possíveis discordâncias sobre o que esta sendo afirmado tão taxativamente. Quem está afirmando que a BASF é líder mundial? A afirmação da liderança da BASF é baseada em quê ou em quem? 'A BASF é líder mundial.' Daria margem a perguntas como: "Qual estatística demonstra que a BASF é líder mundial?" Da forma como está colocada, é difícil a negação, pois é introduzida por uma construção enfática.

Construção enfática - 'Essa é a fórmula que faz' - reforça a veracidade do pressuposto. Produz um ethos de competência e liderança, já que se trata de uma fórmula. Também forma um jogo de palavras que leva o leitor a lembrar que a da BASF é responsável por produtos químicos. São necessárias várias desconstruções para discordar desse enunciado. E a discordância seria em relação à qual enunciado? Que a BASF é uma empresa química? Que a BASF tem uma fórmula? Que essa formula a torna líder? Que a BASF é líder? Que ela está presente?

“... no seu dia-a-dia, da alimentação aos produtos plásticos”.

Da alimentação ao plástico = da agricultura às indústrias. Ou seja, quase tudo o que existe atualmente. Reforça seu discurso de onipresença.

A BASF contribui.../trägt...bei (com soluções/ Lösungen). A BASF colabora.../trägt ... bei. São as proposições principais, sinônimas, que norteiam a argumentação, introduzem as dependentes, ambas aparecem invertidas para que 
o foco de atenção recaia sobre o tipo de contribuição e colaboração que a BASF quer realçar. A argumentação é feita por intermédio da Classe argumentativa:

- "Com soluções desenvolvidas para a nutrição humana;

- "para que seus parceiros/Partner tenham melhores colheitas";

- "e (para que) você (tenha), produtos de melhor qualidade em sua mesa";

- "Com plásticos";

- "para' (que) um maior desempenho de inúmeros setores da indústria"; - - -

- "para que' produtos "de melhor qualidade façam parte do seu dia-a-dia."

Operador de causa e efeito - para que - essa é a relação de ligação entre os enunciados. É necessário que a primeira parte do enunciado seja verdadeira para que a conseqüência também seja. A insistência da BASF na argumentação de que ela contribui para essa melhoria é fundamental para a validade do discurso inteiro. O 'para que' é um operador que se repete nesse e em outros anúncios da empresa. Às vezes, claramente, e em outras, de forma velada. A causa é sempre a BASF com sua contribuição, soluções, e o efeito passa a ser os comparativos de superioridade: líder, soluções melhores, melhor qualidade, maior desempenho.

Índice lexical de avaliação

- soluções desenvolvidas - expressão com índice de avaliação meliorativo, já que inclui resultado positivo, isto é, os problemas já foram sanados. Constrói um ethos de competência, inteligência e seriedade já que implica empenho e conhecimento tecnológico, por se tratar de fórmulas.

- nutrição humana - o problema que necessita de soluções está aí: alimentação/agricultura, problemas de subsistência básica. Além de demonstrar um certo grau de erudição ao optar pelo termo nutrição. Ethos de inteligência, conhecimento.

- melhores colheitas, melhor qualidade, maior desempenho - trata-se de um uso comum do comparativo de superioridade na argumentação publicitária. Neste caso, usa-se o comparativo sem a presença de todos os termos de comparação. Funciona como um índice de polifonia. O locutor não diz que não há 
colheitas, qualidade ou desempenho sem a BASF, mas afirma que com a contribuição das soluções da BASF isso melhora.

Nominalização - desempenho - 'Para que alguém desempenhe um melhor trabalho'. Nesse caso houve um processo de nominalização, onde o agente responsável pela ação de desempenhar virou atributo de desempenho, além de ser diluído no anonimato de inúmeros.

Quantificador -"Inúmeros" - em contraposição ao líder, que é a BASF/ela. O recurso de colocar os parceiros no anonimato pela quantificação, também, é usado pela publicidade alemã '... wir als Partner vieler Industriezweige'/ 'nós como parceiros de muitos ramos industriais.'

contribui para melhor colheita, melhor qualidade - No anúncio alemão, como analisado, a BASF demonstra que trabalha em conjunto com parceiros e fregueses e, portanto, o ethos de solidariedade tem consequentemente um grande peso. Já no do Brasil a BASF aparentemente encontra/desenvolve as soluções sozinhas, e as oferece aos parceiros com a finalidade de contribuir para que estes melhorem as colheitas e os consumidores tenham melhor qualidade de vida.

Existe aí um reforço dos ethé de competência e de humanidade, pois os parceiros são apenas passivos ao receber o auxílio e não co-criadores das soluções. Na Alemanha, os parceiros da BASF participam ativamente e alcançam sucesso em sua parceria com a empresa. No Brasil, no entanto, os consumidores são meros espectadores dos processos da empresa, esperando, passivamente, a melhoria de sua qualidade de vida ao consumirem os produtos BASF.

"Nas tintas, nos cosméticos, na lavoura da família Souza, no brinquedo das crianças e onde for possível contribuir...'

Neste trecho, o anúncio traz para dentro do discurso os campos de atuação da BASF, fazendo referência subliminar a três instintos básicos da espécie humana, além de colocá-los em forma de uma classe argumentativa. 'A BASF colabora em':

$>$ tintas - tem a ver com moradia e remete ao instinto de 'guarida'; 
$>$ cosméticos - tem a ver com a sexualidade, desejo, e remete ao 'instinto de reprodução da espécie';

$>$ lavoura - tem a ver com a alimentação e remete ao 'instinto de sobrevivência'.

Com isso, o anúncio assegura que as necessidades básicas do ser humano serão supridas pela BASF do Brasil. Retoma a idéia do 'dia-a-dia' que foi mencionado no título. A Idéia da BASF ser onipresente.

Personificação - de todas as famílias em uma, a qual caracteriza com um nome familiar comum no Brasil: Souza. Reforça o ethos de intimidade, afetividade que já vinha sendo criado a partir do uso de 'você' logo no título. No momento em que se dá um nome real a uma família fictícia que, na verdade, faz parte de um anúncio publicitário, este adquire maior força, como se essas pessoas existissem fora da narrativa publicitária. Funciona como um índice de autoridade, não com pessoas famosas, mas supostamente com famílias reais, de nosso cotidiano, esse cotidiano tão importante para a BASF.

- no brinquedo - continua a estratégia de listar argumentos em classe argumentativa. Depois dos três instintos básicos supridos, é possível o lúdico. As crianças da foto, e o 'cuidado com o futuro' do início do texto são resgatados e atualizados nesse argumento. Caberia nessa argumentação o operador 'até/ inclusive' dando a idéia do argumento de 'lambuja' do qual nos fala Koch (1996). A BASF se preocupa 'até' com os brinquedos das crianças, coisa que parece 0 menos importante nessa escala de argumentação.

Em relação aos brinquedos que as crianças têm nas mãos, vale a pena chamar a atenção para o fato de que os brinquedos nas mãos das meninas são claramente brinquedos femininos, um deles com a cor laranja para a qual a BASF chama atenção e outro em tons cinzas. O brinquedo que está na mão do menino aparece difuso, sem que o leitor possa saber se é um brinquedo típico de menino ou de menina.

Operador argumentativo de copulação - e - usado para organizar a listagem da classe argumentativa. 
Classe argumentativa - onde for possível contribuir... Atua como a peroração do que foi estabelecido acima. Funciona como um índice de honestidade. Um arremate para cobrir possíveis campos que não tenham sido tratados no anúncio. Ao mesmo tempo, institui o ethos de honestidade, colocando um limite em seu raio de atuação, já que não quer dar a idéia de poder absoluto, o que poderia parecer desonesto.

"para que' seu mundo fique 'ainda' 'melhor".

Operador argumentativo de causa e efeito - para que - novamente. A BASF aparecendo como a causa que provoca um efeito positivo: 'seu' mundo melhor.

Operador - ainda - que pode ser temporal e não-temporal. Aqui ocorre a última possibilidade. Soma argumentos como um reforço a favor de uma mesma conclusão. No caso acima, o que foi desenvolvido ao longo da classe argumentativa: a BASF melhorando 'ainda' mais sua vida. Existe também um pressuposto: o de que a vida dos leitores do anúncio é boa, mas com a BASF é melhor.

Inscrição do sujeito no discurso - O título introduz o dêitico 'a gente' que, a princípio parece ser a BASF, assumindo a mesma postura que nos anúncios alemães, nos quais o uso do 'nós' aparece tão claramente. A partir do lead do anúncio percebe-se a existência de um locutor responsável pela fala contida no texto, autorizado pela BASF a falar em seu nome, e que se refere a BASF como 'ela', em terceira pessoa. A BASF passa a ser o referente sobre o qual o locutor constrói seu discurso. Os verbos estão todos na terceira pessoa: ela faz, contribui, colabora. Este locutor determina ao leitor o lugar de 'você', o outro, nesse contexto do anúncio: '...seu dia-a-dia (essa expressão ocorre três vezes) '...você nem percebe', '...seus parceiros...', '... você, produtos ... - ', '...seu mundo...'.

Porém, no final, esse locutor que a princípio mantém distanciamento, revela-se como sendo também a BASF: 'Essa é a nossa química'. O locutor busca, dessa forma ambígua, pois agora é a BASF que fala sobre a BASF, ocupar todos os possíveis espaços para persuadir o leitor. 
Em publicidade, essa ambigüidade, essa mistura de vozes no mesmo texto, em nenhum momento é considerada negativa, ao contrário, isso pode ser capitalizado como uma “... estratégia para uma tentativa autoritária de açambarcar todo o espaço discursivo e conduzir o processo de preenchimento do texto pelo leitor" (BRANDÃO, 1991: 459).

$\mathrm{Na}$ verdade, a BASF faz um discurso no qual é difícil determinar quem é que fala e de onde se fala. $O$ fato de haver mais de um sujeito como construtor desse discurso provoca um efeito de dispersão, com várias vozes concorrendo para construir o mesmo sentido e tentar conduzir a uma conclusão desejada.

Além de haver esse efeito, provocado pela não delimitação do sujeito, essa forma de dêitico pronominal 'a gente', 'nossa' é um 'nós excludente', sobre o qual já foi discutido e que provoca o efeito de um paraíso de igualdade entre os diversos tipos de trabalhadores que fazem a BASF. É essa 're-engenharia lingüística' usada para apagar sinais de conflitos.

Nos anúncios alemães, a construção da identidade da BASF fica clara pelo uso recorrente de 'nós', que a BASF opta por assumir na instância de seu discurso. Nesses, o sujeito autorizado a falar sobre a BASF e a BASF são coincidentes. Nos anúncios brasileiros essa coincidência não ocorre. Isso provoca a construção de alguns ethé divergentes.

No caso Alemão, proporciona, um ethos de solidariedade, pois o 'nós', mesmo que excludente, fornece a idéia de uma certa concordância de pontos de vista e uma responsabilidade conjunta no gerenciamento da organização social. Um ethos de poder que tem que ser dividido entre outros participantes.

Enquanto, no Brasil, o peso maior vai para o ethos de humanidade. A BASF se coloca como o referencial sobre o qual se fala e como uma força alheia à comunidade. Funcionando de maneira paternalistica, auxilia, facilita o seu dia-adia. Isso fica mais claro ainda no próximo anúncio. Demonstra atuar em uma comunidade ainda sem condições de resolver os seus problemas básicos, muito menos de experimentar os atos audazes de heróis viris. Por esse motivo, as imagens escolhidas para os anúncios brasileiros remetem a famílias. 
"Essa é a nossa química. A química da vida."

Figura retórica de repetição - Há um jogo feito a partir da anadiplose. Nesse caso, o elemento repetido deve vir no final da frase anterior e no início da posterior (SPANG, 1987), como acontece com termo 'química'. Isso não é, apenas, uma questão de estilística, mas uma contribuição argumentativa para a criação de várias leituras. Com esse recurso conduz-se o leitor à lembrança de que:

1- a BASF é uma empresa de produtos químicos;

2- a repetição da expressão enfática - 'essa é' - retoma a expressão que surge no início do anúncio com - 'essa é a nossa fórmula' - também reforça a idéia de uma empresa química;

3- fraseologismo - mas a BASF não é apenas algo 'frio e distante' como uma empresa, ela liga-se afetivamente ao leitor por intermédio do fraseologismo: 'nossa química', usado, nesse caso, para trazer a idéia ou sensação de que a BASF e o leitor se entendem, trabalham bem conjuntamente, têm a mesma química. O pronome 'nossa' tenta construir o sentido de incluir o leitor e a BASF nesse grupo de intimidade;

4- se tirarmos a expressão enfática resta a frase: 'a nossa química, a química da vida' ou 'a nossa química 'dá' vida'. Trabalha como um slogan no espaço mental do consumidor, retomando o título: 'a nossa química dá vida e você nem vê'. Que injustiça.

Inventário perceptual mitológico -

Nesse anúncio, a BASF, ao tentar demarcar, fortalecer um espaço mental para sua marca, procura ligar-se afetivamente aos leitores, buscando na figura mitológica da Grande Mãe (RANDAZZO, 1997, e CAMPBELL, 2002). A Grande Mãe onipresente, mantendo acessa a chama de seu lar, sinal de vida para sua família, sempre cuidando de seus filhos. Cuidado que abrange, "na medida do possível", todos os segmentos da vida, como é constantemente afirmado por ela. 
Trata-se de uma figura, com a qual seus filhos podem contar e confiar incondicionalmente. Ele nada exige, apenas está à disposição de sua família, sempre presente para seus filhos, que recebem tudo que ela oferece sem ter que dar nada em troca - 'E você nem percebe'.

É uma recepção passiva, não ameaçadora, daí as imagens serem idílicas, realçando a estrutura familiar, que, por sua vez, simboliza a proteção fornecida pela BASF. A Grande Mãe cuidadosa, de uma família coesa, e que só pensa em trabalhar para os filhos. Imagem arquetípica de proteção, paz duradoura, eterna, contida em desejos infantis, que acham que nunca vão se separar de suas famílias.

O mundo como um ovo, protegido pela casca que a BASF oferece, representado visualmente pelo círculo formado pelas crianças sentadas, reforçado subliminarmente pelos elementos patrióticos que se descortinam quando analisados os vetores e os matizes. A Pátria como a Grande Mãe que protege ou deveria proteger a todos. A BASF e a pátria brasileira, nesse momento, têm seus papéis emaranhados, subliminarmente.

Outro item/conteúdo do inventário perceptual desse anúncio, com o qual a BASF tenta se ancorar na mente do consumidor/leitor, é apresentar a BASF como responsável pela criação de um mundo puro, limpo e sem problemas. E quando, porventura, houver problemas, ela estará presente 'onde for possível contribuir'. Ou seja, a BASF está sempre empenhada em encontrar soluções para melhorar a vida dos indivíduos, tornando seu viver um possível paraíso de paz e pureza, evocado pela composição da imagem.

$O$ arquétipo do paraíso perdido por faltas humanas é resgatado pela atuação responsável e maternal da BASF, com suas 'contribuições, soluções, desempenho, inovação', em todos os segmentos da sociedade. Um paraíso onde também não há problemas de gênero ou de cor. Onde a diferença é respeitada.

\section{Conclusão parcial}

É fácil demonstrar a estratégia argumentativa ou a intenção de conduzir o leitor para a conclusão desejada, fazendo o caminho inverso e transformando as 
nominalizações em verbos: 'a BASF 'inova, cuida, é líder/é única, está (presente), soluciona, desenvolve, contribui, melhora, colabora'.

Complementado com uma argumentatio feita pela classe argumentativa, em torno de instintos básicos de sobrevivência. Não são citados feitos audaciosos. A figura da Grande Mãe, que não exige desempenho de seus filhos, apenas os ama, surge de maneira quase absoluta. Apresenta crianças, em primeiro plano, o que as modaliza como sendo importantes. Esta imagem, analisada acima chama a atenção pela sensação de segurança que sugere. Estão cercadas das cores verde-amarelas e de outros elementos que lembram a bandeira brasileira.

As cores tendem ao tom pastel, que evoca a idéia de algo etéreo, como se elas estivessem em um sonho, mas, ao mesmo tempo, na terra, são reais. Aparecem juntamente com os termos meliorativos como: inovação, cuidado, futuro melhor etc., assim como os verbos 'contribui' e 'colabora'. Isso tudo funciona como modalização em favor da empresa anunciante. Buscam fortalecer a idéia da importância da existência e desempenho da BASF, assim como se ligar afetivamente, a partir de uma idéia de paraíso, ao espaço mental do leitor.

O anúncio brasileiro constrói sentidos como: a BASF é responsável por contribuições, soluções - ethos de competência, seriedade, inteligência - para problemas, que melhoram, cuidam de sua vida; - ethos de humanidade e solidariedade, com peso maior no primeiro, a partir não só da imagem de crianças, que evoca, no imaginário, a sensação de que alguém cuida delas, como um invisível anjo da guarda, como, também, lingüisticamente: melhores produtos, comidas, plásticos, brinquedos. Contrói um ethos de poder, pois estão em todas as instâncias da vida comunitária.

A conclusão é que crianças necessitam de cuidados, como também os leitores, os usuários de produtos da BASF, que são, por sinal, um dos vértices do losango. A BASF se encarrega de cuidar das pessoas, além de pegá-las pelas mãos e mostrar-lhes o que não conseguem ver, isto é, o quanto a BASF é importante - ethos liderança.

Se a princípio a BASF reluta por se mostrar dona de seu discurso, isso ocorre no final do anúncio, com a retomada do discurso pela BASF com o 
enunciado: 'Essa é a nossa química', encimando o logotipo da empresa, que funcionaria como a assinatura no final do anúncio: A BASF carimba embaixo. Esse índice de polifonia funciona como um recurso de autoridade, da mesma forma que o emaranhado de elementos visuais patrióticos, colocados subliminarmente.

Essa ambigüidade do sujeito inscrito no lingüístico, esse 'nós' final, a constante afirmação de onipresença, o emaranhado visual com o uso de elementos que exploram os sentimentos patrióticos, tudo converge para a idéia de que a BASF e o Brasil se misturam, tanto na composição visual do anúncio como na lingüística. Esse discurso híbrido, no qual se fazem presentes várias formações discursivas, esse sujeito diluído em várias formas de inscrições, que provocam essa ambigüidade, em nenhum momento é negativo, pelo contrário, dessa forma a BASF procura ocupar todos os espaços de persuasão de forma a conduzir o processo de criação de sentidos pelo leitor.

A mitologia latente nesse anúncio ultrapassa o que a BASF anuncia a respeito do que produz e para que serve. Usa esses elementos subliminares para criar scripts de afetividade e de como os leitores desejam ver-se, fazendo parte de uma comunidade chamada Brasil, feliz e bem cuidado, onde apenas as características positivas e desejáveis tomam todos os espaços de significação e onde todos se mantêm à espera de alguém que cuide de tudo. Tudo será resolvido ou pela BASF ou pelo Estado, ambos ambiguamente interligados como uma Grande Mãe a cuidar de seus entes queridos.

A conclusão é uma avaliação axiológica apreciativa, como uma verdade de valor moral, inquestionável, propagada pelo anúncio, do tipo: "A BASF é útil à família brasileira, ela é importante para uma vida ainda melhor, feliz e pacífica, ela se preocupa com a família brasileira, com os rumos do Brasil." Assim como o Estado brasileiro, simbolizado pelas cores e formas da bandeira. Louva-se a BASF assim como louva-se pátria. Coisa comum em publicidade ou propaganda. 


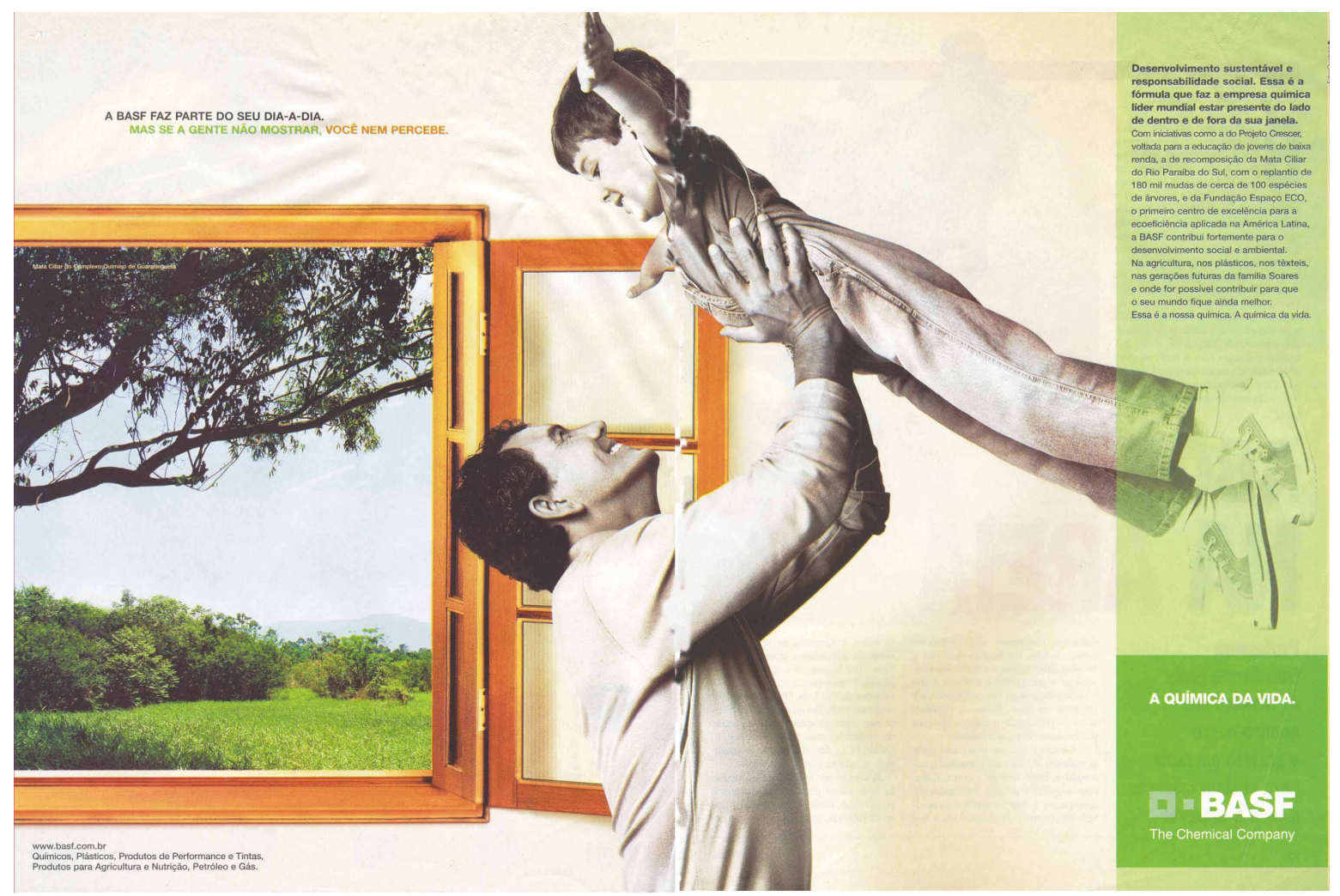




\subsection{Anúncio veiculado na revista Veja de 28-12-2005}

Análise da composição visual do anúncio - Foto ao centro: uma janela aberta para o verde, através da qual se vê um gramado e, logo atrás, uma mata um pouco mais densa. Dentro da casa, que tem as paredes em tom amarelo claro, meio esverdeado e meio esmaecido, vê-se um homem que levanta um menino acima de sua cabeça. Isto evoca automaticamente o script de pai, filho, família, lar etc. O menino brinca, de braços abertos, confiante de que não vai cair. Eles estão em primeiro plano, colocados bem no centro do anúncio o que funciona como uma modalização da importância que se dá aos dois. Como no anúncio anterior, também estão em branco, preto e gradações de cinza.

Do lado direito uma coluna translúcida, com fundo verde claro e escuro. $\mathrm{Na}$ parte verde clara, está o texto maior em negro, no mesmo esquema formal do anúncio anterior. Embaixo, no quadrado em verde escuro, as letras são grafadas em branco.

Quanto aos vetores, um é representado pelo menino, a cabeça indica o exordium, os pés se dirigem para o centro do retângulo verde, o calcanhar se dirige para o corpo do texto, acima e as pontas dos pés, para o logotipo. A parte do ombro do braço do pai que segura o menino, parece fazer uma curva. Os ombros indicam para os produtos da BASF e os cotovelos para o corpo do texto.

Mas se começarmos, novamente, a unir as linhas que definem as imagem, teremos outra imagem que nos chega subliminarmente. Através da janela, vemos dois galhos de arvores e uma floresta que também podem ser identificadas como linhas. O galho mais grosso, acima do mais fino, pode ser unido com o corpo do menino, cuja cabeça, mais uma vez, como no anúncio anterior, é o vértice superior de um losango. Este galho tem uma extremidade que se une, à esquerda, num ponto fora do ângulo de visão do leitor, com a mata que, por sua vez, funciona como a linha inferior do losango que vai, até a axila da figura paterna.

A partir daí, nosso cérebro pode preencher as lacunas que faltam, da mesma maneira que preencheria lacunas se fosse um texto lingüístico e, portanto, pode perceber uma linha que segue até os pés do menino, completando o losango 
que nos é tão familiar como brasileiros. Mesmo por que o braço do pai indica para essa direção. Se completarmos a curva iniciada pelo braço do homem, veremos um círculo dentro desse losango. O braço direito do menino introduz mais um elemento desse círculo. E se prestarmos mais atenção, encontraremos uma faixa curva que corta esse círculo, formada pelo galho inferior e a divisória superior do postigo de vidro.

Essa conjunção de formas pode ser, mais uma vez, constatada com uso do anexo 2 .

O único elemento que, desta vez, não aparece é algo que signifique a solitária estrela acima dessa faixa, para que fique semelhante à bandeira brasileira. À semelhança do anúncio anterior. Os únicos elementos que o cérebro necessita completar nesse desenho é a linha inferior da direita e pouco mais da metade do círculo da esquerda. Quanto às cores, elas estão meio embaralhadas, mas estão presentes no anúncio: verde, laranja e amarelo. As cores dos seres humanos serão fornecidas provavelmente com tintas e produtos da BASF.

Análise da composição lingüística - o exordium segue o mesmo padrão do anúncio anterior, da mesma forma que nos anúncios alemães. Funciona como uma fórmula de reconhecimento para vários anúncios da empresa, sem a necessidade de gastar tempo, o que é essencial dentro da rapidez com que os anúncios devem atingir a atenção do consumidor. Eles só se diferenciam quanto ao texto no lado superior direito.

\section{Texto:}

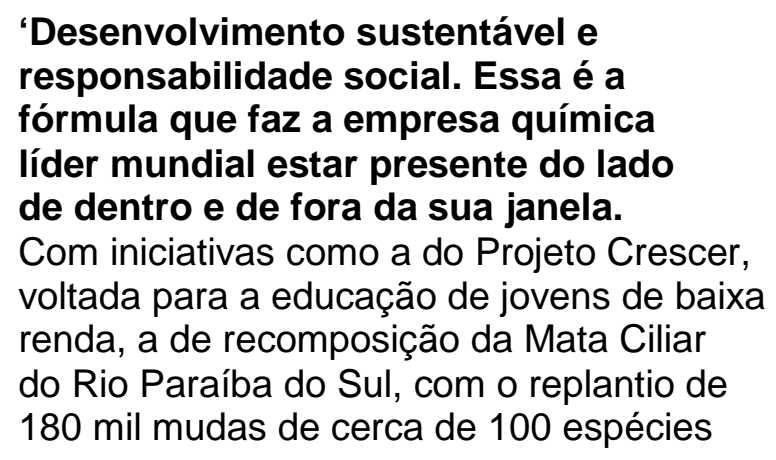


de árvores, e da Fundação Espaço ECO, o primeiro centro de excelência para a ecoeficiência aplicada na América Latina, a BASF contribui fortemente para o desenvolvimento social e ambiental. Na agricultura, nos plásticos, nos têxteis, nas gerações futuras da família Soares e onde for possível contribuir para que o seu mundo fique ainda melhor.

Essa é a nossa química. A química da vida.'

"Desenvolvimento sustentável e responsabilidade social".

Palavras de plástico na forma de um fraseologismo - desenvolvimento sustentável remete ao início do anúncio anterior: 'cuidado com o futuro'. De maneira semelhante, faz a ponte entre a empresa BASF e o futuro das famílias e para seus filhos. Esses elementos lingüísticos são veiculados como um reforço à argumentação feita visualmente. No outro, as crianças; neste, pai com filho.

Como já foi dito anteriormente, 'desenvolvimento' é uma das palavras de plástico, citadas por Pörksen (1997), ao qual, aparentemente, está sendo acrescentada outra palavra com tendência a se tornar de plástico: 'sustentável'. A ciência se apossa de termos do cotidiano, como 'sustentável', e as devolve ao diaa-dia, só que com aura mais poderosa. Esse fraseologismo é um termo muito citado atualmente, mas de tão amplo espectro que não se sabe exatamente a que se refere. Mais parece uma forma de não ter que discutir as causas do nãodesenvolvimento.

Da mesma forma, pode-se referir ao termo 'responsabilidade social'. Em todo caso, é um discurso muito atual, não só no Brasil, como em países com melhor distribuição de renda. Outra característica dessa expressão, como frisa Polenz (1985: 33) é que ela segue a tendência a condensações de frases em nomes e atributos, uma forma de 'despessoalizar' a expressão. A expressão quer dizer: 'um desenvolvimento que seja capaz de sustentar-se por si próprio.' Acontece aí um processo de apagamento de possíveis sujeitos atuantes no processo. O desenvolvimento se sustenta ou existem pessoas que são responsáveis por algum tipo de atividade que proporciona a sua própria mudança 
ou da comunidade tanto para melhor quanto para pior? Resta perguntar, desenvolvimento para onde, para quem, a que custo?

Um artigo na revista alemã DER SPIEGEL número 31/2005 já afirma que, com o intuito de vender seus produtos, as empresas descobrem cada vez mais "sua veia social" e apelam para a "boa consciência" de seus fregueses. Esse artigo afirma: "Bebedores de cerveja salvam florestas tropicais e fãs de chocolate doam quadros-negros para crianças africanas". Essa matéria tenta enfatizar a nova estratégia das empresas para alavancar suas vendas: vincularem seus negócios a ações politicamente corretas e de alcance social.

A BASF do Brasil, também, se adequa a esse discurso ecológico e social, assim como outras empresas brasileiras e não brasileiras, como Natura, Boticário, Coca-cola e outras. A maioria traz em seus anúncios selos identificadores do IBAMA (recursos naturais), INMETRO (respeito às normas de segurança do consumidor), PROCEL (baixo consumo de energia elétrica), Fundação ABRINQ (empresa amiga da criança), ISO 14000 (respeito ao meio ambiente) etc. Tais certificados atestariam a natureza politicamente correta da empresa, da mesma forma que Ihes trariam mais fregueses.

Operador de conjunção - e - soma os argumentos positivos em benefício de uma conclusão, que no caso é a acentuação da participação da BASF no cuidado com a sociedade na qual atua. Dessa forma, proporciona a construção de vários ethé, tanto de credibilidade pela seriedade e competência que aparenta, quanto de afetividade, levando à identificação como ethos de humanidade e solidariedade. A BASF mostra-se preocupada com as pessoas, com o meio ambiente e com a sociedade. E a construção discursiva segue nessa linha, acumulando argumentos, como esses, em classe argumentativa.

"Essa é a fórmula que faz a empresa química líder mundial estar presente..."

Repetição do enunciado do anúncio anterior, porém essa 'fórmula' remete, agora, a outras atividades: "educação de jovens de baixa renda", "recomposição 
de Mata Ciliar" etc. que deixam vislumbrar um mundo não tão em ordem como o do anúncio anterior.

"... do lado de dentro e de fora da sua janela."

Fraseologismo - do lado de dentro e de fora - Novamente a onipresença da BASF é demonstrada, pois, "dentro e fora da sua janela" significa estar em todo o lugar. Ethos de poder, capaz de organizar e proteger todo o espaço onde o indivíduo se encontra. Ele se dirige a 'você' através do pronome 'sua'. A forma de inscrever-se e inscrever o interlocutor no discurso é a mesma analisada no anúncio anterior. Chama o seu interlocutor para a intimidade de sua casa, protegida pelas paredes pintadas com tintas que levam produtos da BASF e para o desconhecido que está 'fora' das paredes, mas da mesma forma protegido pela BASF.

A imagem colocada neste anúncio é a de um homem com um garoto que seria seu filho. Tal imagem difere da dos anúncios veiculados nos anos anteriores, onde o mais comum era mostrar uma mãe brincando com seu filho. Mas o inventário perceptual continua sendo o de uma figura protetora. A natureza do lado externo, próxima à janela é uma natureza domada, controlada (pelos insumos agrícolas da BASF, presume-se).

Com iniciativas como a do Projeto Crescer, / voltada para a educação de jovens de baixa renda, a de recomposição da Mata Ciliar / do Rio Paraíba do Sul, com o replantio de 180 mil mudas de cerca de 100 espécies / de árvores, e da Fundação Espaço ECO, o primeiro centro de excelência para / a ecoeficiência aplicada na América Latina, a BASF contribui fortemente para o / desenvolvimento social e ambiental.

Modalização - O complemento que são as formas de colaboração da BASF foram colocados diante do sujeito e verbo, ao invés de vir depois deles que é o modo não marcado, também em língua portuguesa (Martins, 1989). - 'A BASF contribui fortemente 'com iniciativas ( como a...) para (que) ...' - Esse recurso provoca a mudança do foco para as atividades desenvolvidas pela BASF, provocando uma ênfase em sua atuação engajada no desenvolvimento social e ambiental. Além disso, com esse procedimento, os referentes, 'social e ambiental', 
são igualados. O processo de naturalização de ações humanas para o qual Barthes (2003) chama a atenção, torna-se tão claro que podemos perceber o enunciador igualando 'social' e 'ambiental', como se tanto a sociedade como o meio-ambiente fossem lugares onde a BASF atuasse para melhorar o cultivo.

Classe argumentativa - A estratégia de argumentação usada continua sendo a classe argumentativa para expor suas atividades como possibilitadora da melhora de vida de grupos carentes e do meio ambiente já destruído. Os argumentos parecem vir como apostos, encadeados por sinais ortográficos vírgulas - e arrematado pelo operador conjuntivo - 'e' -, na realidade, são complementos de 'contribui com'. Realçam-se as 'iniciativas'.

"Com iniciativas como:

1 - a do Projeto Crescer;

"voltado para a educação de jovens de baixa renda";

2 - a de recomposição da Mata Ciliar do Rio Paraíba do Sul,

> "com o replantio de 180 mil mudas de cerca de 100 espécies de árvores".

- e - os argumentos estão em ordem crescente de importância, deixando para o final o que impressiona mais, utilizando, inclusive, termos científicos inacessíveis à maioria dos leitores.

3 - "...da Fundação Espaço ECO, o primeiro centro de excelência para a ecoeficiência aplicada na América Latina.

Modalização pelo índice lexical de avaliação - 'desenvolvimento sustentável', 'recomposição da mata ciliar', 'Fundação Espaço ECO', 'centro de excelência', 'ecoeficiência', 'aplicada' são termos lexicais que fazem parte do domínio do discurso científico e provocam um certo estranhamento em pessoas não acostumadas ao seu uso. A utilização de termos científicos pode ser vista como um índice de avaliação positiva (Martins, 1989), já que pertencem a um campo de atuação respeitado, composto de especialistas.

Graças a essa inserção de discurso científico, o texto publicitário adquire um caráter mais sério e as atividades da BASF parecem muito mais importantes. 
Constrói-se, dessa forma, ethé de idoneidade, competência, liderança e poder. Ocorre, por intermédio desse artifício, um 'renomeamento de realidades' e termina-se com uma linguagem 'comodificada'. Existem vocábulos que, quando usados em campos que lhes são estranhos, passam a causar admiração, já que a maioria das pessoas não consegue decifrá-los.

Operador de encadeamento causal - para / para que -, vai da causa para a conseqüência. Como em outros anúncios, a BASF se diz a causa, e o desenvolvimento ocasionado por ela seria a conseqüência. Não se fala de sucesso e sim de sobrevivência, pois as comunidades são carentes, o meio ambiente encontra-se em perigo e a solução quem fornece é ela, com o primeiro centro de ecoeficiência.

Modalizador de contribuição - fortemente - Os termos retomados, além de não serem mais tão vagos como na introdução, sofrem mais uma especificação: o modalizador 'fortemente'. A atuação, o engajamento da BASF vai além das expectativas.

A inversão também ocorreu em função do próximo argumento. O enunciado seguinte se apóia no verbo 'contribui' do enunciado anterior, embora venha delimitado pelo ponto final, esse verbo é atualizado como um infinitivo.

(A BASF contribui/investe) "Na agricultura, plásticos, têxteis e "nas gerações futuras da família Soares e onde.."

Classe argumentativa - a BASF contribui 'fortemente' para o:

- Na agricultura,

- nos plásticos,

- nos têxteis,

- $\quad$ nas gerações futuras da família Soares

Mais uma vez percebemos a estratégia de considerar como iguais o ambiental e a instituições da sociedade.

'e onde for possível contribuir para que o seu mundo fique ainda melhor.'

A partir daí retoma o que é dito em outros anúncios, fortalecendo a conclusão preparada pela classe argumentativa, que vem a ser o slogan 
expandido, com a introdução do pronome 'nossa'. A 'nossa' química é a química da vida. O que deixa subentender que 'a dos outros não, a nossa sim'. 'Essa é a nossa química. A química da vida'.

\section{Conclusão parcial}

A conclusão, a ser feita pelo leitor, continua sendo de acordo com a estratégia do anúncio em realçar a importância, a competência, a liderança, a confiabilidade e a onipresença da BASF. Nesse ponto, o anúncio se iguala aos publicados na Alemanha e continua mantendo a linha dos outros anúncios da empresa, publicados no Brasil, anteriormente a 2005.

Porém, no Brasil, procura-se chegar a esses ethé, acionando, no leitor, o script da estrutura familiar, através de ilustrações com figuras paternas, figuras de crianças, casas, aparentemente bem arrumadas e cuidadas, nas quais as pessoas nunca estão sós, mas rodeados de outras que seriam seus familiares. Essa família continua sendo batizada com sobrenome tradicional brasileiro: Soares, funcionando como índice de autoridade.

O mundo idílico do anúncio anterior deixa entrever um mundo problemático. Nesse anúncio, há o relato sobre projetos para salvar o meio ambiente que se encontra ameaçado. Além disso, existem ainda indivíduos com renda que aparentemente não é suficiente para suprir o necessário: 'jovens de baixa renda', embora não fique claro o que é esse necessário, pois a 'relexicalização', como bem chama a atenção Fairclough (2001, 1999), renomeia um fenômeno problemático, mudando relações de percepção, sem que os conflitos anteriores sejam, necessariamente, resolvidos.

Ao mesmo tempo, a BASF se apresenta como a Grande Mãe que está sempre presente e se propondo a encontrar soluções para esses problemas. Elabora uma ethos de humanidade, sentimento de solidariedade inspirada por relações assimétricas de poder e atuação. Com seu desempenho científico a favor de seus filhos, cria 'centros de excelência', outro termo comodificado, que impresiona por não definir o que deve ser entendido com seu uso. 
Parte do texto impressiona pela dificuldade de compreensão que as palavras podem provocar em um leitor menos desaisado, pois são termos que vêm de áreas científicas, criando uma respeitabilidade acima do esperado para um texto publicitário. Dessa forma, constrói, lingüisticamente, um ethos de competência, inteligência, onipotência, seriedade.

A estratégia de argumentação se repete, o que é compreensível, pois sendo um texto publicitário procura enumerar suas características positivas. A estratégia é feita, principalmente, através da classe argumentativa, sempre enumerando as boas ações da BASF junto ao seu público, assim como sua importância para 'melhorar' a qualidade de vida de todos. Os termos de avaliação axiológica continuam parecidos com os do primeiro anúncio: desenvolvimento, responsabilidade, líder, iniciativas, gerações futuras. O verbo contribuir é o que mais tem peso dentro do anúncio, o que conduz à conclusão da grande importância da BASF como algo que "faz parte do dia-a-dia".

Iguala o social com o ambiental, ao anunciar seu auxílio. Essa igualdade é criada por intermédio do uso da classe argumentativa, que lista seus argumentos como tendo os mesmos valores e, portanto, provocam a naturalização de relações, que são históricas, frutos de embates sociais de grupos com posições antagônicas e não elementos da natureza.

Pode-se afirmar, com base no que foi desenvolvido sobre cultura de massa e arquétipos, que as imagens das famílias apresentadas pela BASF brasileira, são idealizadas, pasteurizadas, a partir das imagens arquetípicas de família e proteção. $\mathrm{O}$ arquétipo da estrutura familiar é picotado em um clichê piegas, num repetitivo script de felicidade, com imagens estereotipadas, empobrecidas com a perda do todo, que é a teia de significações que compõem o mito arquetípico.

Parece assumir como válido o que diz Tolstoi logo no início de seu livro Ana Karenina: "Todas as famílias felizes se parecem entre si; as infelizes são infelizes cada uma à sua maneira" (TOLSTOI, 1984, p 9). O que temos na publicidade brasileira em questão é essa simplificação matemática do arquétipo de proteção, por intermédio de uma estrutura familiar, num estereótipo do que deveria ser uma família, de acordo com o inventário perceptivo, que segundo os produtores do 
anúncio, seja mais consonante com a sociedade brasileira. Contém, apenas, facetas simples e cotidianas das relações familiares, deixando transparecer apenas a felicidade piegas, imposta por meio de repetições, e ao qual essa BASF deseja ser vinculada afetivamente.

\subsection{Comparação entre as publicidades da BASF}

Os dois primeiros anúncios alemães exploram paisagens amplas, sem moldura, dando idéia de que os personagens não têm limites, tudo é possível, desde que estejam com os produtos da BASF. O jogo da iluminação é um aspecto que muito contribui para esses sentidos contidos nesses anúncios, pois os raios sempre indicam o caminho do céu, do infinito, do etéreo, do futuro, nada pode parar esses indivíduos.

As dificuldades que thes são impostas vêm representadas por fenômenos atmosféricos ou geográficos a serem, ao que parece, voluntariamente vencidos. Parece haver o estímulo à audácia individual por intermédio dessas imagens. Começam a ser construídos, visualmente, características de coragem e potência por parte dos usuários de produtos BASF alemã, pois estimula-se a figura do herói contemporâneo.

Por intermédio da inserção estratégica do exordium, já vão sendo construídas qualidades como competência tecnológica e solidariedade por parte da BASF, coragem e audácia por parte dos leitores. Essas características vão ser confirmadas e reforçadas lingüisticamente. Desse cruzamento de olhares, surgem os ethé desejados pela BASF, tanto para si quanto para seu possível interlocutor.

A imagem do terceiro anúncio alemão, em comparação com os outros dois, surge com maior ambigüidade. Só podemos entender que, por ser representada uma personagem feminina, não lhe cabe o papel de herói tradicional. Esta figura é construídacomo algo a ser protegida, pois é colocada em uma moldura que the permite muito pouco ou nenhum espaço de ação. Não existem raios a indicar o infinito celeste para que seja conquistado. Seu limite é muito claro. Nisso ela se 
assemelha às publicidades da BASF brasileira, mas em contraposição a estas últimas, o ethos de humanidade não é o item que a BASF cria para si nesse contexto.

Ambiguamente, surge um ethos de vulnerabilidade que coloca a personagem como estando à disposição dos componentes masculinos, representados pelos elementos fálicos que a rodeiam. Os elementos subliminares nesse anúncio são sexuais e não patrióticos. Ao mesmo tempo, ela parece aceitar esse jogo, com seu sorriso enigmático, mantendo-se impassível, criando um ethos de autonomia, displicência, dentro desse espaço que lhe é destinado, o da sedução e não para realizar grandes feitos. O ethos de potência parece ficar por conta da BASF que fornece aos produtos o 'priapismo' contido nesse anúncio.

No caso da primeira publicidade brasileira da BASF, a imagem é composta, aparentemente, sem moldura, mas as crianças encontram-se sob o controle dos interlocutores, pois estes funcionam como o vértice inferior que falta ao losango patriótico. Ao mesmo tempo, o gramado bem cuidado e a mata que se delineia ao fundo funciona como uma moldura que limita esse espaço de ação. As crianças encontram-se em um ambiente domado por produtos da BASF.

A imagem do segundo anúncio também aparece, claramente, emoldurada e segura entre quatro paredes, das quais só vemos a janela. A mata, se bem que mais próxima, continua a ser mantida à distância. Tudo que é potencialmente perigoso em relação à natureza fica controladamente longe. Neste anúncio, ao interlocutor também é destinado o lugar seguro, dentro dessas quatro paredes, certamente reforçadas e pintadas com os produtos da BASF.

Isso provoca sentidos muito diversos das imagens alemãs discutidas acima. Não se constroem ethé de coragem ou potência para esse interlocutor, mas de acomodação a uma vida calma, familiar. É iniciada a criação de um ethos de liderança que funcione como um guia protetor a indicar o caminho, já que são veiculadas crianças. Estas inspiram cuidado com os mais fracos, com os que estão em relação assimétrica de poder.

Essas imagens evocam scripts de afetividade, pois o leitor priva da intimidade dessas personagens. Surge também um ethos de pureza, dentro 
dessas famílias tão felizes, compostas por seres protegidos de possíveis agruras, tanto atmosféricas como de qualquer outro tipo. À BASF cabe o papel de guia a mostrar o que deve ser visto: 'Se a gente não mostrar, você nem percebe.' Criando para si ethé de humanidade, liderança e poder para moldar comunidades.

Nos dois países, os anúncios apresentam uma ordem até bem tradicional da Retórica, porém atualizada com a inserção das possibilidades que a moderna mídia oferece:

- um título que se move para pontos estratégicos do olhar e que juntamente com a foto compõem a função de captar, manter a atenção e funcionar como parte da argumentação, evocando scripts desejados e orientando para a conclusão;

- o uso das duas expressões - gráfica e textual - que funcionam de maneira complementar e não paralela, potencializando as possibilidades de interpretações desejadas que sem o uso das duas seria impossível;

- o modelo básico usado nos anúncios, tanto brasileiros como alemães, é o da 'classe argumentativa', que segundo Koch (1992:30) é "o uso de enunciados que podem igualmente servir de argumentos para uma mesma conclusão." É como se fosse uma espécie de lista, onde aparecem vários argumentos sobre o mesmo tema, a fim de respaldar e direcionar o leitor para a conclusão desejada pelo enunciador. O que é bem compreensível dentro da argumentação erística da qual a publicidade faz uso, isto é, louva o bom, o belo, o útil, o essencial, o agradável;

- esse processo ocorre com termos que já provocam a modalização desejada, como, por exemplo, expressões pretensamente 'científicas', termos comodificados que funcionam como índices lexicais de avaliação positiva;

- a composição visual do anúncio, também, funciona como uma argumentação modalizada, predispondo e conduzindo o interlocutor a criar sentidos desejados;

- uso de expressões fraseológicas, nos dois países, com o mesmo intuito, isto é, de evocar, com rapidez, os scripts desejados pelos produtores dos anúncios; 
- a existência de um início e uma finalização, feita em fórmulas fixas, de modo a se ancorar mais facilmente no espaço mental do consumidor;

Tudo isso contribuindo para a construção da identidade empresarial da BASF, composta de qualidades como seriedade, competência, inteligência, poder, essenciabilidade, fidedignidade, liderança, assim como de características próprias para a construção da identidade de seus leitores, de acordo com as possibilidades de identificação cognitiva, que são tidas como sendo próprias dos interlocutores de cada país.

As peças assemelham-se, também, em relação ao tema: "a contribuição imprescindível da BASF mantém-se imperceptível e por isso os anúncios têm a incumbência de mostrá-la".

As diferenças começam a surgir nos motivos e formas escolhidos para essa última tarefa. Essa é uma campanha publicitária internacional, a identidade para a BASF é definida como sendo semelhante para os dois países em que são apresentadas as campanhas. Porém as diferenças quanto à cultura e as condições sociais de cada país são levadas em consideração, para que a campanha seja a mais eficaz possível lá e cá.

O título do anúncio alemão é mais conciso e impactante, semelhante a um fraseologismo, como um provérbio, fácil de gravar pela sua própria concisão, ritmo e repetição e que se ancora no espaço mental do leitor como se fosse uma unidade lexical, mas com possibilidade de sentidos abertos: Unsichtibarer Beitrag. Sichtibarer Erfolg. (Invisível contribuição. Visível sucesso).

A contribuição da BASF, que não pode ser vista pelos leitores alemães, segundo o título, remete ao Erfolg/sucesso individual e ao trabalho/Leistung. Funciona como o reforço lingüístico ao ethos de coragem, audácia e potência da imagem. Fica ao encargo dos leitores perceberem que a BASF é responsável pelo 'seu' sucesso, por um processo de identificação, ainda que inconsciente. Mesmo porque o benefício, conseguido pelo sucesso de alguns, serão extensivos a todos, de acordo com a peroração: "So tragen wir zum Erfolg unserer Kunden bei. Und zu mehr Lebensqualitäten für alle.". Essa é a função do mito do Herói. O seu sucesso de sua empreitada é extensivo ao resto da comunidade e por isso esta se salva. 
Essa colaboração da BASF, sobre a qual se vai falar e que, também, não é vista claramente, no Brasil, remete ao cotidiano dos leitores ao seu dia-a-dia, não ao sucesso. O título é mais extenso, avisa que vai pegar o leitor pela mão e mostrar-Ihe o que ele é incapaz de ver por si próprio. Deixa implícita uma injustiça para com a BASF que faz tanto por ele: '... mas você nem percebe." Reforça-se, já no título o ethos de humanidade - uma relação de assimetria - que começou a ser criado a partir das imagens que incitam à proteção como: o uso crianças ou de figuras protetoras. A captação da afetividade começa já no título, com o cuidado de provocar uma intimidade que permite demonstrar sua intenção de guiar para a 'iluminação'.

Para os leitores, habituados a lerem os anúncios da BASF, na Alemanha ou no Brasil, não é preciso gastar muito tempo para identificá-los. Parecem estar de acordo com a noção de textos formuláicos proposta por Gülich (1997) e discutidos na parte teórica (p.71). Só é necessário preencher os lugares vagos com as novas imagens e as partes textuais adequadas a elas.

A composição visual e lingüística recorrente, à maneira de cada país, faz com que os leitores, automaticamente, acionem o que já 'sabem' sobre a situação e sobre a BASF, a partir de outros anúncios. Isso age como um repetitivo estímulo pavloviano.

Essa repetição de detalhes remete ao conceito de intertextualidade esboçado por Fix (2003), pois podemos agrupá-los de acordo com sua forma de composição visual e construção lingüística como sendo: 'este texto é um anúncio da BASF'. O leitor já aciona os scripts criados por outros anúncios anteriores, mesmo estes não estando presentes, já que o silenciamento também é uma forma atuação. É uma campanha feita por repetições. A campanha em si assemelha-se à figura retórica de repetição de informação: pleonasmo.

Neste contexto de repetição e intertextualidade deve ser lido o terceiro anúncio alemão. Ele dialoga com os anteriores, pois apresenta o mesmo esquema de composição visual e lingüística, porém o fato de conter uma personagem feminina, na situação que foi apresentada, além da argumentação lingüística, constrói outras significações. 
Do domínio masculino no campo dos esportes, parte-se para o mundo do domínio, tido como, feminino, pelos produtores, isto é, a natureza doméstica dos empreendimentos, assim como para o terreno da sedução erótica. Para isso contribuem, respectivamente, os fraseologismos e o visual. Desta vez, o leitor pode se identificar com o herói que continua embutido neste anúncio, por intermédio de uma intertextualidade que remete aos anteriores, ou com o papel feminino, feito Penélope, à espera da volta do herói. Depende do leitor ou leitora.

Outro índice de Intertextualidade, pode ser considerado a recorrência de alguns ethé como competência, poder, onipresença, seriedade, essencialidade em ambos os países, o que contribui para a criação da identidade da marca BASF junto ao espaço mental do consumidor.

Ambas as publicidades usam do paroxismo proposto por Morin (2002), quando este discute sobre o recorte matemático que se faz do mito. Essas repetições sistemáticas aparecem como os únicos componentes de relações muito mais complexas do que as mostradas nos anúncios. Trata-se de um típico produto da mídia homogeneizadora da qual nos fala Morin (1990). Após a redução dos possíveis sentidos dessa relação complexa, sobram, ainda, alguns elementos iconográficos com os quais o leitor é levado a se identificar. Essa identificação buscada seria apenas com os poucos e pobres elementos utilizados no anúncio. Identificação com estes e apenas com estes sentidos, que procuram ser controlados de maneira a ter conseqüências previsíveis para as conclusões dos leitores.

Nos anúncios alemães, temos esse Herói fragmentado em sua significação, esvaziado de sua função de explicar situações de dificuldades à comunidade à qual pertence, de conseguir essa iluminação a custo de sacrifício, o que seria revertido em prol do benefício da comunidade. É realçado apenas o seu aspecto de obstinação, solidão, independência, comportamento adrenérgico, e o trabalho extenuante representado pelos empreendimentos esportivos.

Essa solidão e obstinação no trabalho/atividade do Herói, claramente acentuada, só é facilitada pela onipresença da BASF que funciona como o mentor, o ser sapiente que o ensina a se mover no perigo e a tirar o máximo de proveito 
dele. É ela que the fornece tudo que é necessário (a poção mágica) para que vença em suas empreitadas arriscadas. Parece que, por intermédio do exercício da solidão, procura-se mostrar a independência e a força dos personagens representados. O que corrobora a imagem do herói que está sempre solitário em seus trabalhos.

$\mathrm{Na}$ publicidade brasileira temos hiperbolização desse aspecto, digamos, rotineiro, sem grandes arroubos aventureiros, apresentando, apenas, fatos da vida cotidiana, aconchegante que deve parte do script do que deveria ser uma família feliz, saudável, em um meio ambiente também tão simples e pacífico como ela própria.

Nessas narrativas, a estrutura familiar é apresentada com o mesmo paroxismo que a situação solitária dos personagens alemães. $O$ anúncio brasileiro procura construir um ethos de afetividade e humanidade a partir do uso da inscrição do leitor no anúncio: o 'seu' dia-a-dia, 'o seu mundo', assim como a nomeação fictícia (Souza, Soares) de famílias, da mesma forma que a presença da BASF no cotidiano procura representar um sentido de intimidade. $O$ que não ocorre nos anúncios alemães.

A peça publicitária não tem nada de audacioso, pelo contrário, coloca 0 leitor numa posição de passividade, restrito a um pequeno mundo, aparentemente, sem vontade própria de sair dessa situação de 'felicidade' infantil paradisíaca. Uma constante chamada ao mito de 'Brasil, país do futuro.' É a BASF, a Grande Mãe protetora, que mantém a paz da proteção familiar. Como o anúncio anterior, este também trabalha com o arquétipo da proteção de componentes domésticos.

Se for comparado com os anúncios alemães, parece haver receio de mostrar algo que provoque audácia, omite-se qualquer sinal de confronto, mesmo que seja um confronto com o meio ambiente, como ocorre nos anúncios alemães.

Daí a ênfase da BASF brasileira em propagar seus projetos de cuidado com a comunidade, demonstrando preocupação com o tecido social. Audácias onde 0 indivíduo solitário, parte para alcançar sonhos, definitivamente, não tem lugar nos anúncios brasileiros. Opta-se, então, por figuras que divulguem os temas de proteção, solidariedade e paz. Nada que provoque mudanças que não sejam as 
controladas por projetos comunitários, tão alardeados também por outras empresas, brasileiras ou multinacionais instaladas no Brasil, como Natura, CocaCola, Boticário e Mc Donald, que se apresentam com imagens maternais, com "seus filhos", comunidades e natureza, igualados, sendo cuidados e protegidos.

Em relação à situação de solidão dos alemães, nos anúncios brasileiros, ocorre o oposto. Não há personagens solitários. A solidão parece incomodar os leitores brasileiros, de acordo com os produtores, já que, os primeiros sempre são apresentados em situações gregárias. Isso reforça a conclusão de que, nos anúncios brasileiros, o espaço destinado aos leitores é o de fazer parte de grupos coesos.

Por isso a insistência em trazer para o anúncio brasileiro o discurso subliminar patriótico, que é um dos discursos institucionais que visa proporcionar a sensação de coesão entre seus cidadãos. Com isso, talvez tente amenizar o fato de se tratar de uma empresa estrangeira, assim como outras o fazem. Vide patrocínios da Coca-cola na época de jogos olímpicos ou de Copa do Mundo, quando ela patrocina equipes brasileiras e transmissões esportivas, apresentandose como 'a torcedora brasileira' de nossos times e atletas.

Esse discurso subliminar patriótico se torna extremamente efetivo, pois ocorre no espaço do inconsciente do indivíduo e de maneira autoritária conduz o processo de criação de sentidos pelo leitor, sem que esse se dê conta, e acarreta uma fusão, um embaralhamento da BASF com a pátria. A BASF faz o papel não do Mentor que fornece o amuleto esotérico ou a poção mágica para o sucesso e os grandes feitos, mas da Grande Mãe que mantém a paz e a segurança, no momento em que subvenciona projetos que deveriam ser feitos por um Estado que, aparentemente, se encontra ausente de suas funções mais básicas como educação e cuidado com o ambiente de seus cidadãos e com suas crianças.

Dessa forma, resta para os interlocutores brasileiros o lugar passivo, como de receptores dessas ações que partem de outros e não de si próprio na resolução de seus problemas.

O mundo do esporte, que nos anúncios alemães aparece como metáfora do mundo do trabalho, não tem espaço nos anúncios brasileiros. Aos brasileiros não 
cabe a força pela vontade / "Kraft duch Wille", assim como também não cabe o audácia com possíveis ganhos / "Wer wagt, gewinnt." Ao leitor brasileiro da publicidade brasileira resta o lugar de interlocução de um povo que espera que the expliquem qual é a solução para seus problemas.

A função das campanhas publicitárias é criar uma identidade tanto para as empresas como para seus interlocutores, e estimular para que haja possibilidades de identificação desses últimos com alguns dos elementos apresentados na narrativa publicitária. Uma das possibilidades de identificação é justamente o uso de elementos mitológicos. Entre as funções dos mitos (p.147), dentro das sociedades, assim como da publicidade, estão, justamente, seu caráter sociológico e pedagógico. O que se pode depreender dessa discussão feita acima, é que o lugar dos brasileiros e dos alemães, dentro dessas identidades criadas pelos anúncios veiculados, são bem diferentes.

Com imagens, fraseologismos, elaboração argumentativa que evocam imagens da natureza como dificuldade, ou perigo, a identidade dos alemães é explicada sociologicamente como sendo os que conseguem tudo por força de sua própria vontade. A figura do herói que tudo consegue por força e vontade justifica o comportamento, assim como ensina de que maneira se deve agir. Lemas como: 'querer é poder', 'quem arrisca consegue', parecem querer fundamentar os anúncios alemães da BASF.

Já na campanha brasileira, para a criação da identidade estimulam-se outras características bem diversas. Constroem-se imagens e fraseologismos que evocam a sensação de cuidado e proteção do outro, com cotidianidade paradisíaca, presente no dia-a-dia, dentro e fora da janela. Isso estupula aos interlocutores do anúncio brasileiro um lugar de ser pacífico, um interlocutor apático, à espera que se resolvam os problemas porque talvez não seja maduro o suficiente para fazê-lo. Mantém-se dentro do imaginário que se criou de que este é um país ainda jovem e por isso necessita de ser educado, cuidado, dirigido.

Os anúncios alemães seguem o modelo tradicional patriarcal de como deveria ser uma sociedade (na visão da BASF). Aos homens é destinado o lugar 
de heróis de grandes feitos e à mulher, o lugar da sedução, do erotismo, à disposição do falo e do prazer.

Os anúncios brasileiros também seguem o modelo patriarcal, porém mais voltado para a manutenção da ordem social, estabelecida por intermédio da presença de uma figura parental, da construção familiar, do cuidado com prole, da proteção à infância e ao meio ambiente.

Pelo que se deixa perceber pelos acordos existentes, entre os produtores dos anúncios e os seus leitores, que transparecem nos anúncios analisados, o enfoque da natureza também é muito diferente nos dois países.

No imaginário alemão, a natureza aparece em estado bruto, intacta, com sua grandiosidade e pureza original conservada, ainda com seu poder de submeter os homens a dificuldades mortais. E por isso a BASF é necessária, para ajudá-los a transformar-se em heróis em sua conquista, saindo da aventura mais fortes e valorizados. Não domando a natureza nem transformando-a, apenas enfrentando seus desafios.

No Brasil, a natureza aparece como domada, circunscrita a ser olhada da janela ou no máximo usada para um aprazível piquenique feito por crianças. Nada de desafiante ou assustador. Uma natureza que parece transformada em gramados, tendo matas bem pouco grandiosas para serem admiradas ao longe, ao fundo.

Em seu texto, não se fala de 'ventos e tempestades', pelo contrário, a notícia que se tem dessa natureza é que ela já foi submetida às ações humanas predatórias, encontrando-se em estado que necessita de ajuda, assim como necessitam de ajuda as comunidades que nela vivem. Por isso a vinculação da BASF com um discurso patriótico com a BASF, assumindo a tarefa de manter o que está intacto e colocar em ordem o que foi desarrumado. O Estado não seria totalmente competente para tal empreitada, daí a BASF colocar-se como possível coadjuvante. 


\section{Viagra/Pfizer}

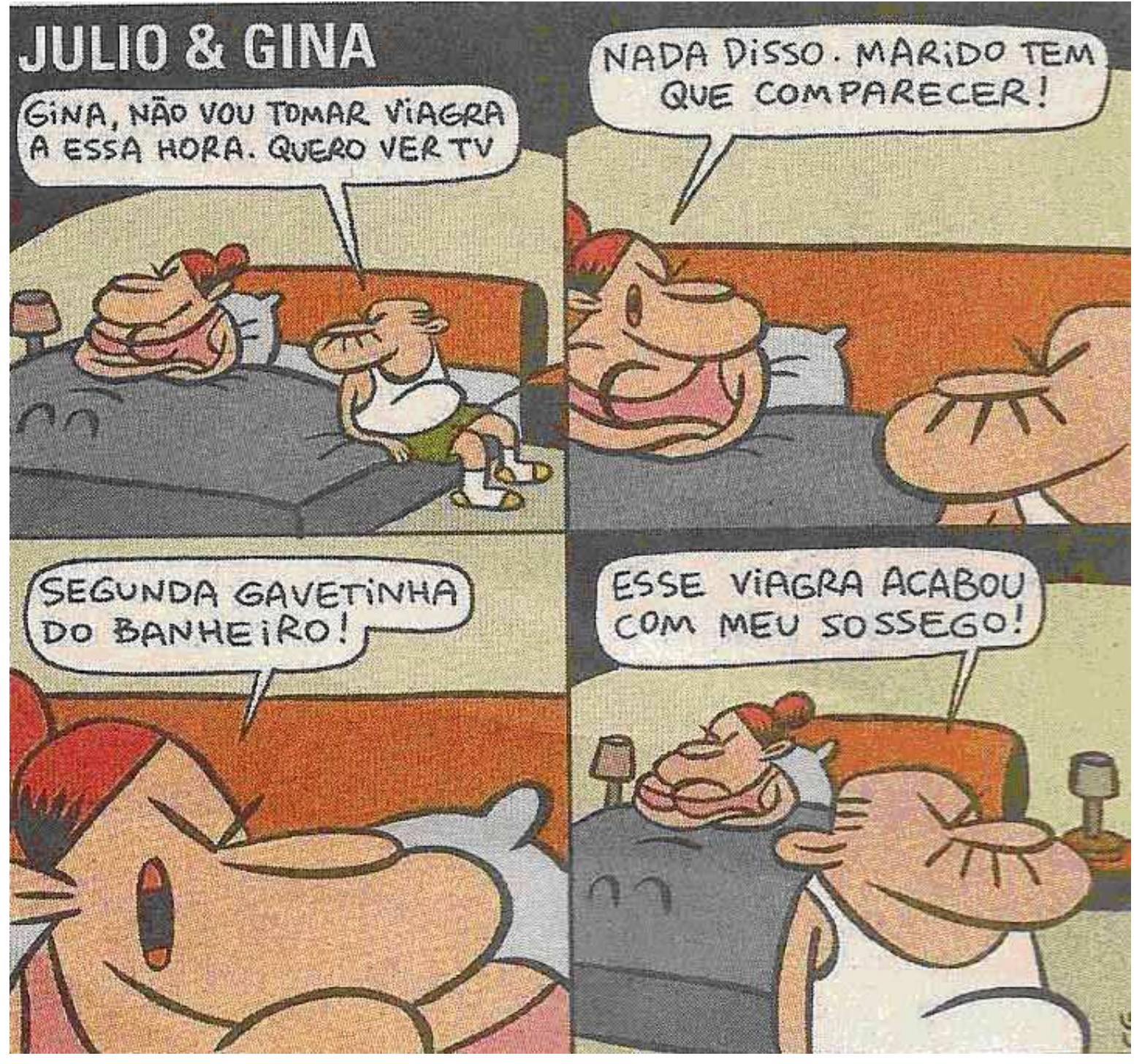

(GALHARDO, Folha de SP, 20, fev, 2006) 


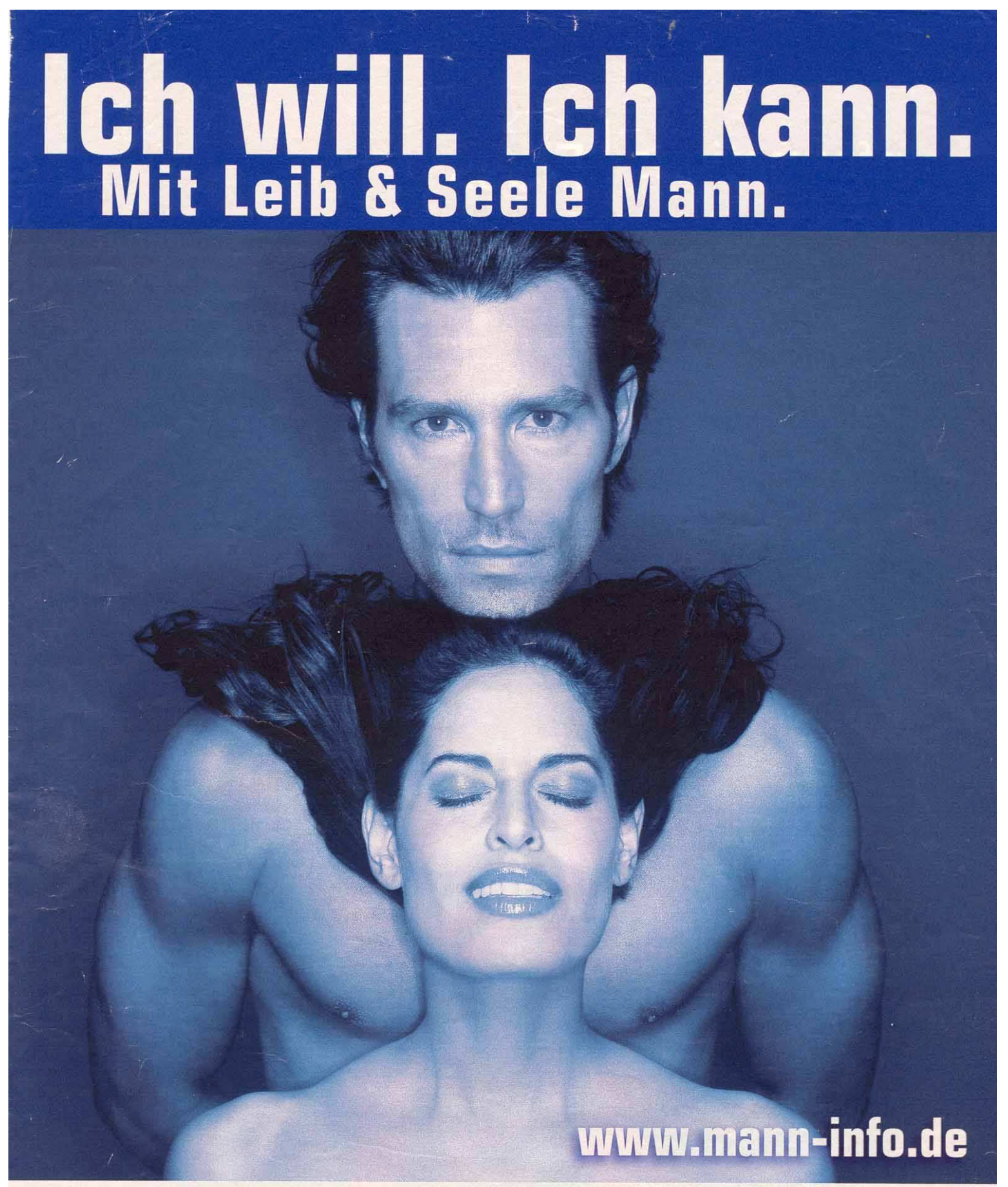

Und wenn Mann will, aher nicht kann?

Fragen Sie Ihren Arzt. Er kann Ihnen helfen.

Guter Sex tut gut. In jeder Beziehung. 
5.7. Anúncio veiculado pela revista 'Der Spiegel', em suas edições de 21/11/05, 1/08/05, 15/08/05, 05/09/05, 12/09/05,17/09/05.

Análise da composição visual do anúncio - O layout tem a seguinte composição gráfica: um retângulo vertical, no formato da página da revista. Este é dividido em dois retângulos horizontais, um na parte superior e outro na inferior, com um quadrado entre eles. O que ocupa a parte de cima é uma faixa azul marinho, estreita, com letras vazadas, grandes.

Estes elementos - tipologia seca, sem serifa nem ornatos, contraste do azul escuro da faixa com o branco das letras e tamanho dos tipos - produzem um efeito impactante imediato assim em quem se depara com o anúncio, fornecendo uma modalização acentuada do que vem escrito na caixa. O segundo retângulo encontra-se na base. Este é branco com parte do texto em letras pretas e outras em azul, no mesmo tom do retângulo superior e do logotipo da Pfizer, que ocupa o canto inferior direito e aparece em letras vazadas sobre um oval azul.

Comparado com o título, este texto vem menos modalizado. As letras, menores em azul e preto, provocam uma reação que tende mais para 'fria', do que para a impactante do título. A parte central do anúncio, um quadrado, é ocupada pela foto de um casal jovem, nu - pelo menos na parte mostrada no anúncio. $O$ homem, mais alto, está por trás, de olhos abertos e fitando o leitor, de maneira direta, penetrante e também de forma um pouco dura, provocativa. Como se exigisse algo ou uma resposta. Está com o queixo sobre a cabeça da mulher, cujos cabelos, jogados sobre os ombros dele, formam um triângulo, em conjunto com o rosto dela. Ela está de olhos fechados, com cara de prazer (de estar se sentindo bem e feliz).

Os dois personagens representados recebem uma tonalização mais forte, o que faz com que "saltem" em direção ao leitor. Dessa forma, tornam-se mais modalizados, parecendo mais próximos do leitor.

A escolha pela cor azul que reina no layout é feita, provavelmente, com a função de facilitar a associação com a cor da pílula Viagra, que, pelo menos no Brasil, já é conhecida pelos homens como "a azulzinha". 
Com relação às indicações feitas por vetores, temos os braços do personagem masculino. $O$ esquerdo indica para o texto maior, abaixo, e o direito indica para o endereço eletrônico e o logotipo. Os braços femininos, que não aparecem, também têm essa função, pois o leitor sabe que estão aí. As duas cabeças formam como uma seta a indicar o título.

Esses jogos de linhas, como de praxe, levam a outras construções de sentidos, não tão claras como essas indicações. Existem vários triângulos, dentro desse quadrado, nessa composição. Um triângulo maior, composto pelas figuras masculina e feminina, no qual o vértice superior é a cabeça do homem e a base é a lista formada pelos ombros da mulher. Este, por sua vez, é composto de outros triângulos: os braços e peito do homem formam os dois triângulos laterais que envolvem o rosto da mulher como que prendendo seu pescoço.

A figura da mulher é composta por dois triângulos, o primeiro, com o seu rosto e corpo seguindo a orientação do triângulo maior, com a base para baixo; o segundo encontra-se localizado bem no centro da foto. É composto pelos cabelos e pelo rosto da figura feminina. Trata-se de um triângulo invertido, cuja base está voltada para cima, enquanto todos os outros triângulos têm a base para baixo.

Gostaríamos de relembrar o que foi discutido na parte teórica com Key (1990) a respeito do uso de imagens que se ancoram na mente dos leitores de anúncios de maneira subliminar, principalmente quando essas imagens lidam com assuntos tabus, muitas vezes com temas arquetípicos. Elas não são normalmente percebidas pelo consciente, mas registradas pelo inconsciente.

Este jogo de triângulos são símbolos que remetem ao arquétipo do feminino e do masculino. O triângulo com o vértice para cima é tido como a representação do fogo, do impulso ascendente, do masculino, da potência viril do falus. É também símbolo do movimento ascendente que pleiteia uma unidade com o divino, com algo superior, como indica o sentido do vértice (CIRLOT, 1985).

Já o triângulo invertido, que tem a base para cima, vale como símbolo da água, do feminino, como repositório, como possibilidade da procriação. $O$ triangulo, diferentemente do círculo que tende a proporcionar a sensação de paz, e de segurança, leva a percepções psicológicas de tensão e de movimento. $\mathrm{Na}$ 
composição, foram usados os dois tipos de triângulos e isso ocasiona percepções de conflitos e ao mesmo tempo de complementaridade.

A foto é composta, basicamente, por figuras geométricas, angulosas, com retângulos - que, além dos já citados, também surgem no rosto do personagem masculino -, quadrado, triângulos, estes últimos reforçando a característica de virilidade masculina.

No personagem feminino, os lábios carnudos entreabertos, os olhos fechados, o rosto menos agressivo - por não ser anguloso, mas tender para o oval -, a sobrancelha mais arqueada, tudo isso contribui para uma construção de sentidos que induzem ao contraponto da dureza do resto do anúncio. Esses elementos indicam um comportamento de espera por parte do personagem feminino, de acordo com a forma como são colocados. A posição central da cabeça da mulher, juntamente com os cabelos levantados, formam o triângulo feminino. Se levarmos em consideração os cabelos nessa composição da imagem, podemos perceber a semelhança com a região pubiana feminina, a imagem chega a ser grosseira.

Todos os traços discutidos acima apontam para um script de relacionamento sexual, em que a figura masculina é apresentada como determinadora, a que faz, e a figura feminina como a que recebe. Percebe-se tal intencionalidade, inclusive, ao prestarmos atenção no formato do rosto do modelo masculino: duro, reto, longilíneo, com a barba por fazer, criando um círculo em sua parte inferior. Parte do queixo penetra no triângulo formado pelo conjunto dos cabelos com o rosto feminino.

Essas informações podem ser constatadas, colocando-se o anexo três sobre o anúncio. Percebe-se que esse anúncio é todo construído em cima de formas triangulares.

Esse contexto vai ter conseqüências na forma como o problema da disfunção erétil é abordado no anúncio.

Análise da composição lingüística - A determinação, a potência, a dureza que surgiram modalizadas pela cor, forma e tamanho das letras dentro do 
retângulo superior são reforçadas, agora, pela parte lingüística, por intermédio do enunciado que funciona como título:

"Ich will. Ich kann." / "Eu quero. Eu posso."

O enunciado seguinte, em letras menores, mas do mesmo tipo, é o título expandido. E já pode começar a ser considerado parte da enumeratio, pois os argumentos começam:

"Mit Leib \& Seele Mann" / "Com corpo e alma homem!".

www.mann-info.de - Abaixo da foto, no lado direito, lê-se o endereço da internet:

Abaixo, no lado esquerdo, com letras pretas em fundo branco, um bloco de enunciados:

"Und wenn Mann will, aber nicht kann?"/ "E quando o homem quer, mas não pode?"

"Fragen Sie Ihren Arzt. Er kann Ihnen helfen." / "Pergunte ao seu médico. Ele pode ajudá-lo."

Destacado, um pouco mais abaixo: "Guter Sex tut gut. In jeder Beziehung." / "Bom sexo faz bem. Em todas as relações".

No canto oposto, vê-se o logotipo da Pfizer.

Fraseologismo - "Ich will. Ich kann."/“Eu quero. Eu posso."

O primeiro enunciado surge na forma de um fraseologismo, organizado em forma de parataxe.

"Ich will und ich kann." e „Wenn (falls) ich will, kann ich”, remete o leitor ao dito popular: 'querer é poder' ('Wollen ist können'). Funciona como um clichê que aciona scripts de determinação, força de vontade, e tem atuação mais potente ainda quando é feito de forma individual, pois aí passa a depender única e exclusivamente da força do leitor.

"Eu quero. Eu posso." A estrutura da lógica patriarcal do 'poder pelo querer', sem levar em consideração os outros, é reforçada. É quase uma 'novilíngua', como dizia Orwell em seu livro '1984'. A impotência (= NÃO PODER) 
- o nome popular da disfunção erétil - é trocada por potência (= PODER). homem 'pode' e o olhar do personagem confirma isso. Querer é poder, portanto, se eu quero nada me impede.

Essa identidade que o anúncio busca construir para fazer parte de seu inventário perceptual é formada da triangulação entre a imagem, o enunciado e o referencial valorativo positivo ao qual remete o dito popular. Constrói-se com isso o ethos de potência, que se apóia no rendimento individual, com sua energia física e sua vontade, expressas por meio de figuras que demonstram virilidade, potência sexual.

Dessa forma, já se inicia a preservação de face do interlocutor que possa sofrer do problema para o qual o remédio parece ser a solução. $O$ fato de necessitar do remédio não deve colocar em questionamento a virilidade do possível usuário. $O$ anunciante tem cuidado ao trabalhar com um tema que é potencialmente ameaçador para a face dos leitores que podem se sentir agredidos, tanto pela apresentação do tema em uma revista à qual muitos têm acesso, como por ver seus problemas sendo tratados abertamente em uma revista e, também, para sua própria 'face' enquanto empresa que corre o risco de desagradar consumidores ao provocar uma dissonância cognitiva. $O$ tema comprova-se de difícil abordagem.

"Mit Leib \& Seele Mann" / "De corpo e alma homem!". - Esse enunciado reforça o anterior e se reforça por intermédio do recurso do ritmo e rima criada entre 'Mann' e 'kann'. O termo Seele/alma fica exatamente na linha formada pela cabeça dos dois personagens. Isso pode induzir à conclusão de que a alma tem uma importância maior que o corpo. E, também, pode levar à mensagem de que o querer tem a ver com o corpo, com a necessidade fisiológica de sexo. Já o poder, o conseguir, o ser capaz, dependeria da alma, da mente. Ich will mit Leib/ eu quero com corpo \& Ich kann mit Seele/ eu sou capaz com alma.

Percebe-se a função intermediadora e complementar da imagem para o texto, assim como do texto para a imagem. Não adianta ser homem apenas com a alma e sem o corpo. Os dois se completam. Daí a escolha da foto de um homem bem másculo, acima da mulher, mostrada aparentemente satisfeita. Esse homem 
pode ser o leitor. E a leitora poderia ter um homem completo como esse. Um homem integrado em corpo e alma. Não só um, nem apenas outro. Essa alma se completa quando em conjunto com um corpo, másculo, forte, vigoroso, que tudo quer e tudo pode.

Essa construção compõe um ethos de sensibilidade. Esse personagem, que se apresenta tão duramente, tão poderoso, por intermédio do dito: Ich will. Ich kann, tem alma e pode não ser tão poderoso assim. Começa a ser introduzida a vulnerabilidade do personagem, tendo-se o cuidado para não colocar sua masculinidade sob ameaça.

Aparece a colocação da razão de ser do anúncio, mas ainda de uma forma amenizada: a publicidade de um medicamento que trata do descompasso entre 0 desejo e a atividade sexual masculina, que começa a ser discutida abaixo, na enumeratio (fornecer detalhes): "und wenn Mann will, aber nicht kann?" $E$ na argumentatio: "Fragen Sie Ihren Arzt. Er kann Ihnen helfen." A peroratio (tomada de posição pessoal) surge no final: "Guter Sex tut gut. In jeder Beziehung." /"Bom sexo faz bem. Em qualquer relação."

Como a leitura dos ocidentais ocorre em forma de um ' $Z$ ' o próximo grupo a ser analisado é:

Und wenn Mann will, aber nicht kann'

A vulnerabilidade do personagem começa a ser demonstrada pela negação cuidadosa da afirmativa que compõe o título.

- Mann/man/kann - E quando homem/se quer, mas não pode.' Há um desvio da norma com o intuito de se formar um jogo entre o verbo 'kann', o substantivo 'Mann/homem' e o pronome apassivador 'se' (a gente) = 'man'.

,Mann' e ,man' não chegam a ser palavras homófonas nem homógrafas, mas nesse contexto a substituição de uma pela outra atinge o objetivo de provocar estranheza e chamar atenção. As frases não marcadas deveriam ser: „Und wenn man will, aber nicht kann?"/ "E quando se (a gente) quer, mas não pode?" ou então "Und wenn der/ein Mann will, aber nicht kann" / "e quando o (um) homem quer mas não pode'. Optou-se por colocar: 'E se homem quer mas não pode?' 
Uma proposição pode ser quantificada, entre muitas maneiras, pela inclusão do artigo determinado ou indeterminado (POLENZ, 1985). Essa quantificação explícita ou implícita fornece o aspecto de veracidade ou não à proposição. Nessa proposição, o que é apagado é justamente o aspecto de quantificação. Tem-se que recorrer ao contexto ou à problematização do enunciado para entendê-lo. A falta do artigo provoca uma generalização do termo, ao mesmo tempo em que o jogo entre 'man' e 'Mann' provoca uma indefinição de para quem pode ser dirigido o anúncio. Ambos os mecanismos levam a uma vagueza, tão característica na publicidade.

Neste caso, essa vagueza é bem vinda e tem pelo menos três objetivos: não constranger o leitor com a apresentação explícita de um problema que é tabu, sobre o qual, portanto, não se fala claramente; abranger a maior quantidade possível de indivíduos, já que a generalização gera essa inclusão e, ao mesmo tempo, não inclui diretamente ninguém em particular, Isso poderia ser um ataque à da empresa.

Operador de cópula - und - liga o enunciado seguinte ao que foi taxativamente afirmado acima, e introduz uma contraposição a ele. Poderia ser facilmente substituído por um 'mas', pois tem a função de redefinir o caminho da argumentação que se estava seguindo anteriormente no título. Porém o operador 'und' ameniza a mudança de rumo.

Operador - wenn - que insere uma condição, indicando a possibilidade de nem tudo estar em ordem com o "Ich kann"/ser capaz'. O desejo continua em ordem. $\mathrm{O}$ desejo masculino segue normal. Não há ameaça à masculinidade. $\mathrm{O}$ ethos de potência continua intacto. Essa possibilidade de algo não estar em ordem é colocada cuidadosamente como uma hipótese. Esse cuidado é em função da preservação de face do leitor que pode estar sofrendo justamente dessa disfunção erétil. Isso é feito em forma de uma pergunta retórica, que é uma forma de afirmar algo indiretamente (Polenz, 1985). Mas e se não for tão fácil esse comportamento viril, exigido pela sociedade?

Operador - aber - que desvia do argumento apresentado inicialmente e reorienta em direção diferente. Exclui o wollen/querer como suficiente para a 
realização de uma ação. No caso acima, a ereção, o sexo. Existe a hipótese apresentada conjuntamente pelo operador 'wenn' - condicional - e pelo 'aber' desviante -, de que o querer não seja suficiente. Por ser apresentado em forma de uma pergunta retórica, cria uma tensão, até certo ponto, angustiante. Mas ela é logo dissipada pelo enunciado seguinte. O que dá uma ênfase especial ao fato de surgir do nada a figura de um médico. Pois até agora não tinha sido tocado claramente em nenhuma doença ou problema.

\section{'Fragen Sie Ihren Arzt.'}

Em nenhum momento, ao longo do anúncio, fala-se abertamente sobre qual seria o problema: disfunção erétil. A argumentação é montada em torno de um problema sobre o qual não se fala. É um tabu falar sobre problema de ereção peniana. Seja qual for o problema que possa estar impedindo a realização do 'wollen/querer', eis que surge a solução. Ela aparece como um enunciado na ordem imperativa, ocupando o espaço discursivo autoritariamente, conduzindo à conclusão de que o assunto sobre o qual não fala claramente é um problema médico. O médico é o profissional, o especialista adequado dentro de uma sociedade de especialistas poderosos. Surge o ethos de competência por parte da Pfizer, que se faz representada. E logo no enunciado seguinte, é adicionado o ethos de humanidade, pois não se fala, aí, em cooperar, mas em ajudar/helfen.

\section{"Er kann Ihnen helfen".}

Os ethé de competência, humanidade, fidedignidade e seriedade fazem parte da figura do médico e indicam que o indivíduo não está só, que existem profissionais sensíveis, dispostos e com competência para ajudar. É algo estritamente profissional. O ethos de humanidade, ao sugerir que o usuário do remédio necessita de ajuda, é amenizado pelos outros ethé que se colocam de maneira mais clara, como o de potência e competência.

O enunciado "Ich will. Ich kann." deixa pouca margem para que seja criado um ethos de humanidade para o leitor. Este pende mais para a criação do ethos de seriedade, obstinação e inflexibilidade, já que há uma rigidez corporal, uma face séria, um auto-controle que depende apenas da vontade do indivíduo, mesmo 
que isso posteriormente seja colocado em xeque. A apresentação dessa característica preserva a face do interlocutor em relação ao problema que será apresentado posteriormente.

O verbo 'können/ser capaz', que faz parte do script de "Kraft durch Wille", utilizado no início do anúncio em relação ao personagem, passa agora a ser do domínio médico, o domínio da competência científica. O eixo desloca-se do indivíduo que é capaz quando quer, para o médico. Und Wenn Mann nicht kann, kann der Arzt". "Se 'homem' não pode, pode o médico." Ele é capaz. É um problema da ciência, de um especialista. Mas em nada abala o ethos de potência criado para o personagem por intermédio da imagem e do primeiro enunciado .

'Guter Sex tut gut. In jeder Beziehung.'

Fraseologismo - In jeder Beziehung/, em todo sentido ou em qualquer forma de relacionamento que possa haver.

Subentendido - o fraseologismo acima provoca uma ambigüidade. Esse enunciado final provoca possibilidades de várias leituras do anúncio. E a possibilidade de criação de sentidos aumenta se a foto for levada em consideração. Pela posição do cabelo da mulher, na foto, ela tem que estar deitada. Não tem como o cabelo de uma mulher ficar nessa posição se ela estiver em pé. O cabelo, ou parte dele, pelo menos, cairia. Se ela estiver deitada, o homem está, portanto, deitado por baixo dela.

O que pode levar o leitor a se perguntar sobre o que quer dizer 'In jeder Beziehung/em qualquer relação.' Sexo bom, faz bem; sexo bem feito em todas/em quaisquer relações e posições; além de não só com a esposa; não só por amor; não só em posições tidas como tradicionais entre homens e mulheres; não só entre homens e mulheres; já que uma relação com coito anal, o que a foto sugere, exige uma resistência peniana maior etc. Pode-se afirmar que a foto, juntamente com esse fraseologismo evoca os mais diversos scripts, muitos deles pouco conscientemente percebidos e, portanto, mais potentes.

Subentendido - www.mann-info.de - É interessante perceber que esse endereço de Internet vem do lado direito, funciona como a última coisa a ser dita 
dentro da estrutura em ' $Z$ ' da leitura ocidental. Reforça o ethos de humanidade, pois esse enunciado "mann-info" traz o subentendido: "você não está só, se tiver curiosidade (necessidade), procure-nos". Sem ameaçar a face do leitor, ele está aí para deixar no leitor a impressão de satisfação da curiosidade, do livre arbítrio.

É uma assinatura da Pfizer, juntamente com o logotipo. É a terceira retomada do termo 'Mann', usado no início. Assim como é retomado por intermédio do termo "info", o enunciado "Fragen Sie Ihren Arzt." Isso cria uma cadeia de enunciados diretivos para os leitores procurarem informação/ajuda, sem que se toque diretamente no problema. Esse enunciado parece remeter ao do segundo anúncio da Pfizer brasileira analisado neste trabalho: 'E se precisar, conte com a gente'.

\section{Inventário Perceptual Mitológico}

O lay-out do anúncio aponta para a construção de um ethos de potência para o personagem masculino, explora elementos de virilidade por intermédio de formas geométricas que indicam angulosidade e dureza. Pode-se perceber nessa construção do rosto do personagem, os mesmos elementos levantados por Marny (1970, p.123), para a construção dos personagens heróicos das histórias em quadrinhos, "rosto anguloso, pescoço grosso, olhar firme, corpo musculoso".

Ao mesmo tempo, constrói-se um ethos de passividade para o elemento feminino. Podem ser identificados elementos de Perséfone - já discutidos no subcapítulo 'Mitos', assim como no terceiro anúncio da BASF alemã: elemento feminino passivo, em compasso de espera, disponível ao masculino. Tal personagem também tem como característica ser incapaz de participar, plenamente, da vida adulta. Isto é, mantém características que fazem com que ela não se aperceba nem dos perigos a que se submete, nem das necessidades dos que a rodeiam.

Essa ausência de um personagem feminino atuante faz com que 0 personagem masculino do anúncio aparente estar ainda mais solitário. A presença, apenas icônica, da mulher, de olhos fechados, realça a solidão da tarefa 
do herói. $O$ anúncio é voltado para ele, como se dissesse que esse é um problema unicamente do homem.

\section{Conclusão Parcial}

Esse foi o único anúncio publicado pela Pfizer durante todo o ano de 2005 e que continuou a ser veiculado em 2006, na revista 'Der SPIEGEL', o que parece demonstrar que foi um anúncio que surtiu o efeito desejado pela empresa, senão teria sua circulação suspensa.

A estratégia argumentativa visual e lingüística do anúncio alemão dá um grande realce à criação de um ethos de potência, de energia física individual que deve ser acionada para resolução de problemas. O fraseologismo usado no início da peça publicitária evoca o script 'Querer é poder'. - "Kraft durch Willens" (o poder pelo querer). Script bem conhecido dos leitores alemães que têm em seu imaginário esse componente de Leistung/rendimento pelo esforço físico, que já foi tão claramente detectado nos anúncios alemães da BASF. O mundo do 'domínio masculino' (HOLLY, 2006), seja nos esportes solitários de alto rendimento seja nas vivências em relacionamentos sexuais, se faz culturalmente presente por intermédio da fórmula fraseológica "querer é poder".

A Pfizer opta, na Alemanha, por colocar o problema da disfunção peniana apenas nas mãos do elemento masculino. $O$ uso de elementos arquetípicos, mencionados na análise, procura levar o leitor à construção de uma compreensão textual que remete a assuntos sexuais e faz com que scripts, relacionados a esse campo, sejam acionados, ao mesmo tempo em que a argumentação lingüística procura conduzir para a conclusão de que essa é uma questão individual. Cada um pode ou deve resolver com sua força de vontade. É algo que diz respeito ao indivíduo Neste caso, o homem.

O personagem masculino da narrativa tem um olhar direto para o público, é mais participativo, chama o leitor para dentro do anúncio e o obriga a uma leitura centrípeta, trazendo-o para o que vai se revelando como um problema. Já o elemento feminino faz-se presente de maneira icônica. Apresenta-se como 
passivo. Seus olhos fechados tanto podem criar sentidos de que aparentemente está satisfeita com a performance desse indivíduo decidido, pois seu rosto aparenta isso, quanto podem ser uma forma de dizer que isso não é problema seu, é dele. Ela mantém-se alheia ao seu pesar.

O script acionado por esses elementos investe em um sexo em que a relação amorosa, o companheirismo não teria peso na resolução do problema. Investe-se mais na performance masculina, no rendimento/Leistung que o herói deve apresentar.

Se formos comparar este anúncio ao anúncio da BASF alemã, veremos a coincidência do realce do individualismo, do ser solitário que tem que lidar com um problema a ser vencido, que só diz respeito a ele próprio, seja no campo da performance esportiva seja campo da sexualidade.

Nos anúncios da BASF, temos a exaltação da figura do herói, do princípio masculino ativo, que deve atingir o sucesso e para isso conta com o poder do mentor esotérico - a BASF - que lhe dá a chave para tanto. Igualmente, o nosso herói dos anúncios da Pfizer também conta com o poder da Pfizer, que se faz presente na figura do profissional competente, o médico, o indivíduo capaz de fornecer a ele a chave da realização sexual, no caso o comprimido Viagra.

A junção da foto com o jogo de palavras do enunciado 'Guter Sex tut gut. In jeder Beziehung.' leva o leitor a pensar em diferentes formas possíveis de exercício da sexualidade, que, mesmo não sendo discutidas abertamente, levam à construção de um ethos de solidariedade com a apresentação e respeito aos pontos de vista diferentes do tradicionalmente esperado.

Fica claro, porém, que existe um tabu quanto ao tema apresentado. Em nenhum momento se fala sobre disfunção erétil ou sobre o nome do medicamento que se anuncia. $O$ anunciante percebe o tabu e o respeita, preservando a face de um possível usuário e a sua própria face, ao não tocar claramente num assunto tão delicado. Há uma dança de preservação de faces, um vai-e-vem entre querer e poder, entre desejo e ação. O assunto vai sendo colocado aos poucos, não sem antes fortalecer o ethos de virilidade dos leitores e dos possíveis afetados com os dois primeiros enunciados e a foto. Os enunciados finais é que vão, finalmente, 
orientar para o tipo problema e a ajuda. Mesmo assim, o primeiro vem numa frase condicional, isto é, livra a face do leitor, pois não o acusa de impotência. $O$ segundo já sugere que existe cura, pois a ciência, na figura do médico, já cuidou disso e fornece ajuda. O problema, "se é que existe", com esse enunciado passa das mãos do leitor para a ciência.

Os sentidos do anúncio vão sendo construídos a partir da junção da foto e do texto, extremamente cuidadosos na apresentação do produto anunciado, de forma que o leitor é persuadido a criar subentendidos que a necessidade de preservação de faces não permite que sejam expressos claramente.

O consumidor se apresenta por intermédio da construção dessa figura viril, decidida, independente, apolínea e forte, o suficiente a ponto de transformar qualquer desejo seu em realidade. Porém, caso isso não seja possível, ele pode contar com a Pfizer, juntamente com o médico responsável, o que é uma falácia, já que o medicamento é vendido livremente, sem necessidade de receita médica.

Deseja-se, com isso, transmitir uma aprovação 'abalizada' por parte de um profissional qualificado, a exemplo, entre outros, dos cremes dentais e de alguns alimentos que trazem as inscrições "aprovado pela Associação Brasileira de Odontologia", "aprovado pela "Associação Brasileira de Cardiologia" etc.

Há a clara necessidade de colocar a sexualidade "ideal", para a qual o interlocutor do anúncio, "talvez" possa encontrar-se incapacitado, como um discurso subliminar, de forma a não ofender os possíveis consumidores do medicamento e do anúncio. A sugestão de que o sexo torne-se, novamente, possível e prazeroso, apenas por meio de um auxílio externo deve ser cuidadosamente colocada. Seja esse sexo de que tipo for: "Guter Sex tut gut. In jeder Beziehung." 
Paixão segundo Nando Reis: "Faz muito tempo, mas eu me lembro, você implicava comigo. Mas hoje eu vejo que tanto tempo me deixou muito mais calmo $\mathrm{O}$ meu comportamento egoísta, o seu temperamento difícil. Você me achava meio esquisito e eu te achava tão chata. Mas tudo que acontece na vida tem um momento e um destino. Viver é uma arte, é um ofício.' Só que precisa cuidado. Pra perceber que olhar só pra dentro é o maior desperdício. O teu amor podel estar do seu lado. O amor é o calor que aquece a alma. O amor tem sabor pra quem bebe a sua água. Eul hoje mesmo quase não lembro que já estive sozinho. Que um dia eu seria seu marido, seu príncipel encantado. Ter filhos, nosso apartamento, fim de semana no sítio. Ir ao cinema todo domingo só com você do meu lado. O amor é o calor que aquece a alma." Para Nando Reis, paixão significa estar do seu lado. Para à' Pfizer, paixão é o que faz a gente pesquisar as curas para os males que afetam a qualidade de vida dos homens e das mulheres. E a gente faz isso todos os dias. Com paixão. C. 


\subsection{1. anúncio - VEJA 26/10/2005}

\section{Análise da composição visual do anúncio}

Esse anúncio é uma peça da campanha que foi lançada pela empresa Pfizer, no Brasil, durante o segundo semestre de 2005. A estratégia argumentativa do anúncio é o uso de um texto sobre o amor, escrito por pessoas famosas. $O$ texto publicado na revista VEJA é a letra de uma música do cantor e compositor Nando Reis. Outros anúncios foram publicados na revista ISTO É. Um é do poeta gaúcho Mário Quintana e o outro, da apresentadora e escritora Fernanda Young. Seguem, absolutamente, o mesmo esquema, tanto visual como lingüístico.

O anúncio é um jogo em branco e preto. Como pano de fundo do anúncio, aparece a figura de um casal envolto por uma bruma, lembrando um céu ao amanhecer ou ao anoitecer. Não se pode definir o horário. Tanto o jogo do branco e preto, da luminosidade, da indefinição por intermédio da bruma que envolve o anúncio, quanto o horário, são modalizações espaço/temporais, pois o casal, imerso nesse jogo, assume uma forma meio etérea, fora do tempo.

No anúncio podem ser identificadas algumas formas básicas. O casal abraçado, no lado esquerdo, forma um triângulo, com o vértice voltado para cima. Este triângulo está subdividido em outros, com o mais acentuado - formado pelo braço esquerdo da mulher, dobrado em forma de $\mathrm{V}$ - criando o triângulo feminino, com a base para cima (o ícone arquetípico da região genital feminina). Junto a esse, há os triângulos masculinos. Um, formado pela camisa aberta do personagem masculino e o outro, pelo seu braço direito, em conjunto com sua perna.

Tal organização das formas triangulares cria um certo antagonismo, uma tensão, que é aliviada pela posição do casal que se encontra unido, harmonicamente, como que se estivessem se protegendo mutuamente. Um outro contraponto às arestas dos triângulos é a existência das faces felizes de quem, em conjunto, resolveu problemas. Nesta sintaxe visual, esta imagem foi composta de forma a ser lida como um fraseologismo: "a união faz a força", ou como outros 
fraseologismos que evocam o mesmo tipo de script, que lembra carinho, ajuda, respeito etc., e que, ao mesmo tempo, traz um componente de sexualidade.

Um detalhe interessante a ser discutido é a forma como se encontra posicionado o casal. Ele está numa posição bem relaxada, sentado, com as pernas abertas. Tem a perna direita dobrada e sobre ela apóia a mão direita. Por encontrar-se em primeiro plano, isto é, no ângulo mais próximo do leitor, esta mão parece estar projetada em direção a este, e é praticamente a primeira coisa que se vê no anúncio, depois da iconografia do texto, ganhando acentuação e por isso funcionando como modalizada. Parece que foi, propositalmente, aumentada, a fim de chamar a atenção do leitor. Ela trabalha como um vetor a aponte-lo e a chamálo para dentro do anúncio. Tanto o homem quanto a mulher estão inclinados um na direção do outro, formando um triângulo perfeito.

Se, num primeiro momento, a inclinação pode indicar um estado de insegurança ou tensão, esta sensação se desfaz quando vemos que eles se apóiam um no outro, e dessa forma criam uma idéia de equilíbrio que se mantém enquanto estiverem unidos. $O$ homem se encontra em primeiro plano em relação à mulher, além de estar à esquerda. Isso provoca uma modalização de sua figura e se olharmos com mais cuidado veremos que a mulher apóia o homem por trás, como que cuidando dele. Começam a ser construídos os sentidos do texto, que são a união faz a força de um casal, todos deve ser solidários, sensíveis, cuidar uns dos outros, e o futuro, o tempo, melhora tudo.

Essa sensação de proteção, de calidez, aumenta com o círculo que se sobrepõe a eles, à altura de suas cabeças. Um dos poucos elementos matizados no anúncio é esse círculo em azul. Tal artifício remeteria o leitor ao medicamento Viagra, que, no Brasil, é conhecido popularmente como a "pílula azul". Isso é feito com muito cuidado, lembrando que deve haver a preservação de face dos leitores do anúncio que podem se sentir agredidos, por se verem expostos em um anúncio que fale sobre disfunção peniana.

Como se pode perceber, os personagens são colocados do lado esquerdo do anúncio. Isso de acordo com o modo ocidental de ver, indica que este é um fato já conhecido. No lado direito, surge o novo, a solução: o logotipo e o slogan 
da Pfizer. Para fortalecer essa direção de leitura, temos a luminosidade, que funciona como um vetor, e indica o caminho, o sentido do olhar do leitor. Essa luminosidade surge do céu, de um tempo/espaço não muito definido, funciona e se dirige para o plano terreno, para o real, o concreto, num crescendo, onde se encontram o logotipo e o slogan, o real, a Pfizer que produz o medicamento anunciado. Toda a escuridão - ou dúvida - do início do anúncio desaparece nesse final da argumentação visual.

Não é fácil identificar esse anúncio - assim como outros anúncios de outras empresas, que também foram analisados - como sendo publicidade de medicamentos que agem sobre a disfunção erétil peniana, pois os nomes dos remédios não aparecem.

Ao procurar por elementos do inventário perceptual mitológico que compõe esse anúncio, com certeza não serão encontrados elementos masculinos heróicos ou de virilidade, que resolvem tudo sozinhos, sem a ajuda de companheiras ou companheiros. Pelo contrário, temos um elemento masculino sendo cuidado pelo elemento feminino, amparado, protegido, quase que maternalmente. Encontramse, numa análise da sintaxe visual, elementos do arquétipo de uma Grande Mãe, que não condiciona seu amor a rendimentos, a performances de alto nível, mas é compreensíva, apoiadora e procura manter em pé seu nicho familiar. Resta saber se o elemento lingüístico corrobora essas idéias.

\section{Texto}

Linha 1: Paixão segundo Nando Reis: "Faz muito tempo, mas eu me lembro, você implicava comigo. Mas hoje eu

Linha 2: vejo que tanto tempo me deixou mais calmo. O meu comportamento egoísta, o seu temperamento

Linha 3: difícil. Você me achava meio esquisito e eu te achava tão chata. Mas tudo que acontece na vida tem um

Linha 4: momento e um destino. Viver é uma arte, é um ofício. Só que precisa de cuidado. Pra perceber que olhar só pra

Linha 5: dentro é o maior desperdício. O teu amor pode estar do seu lado. O amor é o calor que aquece a alma. 
Linha 6: O amor tem sabor pra quem bebe a sua água. Eu hoje mesmo quase não lembro que já estive sozinho.

Linha 7: Que um dia eu seria seu marido, seu príncipe encantado. Ter filhos, nosso apartamento, fim de semana

Linha 8: no sítio. Ir ao cinema todo domingo só com você do meu lado. O amor é o calor que aquece a alma."

Linha 9: Para Nando Reis, paixão significa estar do seu lado. Para a Pfizer, paixão é o que faz a gente pesquisar as curas para os

Linha 10:males que afetam a qualidade de vida dos homens e das mulheres. E a gente faz isso todos os dias. Com paixão.

Slogan no lado direito do rodapé da página:

"Muito prazer nós somos a Pfizer."

E logotipo.

\section{Análise da composição lingüística}

Inscrição do sujeito no anúncio

No início do texto, temos um locutor afirmando que o texto que se segue é de Nando Reis. Surge aí a primeira ambigüidade: se o locutor é a voz que foi delegada pela Pfizer a falar em seu nome (que chamaremos de L1) isto é, a agência ou a própria Pfizer (Lo) que assume o discurso. Logo em seguida, surge um outro locutor o L2, que vem a ser a voz do autor do texto sobre paixão, Nando Reis, sobre o qual o anúncio se apóia para criar seus sentidos. Nando Reis assume o discurso em primeira pessoa e se dirige a um 'tu', considerado o interlocutor de $\mathrm{L} 2=12$, a mulher da sua vida, com quem está junto até hoje, depois de um começo difícil:

O L2 inscreve-se nos dêiticos: L Linha 1 - 'eu, me, comigo', eu vejo;

Linha 2 - me deixou, meu comportamento;

Linha 3 - me achava, eu

Retoma na

Linha 6 - eu

Linha 7 - eu, 'nosso'

Linha 8 - meu lado. 


$\begin{array}{ll}\text { O I2 aparece na Linha } 1-\quad & \text { você implicava } \\ & \text { Linha } 2 \text { - seu temperamento; } \\ & \text { Linha } 3 \text { - você (me) achava, (eu) te } \\ & \text { achava; } \\ \text { Reaparece na Linha } 7- & \text { seu marido, seu príncipe, 'nosso' } \\ & \text { apartamento } \\ & \text { Linha } 8 \text { - você do (meu) lado }\end{array}$

A partir da terceira linha: "Mas tudo que acontece na vida..." até a sexta linha: "O amor tem sabor pra quem bebe a sua água.", o discurso passa a não ter um locutor explícito Assume um tom impessoal. $O$ autor passa a falar sobre a arte de viver, sobre o amor. O termo paixão, modalizado por estar logo no princípio do anúncio, não aparece uma vez sequer no texto. É uma construção de sentido imposta por $L 1$, apresentada ao leitor como sendo o referente sobre o qual tratará L2, o que na verdade não acontece.

A partir da sexta linha, volta o discurso de L2 em primeira pessoa. 'Eu hoje...' Desta linha até a oitava, refere-se ao que L2 e I2 construíram juntos nesse espaço de tempo, que parece ser longo devido às formas acionadas para designar essa referência: "faz muito tempo, hoje, tanto tempo. Surge o dêitico "nossos" filhos, reforçando o tempo em que estão juntos. E volta a frisar: 'o 'amor' é o calor que aquece a alma.

$\mathrm{Na}$ nona linha, o locutor que iniciou o texto (L1), retoma a fala, redefine e redireciona o texto de Nando Reis para o leitor, a fim de incluí-lo no texto e no anúncio. Para isso, usa o mesmo recurso que usou no início: "Alertamos" o leitor que para Nando Reis, a paixão é...", "Alertamos o leitor que para Nando Reis paixão significa estar ao 'seu' lado". O leitor, claramente, é chamado para dentro dos sentidos criados pelo texto de Nando Reis, através de sua inserção nesse 'seu'. Isso deve ser entendido como o L1 falando com o leitor I1.

Nota-se que no redirecionamento do texto o locutor (L1) não respeita 0 texto do autor. O L2 fala em amor, não em paixão. 
O L1 assume e fala sobre o que é paixão para a Pfizer. "Para a Pfizer (para ela), paixão é o que faz ..." Nesse ponto surge um "deslize" no qual a Pfizer assume o discurso em primeira voz com o uso do dêitico 'a gente', pois a agência com certeza não pesquisa a cura de males. A partir da linha 10 "E a gente faz isso todos os dias. Com paixão. Muito prazer, nós somos a Pfizer." O posicionamento de Lo como sujeito do discurso fica mais claro. Lo/Pfizer/a gente pesquisa todos os dias a cura de males que afetam a qualidade de vida. O logotipo passa a corroborar a unificação de Lo e L1.

Fica claro que há uma justaposição de vozes entre L1, a agência ou indivíduos estipulados pela Pfizer a falar em nome dela, Lo, a Pfizer, que se faz presente, explicitamente, no final, e L2, que tem a sua fala tomada e redirecionada para sentidos desejados de L1/Lo, da mesma forma, que há uma justaposição dos alocutários, I2, 11.

Esse excesso de vozes justapostas no texto provoca uma indefinição, uma vagueza. Essa pluralidade de vozes em nenhum momento pode ser considerada um erro. Pelo contrário, é intencional e fruto de uma estratégia de ocupar todo o percurso discursivo de maneira autoritária. Às várias vozes emaranhadas no anúncio provocam o efeito polifônico e buscam induzir o leitor à construção de sentidos desejados pelo enunciador, de forma persuasiva. O leitor vai se identificando com essas situações construídas ao longo do texto e assumindo que faz parte desse discurso através de um 'tu' dirigido a ele. Esse processo fica claro no final, quando o anunciante e a Pfizer afirmam que Nando Reis está escrevendo para o leitor: 'paixão significa estar ao seu lado'. O uso de 'seu' por L1 faz com que o leitor, seja definitivamente trazido para dentro do anúncio como um interlocutor real, inscrito, agora, em um dêitico, que embora dúbio, estimula essa criação de sentido. $\mathrm{O}$ uso do pronome 'dela' teria deixado claro o referente. Esse referente "seu" é a contraparte lingüística da mão modalizada da figura masculina, para chamar o leitor para dentro da foto. Aliás, os dois elementos, o lingüístico e o visual, encontram-se no mesmo lado e bem próximos.

A névoa visual, a partir da qual é composto o anúncio, evidencia-se também no jogo lingüístico, no qual o leitor sente-se sem um lugar definido para assumir 
sua posição interpretativa. O texto é um vai-e-vem entre o 'eu' ocupado por Nando Reis, e o 'tu', sua mulher, seu aparente interlocutor e o 'eu' impingido ao leitor. A este não resta senão participar do jogo, assumindo os vários lugares destinados aos alocutários.

Índice de autoridade / Intertextualidade manifesta - 'Paixão segundo Nando Reis:' Por demonstrar, claramente, a origem do texto aí inserido, essa intertextualidade manifesta constrói um ethos de autoridade, de seriedade. O texto tem um autor real, responsável, é conhecido por todos.

"Faz muito tempo, mas eu me lembro, você implicava comigo. Mas hoje eu vejo que tanto tempo me deixou mais calmo."

Fraseologismo - "Faz muito tempo,..." - funciona como uma espécie de aviso de que se vai falar sobre algo que interessa ao leito/ouvinte ("era uma vez..."), porém também age como um convite a um ouvinte não participativo, pois é algo que já aconteceu. Está implícito que o consumidor deve-se limitar a ouvir/ler.

Operador argumentativo - mas - mudança de orientação da conclusão $=$ eu me lembro, embora tenha passado o tempo. Isso constrói um ethos de sensibilidade, seriedade e persistência, pois mostra um locutor marcado por acontecimentos dentro do relacionamento afetivo, ao mesmo tempo em que dá uma dimensão histórica ao relacionamento. Não é algo de hoje, algo novo, inconseqüente. Nem foi algo fácil de ser mantido. "o começo é sempre difícil/Aller Anfang ist schwer."

Operador argumentativo - mas - Novamente mudança de direção. O que 'há tanto tempo' me irritava, não irrita mais = o tempo me deixou mais calmo.

Índice de autoridade - pelo uso de enunciados que demonstram conhecimento do senso comum de que o tempo "muda as pessoas, acalma, cura males", constrói um ethos de tolerância e inteligência, já que tem a capacidade de aprender com o tempo. Mantém o ethos de sensibilidade. Cria uma empatia com o leitor que, além de compartilhar desse senso comum, compartilha a intimidade do autor, construindo um ethos de intimidade. 
Começa a ser construído um certo fatalismo, a partir do uso do termo 'tempo', já mencionado duas vezes, que implica um destino que deve ser aceito.

Índice de pressuposição e modalização - muito mais - o 'mais' já funciona como índice de pressuposição. "Antes eu não era calmo". 'Muito' modaliza no sentido de acentuar o quanto o locutor não era calmo e o quanto se tornou. Continua a acentuação do ethos de sensibilidade.

'O meu comportamento egoísta, o seu temperamento difícil. Você me achava meio esquisito e eu te achava tão chata'.

Índice lexical de avaliação - Definição do caráter dos dois por adjetivação:

Ele = egoísta, esquisito $\times$ Ela $=$ difícil, chata.

Acentua a dificuldade dos primeiros tempos do casamento, pela enumeração das características consideradas negativas para um relacionamento. Aproxima-se do clichê: 'ninguém é perfeito'. O leitor deve facilmente se identificar com esse jogo de acusações entre parceiros, muito comum num período de ajustamento entre casais. "Que só o tempo cura." Funciona como a porta de entrada para que o leitor seja atraído a participar da construção do jogo de vivências especificados pelo anunciante e a se identificar com ela, embora sua participação seja passiva, como ouvinte de uma história. Constrói um ethos de virtude, pois é honesto ao fazer confissões, reconhecer defeitos, também em si próprio, ao mesmo tempo em que tem a sensibilidade de perceber isso e a persistência para levar adiante um casamento.

"Mas tudo que acontece na vida tem um momento e um destino'

Operador argumentativo - mas - de mudança de conclusão em relação ao enunciado anterior. Embora tivesse tudo para dar errado, não deu. Com paciência "estamos" juntos até hoje.

Quantificador de generalização - tudo - (Polenz: 1985: 150), provoca uma expressão de vagueza, característica do discurso persuasivo. Acentua o índice de autoridade do conhecimento de senso comum pelo clichê: 'Cada um tem o seu destino', o de L2 e 12 é o amor eterno, o permanecer juntos, apesar dos 
problemas iniciais. Surge o ethos de solidariedade, todos passam por momentos difíceis. Não há como escapar. "Só a paciência ajuda".

Reforça-se a tendência à fatalidade, que já vem sendo construída ao longo do anúncio. Com isso, cria-se um ethos de resignação perante os acontecimentos e também um ethos de inteligência, já que aponta para um possível aproveitamento do que acontece, uma atitude sábia.

'Viver é uma arte, é um ofício. Só que precisa cuidado. Pra perceber que olhar só para dentro é o maior desperdício.'

Verbo substantivado - 'Viver' - sem um determinante, provoca o sentido de generalização (POLENZ, 1985). Funciona como um índice de autoridade, pois vem em forma de clichê, provérbio, dito popular de senso comum, inquestionável. 'Todos sabem que viver é uma arte.'

Operador de gradação - Só - orienta para a negação da totalidade. O uso do 'só' é coloquial, já que ele, na verdade, vai de encontro ao dito 'viver é uma arte'. Justamente porque viver é uma arte, precisa-se ter cuidado. O operador mais adequado seria: 'por isso'. Continua a confirmação do ethos de sensibilidade, de cuidado com o outro, de solidariedade.

'... cuidado. Pra perceber que olhar só para dentro é o maior desperdício.'

Especificação do que o autor acha que é cuidado com o viver. Cuidado para não olhar só para dentro. Dessa forma, retoma o termo 'egoísmo', que foi citado anteriormente, como sendo uma das características pessoais antigas, porém, agora retomada como sendo uma característica que abrange todos, pois vem ligada ao dito: "Viver é uma arte". Continua a chamar a atenção para a importância do outro no relacionamento. Ethos de solidariedade, sensibilidade, inteligência.

Modalizador de restrição - só - modaliza a expressão 'para dentro' e realça o tipo de olhar narcísico que caracteriza o egoísmo, o individualismo. Acentua 0 ethos de solidariedade.

Classe argumentativa - baseada na enumeração de clichês:

'O teu "amor pode estar do seu lado". 
O "amor é o calor que aquece a alma".

'O amor tem sabor pra quem bebe a sua água.'

Fraseologismos - os dois primeiros enunciados são ditos do senso comum, pressupostos como sendo do conhecimento de todos, principalmente os leitores do anúncio - ou ouvintes da música - e que funcionam como bons índices de autoridade. O terceiro enunciado é montado da mesma forma e é assimilado como os anteriores. Assemelham-se a provérbios, sobre os quais não se pensa muito ao ouvir, mas potentes para evocar scripts desejados. L1/Lo, ao construir sua argumentação apoiado nesse texto de L2, que faz uso de chavões desse tipo, busca: criar uma empatia positiva; reforçar o ethos de intimidade, pois a música é do conhecimento de um grande número de indivíduos; criar no inventário perceptual do leitor a imagem de uma marca tão solidária como L2 em sua luta para permanecer junto de 12 , ao mesmo tempo construir sentidos de que os leitores também devem ser persistentes dessa forma.

Índice de ambigüidade - teu, seu - no enunciado 'o teu amor pode estar ao seu lado', uma mistura coloquial entre você e tu que não segue a gramática normativa, aproxima-se do registro falado e fornece ao texto um caráter mais casual e íntimo entre locutor e leitor e ao mesmo tempo provoca uma certa ambigüidade, pois não se sabe ao certo a quem ele se dirige.

'Eu 'hoje mesmo quase não' lembro que já estive sozinho.'

Dêitico - hoje - impossível de determinar, pois não se tem idéia de quando o texto foi escrito, funciona como atualmente. Torna possível o leitor inscrever-se no texto, como sendo o seu aqui e agora.

Modalizador - mesmo - que acentua o dêitico 'hoje' em relação ao passado.

Operador - quase não - que orienta para uma gradação, no caso em direção ao positivo, já que enfraquece a negativa total.

'Que já estive sozinho' - é a lembrança, modalizada por 'quase não'. Não é uma lembrança a ser cultuada. A solidão não é bem-vinda nesse anúncio. Ethos de credibilidade, já que mais uma vez se expõe fazendo confissões. No senso 
comum, estar só é sinônimo de ser infeliz. Por isso, o uso do 'quase'. O autor e, portanto, também o leitor devem se lembrar de que houve um tempo infeliz, que era quando estavam sós, para poder avaliar o quão positivo é o tempo atual, quando estão acompanhados. Reforço, desde o início, do estar a dois, da situação de parceria amorosa, construção muito diferente das construções de sentidos do anúncio da Pfizer alemã.

- Que um dia eu seria seu marido, seu príncipe encantado-

Epíteto - príncipe encantado - como foi mencionado na parte teórica, uma das funções do mito é exercer orientação pedagógica. O príncipe encantado, que surge como um aposto de marido, é um personagem de contos de fadas. Leva à construção do script de que o casamento deve ser feliz, eterno e indissolúvel, mesmo que haja problemas, como os que foram mencionados acima ou na atividade sexual do casal, que em nenhum momento foi mencionada na narrativa. Incita o homem e a mulher a lutarem bravamente para conseguir o que é difícil, a superar tempos difíceis nos relacionamentos, sejam eles quais forem. Resgata 0 que foi dito acima sobre 'destino': cada um tem o seu, assim como o 'príncipe encantado', cada um deve ter o seu, basta saber olhar para o lado.

'Ter filhos, nosso apartamento, fim de semana no sítio. Ir ao cinema todo domingo só com você do meu lado.'

Classe argumentativa - enumera desejos do ser humano, parte do imaginário da maioria da população, para a qual esses elementos fazem parte da felicidade de um casal = casa, filho, posses, lazer. Se lembrarmos o anúncio brasileiro da BASF, onde aparecem as necessidades básicas do ser humano, pode-se ver que aí elas também são citadas: instinto de guarida, com a inovação da vontade de acumulação e reprodução e lazer, já que o instinto de sobrevivência está garantido. É o coroamento de uma relação que, apesar de ter começado com tantos problemas - egoísmo, chatice, implicância, temperamento difícil, esquisitice -, consegue permanecer viva. 
'O amor é o calor que aquece a alma.'

Repetição do enunciado que foi dito acima. Funciona como uma ladainha, reforçando a indução à conclusão: o amor vale qualquer sacrifício. É algo divino, ligado à alma. E é preciso ter muita paciência para poder alcançá-lo. É um arremate para a linha de argumentação baseada em senso comum, clichês, ditos populares, no qual o autor Nando Reis e por tabela os locutores da agência e a Pfizer se apóiam para poder inserir os argumentos necessários. Estes devem conduzir o leitor para a conclusão que: o casal é a base do amor, o amor é constituído não de egoísmo, temperamento difícil, esquisitice, chatice etc. O amor é solidariedade, é ter filhos, construir casa, patrimônio, ter lazer etc. É não pensar só em si. É ver que o outro também tem problemas e participar deles etc.

A relação sexual entre o casal, que está subentendida, é vista como parte de uma relação amorosa que inclui dois indivíduos e abrange, além da sexualidade, mais elementos que devem ser preservados. Não há figura de virilidade que indique ethos de potência. Ao contrário, aparece uma figura masculina aparentemente sensível, vulnerável, abnegada para a companheira, feliz com a sapiência trazida pelo tempo e resignada com o destino, que, possivelmente, é a sua disfunção peniana, não mencionada nenhuma vez no anúncio, mas sempre presente por intermédio do logotipo da Pfizer.

'Para Nando Reis, paixão significa estar do seu lado.

O dêitico 'seu' é a forma de trazer, definitivamente, o leitor para dentro do anúncio. 12 funde-se a 11 Esse texto de Nando Reis passa, definitivamente, a ser entre L1/lo e o leitor, intermediado por L2 e I2. Parece que podemos ver o dedo do L1/Lo apontando para o leitor. A mão modalizada do personagem masculino do anúncio tem agora o seu complemento lingüístico. Todos fazem finalmente parte dessa construção de sentidos e a névoa da imagem visual iguala-se à nebulosidade da dispersão do sujeito entre todos os seus representantes nesse texto.

Índice lexical de avaliação - Paixão - a Pfizer parece confundir, intencionalmente, as palavras amor e paixão, sem se preocupar em deixar claro 0 
que uma e outra significam. Paixão teria a conotação de obsessão, de algo que se sobrepõe à razão, enquanto amor seria algo mais calmo, controlável, produtivo e assimilável pela nossa sociedade.

Começando o anúncio com a palavra "paixão", e fechando-o com "paixão" e "prazer", estaria emprestando mais "fogo" à peça publicitária, que até então acentua situações bem assexuadas, como: destino, arte, alma, amor antigo, ao seu lado, água, marido, príncipe encantado, filhos, apartamento, sítio e cinema.

Estas duas últimas palavras - "paixão" e "prazer" - teriam mais a ver com sexo, do que simplesmente "amor", que pode ser fraterno, meigo, maternal, que são as construções de sentidos veiculadas pela letra de Nando Reis. E o curioso é o texto anunciar "a paixão segundo Nando Reis" já que o artista não usa o termo uma única vez. Daí a "decisão" de citar a palavra já depois das aspas, três vezes, e ainda "apimentado-a" com a expressão "muito prazer". Constrói-se, com essa peroratio, a possibilidade de criação de sentidos menos sentimentais do que o que foi feito no decorrer da narrativa. Isso permite a entrada de um exercício de sexualidade mais ativa, mais instintiva e, portanto, menos institucional do que o texto da música de Nando Reis deixa supor.

Interdiscursividade - o termo 'paixão' admite outras conotações.

O começo do anúncio: "Paixão segundo Nando Reis", pode remeter à 'paixão de Cristo', paixão segundo a Igreja Católica etc. Além da intertextualidade 'constitutiva': 'Paixão segundo...' surge também uma interdiscursividade. Percebese, nesse caso, a interdependência de formações discursivas que servem tanto para o senso comum sobre amor cotidiano como para formações discursivas religiosas, fatalistas: "Amor é o calor que aquece a alma", "[a vida/ o amor/ a família] precisa de cuidado", "tudo na vida tem um momento e um destino".

A argumentação do texto cria sentidos que indicariam para a conclusão de que paixão pode ser entendida como ‘doação de um para o outro', de abnegação do ser que ama para a felicidade do outro. Esquecendo seu egoísmo, esquisitice, aceitando a chatice, temperamento difícil etc. Paixão, segundo a ideologia cristã, não tem a conotação de prazer. Pelo contrário, indica dor, resignação ao martírio 
em nome de um ser maior, um amor, uma união que foi abençoada e não pode ser quebrada.

A argumentação remete, também, à aceitação do destino que cabe a cada um, mesmo que seja difícil. Por isso o uso, bem claro, de fraseologismos de cunho popular, de fácil assimilação e pouco questionáveis. Essa interdiscursividade que torna presente esse discurso religioso, contrói no o anúncio um ethos de humanidade, baseado mais em 'com/paixão' do que em solidariedade ou sexualidade.

'Para a Pfizer, paixão é o que faz a gente pesquisar as curas para os males que afetam a qualidade de vida dos homens e das mulheres.'

Construção enfática - é o que faz-

Inscrição do sujeito - a gente - coloquial a serviço de uma intimidade no diálogo. Pode ser entendido como um 'nós corporativo', ou seja, todos os que fazem a Pfizer, como se fossem uma grande família. Por isso, o uso do coloquial 'a gente', destinado não só a apagar conflitos, como também a inserir o maior número de indivíduos no discurso de solidariedade da Pfizer.

Pode ser considerado, também, como um índice de polifonia, por intermédio de um 'nós excludente', isto é, um 'nós' que inclui os que fazem este tipo de pesquisas, em oposição ao que não fazem, isto é, aos outros laboratórios que têm medicamentos similares no mercado.

A Pfizer, nesse momento, como já foi discutido, assume claramente o discurso como sendo dela própria. Com isso adiciona o ethos de competência, seriedade, demonstrando uma capacidade científica que dá conta de 'curar males' que ainda não são nomeados, apesar de ser o final do anúncio. A partir desse momento, há, com a introdução desse enunciado, uma construção acentuada de um ethos de humanidade, uma situação de auxílio do mais forte para o mais fraco, do cientista poderoso que detém o conhecimento através das pesquisas, para os que sofrem de males que não podem ser nomeados.

Fraseologismos - de homens e mulheres - constrói um ethos de solidariedade entre o casal, reforçado pela presença do círculo azul sobre as 
cabeças do casal da foto. Permite-nos criar sentidos para a interpretação do que se trata esse anúncio, ao mesmo tempo em que conduz o leitor à criação de scripts de exercício de sexualidade entre casais 'casados, heterossexuais, que se amam, que se juntaram para construir uma vida comum, eterna e inseparável, pois durante a narrativa, a ênfase caiu sobre o ethos de solidariedade, já que o autor falava com sua esposa, alguém em igualdade de condições.

'E a gente faz isso todos os dias.'

Subentendido - Há a introdução de um certo índice de malícia com esse enunciado. Encadeado dessa forma, com o operador argumentativo 'e' servindo de cópula com o enunciado anterior, deixa subentendido que, assim como o trabalho de pesquisa é diário, o auxílio para os que necessitam do uso do medicamento para esses males também é diário. Cria sentidos, que deixam subentendidos que, com o medicamento, pode-se fazer sexo todos os dias, e se faz, de acordo com o enunciado na afirmativa, proporcionando com isso uma melhor qualidade de vida.

'Com paixão'.

Subentendido - Sexo apaixonado, não só amor institucionalizado, citado ao longo do anúncio. Apimentado ao ser traduzido pela Pfizer o que significa amor para Nando Reis.

Mas leva também à possível compreensão de que a Pfizer tem 'compaixão' pelas pessoas que sofrem desse problema. Volta ao discurso religioso, que remete à Paixão cristã, religiosa, de ter compaixão com os que sofrem. Assim como o leitor, talvez, deva ter compaixão pelas pessoas que sofrem de disfunção peniana e, portanto, paciência, solidariedade, humanidade. Discurso que foi sendo preparado ao longo do anúncio.

'Muito Prazer, nós somos a Pfizer'.

Figuras retóricas - Paranomásia - esta figura se caracteriza por uma pequena mudança de algumas letras de uma palavra (SPANG, 1987). Nos termos 
'prazer' e 'Pfizer', os sons se encontram em 'p' e 'zer' e se levarmos em consideração que se pronuncia 'Pfaizer' teremos ainda o 'a' para reforçar a ligação entre ambos. Pfizer passa a lembrar 'prazer' e vice-versa. Acrescenta-se ainda que o termo 'Paixão' pode ser adicionado a essa figura de repetição de sons, complementando com aliteração. Temos então: "Paixão, Prazer, Pfizer". Esse é um dos componentes do inventário perceptual ao qual a Pfizer deseja ser ligada.

Fraseologismo - muito prazer - Expressão fraseológica usada em ato rotineiro. Rotina é definida por Lüger (1993, p. 7) "como procedimentos repetitivos, fixos, que estão à disposição dos agentes como soluções prontas para problemas" ${ }^{\prime 2}$. Trata-se de expressão lingüística acionada quando os interlocutores são apresentados pela primeira vez uns aos outros.

A função dessas formas lingüísticas, relativamente fixas, automatizadas, é simplificar as situações de interação, permitindo que os interlocutores se concentrem nas informações que interessam. Essas fórmulas evocam scripts nos quais seu uso ocorre. Muitas vezes essas formas são tão automatizadas que os termos têm seus significados ou enfraquecidos pelo uso ou completamente perdidos.

O anúncio inova ao acrescentar à expressão 'muito prazer' outro sentido. Isso provoca um subentendido, condicionado ao tipo de remédio produzido pela Pfizer, que provoca ereção e é capaz de proporcionar prazer sexual. É essa nova conotação que interessa à Pfizer, fazer a ligação do medicamento ao prazer por ele proporcionado, sem no entanto, agredir o consumidor. É isso que a Pfizer deseja aos seus leitores: Muito prazer sexual. Seja feliz sexualmente, tendo ereções proporcionadas pelo remédio Viagra produzido pela Pfizer.

Inscrição do sujeito - nós - o mesmo nós corporativo do qual a BASF faz uso em suas publicidades. Age excludentemente, pois não se tem idéia de quem faz parte desse 'nós', atualmente muito moderno, a fim de que os funcionários 'vistam a camisa' da empresa, como se esta fosse sua. Encobrem-se, dessa forma, relações assimétricas de poder. Além do fato de provocar o que Brandão

28 "...als verfestigte, wiederholbare Prozeduren, die den Handelden als fertige Problemlösungen zur Verfügung stehen". 
(1991: 455) coloca como "amplificação do círculo do emissor", podendo facilitar a inclusão e, portanto, a identificação do leitor com a Pfizer.

\section{Inventário Perceptual Mitológico}

Embora seja um anúncio sobre medicamento para a mudança de uma situação não desejada, há uma carga acentuada de elementos de mitos que expressam o desejo pela defesa da permanência das coisas como estão.

Embora seja citado o príncipe encantado, não se encontra o herói solitário, desbravador, lutador, que sai a conquistar altas montanhas, mudando situações, trazendo novidades. Surge, na narrativa publicitária, um homem que fala sobre como é bom ter uma mulher que o acompanhe perante dificuldades.

Cultiva-se o herói do imaginário feminino, que lhe traz o desejado amor eterno, pacificado, o amor sob o controle das instituições da sociedade. São os heróis como os 'príncipes encantados' que as desposarão e delas nunca se separarão, serão felizes para sempre, não importando que tipo de problema possa ocorrer. Este é o ideal cultivado, no caso do anúncio da Pfizer brasileira.

É a esse inventário perceptual que a Pfizer (Viagra) deseja se ver ancorada no espaço mental do leitor/consumidor. Não se vê nesse anúncio nenhuma composição que traga elementos da 'fêmea insaciável' ou 'donzela disponível'. A figura feminina se funde no modelo da Grande Mãe, mito que expressa compreensão e acolhimento, independentemente dos problemas que possam ocorrer - no caso, problemas sexuais.

É um elemento feminino participativo, poderoso, pronto para investir na manutenção de seu 'círculo ao redor do fogo familiar'. Mesmo que isso coloque em risco parte de sua felicidade.

\section{Conclusão parcial}

Não há um título destacado visualmente, nesse anúncio, que chame a atenção do leitor imediatamente, como nos analisados anteriormente: por exemplo: 'Ich will. Ich kann'. O texto aparece inserido como um bloco iconográfico único, maciço, que cai sobre a foto como uma cortina translúcida, deixando o 
casal por trás. Estrategicamente, no entanto, essa cortina de letras termina antes de encobrir também o slogan do anúncio e o logotipo da Pfizer. O círculo azul sobre os rostos colados do casal tem a mesma tonalidade do retângulo que contém o slogan "Muito prazer, nós somos a Pfizer. Aí volta a ser usado o azul de outros anúncios da Pfizer, o azul do Viagra.

Logo na primeira linha, surge o índice de intertextualidade manifesta por intermédio do enunciado 'Paixão segundo Nando Reis', que pode ser considerado como uma introdução. Apóia-se na apresentação cuidadosa do que Nando Reis, que é famoso, pensa que é amor. Isso é a forma de apelar para a atenção do leitor, fazendo o papel de um exordium. Aposta-se no fato de que o leitor já conhece o compositor, a letra, de que gosta da música e, portanto, provoca a empatia imediata que avaliza o que vai ser adicionado ao longo da argumentação visual e lingüística.

Além disso, o texto segue com uma outra função. O fato de que os leitores já conhecem o texto faz com que o mesmo não tenha a necessidade de ser lido por inteiro, funcionando como âncora para algo que já estaria na mente do leitor. Assim, ele funciona cognitivamente da mesma maneira que visualmente, isto é, como um bloco, como se fosse um fraseologismo que evoca o script sobre o qual a letra trata: uma vida a dois, com dificuldades, perseverança etc. Isso possibilita que os leitores não sejam obrigados a lerem o texto todo para saber do que se trata, podendo ir direto para o final do anúncio, ganhando tempo, algo tão precioso para a publicidade.

Os enunciados que compõem o texto de Nando Reis são truncados, separados por ponto final, estratégia que, ao longo do texto, provoca a sensação de não haver uma seqüência lógica de pensamento. Parece ocorrer, por um fluxo de consciência, um amontoado de lembranças, um apanhado de frases feitas, apoiadas no senso comum, que sustenta, de acordo com o imaginário popular, o que devem ou deveriam ser os componentes de relações amorosas duradouras.

Essa estratégia argumentativa, isto é, o uso de fraseologismos de cunho popular, também contribui para abranger o maior número de leitores que, inevitavelmente, acabam por se identificar, se não com todos, pelo menos com 
alguns dos enunciados. Isso dilui ainda mais o sujeito nesse conhecimento que pertence à comunidade, que veio antes dele e é, portanto, inquestionável.

Não é difícil o leitor entrar nesse jogo de lugares comuns, já que o sonho das mulheres - ainda segundo o senso comum - é encontrar o 'príncipe encantado' ou o par complementar da 'bela adormecida' que abnegadamente aceita a união eterna, independente das dificuldades. Esse jogo de conhecimentos partilhados mobiliza componentes emocionais de pertencença à comunidade e é usado para fazer a transferência para uma solidariedade em face a problemas de ordem afetiva, fisiológica, vividos por parceiros em relacionamentos afetivos.

A peroratio ocorre a partir do que parece ser o segundo índice de intertextualidade manifesta, que na verdade é uma re-elaboração do que foi dito por Nando Reis. Lo/L1 se apossam do texto de L2 como se fossem resumi-lo e redirecionam para outros sentidos, contextualizando a letra dentro do anúncio. Com isso o jogo de esconde-esconde do que o anúncio realmente tenta vender traz de volta o tema paixão, lançado no início.

A existência de formações discursivas que nos enviam para a esfera discursiva de amor institucional, religioso, de tolerância com dificuldades, companheirismo etc., faz com que surja, no anúncio, um discurso híbrido, embutido de um ethos de humanidade do qual o leitor não se dá conta, mas que é importante para a construção de sentidos desejados pelo anunciante, isto é, um amor que no fundo é patrimônio econômico, genético, com direito a lazer, reconhecido pelas instituições da sociedade.

Pode-se, desta forma, preservar a face da empresa, que trabalha com um medicamento que possibilita prazer sexual sem o necessário vínculo religioso com a procriação. Por isso o jogo de esconde-esconde entre os termos amor e paixão, reproduzidos visualmente por intermédio de triângulos e insinuações de sexualidade, juntamente com casais amorosamente abraçados, olhando em direção ao futuro, imersos em uma névoa e envoltos pelo círculo 'azul-viagra'., culminando com o slogan "muito prazer...", na primeira linha, e "....somos a Pfizer.", na segunda. 
O excesso de vozes dentro do anúncio é extremamente efetivo para que os leitores não consigam identificar, claramente, de onde vem esses discursos que criam essa narrativa que veicula o que a Pfizer produz. Isso dá um caráter vago e abrangente ao que é anunciado. O que, aparentemente, se anuncia é a Pfizer. Isso parece ser a publicidade da imagem da empresa. Mas, na verdade, é publicidade do Viagra, o que pode reconhecido pela presença do círculo azul sobre a cabeça dos personagens, assim como dos elementos visuais e lingüísticos subentendidos.

Esse texto é um exemplo do que é dito por intermédio de silenciamento. $\mathrm{O}$ discurso como fato histórico e social e, portanto, o que pode e o que não pode ser dito, em uma determinada época e lugar. Daí a necessidade de um longo e empolado texto, com múltiplos sujeitos inscritos no discurso, a fim de criar uma estratégia de dispersão, em função da preservação de face da empresa, a fim de que esta não corra o risco de desagradar parte dos segmentos sociais, como igrejas, segmentos conservadores da sociedade ou indivíduos para quem o assunto é doloroso.

Comprova-se que existe um tabu sobre o qual não se pode falar claramente, que vem a ser a dificuldade de ereção peniana. Por isso o uso metafórico de todos os problemas que podem conter um relacionamento amoroso, um casamento, isso tudo por intermédio de fraseologismos de domínio popular, vinculados ao senso comum, de fácil aceitação e sem probabilidade de questionamentos por parte dos envolvidos.

A Pfizer busca, dessa forma, preservar-se de possíveis críticas quando desvincula o sexo do instintivo e o liga fortemente ao amor e, principalmente ao amor institucionalizado. Estratégia muito diferente da escolhida pela Pfizer alemã, que coloca todo o peso da resolução do problema nas mãos masculinas, sem contar com o companheirismo feminino, nem com o discurso religioso de abnegação. 


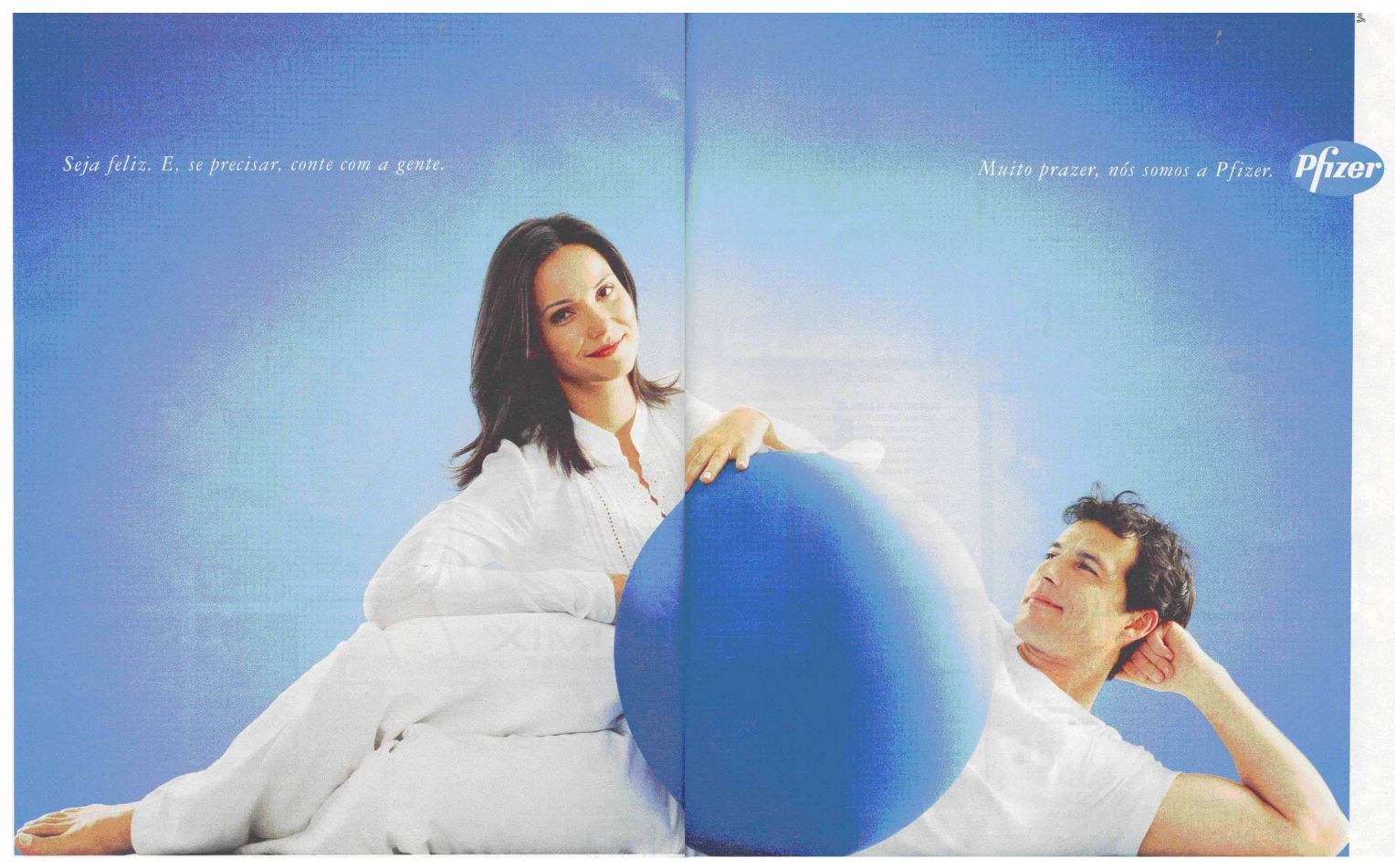




\subsection{2. anúncio - Veja $14 / 12 / 05$}

Análise da composição visual do anúncio - A foto é de um casal branco, aparentemente com boa situação social, beirando os trinta anos. O homem está deitado, com a cabeça apoiada pelo braço esquerdo e o punho cerrado, com olhar dirigido para a mulher, com sorriso tranqüilo e feliz. A mulher está sentada e apoiada nas pernas dele. Olha para o leitor com expressão segura, feliz. Os dois parecem exibir um olhar de satisfação.

A cabeça feminina funciona como um vetor a orientar para o título: "Seja feliz. E, se precisar, conte com a gente". Por sua vez, a cabeça masculina é o vetor a orientar para o slogan e o logotipo que vêm em cima, no lado direito.

O pano de fundo do anúncio é degrade, indo de um azul mais escuro na periferia até se tornar quase branco no entorno do casal. Esse fundo azul do anúncio funciona como um céu sem nuvens, sem nenhum tipo de tempestade ou problemas à vista. Se existe alguma possibilidade de problema, este é mantido longe, pois o matiz azul mais escuro fica mais distante do casal, na periferia do anúncio. Quanto mais perto do casal a cor vai clareando, atingindo um tom mais pastel, o que leva à modalização de leveza, criando uma situação paradisíaca. Essa construção argumentativa funciona como uma metáfora visual para indicar que tudo corre bem entre o casal, que tudo está em paz. Começam a ser construídos ethé de solidariedade, intimidade, felicidade.

Ambos estão vestidos de branco, roupa limpa e leve. Isso reforça e complementa o sentido criado acima de paz, de uma coisa meio diáfana, paradisíaca, parecendo lembrar as nuvens que faltam a esse céu tão límpido. Os ethé, acima mencionados, são muito fortes e claros. A eles é adicionado o ethos de pureza, por intermédio dessa brancura metafórica.

O layout do anúncio pode ser representado por um quadrilátero, que é o formato das duas páginas que ele ocupa, tendo ao centro um triângulo, cuja base coincide com a linha de baixo do retângulo, e é formado pela disposição dos corpos dos dois modelos. No centro do triângulo, situa-se um círculo, representado por uma bola azul, bem à altura da pélvis masculina. 
Olhando-se detalhadamente, nota-se que a mão que segura a bola é a da modelo. No entanto, essa mão é colocada de forma bastante ambígua, o que nos leva a perceber, numa primeira olhada, que trata-se da mão direita do homem, inclusive com uma parte do braço da mulher aparecendo como se fosse o polegar do modelo. Só pela posição dos dedos é que se percebe que a mão é da mulher. Esta mão termina por ocupar o centro do anúncio e se dirige ao leitor, da mesma forma que a mão superdimensionada do anúncio anterior também se dirigia.

A parte periférica do fundo tem o mesmo matiz dessa grande bola. $O$ recurso para chamar a atenção do leitor para o medicamento produzido pela Pfizer continua sendo o mesmo dos anúncios anteriores. Há sempre a menção indireta, bem visível do medicamento por intermédio de um círculo azul, uma metáfora visual bem óbvia, para o remédio.

As estratégias argumentativas visuais recorrentes nos anúncios não deixam de chamar atenção por sua obviedade, já que o Viagra serve para proporcionar a ereção masculina. $O$ centro da foto é formado por um grande triângulo, composto pela junção do corpo da mulher e do homem. A Pfizer volta a fazer uso de um dos ícones arquetípicos que remetem à sexualidade humana, o triângulo, dessa vez em sua versão masculina, pois tem a base para baixo e uma ponta orientada para cima. Este se encontra dividido em outros triângulos menores. Um que é formado pela personagem feminina, que tem no antebraço direito a sua base e o outro que chama mais atenção é o triângulo formado pelo antebraço erguido, a cabeça e parte do peito do homem, também com a base para baixo. Vide anexo 4.

$O$ antebraço erguido, com o punho fechado, é usado vulgarmente para representar força ou um pênis ereto. E, por "coincidência", esta é a posição do braço masculino que parece, inocentemente, apoiar a cabeça do personagem.

Continuamos concordando com Key (1990), quando este afirma que, em campanhas tão bem estudadas e caríssimas, o uso desses elementos, que agem subliminarmente, não ocorrem por acaso. Há a intencionalidade de atingir os consumidores onde estes encontram-se mais vulneráveis: seu inconsciente. $E$ esse anúncio faz isso muito corretamente. 
Com o uso subliminar desses elementos arquetípicos, é acrescentado um ethos de virilidade ao anúncio. Preserva-se, dessa forma, a face do leitor que pode apresentar esse tipo de disfunção peniana. Ao mesmo tempo, preserva-se a face de quem pode se sentir agredido com esse tipo de anúncio que faz publicidade de um medicamento ligado ao prazer masculino e da empresa que deve ter o cuidado em não ofender os possíveis leitores desse anúncio. Isso é um visível indicativo de um forte tabu a respeito do tratamento de assuntos ligados a problemas sexuais masculinos.

O que também pode ser considerada uma forma de preservação de face é o detalhe da mão feminina, modalizada por estar colocada no centro do anúncio. Essa é a argumentação central. Ela ostenta uma aliança de casamento bem visível, inclusive abrindo o dedo mindinho para que a aliança seja realçada.

Esse detalhe é uma metáfora visual de formações discursivas religiosas e institucionais. Introduz no anúncio um discurso institucional religioso e legalista, que cria sentidos de que o medicamento propagandeado deve ser usado em sexo institucional, sexo com amor, sexo no casamento, sexo abençoado pelas religiões, sexo heterossexual etc., por isso a conotação tão paradisíaca criada pelo azul e branco, pelos sorrisos. Não é um sexo pelo qual se deva sentir culpa, é um sexo que é de direito, avalizado. E não é a toa que a aliança de casamento está em exposição na mão feminina. É ela, de acordo com o senso comum, que deve carregar a maior parte da responsabilidade por tornar um matrimônio feliz, agradável.

De acordo com uma pesquisa publicada no Jornal do Commercio, do Recife, em (05/03/06), a maioria das mulheres trazem para si a culpa da disfunção peniana. É ela que assume, na maioria das vezes, o papel da Grande Mãe ao tentar manter aceso o fogo cálido do lar, é a ela que cabe ter paciência com o problema e dar proteção ao elemento masculino em horas consideradas tão difíceis. São essas formações discursivas que são, também, introduzidas no anúncio por intermédio dessa mão com aliança na parte central. Note-se que não há preocupação de mostrar a aliança na mão do homem. 


\section{Análise da composição lingüística}

Do lado esquerdo, em cima, observa-se o texto, vazado em tipos itálicos: "Seja feliz. E, se precisar, conte com a gente."

Na mesma altura, do lado direito, encontra-se o slogan:

"Muito prazer, nós somos a Pfizer", antecedendo o logotipo da empresa.

"Seja feliz. E, se precisar, conte com a gente".

Modalização - Seja feliz - feita por intermédio do modo imperativo, a materialização gramatical escolhida pelo locutor. Determina a expressão de uma vontade de ação sobre o interlocutor. Há diferentes maneiras de expressar essa vontade de poder sobre os outros e, dependendo de como é usado, demonstra a relação existente entre os interlocutores. Segundo Sowinsky (1988: 93), "existem diferentes categorias gramaticais para expressar uma exortação, um comando". ${ }^{29}$ Nesse texto, o locutor opta pela forma mais curta, que por não conter modalizações que, normalmente, são usadas para amenizar o comando e preservar a face do interlocutor, fortalece a ordem. O motivo para essa escolha é que esse imperativo é uma ordem de felicitação (positiva), não há necessidade de modalizações amenizadoras da ordem, pois a face do interlocutor não se encontra ameaçada. A conseqüência disso é o surgimento de um índice de intimidade, como se a Pfizer fosse um amigo. Constrói-se, dessa forma, um ethos de solidariedade.

\section{- E, se precisar / "Und wenn Mann will aber nicht kann"-}

que insere uma condição, indicando a possibilidade de nem tudo estar em ordem com o "Ich kann"/ser capaz'. O desejo continua em ordem. O desejo masculino segue normal. Não há a ameaça à masculinidade. O ethos de potência continua intacto. Essa possibilidade de algo não estar em ordem é colocada cuidadosamente como uma hipótese. Esse cuidado é em função da preservação de face do leitor que pode estar sofrendo justamente dessa disfunção erétil.

\footnotetext{
29 “..., dass es offenbar mehere grammatische Kategorien zum Ausdruck von Aufforderungen gibt,..."
} 
Mas, se algo acontecer - e nem tudo correr às mil maravilhas, ou não correr como você deseja, espera -, você sabe onde encontrar ajuda, com quem se conta nas horas difíceis. Essas "horas difíceis" seriam a impotência. Nesse caso "você" pode contar com a Pfizer, que fabrica o Viagra, a "pílula azul", como a cor preponderante no anúncio. O que são essas horas difíceis fica sempre subentendido, em nenhum momento aparece claramente. Mas o anúncio é tão bem construído que, apesar do pouco texto, a intencionalidade de se vender o produto Viagra é clara.

Operador argumentativo- e - de cópula. Esse operador surge, também, para fazer a ligação entre os sentidos que foram construídos na parte visual do anúncio com a parte lingüística. É uma boa prova de que os sentidos criados pelo discurso visual e os criados pelo discurso lingüístico se complementam.

Poderia ser substituído pelo operador adversativo 'mas'. Porém, este mudaria os scripts que foram evocados a partir da ordem de felicidade para scripts com motivos que possam causar infelicidade, introduzindo, dessa forma um índice de pressuposição de que há possibilidades de problemas. Esse índice de pressuposição a ser criado com o uso do 'mas' não é necessário, pois visualmente ele já existe.

O anúncio, tanto lingüística, como visualmente, é pleno de pressupostos e subentendidos. O que permite a criação de diversos sentidos. Não é necessária a discussão das causas. Estas estão subentendidas na própria estrutura do anúncio, já que este é sobre medicamento para problemas de disfunção erétil. Por isso opta-se pelo uso do operador ' $e$ '. Ele torna o enunciado mais fluido e com isso uma maior sensação de intimidade.

Índice de polifonia - se precisar - Está subentendido qual auxílio está sendo oferecido, pois o anúncio é da Pfizer, a empresa que fabrica o medicamento Viagra, 'a pílula azul' tão visível na construção da peça publicitária, existe um casal em situação de intimidade amorosa, com todos os discursos subliminares já analisados. É muito clara a existência de um tabu nesse assunto. Não se fala, não se toca no assunto, embora todos saibam o que possivelmente está ocorrendo. Tem-se um cuidado extremo com a face do leitor ou possível consumidor do 
medicamento. O silêncio provocado por todos esses anúncios chega a ser gritante.

Operador argumentativo - se - indica uma condição, uma hipótese de acontecimento e não uma certeza. Da mesma forma como ocorreu no anúncio da Pfizer alemã: 'Und, wenn Mann will, aber nicht kann', preserva-se a face da empresa ao não deixar que se crie a sensação de que esta age como ave de mau agouro, afirmando que o leitor vai algum dia precisar, caso fosse escolhido o operador 'quando', por exemplo. Preserva-se também a face do leitor. Com isso não pretende afirmar a existência do problema, mas chamar a atenção do leitor para a possibilidade de que 'se' ele ocorrer, a Pfizer tem a solução.

- Conte com a gente - é equivalente ao enunciado alemão: 'Fragen Sie Ihren Arzt!'. Segue o mesmo mecanismo de significação do uso da forma imperativa, usada no enunciado: 'Seja Feliz'. Não esquecendo que imperativo, seja de felicitação, de intimidade ou não, é uma ordem. A modalização ocorre pela própria forma escolhida para materializar a intenção lingüística. A intenção é modalizada por termos coloquiais, íntimos - a gente.

O recurso da introdução desse termo distensiona o enunciado anterior, que havia levantado um possível problema no campo da sexualidade masculina, e cria uma atmosfera de intimidade e confiança entre o anunciante e o leitor, que é o espelho, o reflexo do que se vê na imagem com o casal da foto. Reforça o ethos de confiança, solidariedade, tolerância, já criados visualmente. E introduz os ethé de competência científica e de humanidade, pois subentende ajuda a seres fragilizados pelo problema, já que este é até um tabu sobre o qual não se pode falar.

'Muito prazer, nós somos a Pfizer.'

Da forma como está posicionado, na altura da mesma linha do outro enunciado, este funciona como se fosse uma continuação. Primeiro, o argumento lingüístico, 'E' 'se você precisar'..., logo em seguida, a argumentação visual, e, novamente, fechando com a argumentação lingüística do slogan: 'muito prazer, nós somos a Pfizer'. 


\section{Inventário perceptual mitológico -}

O casal veiculado pelo anúncio leva à conclusão de que o remédio deve ser ancorado, no espaço mental do leitor, a momentos felizes, despreocupados, nada que lembre problemas. As roupas brancas remetem à pureza. A pureza da relação franca, a pureza do sexo tratado como algo saudável, limpo, onde se vincula com o amor e não apenas ao desempenho sexual masculino.

Continua não aparecendo a figura do herói de rosto endurecido, solitário, mesmo quando acompanhado, destinado a resolver seus problemas sem auxílio externo. Pelo contrário, o personagem masculino aparece disposto a buscar ajuda e para isso busca a companheira com o olhar, indicando uma certa dependência da figura feminina. É ela que parece the fornecer o apoio necessário, com seu sorriso calmo e seguro, para vencer estas horas difíceis. Este sorriso é dirigido ao leitor, que também deve contar com ela, a companheira.

A figura que se apresenta com mais força continua sendo a figura da Grande Mãe, a mesma do anúncio anterior, sempre disposta a investir na continuação do par, da família. Porém, não é uma figura assexuada, apresenta-se com uma pitada da força da donzela, em pleno exercício de sensualidade, só que devidamente controlada, como mostra a aliança no dedo anular.

\section{Conclusão parcial}

Nesse anúncio, pode ser constatado que a mulher é chamada a fazer parte do problema e de sua solução. O problema de ereção masculina passa a ser também um problema feminino, já que, de acordo com o senso comum, o casal é sinônimo de solidariedade, partilha de problemas etc. Os olhares são de cumplicidade, de solidariedade. Olhares de quem aprendeu a lidar com o problema e sem medo de discutir sobre eles. Exibem a coragem, de aceitar dificuldades e conjuntamente ultrapassá-las. Tudo pode ser resolvido quando se confia no parceiro.

A bola azul remete ao Viagra. De acordo com a linguagem visual, percebese que o seu tamanho recebe um tratamento hiperbólico, por isso ocupa boa parte 
da página. Além disso, está centralizada e colocada em primeiro plano. Há o contraste claro entre o branco das roupas e a cor da bola. Isto são pistas de modalizações visuais, destinadas a acentuar a importância do remédio, a partir do qual a publicidade toda é elaborada. Porém o nome do medicamento continua não sendo veiculado. Essa estratégia corrobora a idéia de que há uma tentativa de preservação de face do usuário ou possível usuário do remédio, da empresa e dos leitores.

Os sentidos criados pelo anúncio deixam perceber que o assunto é tabu, não se toca textualmente no problema, porém, graficamente há vários índices sobre o tema desse anúncio. Isso dá margem para que os leitores percebam o discurso de acordo com sua formação, sua moral etc. Fica subentendido que o problema existe na realidade ou potencialmente. Também fica claro que 0 ato sexual não é dentro de um contexto do sexo pelo sexo, mas dele enquanto amor, solidariedade, carinho.

\subsection{Comparação entre as publicidades da Pfizer}

Os anúncios veiculados, simultaneamente, na Alemanha e no Brasil, denotam visões diferentes do que pode ou deve ser dito por parte dos que fazem a Pfizer e suas publicidades.

\section{Diferenças}

Pode ser percebido que o anúncio da Pfizer alemã coloca um peso maior no ethos de potência, com figuras de virilidade masculina, apoiando-se na capacidade do querer, do fazer, do agir do indivíduo heróico, que novamente, sozinho, deve lidar com seus problemas: "Ich will. Ich kann." A foto do anúncio alemão explora imagens angulosas, buscando provocar uma sensação de dureza, lembrando os ícones dos super-heróis dos quadrinhos, uma linguagem mais modernizada, que leva em consideração a comunicação midiática. 
No máximo, conta com a figura que pode ser comparada a um mentor, agora a Pfizer, que fornece o amuleto para o seu sucesso, uma vida sexual aparentemente sem problemas graças ao remédio.

Aciona scripts de relação sexual independente de vínculos amorosos ou institucionais. Propaga o sexo como desempenho, como sendo da responsabilidade apenas da figura masculina e dá margens para exercício da sexualidade em outras esferas que não as institucionalmente desejadas. Reforçase um script de solidão e força individual: 'Kraft durch Wille' - o 'famoso querer é poder, é força, é suficiente'.

No anúncio alemão, não existe uma preocupação, digamos legalista, para o sexo. Essa discussão aparece como sendo da alçada do leitor, como um assunto 'seu' e que depende 'só' dele para ser resolvido. Não se realça se o sexo é por amor, por paixão, por compaixão, se é entre casais casados, se é 'comportado', tanto que no seu anúncio, o homem aparece por trás da mulher. Esse assunto é meramente masculino e a sua solução só a ele interessa.

A figura feminina aparece como não tendo muito a opinar sobre o assunto. De olhos fechados, surge apenas como receptora e não como coadjuvante na busca da solução do eventual problema. Alheia, não aparenta trazer para si um possível sentimento de culpa, nem mostra ter sido atingida pela dificuldade que 0 homem possa estar vivenciando.

A figura feminina não é usada para compor sentidos que the dêem um ethos de solidariedade ou mesmo de humanidade. Como forma de auxílio para o problema são criados os ethé de competência e solidariedade a partir da introdução da figura do médico, o que também implica discrição, segredo, profissionalismo.

Todos os sentidos levam à conclusão de que o personagem-herói, não apenas conta com as propagandeadas possibilidades científicas para resolver os seus problemas, como também carrega, solitariamente, a responsabilidade da sua resolução. É um árduo trabalho.

No Brasil, a construção de sentido que mais sobressai, nos anúncios analisados, é o valor que é dado às relações de compreensão e cumplicidade 
entre os casais. $O$ anúncio investe na sensação de segurança proporcionada pela proteção de um lar, para que juntos se vençam os desafios. A discussão é mais coletivizada, abrandada com o uso de termos genéricos, açucarados e românticos que levam à associação com um script de 'casal feliz'. Isso ocorre com a paráfrase visual por intermédio de um casalzinho perdido no fundo do anúncio em posição igualitária, homem e mulher lado a lado, solidários, em uma atitude protetora. $\mathrm{O}$ texto não fecha com um eu afirmativo "Eu quero. Eu posso", mas de modo suave e coletivo, diluído: "... paixão é o que faz a gente pesquisar as curas para males que afetam a qualidade de vida dos homens e das mulheres."

Investe-se na criação de sentidos que realcem como a mulher não apenas tem importância na relação como também aproveita do que isso possa proporcionar de bom: "... afetam a qualidade de vida dos homens e das mulheres" Constrói uma companheira que compreende o problema e, abnegadamente, procura perceber os lados bons do relacionamento para poder compensar insatisfações causadas por problemas sexuais. Nos anúncios brasileiros, opta-se pela construção dos ethé de solidariedade e humanidade para a figura feminina, que aparece como essencial para a felicidade da figura masculina.

Há um jogo com o termo paixão, que implicaria, também, paciência com a dor, de si própria e do parceiro, já que existe uma relação institucional a ser preservada e que é eterna. Essa perenidade da relação é demonstrada em vários índices, como alianças de casamento (vide o anúncio em que a modelo aparece exibindo a aliança na mão esquerda), textos sobre família, filhos (vide o anúncio com a letra de Nando Reis). Esses elementos acionam scripts muito diferentes dos scripts acionados no anúncio alemão. No Brasil se deixa claro que o sexo é um componente de um relacionamento amoroso, da paixão e do casamento religioso indissolúvel.

Pode-se supor que por sermos considerados um país com características culturais onde as atividades e regras religiosas têm uma grande força de organização da sociedade, sejamos mais conservadores no quesito 'sexo'. Uma comprovação disso é a tentativa de colocar em ação um discurso que traz elementos desse discurso religioso para o contexto da discussão sobre o Viagra. 
Ao mesmo tempo esse conservadorismo pode ser visto como resultado de um comportamento patriarcal mais declarado, mais claro. Sendo necessário a construção do texto a partir de argumentos com mais voltas, mais 'legalistas', antes de ir ao tema. Há que se assegurar muito bem de que a face desse consumidor religioso, conservador em seu comportamento patriarcal, não se sinta agredido ao usar o remédio para disfunção erétil, tida como ameaça a sua virilidade.

Esse comportamento religioso e patriarcal levaria a uma construção argumentativa que realça o valor da família, dos laços indissolúveis do matrimônio e da resignação, tanto feminina como masculina, em relação aos problemas relacionados ao sexo. Ao mesmo tempo em que constroem sentidos, no final, depois de ter preservado as faces dos envolvidos no tema, que permitem a possibilidade de uma relação sexual prazerosa. Tudo, porém, dentro dos parâmetros estabelecidos como aceitáveis.

Ao mesmo tempo, segundo os produtores dos anúncios brasileiros, essa figura masculina é apresentada como tendo necessidade de apoiar-se na figura arquetípica da Grande Mãe, para ajudá-lo na resolução de um problema. Problema que é resolvido com o uso do arquétipo do herói pelos produtores alemães. Se fosse para traduzir os scripts evocados pelas duas publicidades, a alemã e a brasileira, em um fraseologismo, o script brasileiro evocado é o do fraseologismo 'A união faz a força'. O alemão é "Kraft durch Wille"/ 'A força do querer'.

As publicidades anteriores brasileiras sobre o Viagra foram construídas com ênfase no desempenho. Isso pode ser comprovado com a publicidade veiculada na revista VEJA (16,/julh/2003). O exordium dizia o seguinte: "Desempenho sexual com segurança como nenhum outro" (sem vírgulas). Mas, parece que essa estratégia não foi adequada para o público brasileiro, ao longo de sua convivência com o Viagra.

Aparentemente, de acordo com esses anúncios anteriores, a 'potência sexual' era um problema masculino e uma questão de desempenho. O que provoca uma associação com "rendimento de uma máquina". Era a euforia da 
descoberta do Viagra. Um artigo da revista Veja (14/12/04) tem como título: "A euforia passou" e no meio surge a pergunta: "Será que um enorme contingente de homens desistiu de melhorar sua performance sexual?" A resposta é fornecida por um artigo na revista 'ISTO É' (12/10/05: p. 52). Em uma pesquisa, feita pela comissão de Sexologia da Federação Brasileira das Associações de Ginecologia e Obstetrícia, financiada pelo laboratório Pfizer, constatou-se que o número de mulheres $(92 \%)$ felizes com o remédio é maior do que o dos homens. Para complementar, em um artigo no Caderno Família do Jornal do Commércio, do Recife (05/03/06), aparece a constatação de que grande parte das mulheres sentem-se culpadas com a falta de desejo masculino.

Com certeza, com os resultados destas pesquisas nas mãos, os anunciantes brasileiros passam a enfatizar a ligação direta entre amor e sexo, um comportamento mais característico da figura feminina, do que a maioria dos homens, dentro desse tipo de atividade. Dessa forma, trazem a mulher para dentro da discussão da sexualidade masculina. Os anúncios brasileiros criam sentidos que levam à conclusão que as mulheres são co-responsáveis pelo relacionamento sexual, que elas devem investir e ter coragem de buscar ajuda para seus companheiros. Tudo isso em nome da família, amor, renascimento de sexo, manutenção da relação. Os anúncios trazem os problemas para o casal, porque sexo, com afetividade seria algo que diz respeito aos dois.

\section{Semelhanças}

Os textos das publicidades analisadas de Viagra e BASF se assemelham em alguns sentidos.

Os anúncios da Pfizer, tanto no Brasil como na Alemanha, apresentam semelhanças quanto ao tratamento do tema como tabu. O mito masculino da potência não pode e nem deve ser quebrado, nem no Brasil - considerado por muitos um país machista -, nem na Alemanha - considerada por muitos um país mais avançado em relação à sexualidade e onde o machismo seria menor.

Pode-se dizer, no entanto, que o medo de tratar um assunto como a impotência é semelhante nos dois paises. 
Nos anúncios analisados, em nenhum momento é citado o nome do medicamento, nem do problema a ser resolvido com seu uso. Não é citado nem o termo problema. Em ambos os países, tudo isso é falado de forma extremamente cautelosa e velada, fazendo uma argumentação reticente. As publicidades sempre partem de uma narrativa que sugere um sexo sem problema e desviam para uma segunda, que leva para uma possibilidade de um sexo que 'pode' ter problemas.

Aparentemente ainda não está na ordem do discurso (FOUCAULT, 2000) falar diretamente sobre 'impossibilidade de ereção'. Segundo esse autor, entre os assuntos que sofrem interdição, estão alguns relacionados à sexualidade. Os anúncios nos dois países vêm a confirmar isso. Nota-se, em ambos os países, a necessidade de uso de outros tipos de linguagem, que revelem do que se trata a publicidade. A cor azul é usada, sempre, com o intuito de lembrar 'a pílula azul', assim como o layout nos dois países buscam expressar-se por formas geométricas arquetípicas que levem o indivíduo, inconscientemente, a perceber padrões de sexualidade.

Esses anúncios, tanto na Alemanha como no Brasil, são uma demonstração de que o silêncio é muitas vezes mais importante do que o que é dito. O que está sendo calado nesse discurso, isto é, o que veladamente aparece através de muitas voltas é o verdadeiro discurso. O discurso da impotência; do questionamento da virilidade, dentro de sociedades nas quais essa é uma das características mais marcantes masculinas; do problema sexual com os quais os homens e mulheres têm dificuldade de se relacionar.

É o que afirma Barthes, citado por Vogt (1989: 64) durante uma entrevista: "..., talvez, todos nós revelemos mais através das palavras que evitamos do que através das que empregamos". 


\section{CONSIDERAÇÕES GERAIS: O COLETIVO E O ÍNTIMO EM DOIS MUNDOS DIVERSOS.}

$\mathrm{Na}$ análise realizada durante este trabalho, percebeu-se que os títulos dos anúncios publicitários brasileiros são mais extensos e aparentam ser mais didáticos que os alemães. Um estudo mais aprofundado, objetivando comparar apenas esse item, pode ser encarado como um bom assunto a ser pesquisado, onde buscar-se-ia identificar, dentro de um corpus maior, se tais características seriam uma ocorrência sistemática ou não e quais os possíveis motivos dessa ocorrência. E se esta é uma característica da língua alemã em relação à portuguesa, o que faria com que os publicitários escolham uma forma mais concisa de expressão ou se essa forma de materialização lingüística é um sinal de que o leitor alemão exige uma abordagem diversa. Caso contrário, que motivação(ôes) existiria $(\mathrm{m})$ por trás dessas diferenças.

Será que essa forma de abordagem didática dos anúncios brasileiros da BASF, analisados nesse trabalho, poderia ser considerada 'desagradável' ou até mesmo 'ofensiva' aos consumidores alemães, que não desejam sentir-se ensinados, direcionados, didaticamente, a ver algo? Provocaria uma dificuldade de identificação pelo fato de não desejarem ser retratados como 'tutelados', 'tutela' essa que fica tão clara no anúncio brasileiro? Nota-se, portanto, logo no título, um tratamento diferenciado dado os leitores dos dois países.

Do que se depreende que, para os interlocutores alemães, poderia surgir uma dissonância cognitiva, não só no título como também em todo texto e concepção dos anúncios, que parecem um pouco didático demais, no caso brasileiro. Tal bordagem poderia ir de encontro à imagem que os alemães têm de si próprio, que se achariam capazes de ver as coisas por si mesmo. Há que ser indireto em sua forma de falar. O consumidor alemão pode não ver a origem desse auxílio da BASF a suas vidas, porém, é capaz de ver suas conseqüências, tanto que a empresa entraria como um mentor que facilita e não como um professor.

Quanto à estratégia retórica, percebeu-se recorrência da mesma abordagem usada pelas publicidades nos dois países. Existe uma repetição 
sistemática tanto das composições visuais dos anúncios como, também dos temas básicos escolhidos para serem apresentados em cada país.

Detecta-se o uso de trechos inteiros comuns aos anúncios; a escolha repetitiva e cuidadosa de vocábulos; o mesmo tipo de léxico que realça o inventário perceptual ao qual a BASF deseja se vincular; o uso de lugares-comuns como figura de autoridade; os mesmos jogos de cores, contrastes, indicações vetoriais, além do slogan. É como se fosse um processo de condicionamento pavloviano. Os anúncios são imediatamente detectados como sendo da BASF, tanto no Brasil como na Alemanha.

Essas repetições sistemáticas, como já foi visto, são feitas com o intuito de dificultar possíveis discordâncias, além de serem elaboradas com a finalidade de criar uma intertextualidade que se torna muito proveitosa, pois esta é usada de forma a condicionar o leitor a, imediatamente, detectar qual anunciante está ali representado e, ao mesmo tempo, evocar os diversos scripts já propostos pelos anúncios anteriores. Há uma economia de tempo muito eficiente.

Isso facilita para o leitor o reconhecimento imediato dos 'amigos' e dos 'inimigos' eleitos para reforçar a potência do que é anunciado. Para detectar os primeiros, opta-se pelo uso de palavras que demonstram segurança, competência, conhecimento tecnológico, fidedignidade, liderança, características que fazem da BASF o grande amigo, com quem se pode contar para se enfrentar um 'inimigo'. A esse inventário perceptual a BASF se liga nos dois países.

Se a estratégia global de argumentação é a mesma, os 'adversários' eleitos, porém, são diferentes. Portanto, as escolhas das figuras para representar esses inimigos devem diferenciar-se. Pelo que pode ser percebido, pelos acordos que transparecem nos anúncios analisados, o enfoque da natureza é muito diferente nos dois países.

No caso dos anúncios da BASF alemã, o 'adversário' é o meio ambiente hostil ao ser humano, porém um inimigo que aparece em seu estado bruto, intacto, com sua grandiosidade e pureza original conservada, ainda com seu poder de submeter os homens a dificuldades mortais. É um inimigo poderoso, digno, que deve ser admirado e respeitado, com o qual deve-se aprender a 
conviver. E por isso a BASF é necessária, para ajudar o personagem em sua conquista, não para domesticar a natureza, mas para que o herói possa conviver com ela e saia ainda mais valorizado, pois, quanto mais digno o inimigo, maior o ato de heroísmo. A natureza, no anúncio alemão, tem a função de engrandecer o feito do herói e a competência tecnológica do mentor.

Nos anúncios brasileiros da BASF, não há espaço para heróis. Neles são representadas crianças que evocam scripts de proteção, adultos em situações idílicas, evocando scripts de felicidade. Embora as imagens representem estados idílicos, os textos deixam transparecer que o paraíso está ameaçado. O inimigo é representado pelo risco que corre o meio ambiente e pelo meio social em desarmonia. E ambos são igualados e mostrados como se beneficiando do engajamento social e humano da BASF, o que comprovaria sua sensibilidade.

A natureza aparece como domada, circunscrita a ser olhada da janela ou, no máximo, usada para um aprazível piquenique feito por crianças. Aparece transformada em gramados, tendo matas bem pouco grandiosas para serem admiradas. Em seu texto, não se fala de 'ventos e tempestades', pelo contrário, a notícia que se tem desta natureza é que ela já foi submetida às ações humanas predatórias, é demonstrada como impotente, prestes a ser destruída, encontrando-se em estado que necessita de ajuda.

Assim como a natureza, também necessitam de ajuda as comunidades que nela vivem. Fala-se em 'comunidades carentes', 'projeto Crescer', 'desenvolvimento social'. Por isso a vinculação da BASF com um discurso patriótico, no qual ela chama para si a incumbência de participar na restauração do que foi destruído. Ela é a possibilidade da criação de uma comunidade que tenha 'qualidade de vida', como a representada nas fotos.

A BASF coloca-se como possível coadjuvante nessa tarefa reestruturadora da paz social e ambiental. Dessa forma, é possível atrair a empatia do leitor brasileiro por intermédio do desejo deste, de fazer parte de uma nação com esta 'qualidade de vida', proposta, nas fotos, pela publicidade da BASF. Quando o leitor reconhece um símbolo de algo que ele gostaria de ser e do qual gostaria de fazer parte, tem-se uma imagem mitologizada. Por isso, no Brasil, a necessidade do uso 
do arquétipo da Grande Mãe, que mantém em paz o seu lar, e o uso de elementos heráldicos, monopólio do estado, que teria também essa função.

Esse discurso híbrido de patriotismo, paz social e qualidade de vida, dentro de uma comunidade, na qual os acordos - aos quais fazem menção Aglietta (1990) e Girardi (1990) - que mantém a paz social, estão fragilizados, e onde se ouve, em todos os momentos, detalhes sobre uma violência desordenada à qual essa comunidade está exposta, com certeza angaria empatia imediata.

As causas para esse 'esgarçamento' do tecido social e destruição ambiental são naturalizadas, não aparecem como resultados de ações humanas ou de decisões políticas e ambientais errôneas. Simplesmente são mitologizadas como sendo naturais.

Sabe-se, muito bem, que não é proposta da publicidade a discussão das causas desses fatos, não é esse o lugar para isso. Porém, no momento em que se opta por colocar essas imagens para veicular esses sentidos, há um processo de construção de uma realidade. Em nenhum dos anúncios, mentiras são criadas, apenas, opta-se por criar mundos, nos quais os problemas detectados são simplificados e controlados 'assepticamente', em função de uma conclusão, e nos quais os envolvidos na narrativa publicitária - a imagem da BASF e de seus interlocutores - são levados a aceitar como lugar de identificação o que lhes é estipulado.

No Brasil o espaço para o interlocutor é a espera pela restauração da paz social e ambiental, fornecida por figuras arquetípicas maternais ou de estrutura patriarcais.

A BASF focaliza suas narrativas no que diz respeito a sua importância no nível macro, tanto no Brasil como na Alemanha. Chama a atenção para a atuação da empresa na pesquisa, na construção do mundo em função de melhorar a qualidade de vida humana. Com isso constrói para si, no grosso, os mesmos ethé nos dois países. Porém, algumas diferenças são detectadas. Na Alemanha surge o ethos de solidariedade, característica de uma sociedade mais igualitária, no Brasil, onde os problemas sociais são mais agudos, surge o ethos de humanidade, 
deixando a indicação de um comportamento paternalista em relação aos beneficiados pela BASF.

A forma utilizada para a construção desses ethé diferenciados é a escolha, na Alemanha, da figura arquetípica do Grande Pai e do herói e, no Brasil, da Grande Mãe e da prole a ser cuidada, direcionada. Para isso escolhe-se o uso de imagens, expressões fraseológicas e termos que evoquem os respectivos scripts em cada país, como já foi discutido. Na Alemanha: 'Wind und Wetter'/'vento e tempestade', Kälte und Nässe'/'frio e humidade', 'Was gute Bergseile ausmacht', 'Experte', 'Performance', 'strapazierfähig'/'resistente', 'reissfest'/'resistente', 'Unsere Lösungen leisten...'/'nossas soluções produzem...', ...können sich sehen lassen'/'podem ser vistas', 'höhere Qualitäten', 'optmierte Prozesse', 'das Leben anvertrauen'/confiar a vida' etc.

No Brasil: 'faz parte' do 'dia-a-dia', '...você nem percebe', 'inovação e cuidado', 'alimentação', 'nutrição humana', 'qualidade em sua mesa', 'família', 'brinquedo', 'responsabilidade social', 'dentro e fora da sua janela', 'educação', 'jovens de baixa renda' etc. Assim como usam-se termos que impressionam pela carga de cientificidade, como 'ecoeficiência aplicada' etc.

$O$ arquétipo do Grande Pai, ao qual a BASF procura se ancorar no espaço mental dos leitores de língua alemã. Aparenta esperar dos possíveis usuários de seus produtos um comportamento audacioso, corajoso. A BASF traz para si o papel de 'mentor', cujo conhecimento esotérico será traduzido na tecnologia oferecida ao herói. Existe aí, por parte da BASF, um ethos de solidariedade, de ajuda entre indivíduos em situações semelhantes. Essa atitude é mais apropriada à história de conquistas. Está mais de acordo com a história dos europeus, com o histórico das colonizações.

Já no Brasil, com o uso bem acentuado do arquétipo da Grande Mãe, a BASF busca ancorar-se no espaço mental de seus leitores de uma forma bem diversa. Parece querer tranqüilizar os consumidores quanto aos problemas detectados na sociedade e que podem ser percebidos, sutilmente, nos anúncios. Ocupa o lugar de organizador de uma sociedade que ainda 'engatinha', no plano 
da civilização, e que necessita da ajuda, de uma figura que sirva de modelo e cuide da sociedade ao mesmo tempo.

Tais argumentações, lá e cá, ecoam a partir de uma visão de que os europeus seriam os pioneiros, os conquistadores de novas terras e novos povos. Estes, por sua vez, não passariam de comunidades nativas a serem exploradas e protegidas na sua ingenuidade. Continua-se utilizando a visão do papel histórico dos colonizadores frente aos colonizados. São os primeiros que fornecem, enfim, as soluções ideais que os últimos não conseguem ver sozinhos. São eles, os europeus, que trariam os benefícios da civilização.

Para reforçar a construção desses sentidos, é transferido para dentro do anúncio um discurso visualmente bem marcado, porém povoado de elementos subliminares de patriotismo, voltados para induzir a posição da BASF como sendo, juntamente com o Estado, a responsável pela manutenção da coesão social. Por isso o leitor brasileiro tem que ser representado no anúncio como um ser passivo na recepção das soluções encontradas pela BASF para seus (dele) problemas. É muito clara a criação de um ethos de humanidade para marcar o relacionamento entre os consumidores brasileiros e a BASF. Não existe, aí, um relacionamento entre semelhantes.

Os argumentos desenvolvidos pelos anúncios da BASF brasileira assemelham-se aos argumentos usados em discursos autoritários, nos quais os interlocutores não são vistos como indivíduos adultos, capazes de perceber as relações econômicas, sociais, políticas, por si próprio. Tampouco se espera que sejam atores de mudanças que vêm por intermédio de exigências e discussões desenvolvidas em um debate dentro de um espaço político e social. Não existe espaço, nos anúncios da BASF brasileira, para elementos que demonstrem uma força energética, nem individual nem coletiva, capaz de mudar situações indesejadas.

Ao se comparar os dois grupos de anúncios, o uso do elemento arquetípico da Grande Mãe nos anúncios brasileiros realça o uso dos outros elementos arquetípicos usados nos anúncios alemães: o par complementar Grande Pai e o complemento deste, o Herói. O primeiro, praticamente, obriga o segundo a seguir 
o seu caminho e este herói, tampouco, tem a possibilidade de fugir ao que deve ser feito, mesmo que isso lhe custe a vida.

O que se percebe é que este, também, é um discurso autoritário, no qual os leitores vêem-se representados com poucas formas de opções quanto aos papéis com os quais podem se identificar. Ao mesmo tempo, são como que condicionados a ficar repetindo um comportamento determinado por uma sociedade que seria patriarcal que prezaria o heroísmo e a coragem individual, acima da própria vida.

Dentro desse contexto, pode-se entender a frase de Brecht: "Pobre do país que necessita de herói." O que está sendo cultivado acima, na campanha da BASF alemã, é que se espera do elemento masculino que ele seja responsável, por intermédio de seus recursos individuais como coragem e heroísmo, por soluções para situações produzidas dentro de um contexto que ele não pode controlar individualmente.

Portanto, nos dois países, o modelo de argumentação usada é autoritário. Trata-se de um monólogo que deixa poucas alternativas para os indivíduos e os conduz a se identificarem com modelos de atuação social, que indicam caminhos dos quais não se pode escapar. No Brasil, o modelo de vida fica restrito aos círculos familiares, protegidos do perigo com o alto custo de não poder interferir no seu destino coletivo. Na Alemanha, o modelo de vida cultiva a solidão e, ao mesmo tempo realça o perigo para o qual é conduzido, fatidicamente, o herói.

Quanto a este último modelo, apresentado pela BASF alemã, é interessante fazer um paralelo com a publicidade "Du bist das Wunder Von Deutschland"/ "Você é o milagre da Alemanha", veiculada na mídia alemã de setembro de 2005 a janeiro de 2006, e analisada por Holly (2006). Nesta análise, o autor deixa claro que, coincidentemente, uma das funções dessa campanha publicitária também foi chamar a atenção dos cidadãos alemães para começarem a ser responsáveis por seu próprio sucesso, para que saiam da posição de dependentes do estado alemão e comecem a criar soluções individuais para o seu sucesso e bem-estar.

Este autor ainda chama a atenção para o fato de que faz parte do imaginário alemão (Erinnerungsort) o script de rendimento pelo trabalho, e que 
este é acionado pelo script de esporte nas publicidades. É o mesmo gancho cognitivo acionado nos dois primeiros anúncios da BASF.

No início deste trabalho, pensou-se em fazer análises comparativas de publicidades de cervejas nos dois países. Isso serviria para demonstrar de que forma os anúncios brasileiros dessa bebida fazem uso da figura feminina, com o intuito de veicular os seus produtos. Embora haja algumas marcas de cervejas, tais como a Bohemia, que veiculam seus produtos usando motivos semelhantes aos utilizados pelos produtores alemães, a grande maioria das fábricas de cerveja brasileiras usa figuras femininas para isso.

As peças publicitárias alemães serviriam, por outro lado, para demonstrar que os publicitários alemães seriam menos desrespeitosos e usariam outros tipos de motivos como a pureza da natureza, da água, dos produtos utilizados na confecção da bebida etc. Essa foi uma das hipóteses iniciais. Não seria difícil chegar à conclusão de que as publicidades brasileiras de cervejas colocam a figura feminina à disposição do consumidor da mesma forma que a bebida.

Porém, com a coleta de material, percebeu-se que havia outras formas, mais veladas, de usar a figura feminina, sem a necessidade de expô-la da maneira como se faz em anúncios de cerveja brasileira. Partiu-se, então para a análise de anúncios de outros produtos, nos quais essa diferença de abordagem não fosse demonstrada de maneira tão explícita.

Esperava-se que o tratamento dado à figura feminina, nos anúncios alemães, estivesse mais de acordo com as mudanças ocorridas na sociedade, nos últimos decênios. Isto é, esperava-se que sua representação, nas peças publicitárias, estivesse menos condicionada ao seu milenar papel feminino, à disposição do elemento masculino e, portanto, aparecesse menos ligada ao seu tradicional papel de reprodutora e, sim, mais ligada a elementos que indicassem sua participação ativa na sociedade.

Durante as análises dos anúncios alemães, tanto da BASF como da Pfizer, nesse trabalho, a figura feminina não saiu tão ilesa quanto era esperado. $O$ que foi analisado no terceiro anúncio da BASF alemã demonstra que o machismo nas publicidades alemãs, definitivamente, existe, porém deve permanecer no nível 
mais inconsciente, porque já não seria tão aceito como sendo algo que possa ser demonstrado abertamente. Não é algo que possa se apresentar, claramente, como nos anúncios brasileiros de cerveja.

Porém, o papel que cabe à mulher, nos anúncios analisados, continua restrito ao espaço que Ihe foi destinado há milênios: o espaço doméstico, controlado por forças falocráticas, que a mantém em seu 'devido lugar', em compasso de espera. Para evocar esse 'devido lugar' e comportamento lança-se mão de expressões fraseológicas e composições visuais bem elaboradas, de forma que esses scripts sejam evocados inconscientemente e, portanto, não provoquem questionamentos.

Na publicidade da BASF brasileira, tanto a figura masculina como feminina têm papéis semelhantes. Ambas com lugares de identificação com figuras provedoras e protetoras dos círculos familiares. Em todas as publicidades analisadas, anterior e posteriormente ao ano de 2005 (VEJA, 11/07/2003, 11/06/2003), a figura feminina também aparece em seu papel de procriadora, provedora e protetora. Não se vê a mulher em seu papel de donzela disponível.

Nos anúncios de 2005, embora a mulher não apareça claramente nas fotos, o arquétipo da Grande Mãe fica claro. Este é o responsável pela coesão e felicidade da família. Tanto que, no segundo anúncio da BASF brasileira, o aspecto que é recortado da figura masculina é o seu papel de protetor da prole, característica tida como feminina. Não há papel de herói para aquele homem. Nem há papel fora da atividade familiar.

Dentro dessa argumentação autoritária, pode ser entendido o fato dos produtores do anúncio trazerem, de maneira tão subliminar, o discurso patriótico. Esse vínculo autoritário, inquestionável, de uma sociedade patriarcal que exige de seus componentes qualquer sacrifício em nome do que chamam pátria e, ao mesmo tempo, fornece ou tenta fornecer a sensação de pertencença a uma comunidade ou grupo.

A aceitação desse discurso patriótico, por parte dos interlocutores alemães, é improvável, por conta de ter sido um discurso utilizado 'ad nauseam' pelos oficiais nazistas, durante a Segunda Guerra. 
A inclusão dos leitores alemães, como fazendo parte de uma comunidade coesa, dá-se por intermédio do uso do 'nós monolítico', que não deixa ninguém de fora no anúncio. Todos devem sentir-se incluídos nessa grande família BASF.

Além disso, a construção dos anúncios, buscando a empatia dos leitores com o discurso do heroísmo, comprovou-se, ainda, vantajosa, apesar de este discurso ter sido muito utilizado durante a guerra. Basta lembrar um dos últimos discursos de Hermann Göring, dirigido aos soldados alemães, durante o cerco de Stalingrado.

Conhecemos uma poderosa canção de heróis, sobre uma luta sem igual. Chama-se a 'Luta dos Nibelungos'. Também eles estiveram em uma sala, cercados por fogo e chamas, mataram a sede com o próprio sangue, mas lutaram até o último homem (BLUMENTHAL, 2002, p. 52). ${ }^{30}$

Ele usa o trecho final da saga alemã "O Anel dos Nibelungos", na qual os heróis burgundos lutam até o final. Este é, com certeza, um dos exemplos mais dramáticos do uso dessa ideologia de heroísmo, com a função de mandar homens para a morte. Nota-se nessa saga a impossibilidade, na qual se encontram todos os personagens, de escapar ao seu fatídico destino

Não é difícil perceber que a Pfizer alemã cultua, em seus anúncios, os mesmos elementos mitológicos que a BASF, dando uma acentuação maior à figura do herói. Parece bater na mesma tecla a fim de conseguir a empatia dos consumidores/leitores alemães.

Seria interessante a realização de uma pesquisa em que se procurasse identificar a ocorrência desse tipo de herói nas peças publicitárias brasileiras. De memória podemos recordar, isto sim, o uso de anti-heróis, como o 'baixinho' da Kaiser, o garoto da Bom Bril, Arakém, o 'show-mém', usado pela Rede Globo durante a copa do mundo de 1998 e retirado de circulação quando o Brasil foi

\footnotetext{
30 "Wir kennen ein gewaltiges Heldenlied von einem Kampf ohnegleichen. Es heist $>$ Kampf der Nibelungen<. Auch sie standen in einer Halle voll Feuer und Brand, löschten den Durst mit dem eigenen Blut, aber sie kämpften bis zum Letzten."
} 
derrotado etc. Como se, sistematicamente, pretendesse evocar alguns típicos anti-heróis nacionais, como Macunaíma, João Grilo, Trupizupi, entre outros.

Em relação à forma de abordagem, a Pfizer faz com o público ao qual se dirige, no Brasil e na Alemanha, o mesmo que a BASF. Por intermédio de uma exaustiva repetição de construções visuais baseada em arquétipos que trabalham com a sexualidade, procura atuar no leitor de maneira inconsciente, acordando o desejo e minando a rejeição à aceitação, à discussão e, posteriormente ao possível uso do medicamento. Às vezes, como no caso da Pfizer alemã, ocorre a repetição, durante anos do mesmo anúncio, o que é forte sinal de que aquela peça publicitária foi bem sucedida, isto é, angariou a empatia do público e foi eficaz.

Diferentemente da publicidade alemã, nos anúncios brasileiros, mais uma vez, não há espaço para a figura viril do herói, pelo contrário, o elemento masculino brasileiro é esboçado como um ser dependente, psicologicamente, do companheirismo da figura feminina. Isto é mostrado, bem claramente, nos lugares comuns, tanto lingüísticos como visuais, escolhidos para construir as duas peças publicitárias. Daí pode-se deduzir que, novamente, as campanhas publicitárias, na Alemanha e no Brasil, partem de acordos diferentes para atingir seu público alvo.

Ao leitor brasileiro que eventualmente sofra de disfunção erétil, é destinado um lugar aconchegante, tranqüilo, no qual ele é protegido pela presença de uma figura feminina participativa e solidária, que divide com ele o ônus da impotência masculina. A ela é destinado o lugar histórico de ente compreensivo, abnegado e fatalista. Discurso este pregado, inclusive, nas cerimônias de casamento, onde se reforça a idéia de união eterna, seja qual for o problema. Desta forma, procura-se incluir a mulher na responsabilidade da construção de uma união feliz, na qual a figura masculina não representa o elo mais forte, mas um dos elos que compõe a indissolubilidade do casal. Nota-se que o recorte e o realce da figura feminina não é o da mulher sexualizada, mas maternal, que faz de tudo para manter intacto o núcleo familiar. E o recorte da figura masculina é o do ser humano que não deve ser estressado ao ser exposto, sozinho, às dificuldades ocasionadas pelo problema. Há que se ter cuidado. Nada menos heróico. 
Ao leitor alemão, como já foi visto nos anúncios da BASF, a Pfizer continua acentuando o papel heróico e solitário masculino e o papel passivo do feminino, que, inclusive, continua à disposição do masculino. Se num primeiro momento, o feminino aparece de maneira autônoma, buscando apenas o seu prazer, numa segunda leitura sua figura é demonstrada como descomprometida da figura masculina, sem preocupações com atitudes solidárias, o que acentua a solidão e a tarefa do herói em seu papel de satisfazê-la.

O que aparece de forma semelhante na publicidade da Pfizer nos dois países é a escolha cuidadosa de vocábulos, assim como o silenciamento justamente do que se anuncia, já que se trata de um tema embaraçoso para o público em geral e para os homens em particular. Na esfera da intimidade sexual, os dois públicos são abordados pelo silêncio do que se diz. Não está na ordem do discurso falar claramente sobre impotência. Isso coloca em questionamento, de maneira perigosa, para a face dos leitores, uma das identidades masculinas, que é sua potência, sua atividade sexual.

Esse silenciamento deve ser contornado pela introdução de figuras viris, que não lembrem o problema, ou por um texto ou um 'depoimento' de um personagem famoso, como Nando Reis ou Pelé, que já apareceu nos primeiros anúncios do Viagra. Estes funcionariam como figuras de autoridade, de forma a colocar o problema sem falar sobre ele e encorajar as pessoas a tomar uma atitude, isto é, usar o medicamento. Essa estratégia é um bom exemplo de preservação de face do consumidor e da empresa, que se esconde atrás desse índice de autoridade.

A comparação da forma de tratamento da figura feminina e masculina em publicidades alemãs e brasileiras também é um campo de análise a ser perseguido. Não apenas investigando se as mulheres e os homens aparecem, estatisticamente, mais ou menos, para anunciar quais produtos, mas quais aspectos de suas funções em sociedade são recortados, filtrados e realçados. Em quais recortes dos elementos mitológicos eles se apóiam de modo a fundamentar essas narrativas. Isto é, de que forma a argumentação que realça esses aspectos 
é feita de maneira mais explícita ou de forma velada, submersa em um jogo de imagens inconscientes, tanto visual como lingüística.

Outro trabalho interessante seria a pesquisa comparativa sobre o tipo de argumentação construída ao longo tempo, desde a introdução do medicamento Viagra no mercado. Que tipo de sexualidade masculina era mostrada nos primeiros anúncios dos dois países, o que podia ser dito a esse respeito, como era dito e o que foi mudando, na medida em que outras pesquisas foram sendo feitas e assimiladas pelo discurso publicitário.

Com esse trabalho pretendemos contribuir para o aprofundamento do estudo das semelhanças e diferenças das linguagens publicitárias utilizadas em dois países tão diversos como o Brasil e a Alemanha. Para isso foram escolhidas campanhas publicitárias das mesmas empresas, veiculadas nos meios de comunicação dos dois países. O mais surpreendente ao longo deste trabalho de pesquisa foi a descoberta de como as diferenças culturais dos dois países se refletem tanto na linguagem publicitária como na escolha de mitos, arquétipos e símbolos. As abordagens, apesar de se referirem à mesma empresa (BASF) e ao mesmo produto (Viagra), variaram sensivelmente, num e noutro país.

Fim. 


\section{REFERÊNCIAS BIBLIOGRÁFICAS}

AGLIETTA, M. \& ORLÉAN, A. (1990). A Violência da Moeda. Trad. T.S. Tomazini. São Paulo: Brasiliense.

ANTOS, G. (1997). Texte als Konstituitionsformen von Wissen: Thesen zu einer evolutionstheoretischen Begründung der Textlinguistik. In: ANTOS, G.; TIETZ, H. (Hgg.) Die Zukunft der Textlinguistik: Traditionen, Transformationen, Trends. Tübingen: Max Niemeyer Verlag, p.43-64.

ARISTÓTELES (1983). Tópicos: dos Argumentos Sofísticos. 2. ed. Trad. L. Vallandro e G. Bornheim. Versão inglesa de: W.A, Pickard. São Paulo: Abril Cultural.

ARISTÓTELES (s/d). Arte Retórica e Arte Poética. Trad. A. Pinto de Carvalho. Rio de Janeiro: Ediouro.

BACCEGA, M. A. (1998). Comunicação e Linguagem: discursos e ciência. São Paulo: Moderna.

BALHAR, S. et alii (2004). Pons Grosswörterbuch: Deutsch als Fremdsprache. Stuttgart: Klett.

BAKHTIN M. (1995). Marxismo e filosofia da Linguagem. 7. ed. Trad. M. Lahud, Y.F.Vieira. São Paulo: Ed HUCITEC.

(2000). Estética da Criação Verbal. 3. ed. Trad. M. E. Galvão. Versão Francesa. São Paulo: Martins Fontes.

BARQUETA, C. (1999). A Recriação Histórico-Discursiva da Segunda Guerra Mundial. Recife, 141f. Dissertação (Mestrado em Letras e Lingüística) - Centro de Artes e comunicação, Universidade Federal de Pernambuco.

BARTHES, R. (2003). Mitologias. Trad. R. Buongermino, et al. Rio de Janeiro DIFEL.

BAUDRILLARD, J (2000). Significação da Publicidade. In: LIMA, L Costa (Org.). Teoria da Cultura de Massa. 6ed. São Paulo: Paz e Terra.

(2004). O Sistema dos Objetos. 4. ed. Trad. Z. R. Tavares. São Paulo: Perspectiva.

BEAUGRANDE, R. De. (1997). New Foundations for a Science of text and Discourse: cognition, communication, and the freedom of access to knowledge and society. New Jersey: Ablex Publishing Corporation. 
BERGER, J. et al. (1972). Modos de Ver. Trad. A.M. Alves. Lisboa: Edições 70.

BIMMEL, Peter. (1993). Lenrstrategien im Deutschunterricht. Fremdsprache Deutsch, Stuttgart: Klett Verlag n.1/1993 v.8, p.4-11.

BLIKSTEIN, E. (1985). Kasper Hauser ou A Fabricação da Realidade. 2.ed. São Paulo: Cultrix.

BOLEN, J. S. (2205). As Deusas e a Mulher: nova psicologia das mulheres. 7.ed. Trad. M. L. Remédio. São Paulo: Paulus.

BOURDIEU, P. (1996). A Economia de Trocas Lingüísticas. Trad. S.Miceli et al. São Paulo: Ed. Universidade de São Paulo.

(1998). Contrafogos: táticas para enfrentar a invasão neoliberal. Trad.: L. Magalhães. Rio de Janeiro: Jorge Zahar Ed.

BRANDÃO, J. S. (1993). Milologia Grega. 5.ed. Petrópolis: Vozes, vol.III.

BRANDÃO, M. H. N. (1991). A Constituição da Subjetividade o Discurso da Propaganda. D.E.L.T.A., Campinas. vol. 7, n.2. p. 449-462.

BROCKHAUS, F. A. (1974). Der Sprach Brockhaus. Wiesbaden: Brockhaus.

BROWN, J. A. C. (1971). Técnicas de Persuasão. Da Propaganda à Lavagem Cerebral. 2. ed. Trad. A. Alves Velho. Rio de Janeiro: Zahar Ed.

BUCCI,E; KEHL, M. (2004). Videologias: ensaios sobre televisão. São Paulo: Boitempo.

BURGER, H. (1998); Pfraseologie. Eine Einführung am Beispiel des Deutschen. Berlin: Erich Schmit Verlag.

BURKE, P. (2002). A Esfera Pública 40 anos depois. Folha de São Paulo, São Paulo, 24 março 2002. Caderno Mais, p13-14

CAMPBELL, J (1997). O Herói de Mil faces. Trad. A.U.Sobral. São Paulo: Cultrix.

CAMPBELL, J; MOYERS, B. (2002). O Poder dos Mitos. 20.ed. Trad. C. F. Moisés. São Paulo: Palas Athena.

CARVALHO, Nelly. (2003). Publicidade: A linguagem da sedução. 3.ed. São Paulo: Atica. $\overline{2004}$, p. 11.

(2004). Propaganda ou Publicidade. Jornal do Commercio. Recife, 12 nov. 
p.11.

(2006). Formação do Leitor. Jornal do Commercio. Recife, 28 abril, 2006,

CHARAUdEAU, P. (2006). Discurso Político. Trad. F. Komesu; D. F. da Cruz. São Paulo: Contexto.

CITELLI, A. (1995). Linguagem e Persuasão. 10. ed. São Paulo: Atica.

CIRLOT, J. E. (1985) Diccionario de Símbolos. 6.ed. Barcelona: Editorial Labor.

COELHO, C. P. N. (2003). Publicidade: É possível escapar?. São Paulo: Paulus.

CORRASCOZA, J. A. (sd). A Evolução do texto publicitário. 5. ed. São Paulo: ED Futura.

CUNHA, C. (1976). Gramática do Português Moderno. 6.ed. Belo Horizonte: Ed. Bernardo Álvares S.A.

DINNEEN, F. (1966). General Linguistik. New York: Holt, Rinehart and Winston, INC.

DIZARD Jr., W. (2000). A Nova Mídia: a comunicação de massa na era da informação. Trad. Jorge Edmond. Rio de Janeiro: Zahar.

DONDIS, D. A. (2003). Sintaxe da Linguagem Visual. 2.ed. São Paulo: Martins Fontes.

DOSTOIEVSKI, Fiodor M. (2000). O Jogador. São Paulo: Martin Claret.

DUBOIS, J. et alii (1995). Dicionário de Lingüística. 5.ed. Trad. F. P. Barros et alii. São Paulo: Cultrix.

DUCROT, Oswald (1987). O Dizer e o Dito. Trad. E Guimarães. Campinas: Pontes.

EAGELTON, Terry (1997). Ideologia: Uma Introdução. Trad. S.Vieira, S., L. Borges. São Paulo: Ed da Universidade Paulista/Boitempo.

ECO, U. (1976). A Estrutura Ausente. 3. ed. Trad. F.S. Cantarelli. São Paulo: Perspectiva.

FAIRCLOUGH, Norman. (1990). Language and Power. 2ed. Singapore: Longman Group Ltd.

(1995). Critical Discourse Analisys: papers in the critical study of language. Singapore: Longaman Group Limited 
(2001). Discurso e Mudança Social. Trad. I. Magalhães. Brasília: Ed Universidade de Brasília.

Routledge.

(2003). Analysing Discourse: Textual analysis for social research. London:

FAIRCLOUGH, N.; CHOULIARAKI, L. (1999). Discourse in Late Modernity: rethinking critical discourse analysis. Edinburgh: Edinburgh University Press.

FALCÃO FILHO, J. de A. (2001). A Propaganda Institucional: Usos Léxicos nas Estruturas de Argumentação Discursiva. 145f. Dissertação (Mestrado em Letras e Lingüística) - Centro de Artes e comunicação, Universidade Federal de Pernambuco.

FIX, Ulla. (1997). Kanon und Auflösung des Kanons. Typologische Intertextualität ein "posmodernes" Stilmittel? In: ANTOS, G.; TIETZ, H. (Hggs) Die Zukunft der Textlinguistik. Tübingen: Max Niemeyer Verlag p.97-108.

FIX, U; POETHE, H; YOS, G. (2003). Texttlinguistik und Stilistik für Einsteiger. Frankfurt a M.: Meter Lang GMBH.

FISCHER, E. (1983). A Necessidade da Arte. Trad. L. Konder. Rio de Janeiro: Zahar.

FLEISCHER, W. (1997). Phraseologie der deutschen Gegenwartsprache. 2.Aufl. Tübingen: Niemeyer.

FOUCAULT, M. (1991). A Arqueologia do Saber. Trad. L.F.B. Neves. Rio de Janeiro: Vozes. Loyola.

(2000). A Ordem do Discurso. 6.ed. Trad. L. F. A. Sampaio. São Paulo: Ed.

FOWLER, R. \& KRESS, G. (1979). Critical Linguistics. In: FOWLER, R et al. (Orgs.). Language And Control. London: Routldge \& Kegan Paul Ltda, p.185-213.

FREUD, S. (1974). Totem e Tabu: alguns pontos de concordância entre a vida mental dos selvagens e dos neuróticos. Trad. O. C. Muniz. Rio de Janeiro: Ed. Imago.

FROMM, E. (1980). Ter Ou Ser. 4. ed. Trad. N.C. Caixeiro. Rio de Janeiro: Zahar Ed.

GILES, T.R. (1993). Dicionário de Filosofia: termos e filósofos. São Paulo: EPU.

GIRARD, R. (1990). A Violência e o Sagrado. 2. ed. Trad. M.C. Gambini. São Paulo: Ed. Universidade Estadual Paulista/Paz e Terra, p. 1-190. 
GLENK, E. M. F. (2000). Die Funktion der Sprichwörter im Text: Eine linguistische Untersuchung anhand von Texten aus Elfriede Jelineks Werken. Wien: Edition Praesens.

GOFFMAN, E. (1965). A Representação do Eu na vida Cotidiana. Petrópolis: vozes.

GOMES, N. D. (2003). Comunicação Persuasiva. Porto Alegre: Ed. Sulinas.

GÖTZ, D. et al. (2002). Langenscheidts Grosswörtebuch Deutsch als Fremdsprache. Berlin, München: Langenscheidt.

GÜLICH, E. (1997). Routinenformeln und Formulierungsroutinen. In: WIMMER, R; BERENS, F.J. (Hg.). (1997). Wortbildungen und Phraseologie. Tübingen, Günter Narr Verlag. P131-175..

GULLAR, F.J.R. (2005). Folha de São Paulo, São Paulo, 16 mar. 2005, p.15.

HABERMAS, J. (1989). Consciência Moral e Agir Comunicativo. Trad. G.A. Almeida. Rio de Janeiro: Tempo Brasileiro.

HARVEY, D. (2004). Condição Pós-Moderna. 13ed. Trad. U.A Sobral; M.S. Gonçalves. São Paulo: Edições Loyola.

HAUG, W F. (1997). Crítica da Estética da Mercadoria. Trad. E. Paschoal. São Paulo: UNESP.

HEINEMANN, W.; VIEHWEGER, D (1991). Textlinguistik: eine Einführung. Tübingen: Max Niemeyer Verlag.

HILLMAN, J. (1989). Entre-Vistas. São Paulo: Summus.

HOLLY, W. (2006). Audiovisuelle Hermeneutik. Am Beispiel des TV-Spots der Kampagne „Du bist Deutschland”. Palestra proferida na ABRABA, São Paulo.

HORKHEIMER, M.; ADORNO, T. W. (2000). A Indústria cultural: O iluminismo como mistificação de massas. In: LIMA, L. Costa (Org.) Teoria da Cultura de Massa. 6. ed. São Paulo: Paz e Terra. p.169-214.

HUBERMAN, L. (1978). História da Riqueza do Homem. 14.ed. Trad. W. Dutra. São Paulo: Zahar Editores.

JANICH, N. (1999). Werbesprache: ein Arbeitsbuch. Tübingen: Narr. 
JAWORSKI, A.; COUPLAND, N. (Orgs.) (2000). The Discourse Reader. London: Routledge. p.1-38.

JOLY, M. (2005). Introdução à Análise da Imagem. 9.ed. Trad. M. Appenzeller. Campinas: Papirus.

JUNG, C. G. (1963) Memórias, Sonhos e Reflexões. Trad. D. Ferreira da Silva. São Paulo: Nova Fronteira. p. 133-195.

(1964). Chegando ao Inconsciente. In: JUNG, C. G.; FRANZ, L. (1964). O Homem e seus Símbolos. 18.ed. Trad. M. L Pinho. Rio de Janeiro: Nova Fronteira. p. 20-103.

(1985). A Prática da Psicoterapia: contribuições ao problema da psicoterapia e à psicologia da transferência. 4.ed. Trad. Mํ. L. Appy. Petrópolis: Vozes.

KENDE, P. (1974). A Publicidade e a Informação do consumidor. In: MARCUSSTEIFF, J. et alii. (Orgs.). Os Mitos da Publicidade. Trad. H.F. Jupiassú. Petrópolis: Vozes. p. 63-78.

KEY, A. B. (1990). A Era da Manipulação. São Paulo: Ed Página Aberta.

KOCH, I.V. \& TRAVAGLIA, L. C. (1991). A Coerência Textual. 2. ed. São Paulo: Contexto.

KOCH, I.V. (1993). A Produção de Inferências e Sua Contribuição na Construção de Mundo. D.E.L.T.A. 9: 399-416. Campinas.

KOCH, I. V. (1995). A Inter-Ação Pela Linguagem. São Paulo: Contexto.

(1996). Argumentação e Linguagem. 4ed. São Paulo: Cortez.

(2004). Introdução à Lingüística Textual. São Paulo: Martins Fontes.

KOCH, I.V. \& MARCUSCHI, L. A. (1998). Processos de Referenciação na Produção Discursiva. IN.: D.E.L.T.A., Vol. 14, N. Especial, 1998. p.169-190.

KRESS, G; VAN LEEUWEN, T. (2001). Reading Images: The Grammar of Visual Design. London: Routledge.

LAVADO, J. (1979). Mafalda. Barcelona: Editorial Lúmen. V. 6.

(1979). Mafalda. Barcelona: Editorial Lúmen. V.7.

LAKOFF, G; JOHNSON, M. (2002). Metáforas da Vida cotidiana. Trad. M. S. Zanotto. Campinas: Mercado das Letras; EDUC 
LIMA, L. Costa. (2000). Comunicação e Cultura de Massa. In: LIMA, L Costa (Org.). (2000). Teoria da Cultura de Massa. 6. ed. São Paulo: Paz e Terra.

LIPPMANN, W. (1972). Estereótipos. In: STEINBERG. C. S. (Org.). Meios de Comunicação de Massa. Trad. O. Mendes Cajado. São Paulo: Cultrix.

LOPES, E. (1977). Fundamentos da Lingüística Contemporânea. 2.ed. São Paulo: Cultrix.

LÜGER, H.H. (1997). Routinen und Ritualien in der Alltagskommunikation. Berlin: Langenscheidt. (Fernstudienprojekt)

MAI, M. (2001). Geschichte der Deutschen Literatur. Basel: Belz Verlag.

MAINGUENEAU, D. (1997). Novas Tendências em Análise do Discurso. 3. ed. Trad. F. Indursky. Campinas/São Paulo: Pontes/Ed Universidade Estadual de Campinas.

MARCUS-STEIFF. J (1994). Mitos da Publicidade. In: MARCUS-STEIFF, J. et alii. (Orgs.). Os Mitos da Publicidade. Trad. H.F. Jupiassú. Petrópolis: Vozes.

MARNY, J. (1970). Sociologia das Histórias aos Quadrinhos. Trad. M.F.M Correia. Porto: Livraria Civilização.

MARSICO, M.T. et alii. (2000). Marcha Criança: história e geografia:

4.série. São Paulo: Scipione.

MARTIN-BARBERO, J. (1998). Prefácio. In: BACCEGA, M. A. (1998). Comunicação e Linguagem: discursos e ciência. São Paulo: Moderna, p3-8.

MARTINS, N. S. (1989). Introdução à Estilística: a expressividade na língua portuguesa. São Paulo: EDUSP.

MATURANA, H. (2002). Emoções e Linguagem na Educação e na Política. Trad. J.F.C. Fortes. Belo Horizonte: Editora UFMG.

MEHAN, H. (1996) The discourse of illegal imigration debate: a case study in the politics of representation. In: Discourse \& Society 8(2): 249-270.

MICHAELIS (1998) Moderno dicionário da língua portuguesa. São Paulo: Melhoramentos.

MONNERAT, R. M. (2003). A Publicidade pelo Avesso. Niterói: EdUFF.

MORIN, E. (1997). Cutura de Massa no Século XX: neurose. 9.ed. trad. M. R. Sardinha. Rio de Janeiro: Forense-Universitária. 
MOURA, H.M.M. (2000). Significação e Contexto: uma introdução a questões de semântica e pragmática. 2.ed. Florianópolis: Insular.

MULLER, W. (1997). Interkulturelle Werbung. Heidelberg: PHysika-Verl.

NEF, F. (1995). A linguagem: uma abordagem filosófica. Trad. Lucy Magalhães. Rio de Janeiro: Zahar Ed.

NEUMANN, U. (2001). Rhetorik. In: ARNOLD, H.L.; DETERING, H. (Hgg). Grundzüge der Literaturwissenschaft. 4. Aufl. München: DTV. S. 219-233.

OLIVEIRA, L. S. P. (1996) Informação ou Propaganda? O que recebemos? O que percebemos? Brasília: Thesaurus.

PÉNINOU, G. (1974). O Sim, o Nome, e o Caráter. In: MARCUS-STEIFF, J. et alii. (Orgs.). Os Mitos da Publicidade. Trad. H.F. Jupiassú. Petrópolis: Vozes.

PERELMAN, C.; OLBRECHTS-TYTECA, L. (2002) Tratado da Argumentação: A Nova Retórica . Trad. Maria E Galvão. São Paulo: Martins Fontes.

PESSANHA, J. A. M. (1983). Vida e Obra. In: ARISTÓTELES (1983). Tópicos: dos Argumentos Sofísticos. 2. ed. Trad. L. Vallandro e G. Bornheim. Versão inglesa de: W.A, Pickard. São Paulo: Abril Cultural, p. VII -XXII.

PINHO, J. Benedito. (1990). Propaganda Institucional: Usos e funções da propaganda em relações públicas. São Paulo: Summus.

POLENZ, P (1985) Deutsche Satzsemantik: Grundbegriffe des Zwischen-den Zeilen-Lesens. Berlin: de Gruyter.

BLUMENTHAL, P.J. (2002). Für Ruhm und Ehre des Vaterslandes. P.M. HISTORY, München, v.6, p. 46-53, Jan. 2002.

PÖRKSEN, U. (1997). Plastikwörter: die Sprache einer internationalen Diktatur. 5. Aufl. Stuttgart: Klett-Cotta.

QUESNEL, L. (1974). A Publicidade e sua Filosofia. In: MARCUS-STEIFF J. et alii. (Orgs.). (1974). Os Mitos da Publicidade. Trad. H. F. Jupiassú. Petrópolis: vozes, p.79-93.

RANDAZZO, S. (1997) A Criação de Mitos na Publicidade. Trad. M. Fondelli. Rio de Janeiro: Rocco.

REBOUL, O. (1975). O Slogan. Trad. Ignácio Assis da Silva. São Paulo: Cultrix. 
RIESMAN, D (2002) O Turno da Noite. In: LIMA, L Costa.(org) Teoria da Cultura de massa. 6. ed. São Paulo: Paz e Terra, P.137-148.

RODRIGUES, A. F. (2005). Como Elaborar Citações e Notas de Rodapé. 2.ed. São Paulo: Associação Editorial Humanitas.

(2005). Como Elaborar Referências Bibliográficas. 4.ed. São Paulo: Associação Editorial Humanitas.

ROCHA, E. Guimarães, (1985). Magia e Capitalismo: Um estudo antropológico da Publicidade. São Paulo: Brasiliense.

SANDMANN, A. J. (1993). A Linguagem da Propaganda. São Paulo: Contexto.

SAUSSURE, F. (1977). Curso de Lingüística Geral. 8. ed. Trad. A. Chelini et al. São Paulo: Cultrix.

SOWINSKY, B. (1988). Deutsche Stilistik: Beobachtung zur Sprachverwendung und Sprachgestaltung im Deutschen. Frankfurt a. Main: Fischer Verlag.

SPANG, K. (1987). Grundlagen der Literatur und Werberhetorik. Kassel: Edition Reichenberger.

TAGNIN, O.S. (1989). Expressões Idiomáticas e Convencionais. São Paulo: Editora Ática.

TOLSTOI, L. (1984). Ana Karenina. Trad. J.G. Simões. São Paulo: Círculo do Livro S.A.

TOMASELLO, M (2003). Origens Culturais da Aquisição do Conhecimento Humano. Trad. C. Berliner. São Paulo: Martins Fontes.

VAN DIJK, T. A. (1992). Discurso de Elite e Reprodução do Racismo. In: D.E.L.T.A. 8:1-36.

(1993). Principles of crictical discourse analyses. In: Discouse\&Society: 8(2): 249-283.

(1996). Cognição, Discurso e Interação. Trad. I.V. Koch 2. ed. São Paulo: Ed. Contexto.

(1997). Discourse, Power and Access. Program of Discourse Studies. University of Amsterdan (Mimeo)

VANOYE, F. (1993). Usos da Linguagem: problemas e técnicas na produção oral e escrita. Trad. C.M. Sabóia; et al. 9. ed. São Paulo: Martins Fontes 
VESTER, F. (1986). Denken, Lernen, Vergessen: was geht in unserem Kopf vor, wie lernt das Gehirn, und wann lässt es uns im Stich? 13. Auf. Stuttgart: DTV Verlag.

VESTERGAARD, T.; SCHROEDER, K. (2000). A linguagem da propaganda. 3. ed. Trad. João Alves dos Santos; Trad. dos textos publicitários Gilson C.C. Santos. São Paulo: Martins fontes.

VIGOTSKY, L.S. (2001). A Construção do Pensamento e da Linguagem. Trad. Paulo Bezerra. São Paulo: Martins Fontes.

VOGT, Carlos. (1989). Linguagem, Pragmática e Ideologia. 2.ed. São Paulo: HUCITEC.

VOGT, C. \& DUCROT, O. (1989). De magis a mas: uma hipótese semântica. In: VOGT, Carlos. (1989) Linguagem, Pragmática e Ideologia. 2.ed. São Paulo: HUCITEC. p. 103-128.

WAHRIG, G. et alii (1977). Deutsches Wörtebuch. Berlin: Bertelsmann.

WILBER, K. (2001). Uma Breve História do Universo: De Buda a Freud. Trad. Ivone Carvalho. Rio de Janeiro: Novaera.

WITTGENSTEIN, L. (1984). Investigações Filosóficas. 3. ed. Trad. J.C Bruni. São Paulo: Abril Cultural.

WENDT, M. (1993). Medien und Mythen: Texttheoretisch und fremdheitspädagogische Aspekte massenmedialer Wirklichkeitskonstruktion. In: BREDELLA, L.; CHRIST, H. (Hrsg.). (1993). Zugänge zum Fremden. Giessen: Verlag der Ferber'schen Universitätsbuchhandlung, p. 111-134.

ZIELKE, A. (1991). Beispiellos ist beispielhaft. Pfaffenweiler: CentaurusVerlagsgesellschaft. 
ANEXO 1

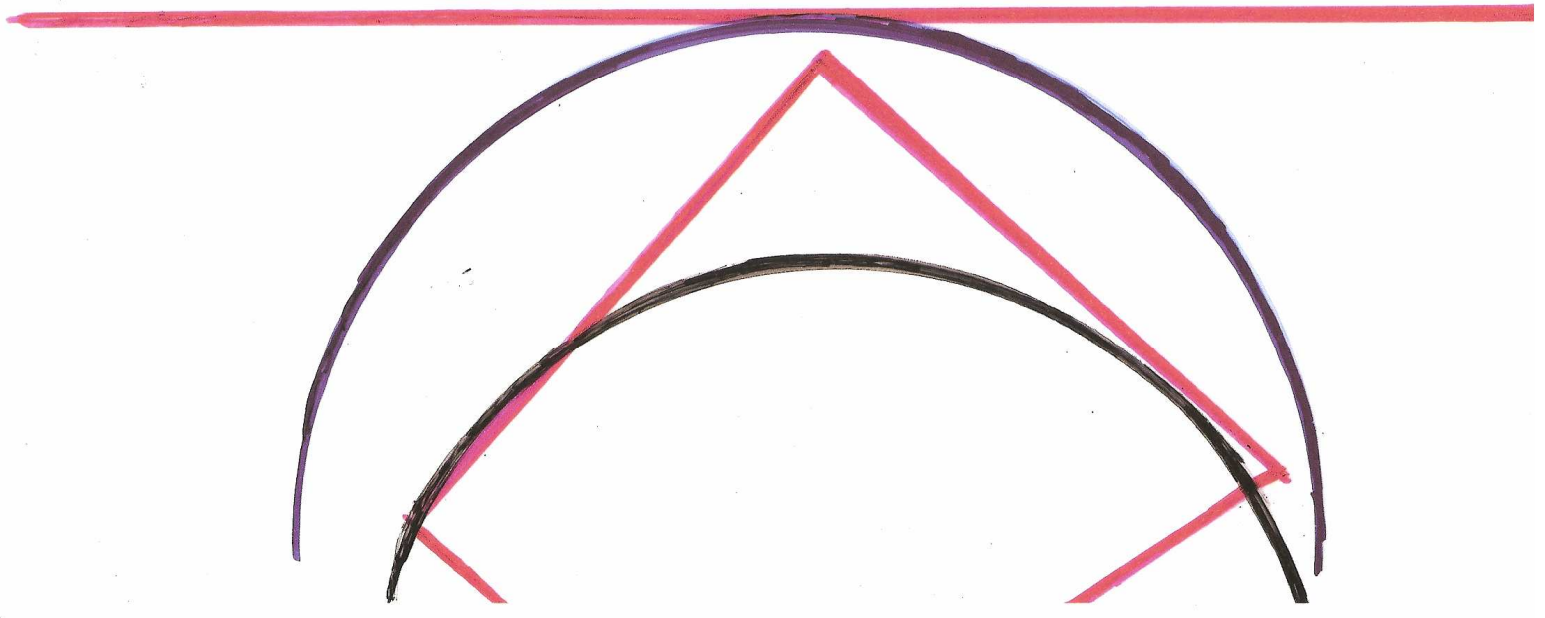


ANEXO 2

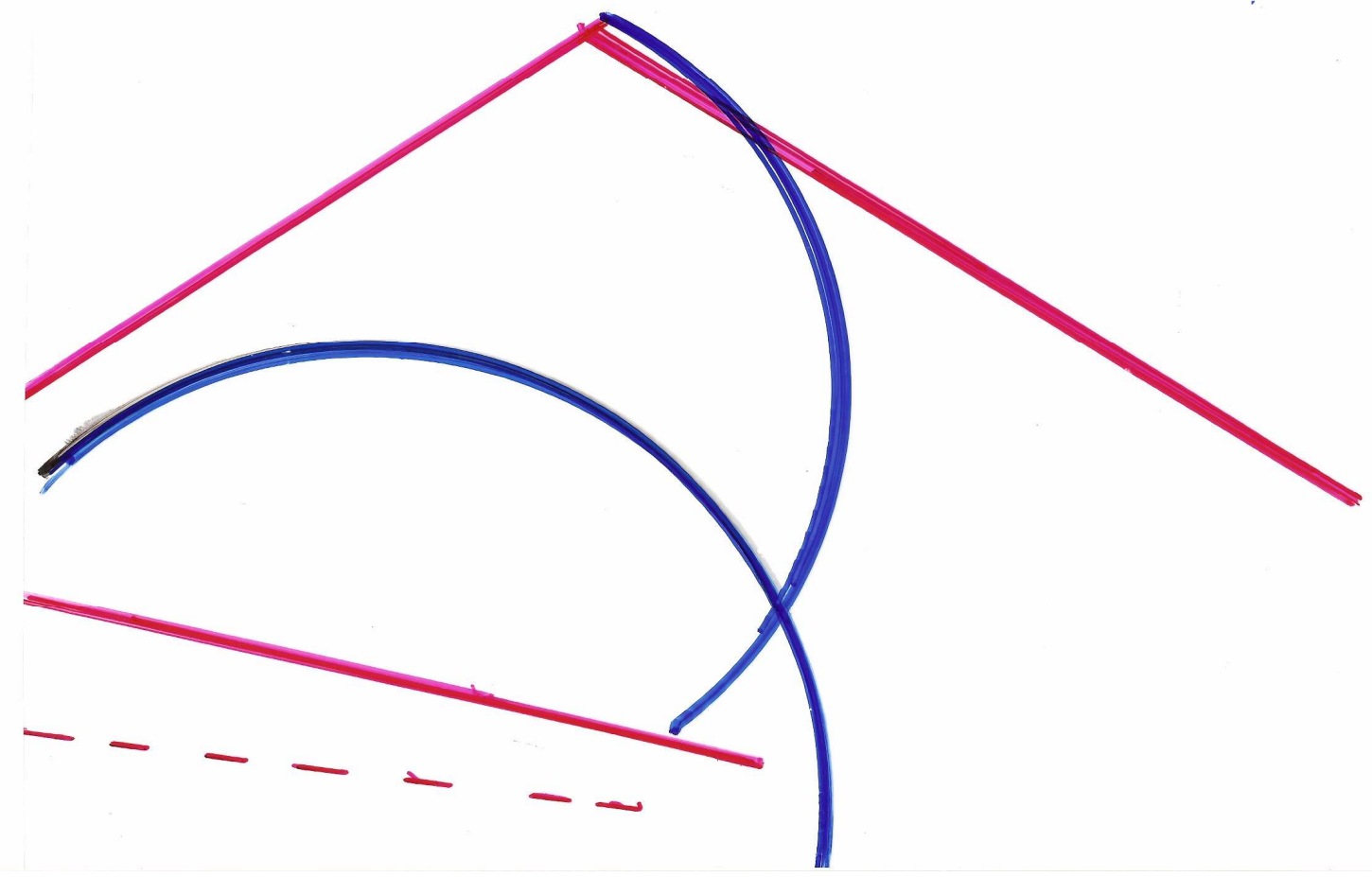


ANEXO 3

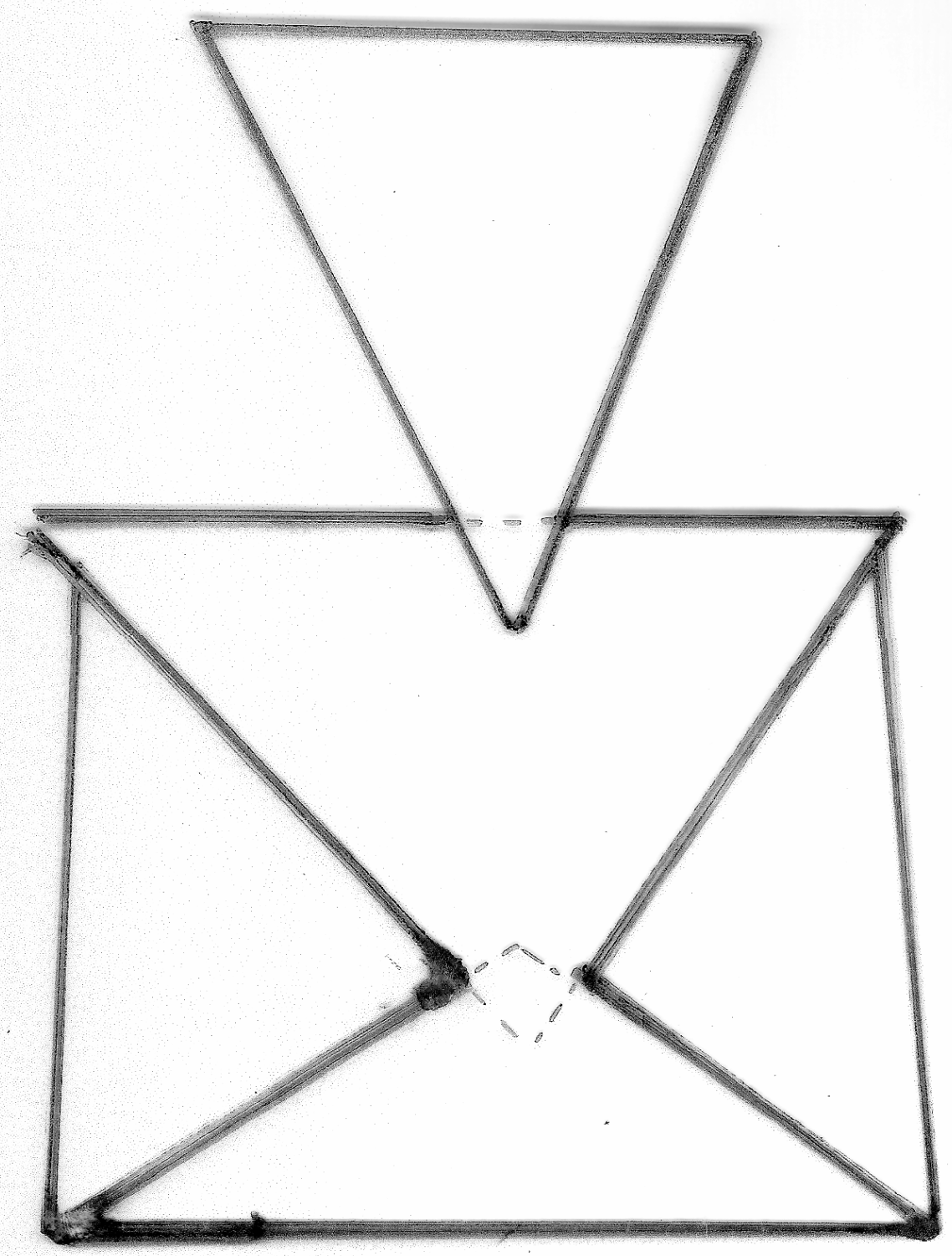




\section{ANEXO 4}

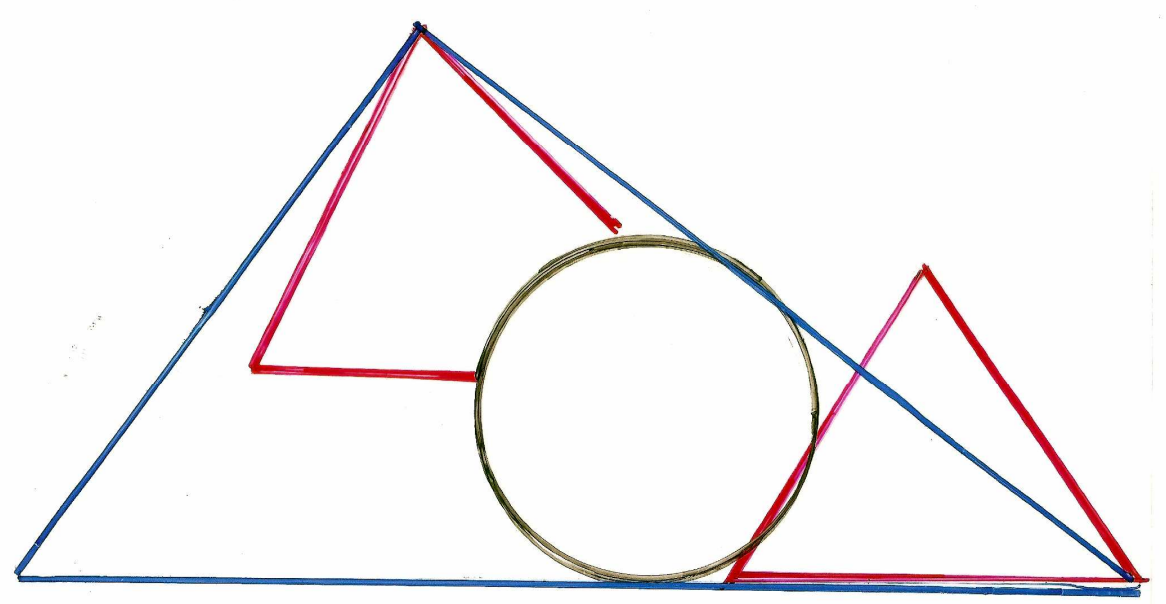

